\author{
UNIVERSIDADE DE SÃO PAULO \\ ESCOLA DE COMUNICAÇÕES E ARTES - ECA
}

VERA DE FÁTIMA VIEIRA

Comunicação e feminismo:

as possibilidades da era digital

São Paulo

2012 


\title{
Comunicação e Feminismo: as possibilidades da era digital
}

\author{
Tese apresentada ao Programa de Pós- \\ Graduação em Ciências da Comunicação \\ (PPGCom) da Escola de Comunicações e \\ Artes da Universidade de São Paulo para a \\ obtenção do título de Doutora em Ciências \\ da Comunicação. \\ Área de Concentração: Interfaces Sociais \\ da Comunicação \\ Linha de Pesquisa: Comunicação, Cultura e \\ Cidadania \\ Orientadora: Prof ${ }^{\mathrm{a}}$. Dr ${ }^{\mathrm{a}}$. Maria Cristina \\ Castilho Costa.
}

São Paulo 
Autorizo a reprodução e divulgação total ou parcial deste trabalho, por qualquer meio convencional ou eletrônico, para fins de estudo e pesquisa, desde que citada a fonte.

\author{
Catálogo da Publicação \\ Serviço de Documentação
}

Escola de Comunicações e Artes da Universidade de São Paulo

Vieira, Vera de Fátima.

Comunicação e Feminismo: as possibilidades da era digital / Vera de Fátima Vieira; orientadora Maria Cristina Castilho Costa. - São Paulo, 2012.

234f.: il.

Tese (Doutorado)-Universidade de São Paulo, 2012.

1. Comunicação. 2. Feminismo. 3. TIC. 4. Internet. 5. Violência doméstica. 6. Gênero. 7. Mulher. 8. ONG. 
Nome: VIEIRA, Vera de Fátima

Título: Comunicação e feminismo: as possibilidades da era digital

Tese apresentada ao Programa de PósGraduação em Ciências da Comunicação (PPGCom) da Escola de Comunicações e Artes da Universidade de São Paulo para a obtenção do título de Doutora em Ciências da Comunicação.

Aprovada em:

Banca Examinadora

Prof $^{a}$. Dra Instituição:

Julgamento: Assinatura:

$\operatorname{Prof}^{\mathrm{a}}$. Dr ${ }^{\mathrm{a}}$. Instituição:

Julgamento: Assinatura:

Prof. Dr. Instituição:

Julgamento: Assinatura: 
Dedico esta tese ao meu pai, Manoel Vieira (in memoriam), eterno incentivador de minhas possibilidades criativas. 


\section{AGRADECIMENTOS}

Esta tese é a concretização de uma etapa desafiadora em meu percurso de vida, tanto em termos de crescimento acadêmico como de solidificação das atividades profissionais, com o entrelaçamento de ambos os campos. A amplitude desta conquista só foi possível graças à dedicação, apoio e carinho de pessoas envolvidas, a quem registro aqui minha gratidão:

À minha orientadora, Profa ${ }^{\text {. Dr }}{ }^{a}$. Maria Cristina Castilho Costa, por se assumir feminista e aceitar o desafio instigante desta trajetória conjunta.

À Coordenação de Aperfeiçoamento de Pessoal de Nível Superior (CAPES).

Aos mestres e às mestras das disciplinas cursadas, que foram fundamentais para o embasamento teórico deste trabalho: Guilhermo Orozco Gómez, Bernard Miege, Jesús-Martin Barbero, Isabel Ferin Cunha, Maria Cristina Castilho Costa, Brasilina Passarelli e Stella Conceição Bertholo Piconez.

A todas as participantes da pesquisa-ação que são integrantes das oito organizações de base escolhidas, mulheres abertas a novos desafios em prol da harmonização das relações sociais de gênero. Agradecimento especial às entidades parceiras, assim como à assistente do projeto Walkíria J. L. Ferraz e às palestrantes e monitoras Nilza Iraci, Jacira Melo, Cacau Freire, Ana Rosa Carrara, Anna Frank, Ana Célia Minuto e Panmela Castro.

Ao Prof. Dr. Adilson Odair Citelli e à Prof ${ }^{a}$. Dr ${ }^{a}$. Heleieth Saffioti (in memoriam), integrantes da banca de qualificação, pelo olhar minucioso e competente, contribuindo para os rumos adequados do trabalho final.

A todos e todas que aceitaram o convite para a lista de componentes da banca final desta tese de doutorado: Prof ${ }^{a}$. Dr ${ }^{a}$. Charmain Levy, Prof. Dr. Luiz Roberto Alves, Prof. Dr. Adilson Odair Citelli, Prof ${ }^{a}$. Dra ${ }^{a}$. Maria Aparecida Baccega, Prof ${ }^{a}$. Dr ${ }^{a}$. Maria Immacolata V. Lopes, Prof ${ }^{a}$. Dr ${ }^{a}$. Roseli Fígaro, Prof ${ }^{a}$. $D r^{a}$. Sílvia Pimentel, Prof ${ }^{a}$. Dra . Eva Blay, Prof ${ }^{a}$. Dr ${ }^{a}$. Maria José Rosado F. Rosado Nunes e Prof. Dr. Gonçalo Guimarães. 


\section{RESUMO}

VIEIRA, V.F. Comunicação e feminismo: as possibilidades da era digital. 2012. 234 f. Tese (Doutorado) - Escola de Comunicações e Artes, Universidade de São Paulo, 2012.

Alicerçada no pressuposto da inter-relação entre os campos da comunicação e do feminismo, esta proposta pretende fornecer subsídios ao movimento de mulheres e feminista, comprovando que as Tecnologias da Informação e Comunicação (TIC) - que têm na internet a sua maior expressão - não são um fim, mas um instrumento para a transformação social. Com a revolução das TIC, o avanço do trabalho pela equidade das relações sociais de gênero depara-se com o desafio da mudança de mentalidade. Concomitantemente com a revolução tecnológica, ocorrem as revoluções do aprendizado e da expressão pessoal e interpessoal, acarretando outras formas de representação da mulher em função das novas dinâmicas comunicacionais. É pela comunicação a distância que se vislumbra um caminho de reformulação da agenda feminista, com novas estratégias de intervenção política e de atuação. 0 recorte da pesquisa foca a implementação do uso da internet mais especificamente das redes sociais - para o avanço da luta contra a violência às mulheres, no âmbito doméstico. Considera-se esta cruel realidade como a mais grave expressão das desigualdades de gênero, as quais foram construídas há milênios, colocando a mulher em condição de subordinação ao homem, o que acarreta prejuízos para toda a sociedade.

Palavras-chave: Comunicação. Feminismo. TIC. Internet. Violência doméstica. Gênero. Mulher. ONG. 


\begin{abstract}
VIEIRA, V.F. Communication and Feminism: possibilities of digital age. 2012. 234 f. Tese (Doutorado) - Escola de Comunicações e Artes, Universidade de São Paulo, 2012.

Based on the assumption of inter-relation between the fields of communication and feminism, this proposal intends to provide subsidies to the women's and feminist movement, proving that Information and Communication Technologies (ICT) - which have in the internet their most significant expression - are not an end, but rather an instrument for social transformation. With the ICT revolution, the advancement of work for equality in social gender relations faces the challenge of a mentality change. Simultaneously with the technological revolution, the revolutions in the areas of learning and personal and interpersonal expression are occurring, bringing forth new forms of representation of women, made possible by the new communicational dynamics. It is through long-distance communication that it is possible to foresee a path for reformulation of the feminist agenda, with new strategies for political intervention and action. The research focuses on the implementation of the use of the internet for the progression of the specific struggle against violence on women, in the domestic sphere, considering this cruel reality as the gravest expression of gender inequalities, built millennia ago, and which places women in a position of subordination to men, causing damages to society as a whole.
\end{abstract}

Keywords: Communication. Feminism. ICT. Internet. Domestic violence. Gender. Woman. NGO. 


\section{SUMÁRIO}

1 INTRODUÇÃO

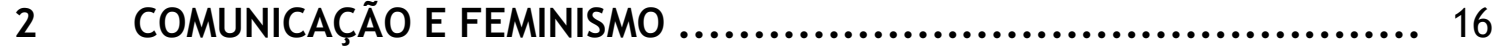

2.1 A mulher nas mídias tradicionais ................................... 19

2.1.1 A mulher no rádio e na TV ........................................... 28

2.2 A mulher nas mídias digitais ......................................... 33

3 AS TEORIAS COMUNICACIONAIS E A EVOLUÇÃO DOS INSTRUMENTOS DE

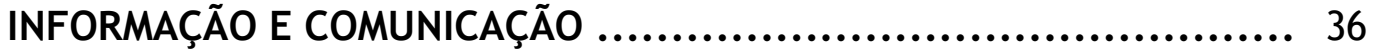

3.1 A construção de um campo científico específico ....................... 38

3.1.1 O modelo das mediações .......................................... 43

3.2 A evolução das mídias tradicionais ................................ 48

3.3 A revolução das mídias digitais ........................................ 56

3.3.1 A interatividade: o maior potencial da internet ...................... 63

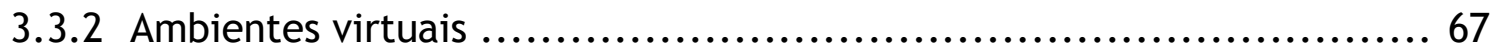

4 AS TEORIAS FEMINISTAS E A VIOLÊNCIA CONTRA A MULHER ........... 72

4.1 Relações de gênero, movimento feminista e movimento de mulheres .. 74

4.1.1 Dois movimentos sociais por um mesmo fim ....................... 80

4.2 A violência contra a mulher, como conseqüência do binômio dominação/ subordinação ............................................................ 87

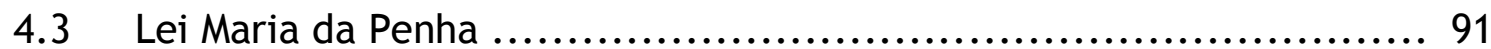

4.4 As raízes da violência contra a mulher ................................. 95

5 A CONSTITUIÇÃO DO IMAGINÁRIO E A REPRESENTAÇÃO DA MULHER NA MÍDIA ........................................................................... 101

5.1 O imaginário na construção do pensamento e de práticas cotidianas .. 103

5.2 O tear e a trama das relações humanas .............................. 110

5.3 A representação da mulher na mídia ............................... 117 
5.4 A violência real e a simbólica ..................................... 124

6 AS POSSIBILIDADES DA ERA DIGITAL ................................. 133

6.1 O pessoal é político: narrativas feministas e sociedade em rede redefinem o conceito de democracia ................................... 135

6.1.1 Uma nova narrativa para o público e o privado ........................ 137

6.2 A pesquisa-ação ....................................................... 139

6.2.1 O objeto de estudo e a justificativa ................................. 143

6.2.2 As etapas da experiência ........................................... 146

6.3. As possibilidades de diferentes dinâmicas de construção simbólica nas novas formas comunicacionais digitais .............................. 174

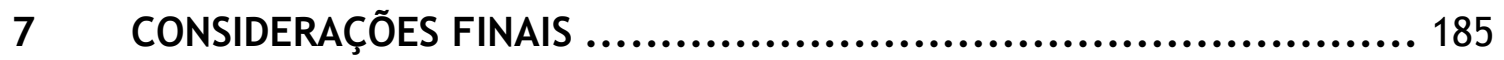

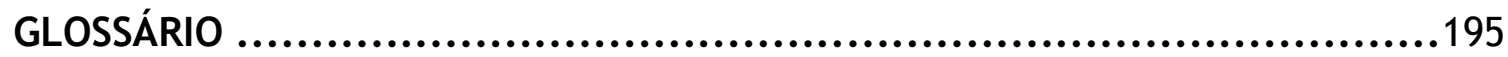

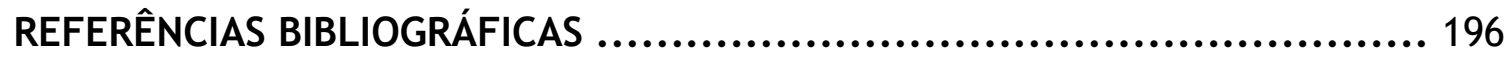

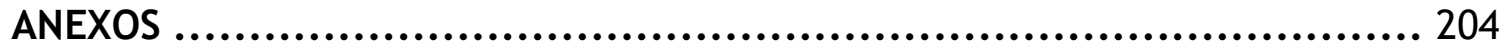


Introdução 
Na era digital, a comunicação a distância mostra-se como um caminho de reformulação da agenda feminista, balizada por novas estratégias de intervenção política e de atuação, levando em conta outras dinâmicas e a revolução das formas de expressão pessoal e interpessoal.

Esta tese busca confirmar tal afirmação que espelha o objeto de estudo desta pesquisa-ação, com a imbricação de atividades acadêmicas e o percurso prático no universo de uma organização não governamental feminista.

O início de meu percurso na Escola de Comunicações e Artes da Universidade de São Paulo (ECA/USP) caminha paralelamente à trajetória junto ao movimento feminista organizado. Em 1996, quando retorno do Canadá, onde residi por oito anos, começo a trabalhar como coordenadora da organização nãogovernamental (ONG) Rede Mulher de Educação, que tem sede na cidade de São Paulo. No ano seguinte, movida pela paixão à academia e ao trabalho de educação para novas relações sociais entre homens e mulheres, concretiza-se o sonho de ingressar na USP, ao ser aprovada para o Curso de Gestão de Processos Comunicacionais (ECA/CCA). Em 1999, o projeto do curso lato sensu, sob orientação do Prof. Dr. Adilson Odair Citelli, intitulado EDUCOMUNICANDO Intervenção Comunicacional das ONGs para a visibilidade de discurso e a conquista de novas parcerias - Estudo de caso: Rede Mulher foi aprovado com distinção e louvor, tendo contribuído para a atualização da prática feminista.

No segundo semestre de 1999, persegui a intenção de ingressar no mestrado, cursando uma disciplina como aluna especial. Em seguida, apresentei o projeto de dissertação com a nítida convicção de que em muito contribuiria para minha prática cotidiana, avançando nos conhecimentos adquiridos anteriormente. A pesquisa-ação intitulada Gênero e Educação para Intervenção da Mídia foi aprovada em 2002, também sob orientação do Prof. Dr. Adilson Odair Citelli, representando mais um passo importante no sentido de efetivar o cruzamento dos saberes entre a academia e o universo das ONGs feministas, visando ao avanço da luta pela cidadania plena feminina.

Como coordenadora-executiva e de comunicação da ONG Rede Mulher de 
Educação, em caráter voluntário a partir de 2008, e atuando também junto a outra ONG - Associação Mulheres pela Paz -, sempre me deparei com o desafio da necessidade do aprofundamento na reorientação da prática de intervenção feminista, considerando a influência dos meios de comunicação de massa no pensar e agir das pessoas, acentuada pela revolução tecnológica. Por isso, em 2008, após aprovação de meu projeto de doutorado, dei continuidade ao percurso imprescindível de aprofundamento do objeto de pesquisa focado na comunicação e no feminismo, sob orientação da Prof ${ }^{a}$. Dra ${ }^{a}$. Maria Cristina Castilho Costa.

Debruçando-me na teoria, ao mesmo tempo em que a aplico em experiências práticas, venho confirmando que o feminismo e a comunicação caminham lado a lado, colocando-se como um trajeto inegável e necessário para o avanço da luta pela equidade das relações de gênero. O radicalismo (no sentido marxista de ir à raiz das coisas) desta luta deve estar acima do sectarismo vigente na visão sobre os meios de comunicação de massa, por parte de um grande número de organizações não-governamentais. A mídia não representa a salvação e nem a destruição, mas é um fundamental campo de intervenção para o avanço da cidadania ativa. É esta a aura que reveste o percurso desta instigante tese.

O capítulo 2 - Comunicação e Feminismo - se traduz em uma proposta de demonstrar que, ao longo da história das lutas pela emancipação da mulher, a mídia vem prestando um papel inegável e imprescindível nesse trajeto, desde os meios impressos, aos analógicos e digitais. Assim, uma prática efetiva de comunicação a distância necessita de um olhar positivo ao potencial transformador propiciado pelas TIC. Sem dúvida, na era digital, as possibilidades de intervenção feminista encontram uma ressonância ainda mais potente.

O capítulo 3 - As teorias comunicacionais e a evolução dos instrumentos de informação e comunicação - apresenta um aprofundamento do processo de construção do campo específico da comunicação, cuja busca de legitimidade tem início na década de 1910, na Escola de Chicago, nos Estados Unidos. Apresenta o 
quadro de evolução das pesquisas de comunicação, que começa com o modelo comportamentalista, passando pelo modelo funcionalista, abordando a Teoria Crítica e os frankfurtianos, para chegar a Jürgen Habermas, que é identificado como o mais notável expoente da segunda geração de pensadores da Escola de Frankfurt. É Habermas um dos principais autores que embasam esta tese, com sua teoria da ação comunicativa, desembocando em Jesús Martin-Barbero, com o modelo das mediações - entende o receptor como um ser ativo, que ressignifica a mensagem. Esse processo ocorre “entre" a emissão e a recepção, no campo denominado mediações. O pensamento de Paulo Freire também permeia este trabalho. Depois de discorrer sobre a evolução das mídias tradicionais, esta parte do trabalho chega a mais ampla das revoluções com o advento das mídias digitais, que têm na internet sua maior expressão. Pela primeira vez é possível a interação virtual em tempo real, além da amplificação do papel do público que passa de mero consumidor para produtor de mensagens. As novas noções de tempo e espaço, o novo modo de sentir, pensar e agir podem acelerar a harmonização das relações de gênero construídas socialmente, aceitas culturalmente e mantidas historicamente por milênios.

No capítulo 4 - As teorias feministas e a violência contra a mulher - dá-se um mergulho nos estudos existentes, indo desde a diferenciação entre o movimento feminista e o movimento de mulheres, passando pela introdução da expressão relações sociais de gênero, por Simone de Beauvoir, até as diferentes correntes e ondas do feminismo, noção de patriarcado e a tríade classe-gêneroraça. Helleieth Saffioti e Joan Scott são autoras fundamentais para dar sustentação às reflexões. Parte deste capítulo é dedicada à violência contra a mulher como conseqüência do binômio dominação / subordinação, dada a especificidade deste recorte na tese, considerada a mais forte e trágica expressão da construção social de gênero, que coloca o homem em posição de superioridade à mulher, desencadeando relações desiguais de poder e oportunidades, com malefícios para toda a sociedade. Tal especificidade também está intrinsecamente ligada à experiência pessoal desta pesquisadora, enquanto sobrevivente de violência doméstica. 
Ao se debruçar na esfera ideológica, para entender a construção das identidades masculina e feminina, esta tese busca - no capítulo 5 , intitulado A constituição do imaginário e a representação da mulher na mídia - refletir sobre termos como símbolos, mitos, arquétipos, esquemas, estereótipos, preconceitos... O embasamento teórico fica a cargo de reconhecidos estudiosos da área como Gilbert Durand, Michel Maffesoli e Mikhail Bakhtin. Este percurso é importante por demonstrar que no emaranhado dinâmico das estruturas do imaginário vão se tecendo laços que podem ser fortalecidos, mas que também podem ser afrouxados no sentido de desfazer os moldes dos papeis estabelecidos pela dinâmica social. Pela comunicação a distância é possível alterar os condicionamentos provocados por mitos e imagens. Além disso, as mídias digitais trazem a perspectiva de novas dinâmicas de representação da mulher.

Nos capítulos 6 e 7 - As possibilidades da era digital e Considerações finais - destacam-se as atividades práticas dialógicas da pesquisa-ação, com a descrição de todas as etapas da experiência. Demonstram que as narrativas feministas e a sociedade em rede estão redefinindo o conceito de democracia, bem como as possibilidades de diferentes dinâmicas de construção simbólica nas novas formas comunicacionais digitais. Tais reflexões se embasam no pensamento de autores/as como Manuel Castells, Pierre Lévy, Donna Haraway, Lucia Santaella e Massimo Di Felice.

Com os resultados desta tese, espera-se oferecer contribuições concretas para uma ação mais efetiva do movimento feminista por meio da comunicação a distância, em busca do mesmo objetivo de pioneiras dessa luta: uma sociedade com equidade de direitos - relações de igualdade, com respeito às diferenças -, sem o que não se pode conquistar a democracia e a cidadania plena. 
2

Comunicação e feminismo 
O mundo não é. 0 mundo está sendo.

Paulo Freire

Se nós não inventamos, outros nos inventam.

Jesús Martin-Barbero 
Ao buscar a interface entre a comunicação e o feminismo, esta pesquisa de doutorado tem como premissa o fato de que ambos os saberes possuem uma existência intrinsecamente entrelaçada. Reconhece, também, que, nas lutas pela emancipação da mulher, a mídia tem exercido uma função importante, prestando um papel inconteste nessa trajetória que vai dos meios impressos, passando pelos analógicos até os digitais, seja no cenário nacional ou internacional. Essa intervenção transformadora caminha na contracorrente da linguagem estereotipada, seja escrita ou imagética, que reforça o sexismo e outras discriminações.

Para propor uma prática efetiva de comunicação a distância - centrada na identificação de discursos e maneiras de veiculá-los -, a pesquisadora é contrária à visão massificante da Escola de Frankfurt e adepta ao potencial político transformador abalizados por autores como Jürgen Habermas, Jesús Martin- Barbero e Paulo Freire. Assim, torna-se necessário, como premissa básica, gestar a comunicação, internamente, com objetivos claros e partilhados entre integrantes dos grupos envolvidos nesta pesquisa-ação, o que significa buscar permanentemente a resposta-base à pergunta enfatizada por Habermas (1989, p.91) ${ }^{1}$, e que pode ser resumida da seguinte forma: “com que modo de agir em comum as pessoas querem se comprometer?". Para ele, a comunicação traduz-se na busca de entendimento, reconhecendo as conexões entre a dimensão da subjetividade e da intersubjetividade. Uma ação comunicativa deve ter um destinatário capaz de recebê-la. Nenhuma ação se caracteriza como tal, se do outro lado não houver quem receba, considerando sempre que o(a) receptor(a) só vai digeri-la, depois de refazê-la dentro de si mesmo(a), para, posteriormente, participar de uma ação de comunicação de forma contínua com outros agentes sociais. E como bem explica Habermas (1989, p.91),

[...] os membros do coletivo têm que chegar a uma decisão

${ }^{1}$ HABERMAS, J. Consciência moral e agir comunicativo. Tradução: Guido Antônio de Almeida. RJ: Ed. Tempo Brasileiro. 1989. p. 91 
comum. Eles têm que tentar convencer-se mutuamente de que é de interesse de cada um que todos ajam assim. Em semelhante processo, cada um indica ao outro as razões por que ele pode querer que um modo de agir seja tornado socialmente obrigatório. Cada pessoa concernida tem que poder convencer-se de que a norma proposta é, nas circunstâncias dadas, 'igualmente boa' para todos.

Na história da humanidade, de forma resumida, as formas de comunicação começaram com a oralidade, sendo, por muito tempo, a única maneira de transmitir informação e conhecimento. Depois, foram inventados instrumentos que nada mais são do que tecnologias de produção e transmissão de informação e conhecimento, como o alfabeto, no ano 1700 a.C. Eram vários os suportes utilizados, até chegar-se ao papel: folhas de palmeiras na Índia; ossos de baleia e dentes de foca, pelos esquimós; conchas, cascos de tartaruga e depois bambu e seda, na China; a pedra, o barro, a casca de árvores, por outros povos. As matérias-primas mais próximas ao papel $^{2}$ foram o papiro, inventado pelos egípcios, e o pergaminho, feito de pele de animais. Depois, outra revolução da comunicação se dá com a invenção da tipografia, no século XV, por Gutemberg; até chegar às mídias analógicas, no início do século XX (rádio, TV e cinema); e as mídias digitais, no final desse mesmo século, integrando telecomunicações e informática, tendo na internet a sua expressão mais relevante.

\subsection{A mulher nas mídias tradicionais}

Ao mergulhar na história de mulheres jornalistas que utilizaram a força dos textos impressos em prol da causa feminista, chega-se à heroína Olympe de

\footnotetext{
${ }^{2}$ A palavra papel é originária do latim 'papirus'. Nome dado a um vegetal da família 'Cepareas' (Cyperua papyrus). A medula de seus caules era empregada, pelos egípcios, há 2400 anos antes de Cristo. Entretanto, foram os chineses os primeiros a fabricarem o papel como o atual. Por volta do século VI a.C. os chineses começaram a produzir um papel de seda branco próprio para pintura e para escrita. O papel produzido após a proclamação da invenção diferenciava-se desse, unicamente pela matéria-prima utilizada. Disponível em <www.invivo.fiocruz.br/cgi> . Acesso: 8 Dez 2011.
} 
Gouges (1748-1793), pseudônimo de Marie Gouze, que morreu guilhotinada na praça da Revolução, em Paris. Ela era também escritora e autora de peças de teatro. Incansável defensora dos direitos da mulher e da democracia, ela elaborou a Declaração dos Direitos das Mulheres e da Cidadã, em setembro de 1791, "para igualar-se à outra do homem, aprovada pela Assembléia Nacional. [...] Foi condenada como contra revolucionária e denunciada como uma mulher ‘desnaturada'”, de acordo com documento divulgado pela Biblioteca Virtual dos Direitos Humanos (UNIVERSIDADE DE SÃO PAULO, 2011) ${ }^{3}$.

Os escritos da filósofa francesa Simone de Beauvoir (1908-1986), já nos anos 1940, trouxeram um impacto para o desenvolvimento dos estudos sobre as relações sociais de gênero em todo o mundo, exercendo influência na chamada segunda onda do feminismo, historicamente delimitada a partir dos anos 1960, transpondo as lutas sufragistas - direito ao voto - da primeira onda, iniciada em 1860. Uma de suas célebres frases inaugura a utilização da expressão "gênero" Ninguém nasce mulher, torna-se mulher -, pois delimita a diferença entre o caráter biológico e o de construção social entre os sexos, que é culturalmente aceita e historicamente mantida. As mulheres romperam as barreiras do mercado de trabalho e das universidades, incorporando-se à democracia representativa.

No Brasil, é por meio de publicações que o feminismo, “como doutrina que prioriza a igualdade entre os sexos e a redefinição do papel da mulher na sociedade" (Costa, 1998, p. 25) ${ }^{4}$, chega logo nas primeiras décadas do século XIX. Nísia Floresta ${ }^{5}$,

\footnotetext{
3 UNIVERSIDADE DE SÃO PAULO, Biblioteca Virtual de Direitos Humanos. Disponível em: $<$ http://www.direitoshumanos.usp.br/index.php/Documentos-anteriores-\%C3\%A0-cria\%C3\%A 7\%C3\%A3oda-Sociedade-das-Na\%C3\%A7\%C3\%B5es-at \%C3\%A9-1919/declaracao-dos-direitos-da-mulher-e-dacidada-1791.html>. Acesso em: 10 out. 2011.

${ }^{4}$ COSTA, A.A.A. Trajetória e Perspectivas do Feminismo para o Próximo Milênio. In: Metamorfoses Gênero na perspectiva interdisciplinar. Salvador: UFBA, Núcleo de Estudos Interdisciplinares sobre a mulher. 1998. p. 25

5 “Chamava-se Dionísia Faria Rocha, Dionísia Gonçalves Pinto ou Dionísia Freire Pinto (há divergências). Nasceu no sítio Floresta, hoje Paray, interior do Rio Grande do Norte, em 1810, e teve vida acidentada. Casou-se aos treze anos, separou-se ao quatorze. Optou por acompanhar a família quando seu pai, advogado, resolveu fixar residência em Pernambuco, onde foi assassinado em 1828, nas proximidades de Recife. Com a morte do pai, 'separada do marido', viu-se na contingência de ser arrimo de família. Sua carreira profissional
} 
[...] considerada a primeira feminista brasileira, que ao regressar ao país, depois de uma temporada na Europa (convivendo com o feminismo que naquele momento florescia nos salões, principalmente de Paris e Londres), publica em 1832 a tradução livre da obra pioneira de Mary Wollestonecraft, "A Vindication of the Rights of Women", com o título "Direito das mulheres e injustiça dos homens". Posteriormente, Nísia publica, de sua autoria, os livros "Opúsculo Humanitário", em 1853 e "Conselhos à Minha Filha”, em $1842 .^{6}$

Ainda no início da segunda metade do século XIX, aparecem os jornais femininos, fornecendo os primeiros alicerces para o feminismo como movimento social, com a publicação, em 1852, do “Jornal das Senhoras”, que seguia uma linha editorial voltada para a emancipação da mulher. Segundo Costa (1998, p. $25-26)^{7}$,

[...] Outros jornais femininos (cerca de duas dezenas em todo o Brasil) surgem ainda [...], com os mesmos objetivos, dando especial destaque à luta sufragista e ao direito das mulheres de acesso à educação formal.

E foi por intermédio de um artigo que a bióloga Berta Lutz (1894-1976)

\footnotetext{
de educadora iniciou-se nesse momento, quando contava com apenas 20 anos de idade, como professora de um colégio da capital pernambucana. Parece ter sido nessa fase adversa de sua vida, de sérias restrições econômicas, seu encontro com o jovem acadêmico Manuel Augusto de Faria Rocha. [...] Casaram-se em 1832, no mesmo ano da publicação da primeira edição de seu livro. Um ano depois, já residindo em Porto Alegre, ficou viúva e responsável pelo sustento de seus dois filhos e sua velha mãe. Mudou-se para o Rio de Janeiro, em 1838, onde fundou uma escola feminina, Colégio Augusto. Em1856, viajou para a Europa, onde morreu, em 1885, aos 75 anos. [...] Direitos das Mulheres e Injustiça dos Homens, [foi] objeto de intensa pesquisa por parte de Constância da Silva. A estudiosa se propunha a desvendar o mistério em torno do mito em torno de Nísia Floresta, de forma a elaborar um trabalho de fundamento científico, resgatando a imagem da intelectual [...], colocando-a entre as feministas do porte de Mary Wollstonecraft. [...] A primeira feminista do Brasil é atualíssima em sua luta político-social. Uma voz vibrante e incansável que defendia a República em um regime monárquico, a abolição da escravatura e o saber indígena num país de escravos e excluídos, a educação feminina diante de completo analfabetismo e os direitos das mulheres num tempo em que as relações sociais e contratuais livres não as incluíam como participantes da sociedade civil. Fonte: MELO, E.; FREITAS, J.M.; FERREIRA, V.M. Representações de Gênero - Abordagem Histórica. In: Ensaios sobre gênero e educação. FAGUNDES, T.C.P.C. Salvador: UFBA - Pró-Reitoria de Extensão, 2001. p. 33, 41 e 44.

${ }^{6}$ Ibidem. p. 25-26

${ }^{7}$ Ibidem. p. 26-27
} 
conseguiu repercutir suas ideias feministas. Tratava-se de uma resposta a um jornalista carioca que, ao falar sobre os progressos femininos nos Estados Unidos e na Inglaterra, afirmara que isto não repercutiria na vida das mulheres deste país. No artigo publicado na Revista da Semana (14/12/1918, apud, SCHUMAHER; BRAZIL. 2000. p.106) $)^{8}$, intitulado Somos filhos de tais mulheres e que foi assinado com o pseudônimo de Iracema, Bertha fez um chamado veemente às mulheres para fundarem uma associação de luta por seus direitos. Na história do feminismo brasileiro, ela é considerada pioneira. Trecho desse artigo é prova contundente de tal reconhecimento:

[...] Tudo quanto está sucedendo estava previsto. As democracias vão começar aprendendo a ser a expressão fiel, sincera de um regime social e político da igualdade humana. A mulher, que não pudera conseguir ser compreendida na declaração dos Direitos do Homem proclamados pela Revolução Francesa, a grande pária e dolorosa escrava, que usa braceletes de ouro em memória das algemas de ferro, foi libertada pela guerra e sentada ao lado do homem no trono da terra. As mulheres russas, finlandesas, dinamarquesas, norueguesas, suecas, alemãs e inglesas - quer dizer, uns cento e vinte milhões de mulheres na velha Europa já partilham ou brevemente partilharão do governo, não só contribuindo com o seu voto para a eleição dos legisladores, como podendo ser elas próprias eleitas para o exercício do poder legislativo.

A jornalista gaúcha Carmem da Silva (1919-1985) é considerada uma das pioneiras na imprensa do país. Seu pensamento libertador feminista influenciou gerações de mulheres sob a segunda onda, principalmente os textos da coluna $A$ arte de ser mulher, na revista Cláudia, a partir de 1963. A interatividade com as leitoras dessa experiência está retratada em sua autobiografia, onde Silva (1984, p. 123$)^{9}$ destaca:

\footnotetext{
${ }^{8}$ SCHUMAHER, S.; BRAZIL, E. V. Dicionário Mulheres do Brasil - de 1500 até a atualidade. RJ: Jorge Zahar Editor. 2000. p. 106

${ }^{9}$ SILVA, C. Histórias híbridas de uma senhora de respeito, SP: Editora Braziliense, 1984. p. 119-120 e 123.
} 
[...] Meus artigos caíram como UFOs incandescentes no marasmo em que dormitava a mulher brasileira naquela época. Logo comecei a receber uma avalancha de cartas de todos os tons: desesperados apelos, xingamentos, pedidos de clemência: deixem-nos em paz, preferimos não saber! Consciência dói - olé se dói... (p. 119-120) [...] Encaixei na revista como uma cravelha no buraco certo, se é que me posso permitir imagem tão fálica. Entre mim e as leitoras o vínculo se estreitava num calor de briguinhas, desafios e reconciliações que me ajudavam a pôr a nu os seus (nossos) medos e ambivalências,... [...) Foi assim que levei oito anos de aparente indefinição antes de empregar a palavra bicho-papão 'feminismo'. E só escrevi, preto no branco, quando já não escandaliza ninguém - exceto as pessoas, e não são poucas, que continuam escandalizadas até hoje - mas essas não têm jeito mesmo, azar o delas.

São inúmeras as contribuições de mulheres estrangeiras e brasileiras que utilizaram a escrita - pelos livros, jornais e revistas - para disseminar pensamentos que contribuíram para o avanço das condições equitativas entre os sexos. Patrícia Galvão (1910-1962), a Pagu, árdua defensora da ocupação do espaço público pela mulher, escritora e jornalista,

[...] militante comunista, teve grande destaque no movimento modernista iniciado em 1922. Foi a primeira mulher presa no Brasil por motivações políticas. [...] Com 18 anos, mal completara o Curso na Escola Normal da Capital (São Paulo, 1928) e já está integrada ao movimento antropofágico, de cunho modernista, sob a influência de Oswald de Andrade e Tarsila do Amaral. É logo considerada a musa do movimento. Em 1930, um escândalo para a sociedade conservadora de então: Oswald separa-se de Tarsila e casa-se com Pagu. Especula-se que eles eram amantes desde a época que Oswald era casado. No mesmo ano, nasce Rudá de Andrade, segundo filho de Oswald e primeiro de Pagu. Os dois se tornam militantes do Partido Comunista. ${ }^{10}$

O movimento modernista remete ao papel de destaque que as mulheres

\footnotetext{
${ }^{10}$ Disponível em: <pt.wikipedia.org/wiki/Pagu>. Acesso em: 14 abr 2011.
} 
tiveram como produtoras de arte, publicamente reconhecidas, pela primeira vez nessa fase. Costa (2002), em seu livro A imagem da mulher: um estudo de arte brasileira, publicado em 2002, resgatando sua dissertação de mestrado defendida nos anos 1980, na Universidade de São Paulo, buscou se aprofundar na análise da posição feminina na sociedade brasileira, debruçando-se em 1300 obras - do século XVII ao início do século XX, que contempla o movimento barroco, neoclassicismo, romantismo, realismo e modernismo. Para Lins $(2004)^{11}$ a abordagem foi inovadora na medida em que,

[...] nela a imagem não é considerada apenas como uma coadjuvante, uma mera ilustração, uma referência histórica ou uma curiosidade. Ao contrário, para a autora, é a partir das imagens que se elabora, reconstitui e ressignifica o quadro das relações sociais e o papel da mulher nessas relações.

0 trabalho descortina na pintura dos retratos femininos em épocas diversas, a representação da força das mulheres, detectando símbolos que remetem à vanguarda da busca pelo protagonismo no equilíbrio da construção social de gênero, com atitudes antagônicas aos preceitos de uma sociedade patriarcal. Ao mergulhar na obra que perpassa minuciosamente os movimentos artísticos brasileiros, com uma cuidadosa contextualização política, cultural e sócio-econômica, causa surpresa e inquietação contemplar imagens que emanam o poder feminino, contradizendo estudos que concluem pelo papel de completa submissão exercido pelas mulheres em determinadas épocas. Para Costa $\left(2002\right.$, p. 67) ${ }^{12}$,

[...] nesse grupo de pinturas [de Aleijadinho, no Santuário de Bom Jesus de Matozinhos, em Congonhas do Campo/MG)], o grande personagem é Jesus, mas já podemos perceber a presença mais significativa de mulheres, como Nossa Senhora e Maria

\footnotetext{
${ }^{11}$ LINS, J. W. Resenha de "A imagem da mulher: um estudo de arte brasileira” de Cristina Costa. Revista Estudos Feministas, RJ. UFRJ. Jan-Abr., ano/vol.12, número 001. 2004. Disponível em: $<$ http://redalyc.uaemex.mx/pdf/381/38112121.pdf>. Acesso em: 14 abr. 2011.

${ }^{12}$ COSTA, C. A imagem da mulher: um estudo de arte brasileira. RJ: Senac Rio. 2002. p. 67
} 
Madalena. Diferindo do patriarcalismo oriental de tradição judaica, essas personagens encarnam um feminino valorizado por qualidades que the parecem inerentes como castidade, obediência, pureza. Assim, restaura-se de certa forma uma visão positiva da mulher, encontrada também em muitos mitos medievais que enaltecem sua função conceptiva, generosidade e infindável ternura.

Em outra passagem, Costa (2002, p. 93) ${ }^{13}$ destaca que

[...] a imagem da mulher que povoa essas telas [pintura neoclássica] não é nova. É a mesma figura feminina que inspirara os artistas barrocos na criação das madonas com as quais ornavam os templos dedicados às muitas devoções marianas no período colonial. Agora, ela podia ser admirada nas cenas de costumes, nas quais aparecia com encanto semelhante e suscitando, provavelmente, idêntica devoção. Figuras de mulheres estavam presentes também nos exercícios de desenho e pintura indispensáveis à disciplinada formação artística acadêmica. Eram os nus artísticos resultantes dos trabalhos com modelos vivos, que davam aos artistas a possibilidade de representação da nudez feminina, antes só permitida nas cenas bíblicas com Adão e Eva no Paraíso.

A cada inovação nas formas de expressão e de transmissão da informação e do conhecimento potencializam-se as estratégias para alcançar maior poder de disseminação nas mensagens de libertação da opressão patriarcal pelas mulheres. Com o desenvolvimento do cinema, por exemplo, foram produzidos filmes tanto baseados em fatos reais, como meras ficções, que influenciaram e continuam a influenciar diferentes gerações de mulheres, com foco na problemática das desigualdades de gênero, tendo ambos os sexos se dedicado ao roteiro, à direção, à produção, à fotografia, etc. Dentre as produções, destacam-se ${ }^{14}:$ A Estirpe do Dragão (EUA-1944), dirigido por Harold S. Bucquet, "um clássico que retrata a vida e o cotidiano de uma forte mulher

\footnotetext{
${ }^{13}$ Ibidem. p. 93

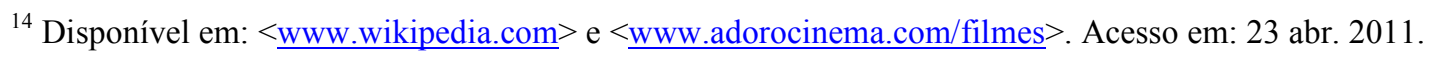


que vive uma vida monótona no campo"; Bagdad Café (Alemanha Ocidental e EUA - 1987), dirigido por Percy Adlon, conta a história de uma turista alemã que abandona o marido na estrada após uma discussão e chega ao posto-motel Bagdad Café, em pleno deserto do Arizona. A dona do local, que acabara de expulsar o marido de casa, a recebe de maneira rude. Com o tempo, tornamse amigas.

Shirley Valentine (Inglaterra/EUA-1989), com direção do inglês Lewis Gilbert, narra a vida de uma esposa tradicional, que se cansa de limpar a casa, lavar roupa e preparar o jantar do marido. Em busca de seus sonhos de juventude, viaja para a Grécia com uma amiga, durante quinze dias. “Longe do marido e dos filhos, talvez encontre o amor e quem sabe a liberdade. Mas será isso mesmo o que Shirley Valentine quer?” Frida (EUA-2002), dirigido por Julie Taymor, retrata a vida de Frida Kahlo (1907-1954), uma grande artista mexicana. Além de se tratar de uma mulher que obteve o reconhecimento público pelo seu sucesso profissional, seu comportamento na esfera privada causou estranheza à sociedade, pois “teve um casamento aberto com Diego Rivera, seu companheiro também nas artes, e ainda um controverso caso com o político Leon Trostky e com várias mulheres." Nunca sem minha filha (EUA-1991), com direção de Brian Gilbert, mostra a história real de uma americana casada com um médico iraniano que vivia nos EUA há vinte anos. Para sua surpresa, em uma viagem de férias à terra natal do marido, este a transforma em prisioneira, sob os preceitos do islamismo. Tem início uma peregrinação para fugir de lá com sua filha: "a luta e a coragem desta mulher surpreendente transformam esta história num envolvente relato."

$\mathrm{Na}$ produção brasileira, o cinema tem levado mulheres e homens a questionarem os papéis assimétricos entre os sexos, que foram construídos e aceitos culturalmente há milênios. O filme Leila Diniz (1987), de Luiz Carlos Lacerda, aborda a vida de uma mulher de vanguarda. Nascida em 1945 e morta em 1972, na Índia, em um acidente de avião, a atriz 
[...] quebrou tabus de uma época em que a repressão dominava o Brasil, escandalizou ao exibir a sua gravidez de biquíni na praia, e chocou o país inteiro ao proferir a frase: Transo de manhã, de tarde e de noite. Considerada uma mulher à frente de seu tempo, ousada e que detestava convenções. Foi invejada e criticada pela sociedade machista das décadas de 1960 e 1970. Era malvista pela direita opressora, difamada pela esquerda ultra-radical e tida como vulgar pelas mulheres da época. Leila falava de sua vida pessoal sem nenhum tipo de vergonha ou constrangimento. Concedeu diversas entrevistas marcantes à imprensa, mas a que causou um grande furor no país foi a entrevista que deu ao jornal O Pasquim em 1969. Nessa entrevista, ela, a cada trecho, falava palavrões que eram substituídos por asteriscos, e ainda disse: Você pode muito bem amar uma pessoa e ir para cama com outra. Já aconteceu comigo. ${ }^{15}$

Zuzu Angel (2006), dirigido por Sérgio Rezende, narra a história real de uma mulher que se destacou no mundo da moda e lutou de forma incansável em busca de respostas verdadeiras para o desaparecimento do filho nos porões da ditadura militar. De acordo com SCHUMAHER e BRASIL (2000, p. 535) ${ }^{16}$

[...], os mais duros do regime militar, a estilista teve sua vida transformada a partir do momento em que seu filho Stuart Angel foi preso, torturado e morto nas dependências de uma unidade da Aeronáutica, no Rio de Janeiro. Zuzu viu-se impotente para apurar o que de fato havia acontecido com seu filho e sequer conseguiu encontrar o corpo dele para enterrá-lo. Iniciava-se, então, sua luta contra o regime político autoritário. Ao mesmo tempo em que seua fama de estilista ganhava os mercados norteamericano e europeu, travava uma intensa luta pela verdade sobre o desaparecimento de Stuart.

Mais recentemente, o filme $\operatorname{Diva}^{17}$ (2009) transforma as aventuras e desventuras femininas em comédia. Dirigido por José Alvarenga Júnior, é

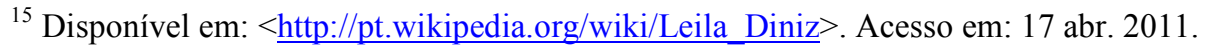

${ }^{16}$ Ibidem. p. 535

${ }^{17}$ Divã é inspirado na obra literária de mesmo nome, de autoria de Martha Medeiros.
} 
protagonizado pela atriz Lília Cabral, intérprete do mesmo papel em peça de teatro e em seriado de televisão de mesmo nome. A protagonista é uma mulher, com dois filhos, que vive aparentemente feliz em seu casamento, até iniciar um processo de análise com um psicanalista, quando descobre suas insatisfações e a vontade de conhecer a liberdade de realizar sonhos.

\subsubsection{A mulher no rádio e na TV}

Mesmo reconhecendo que as vozes que circulam nas ondas de rádio são, até hoje, predominantemente, masculinas - e, para tal constatação, basta sintonizar emissoras AM e FM -, foi também através desse veículo que mulheres brasileiras quebraram tabus sexistas no início do século XX. A primeira emissora, a Rádio Sociedade, foi fundada pelo antropólogo Roquete Pinto, em 1923, na cidade do Rio, com uma programação cultural, artística e musical. A popularização deste veículo de comunicação, a partir dos anos 1930, graças à publicidade, culminou com a diversificação de programas e com uma forte inserção no cotidiano das pessoas. Na era do radioteatro e das radionovelas brasileiras, período que compreende os anos 1940 aos 1960, o universo feminino ganhou destaque nas tramas - já que era o público-alvo -, além de representar a ascensão profissional tanto na representação de papéis, como na criação de histórias. A Rádio Nacional, transmitiu a primeira radionovela, com duração de dois anos, intitulada Em busca da Felicidade, original cubano de Leandro Blanco com adaptação de Gilberto Martins, tendo como atrizes Ísis de Oliveira, lara Sales, Flora May, Zezé Fonseca e Lourdes Mayer (além de Maria Helena, que era responsável pela locução e narração dos acontecimentos dos capítulos anteriores, e de frisar o prestígio dos produtos Colgate - o primeiro patrocinador de radionovela). Também pioneiras são Fatalidade, que foi escrita por Oduvaldo Vianna, e Mulheres de Bronze, adaptada de um folhetim francês. Em 1951, foi ao ar o maior sucesso de todos os tempos, com três anos de duração: $O$ Direito de Nascer, do cubano Félix Caignet. Segundo Calabre (2007), “em um levantamento sobre as radionovelas transmitidas pela Rádio Nacional, no período entre 1941 e 
1959, foram localizados 807 títulos e um total de 118 autores." Dentre esse nomes, encontram-se três mulheres: Dilma Lebon (18 novelas), Ivani Ribeiro (16) e Janet Clair (13), sendo as duas últimas mais conhecidas, tendo ambas migrado para a telenovela. Seus históricos são facilmente encontrados em sites de busca $^{18}$, publicações ou dicionários especializados. Ivani Ribeiro, no início dos anos 1940, contrariava o destino da vida doméstica reservado às mulheres e se lançava na carreira artística radiofônica (SCHUMAHER e BRAZIL, 2000, p. 285286) ${ }^{19}$ :

[...] Cleyde Alves Ferreira nasceu em 1922 na cidade de Santos (SP), onde diplomou-se pela Escola Normal. Em 1939 foi para São Paulo cursar a Faculdade de Filosofia. Iniciou sua carreira como intérprete de canções folclóricas e sambas, alguns de sua autoria, na Rádio Educadora, aos 17 anos. Mais tarde criou, na mesma emissora, os programas Teatrinho da Dona Chiquinha e As mais belas cartas de amor, que the trouxeram grande prestígio junto ao público. Sua dramaturgia foi experimentada, inicialmente, através das radionovelas, onde também participava como atriz. [...] Na TV Excelsior ganhou projeção nacional, a partir de 1975, quando escreveu 13 telenovelas consecutivas, todas com grande audiência.

A interiorana, de origem humilde, Janete Clair resolveu traçar um destino similar, começando a trabalhar fora de casa ainda na tenra adolescência, para, poucos anos mais tarde, trilhar uma brilhante carreira no mundo do rádio e televisão, passando, inclusive, a exercer o papel de provedora da família, por circunstâncias da história política brasileira (SCHUMAHER; BRAZIL, 2000, p. 289-290) ${ }^{20}$ :

[...] Janete Emmer [1925-83, nascida em Conquista/MG] era filha

\footnotetext{
18 CAlabre, L. Nos tempos da radionovela. Comunicação \& Sociedade, São Bernardo do Campo, PósCom-Metodista, a. 29, n. 49, p. 65-83, $2^{\circ}$ sem. 2007. e disponível em:

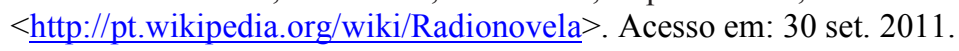

19 . Ibidem. p. 285-6 .

${ }^{20}$ Ibidem. p. 289-290
} 
da costureira Carolina e do comerciante libanês Salim Emmer. Começou a vida profissional como cantora, na rádio de Franca, interior paulista - onde a família se murada -, interpretando canções francesas e árabes. Aos 13 anos, passou a trabalhar em um escritório comercial, onde aprendeu datilografia, habilidade que the seria fundamental mais tarde. Aos 16 anos, submeteu-se a um teste para radioatriz na rádio Tupi-Difusora, em São Paulo. Aprovada, começou a trabalhar como locutora, sob a orientação da atriz Cacilda Becker. Ainda na Tupi Paulista, conheceu o dramaturgo Dias Gomes, com quem se casou em 1950. Janete e Dias tiveram três filhos - Alfredo, Guilherme e Denise. A maternidade acabou afastando Janete do trabalho no rádio e aproximando-a do ofício de escritora de radionovelas, que podia ser executado em casa. [...] $\mathrm{Na}$ década de 1960, passou a trabalhar na televisão. [...] Com o golpe militar de 1964, seu marido, Dias Gomes, perdeu o emprego por causa de seu engajamento político. Janete passou a trabalhar em dobro, para garantir o sustento da família. (...) Seu maior sucesso foi na TV Globo, com a novela Selva de Pedra (1973).

A televisão brasileira é inaugurada em 3/4/1950, com uma transmissão que se restringia ao saguão dos Diários Associados, onde havia poucos aparelhos e uma audiência que assistiu à apresentação do padre cantor mexicano Frei José Mojica. Em seguida, no porto de Santos, chegam os equipamentos da RCA comprados por Chateaubriand, proprietário de uma rede de jornais e emissoras de rádio. Em 18 de setembro, ele inaugura a TV Tupi. A logomarca da emissora, uma indiazinha com cocar e penas na cabeça, é a primeira imagem a aparecer na telinha, com a frase Está no ar a TV no Brasil, sob a voz feminina de Sônia Maria Dorce, então com cinco anos de idade. Em seguida, é também uma mulher, Lolita Rodrigues, que canta o Hino da TV ou Canção da TV, composta por Marcelo Tupinambá, com letra de Guilherme de Almeida. “A transmissão acontece das $18 \mathrm{~h}$ às $23 \mathrm{~h}$ e os profissionais vêm do rádio, jornal e teatro. Juntos buscam descobrir e desenvolver a nova linguagem que a televisão exige." ${ }^{21}$ E no primeiro programa da emissora, apresentado por Homero Silva, lá estão mulheres pioneiras: Hebe Camargo, Wilma Bentivegna, a poetisa Rosalina Coelho Lisboa, o

\footnotetext{
${ }^{21}$ Disponível em: <http//www.tudosobretv.com.br>. Acesso: 17 abr. 2011.
} 
balé de Lia Aguiar, além de Yara Lins que empresta a voz para ecoar o prefixo da TV Tupi - PRF3. E a presença da mulher não parou de crescer e se destacar nas diversas profissões que a televisão agrega, numa demonstração concreta de que existe um mundo de possibilidades para além das quatro paredes do lar. A ousadia dessas mulheres, principalmente no início, contribuiu sobremaneira para o longo caminho de busca da autonomia e cidadania plena feminina. A temática dessa luta também passou a ser incorporada pelos homens. Exemplo clássico é o do seriado Malu Mulher, criado e dirigido por Daniel Filho. Logo no primeiro capítulo apresenta a mais grave expressão do desequilíbrio de gênero: a violência doméstica. Apresentado pela Rede Globo, de 24/5/1979 a 22/12/1980, tem como protagonista a atriz Regina Duarte, além de Denis Carvalho e Narjara Tuletta no elenco principal. A melodia Começar de novo, na voz da cantora Simone, é o tema do seriado que bem expressa o trajeto de separação e busca da identidade perdida por uma mulher, numa época de avanço legislativo com a instituição oficial do divórcio ${ }^{22}$. Ainda não era fácil conviver nas diversas esferas sociais como mulher separada, principalmente pelo assédio sexual provocado pelo estigma da desquitada, que se traduzia no jargão popular mulher não direita.

Data da mesma época, o início de um programa de televisão que iria contribuir para abalizar mudanças de comportamento pelas mulheres, abrindo canais de diálogo entre as apresentadoras e um público que agregava as diversas classes sociais, dado o potencial deste meio de comunicação de massa. TV Mulher foi ao ar de 1980 a 1986, transmitido pela Rede Globo nas manhãs de

\footnotetext{
${ }^{22}$ Até o ano de 1977, quem casava, permanecia com um vínculo jurídico para o resto da vida. Caso a convivência fosse insuportável, poderia ser pedido o 'desquite', que interrompia com os deveres conjugais e terminava com a sociedade conjugal. Significa que os bens eram partilhados, acabava a convivência sob mesmo teto, mas nenhum dos dois poderia recomeçar sua vida ao lado de outra pessoa cercado da proteção jurídica do casamento. Naquela época, também não existiam leis que protegiam a União Estável e resguardavam os direitos daqueles que viviam juntos informalmente. A Lei do Divórcio, aprovada em 1977, concedeu a possibilidade de um novo casamento, mas somente por uma vez. O 'desquite' passou a ser chamado de 'separação' e permanecia, até hoje, como um estágio intermediário até a obtenção do divórcio. Foi com a Constituição de 1988 que passou a ser permitido divorciar e recasar quantas vezes fosse preciso. 1988 A Constituição de 1988, em seu artigo 226, estabelece que o casamento civil pode ser dissolvido pelo divórcio, mas desde que cumprida a separação judicial por mais de um ano nos casos expressos em lei, ou comprovada separação de fato por mais de dois anos. Disponível em: $<\underline{\mathrm{http}} / / / \mathrm{www}$. ibdfam.org.br/>. Acesso em: 23 abr. 2011.
} 
segunda a sexta-feira, com produção de Nilton Travesso e Régis Cardoso, tendo como madrinha a cantora Elis Regina. “A composição mais marcante de equipe do TV Mulher é a primeira, com Marília Gabriela, Ney Gonçalves Dias, Ala Szerman, Xênia Bier, Marta Suplicy e Clodovil Hernandez"23. Além do conservadorismo vigente, o país ainda era governado pelos militares quando a sexóloga Marta Suplicy falava sobre vagina e orgasmo feminino, com naturalidade, em plena manhã. Foi quando as "Senhoras de Santana" 24 exigiram, em vão, o fim do programa. Em 1982, ela lança o livro Conversando sobre Sexo, com edição própria, inspirado nas cartas das telespectadoras, abordando, em 24 capítulos, desde a forma básica de se conversar sobre o tema até as etapas da sexualidade humana. A trajetória de Marta Suplicy - deputada federal, prefeita de São Paulo e atualmente senadora - é um exemplo do percurso de autonomia traçado ou almejado pelas mulheres brasileiras.

As telenovelas, outro alvo dos protestos das "Senhoras de Santana", vêm apresentando tramas e personagens fortes que rompem com preconceitos sexistas, entre outros, amplificando os efeitos da luta pela autonomia da mulher, tal como ocorrido em Mulheres Apaixonadas, de Manoel Carlos, em 2003, cujo merchandising social também se voltava para a grave questão da violência doméstica - com a personagem de classe média Raquel, vivida pela atriz Helena Ranaldi, vítima do agressor Marcos, interpretado por Dan Stulbach. O poder de penetração deste gênero ficou evidenciado no aumento significativo do número de mulheres que passaram a denunciar seus parceiros - cerca de $30 \%{ }^{25}-$, iniciando um processo de transformação pessoal em busca do resgate da autonomia. Aliás, o merchandising social desta trama focou outros problemas sérios e polêmicos de nossa sociedade: o alcoolismo, os maus-tratos às pessoas

\footnotetext{
${ }^{23}$ Disponível em < http://pt.wikipedia.org/wiki/TV_Mulher > . Acesso em: 23 abr. 2011

${ }^{24}$ As Senhoras de Santana foram um grupo brasileiro formado no começo da década de 1980 que protestava contra a sexualidade e sua discussão na televisão, defendendo a censura. Ao lado da organização Tradição, Família e Propriedade foi um dos primeiros grupos católicos tradicionalistas e conservadores que conseguiu

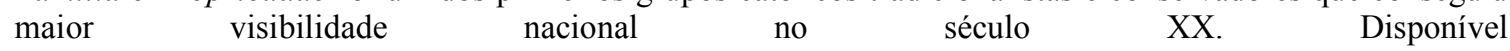
em: $<$ http://pt.wikipedia.org/wiki/Senhoras_de_Santana $>$. Acesso em: 23 abr. 2011.

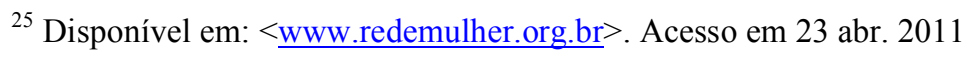


idosas e a homossexualidade. Atualmente, são inúmeros os gêneros de programas feitos por, com e/ ou para mulheres, tanto em canais abertos como na televisão fechada.

\subsection{A mulher nas mídias digitais}

$\mathrm{Na}$ era digital, as possibilidades de intervenção feminista encontram uma ressonância ainda mais potente. A revolução das tecnologias da informação e comunicação (TIC) provocou novas noções de tempo e espaço, um novo modo de sentir, pensar e agir. A imagem midiática passou a exercer uma influência sem precedentes na produção dos sentidos das pessoas, seres responsáveis, conjuntamente, pela concretização da utopia de uma sociedade justa e igualitária.

Assim sendo, qualquer proposta política e/ou educativa não pode ignorar as TIC e a complexidade que as envolve, bem como a crise paradigmática ora instalada. A constituição do imaginário está conectada tanto com a construção cultural das relações de gênero, como com a influência das TIC na formação das pessoas, considerando-se que a realidade se constitui a partir da objetividade e da subjetividade. Como bem salienta Cristina Costa ${ }^{26}$ : “Há um jogo entre o eu e a cultura. Por um lado, a cultura se impõe a nós; por outro, somos parte da cultura. Trata-se de um jogo entre algo que me contém, mas não me contém inteira".

Para projetar o futuro é necessário rever o passado e analisar o presente, tempo este em que as TIC passaram a representar o poder maior na nova ordem política, econômica, social e cultural. No emaranhado dinâmico das estruturas do imaginário vão se tecendo laços que podem ser fortalecidos - no sentido de perpetuar as desigualdades de gênero - ou afrouxados, visando desfazer os moldes dos papéis estabelecidos pela dinâmica social. É pelo trabalho educativo,

\footnotetext{
${ }^{26}$ Aula ministrada em 25/5/2010, na disciplina Fundamentos da Comunicação e Expressão Humanas, na USP/ECA, coordenada por ela.
} 
que transforma seres humanos em agentes políticos, que se consegue alterar os condicionamentos. Essas "verdades" estão presentes na construção social de gênero, que é tecida a partir das diversas redes de relações na vida de uma pessoa: família, Igreja, escola, associações populares, partidos políticos, meios de comunicação de massa...

Apesar de haver limitações do movimento feminista em utilizar a comunicação como ferramenta estratégica de luta, há que se ressaltar, primeiramente, o caráter pioneiro de criação de conteúdos educativos em ambiente virtual, voltados para TIC e transformação social, direcionados, principalmente, para o universo das organizações não-governamentais (ONGs) e comunidades de base espalhadas mundo afora. Também há que se levar em conta as dificuldades de financiamento por que passam tais entidades, em épocas de crise econômica mundial, o que provoca a escassez ainda maior de recursos humanitários.

Em vários países ao redor do mundo, um número razoável de mulheres tem se convertido em ativas participantes dos temas relacionados ao uso das TIC. Essa incidência abrange aspectos que vão desde o fato de assegurar o acesso local, participação em reuniões nacionais sobre políticas de TIC, desenvolvimento de serviços de informação, redes virtuais de mulheres e produção de material de capacitação com perspectiva de gênero, assim como oferecer recomendações em temas como desenho e implementação de TIC. Mas, estariam elas produzindo conteúdo e formato adequados à linguagem das novas tecnologias, visando interagir com um público para mais amplo? Para Costa $(2011)^{27}$,

[...] Processa-se no ciberespaço uma ruptura em relação às características típicas das mídias analógicas também no que diz respeito à produção e direcionamento discursivo: a centralidade e a unidericionalidade do fluxo comunicativo dão lugar à multidirecionalidade e à descentralização. Podemos dizer que o princípio de gerenciamento de informações se sobrepõe, nas

\footnotetext{
${ }^{27}$ COSTA, M. C. C. Interatividade-entre graus de liberdade e intencionalidades narrativas. p. 3. Disponível em: <www.intercom.org.br> . Acesso em: 23 abr. 2011.
} 
novas mídias, ao de apresentação. 0 que se mostra ao usuário, na maioria das vezes, é um número quase ilimitado de combinações de textos - imagens, sons, animações e textos escritos - que desafiam sua compreensão e que pretendem substituir o prazer sensível da projeção cinematográfica e a familiaridade da recepção televisiva. Nesse sentido, Lucinda Furlong afirma que a estrutura narrativa das mídias digitais é muito mais lúdica do que narrativa.

Com os resultados do percurso e da análise desta pesquisa-ação, pretendese oferecer recomendações concretas para o movimento feminista, demonstrando-se as possibilidades de comunicação a distancia alavancadas pelas mídias digitais, notadamente as redes sociais, que configuram novas formas de representação da mulher. O cerne do objeto de estudo está na hipótese de que as mídias digitais alteram os modelos estereotipados de representação da mulher, propiciando uma ação mais efetiva do movimento feminista através da comunicação a distância. E, sem sombra de dúvida, os desafios atuais perseguem o mesmo objetivo de pioneiras dessa luta: uma sociedade com equidade de direitos - relações de igualdade, com respeito às diferenças -, sem o que não se pode conquistar a democracia e a cidadania plena. 
As teorias comunicacionais e a

evolução dos instrumentos de informação e comunicação 
Nós, seres humanos, jamais pensamos sozinhos ou sem ferramentas. As instituições, as línguas, os sistemas de signos, as técnicas de comunicação, de representação e de registro informam profundamente nossas atividades cognitivas: toda uma sociedade cosmopolita pensa dentro de nós.

Pierre Lévy 


\subsection{A construção de um campo científico específico}

Para alcançar a visão transformadora da comunicação em que se ancora esta pesquisa - com base em estudos que demarcam os anos 1960, principalmente com o desenvolvimento da Teoria da Ação Comunicativa, por Jürgen Habermas, e do Modelo das Mediações, por Jesús Martin Barbero -, faz-se primordial abordar o processo de construção do campo específico da comunicação. 0 longo percurso em busca de legitimidade científica se dá a partir do início do século XX, tendo a Escola de Chicago como moradia inaugural. Por carregar consigo a intrínseca interdisciplinaridade, este campo científico ficou apensado às analogias dos esquemas das ciências da natureza, antes de conquistar sua autonomia e reconhecimento. Segundo Mattelart, A. e M. (1999, p. 29$)^{28}$,

[...] Desde a década de 1910, a comunicação nos Estados Unidos encontra-se ligada ao projeto de construção de uma ciência social sobre bases empíricas. A Escola de Chicago é sua sede. Seu enfoque microssociológico dos modos de comunicação na organização das comunidades harmoniza-se com uma reflexão sobre o papel da ferramenta científica na resolução dos grandes desequilíbrios sociais. A supremacia dessa escola durará até as vésperas da Segunda Guerra Mundial. Os anos 40 veem instalar-se outra corrente: a Mass Comunication Research, cujo esquema de análise funcional desloca a pesquisa para medidas quantitativas, mais aptas a responder à exigência proveniente dos administradores da mídia.

O quadro de evolução das pesquisas de comunicação começa com o modelo comportamentalista, nos anos 1930, voltado para o efeito das mensagens junto ao público. Centrado no emissor, analisa a mensagem como via única e com efeito narcotizante, tendo na propaganda política sua maior expressão, tanto

\footnotetext{
${ }^{28}$ MATTELART, Armand e Michèle. História das teorias da comunicação. Tradução: Luiz Paulo Rouanet. SP: Edições Loyola. $2^{\text {a }}$ ed. 1999. p. 29.
} 
que tal estratégia utilizada pelos Aliados na II Grande Guerra Mundial é tida como fator decisivo para a derrota dos alemães. Para Matellart, A. e M. (1999, p. 37) ${ }^{29}$ : “essa visão instrumental consagra uma representação da onipotência da mídia, considerada ferramenta de “circulação eficaz dos símbolos'”.

Em seguida, os estudos avançam para o modelo funcionalista, indo um pouco além dos efeitos ao contemplar o conteúdo das mensagens. Para esse modelo a mensagem tem via de mão dupla, a partir do cruzamento dos diferentes processos envolvidos na produção: quem diz (comunicador), o que (conteúdo da mensagem), para quem (características do público), através de que canal (rádio, televisão, jornais, etc.), com que efeito (resultantes). A noção de feedback (emissor-receptor-emissor) amplia o entendimento sobre os processos comunicacionais, mas este modelo ainda prioriza o emissor. Considera a influência dos formadores de opinião - intermediários como sujeitos difusores maiores: agentes comunitários, lideranças políticas, padres - , mas de forma direta, isto é, sem considerar a possibilidade das mensagens se desdobrarem pela ação de um novo agente mediador. Foi em 1948 que Lasswell propôs esta fórmula que se intitulou communication research - Quem diz o quê por que canal e com que efeito? - alargando um pouco mais os horizontes do modelo comunicativo de análise ao incluir os efeitos e os conteúdos, resultando na ampliação dos elementos de orientação para a abordagem ao público. Com relação às funções do processo comunicacional, Mattelart A. e M. $(1999 \text {, p. } 41 \text { e } 42)^{30}$ cita três definidas por $H$. Lasswell, um dos precursores nos estudos da área, acrescentando uma quarta defendida por dois outros sociólogos:

[...] o processo de comunicação cumpre três funções na sociedade: 'a) a vigilância do meio, revelando tudo o que poderia ameaçar ou afetar o sistema de valores de uma comunidade ou das partes que a compõem; b) o estabelecimento de relações entre os componentes da sociedade para produzir uma resposta

\footnotetext{
${ }^{29}$ Ibidem. p. 37

${ }^{30}$ Ibidem. p. 41-42
} 
ao meio; c) a transmissão da herança social’ [Lasswell, 1948].

e

[...] Paul F. Lazarsfeld (1901-1976) e Robert K. Merton (nascido em 1910) acrescentam a essas três funções uma quarta, o entertainment ou diversão, e tornam o sistema mais complexo com o discernimento da possibilidade de disfunções, bem como de funções latentes e manifestas.

Para se aprofundar no trajeto de consolidação do campo específico da comunicação, é relevante abordar também os conceitos de Teoria Crítica da sociedade e de sociedade de massas desenvolvidos na década de 1940, por estudiosos da Escola de Frankfurt. A Teoria Crítica da sociedade é importante porque analisa a dominação da sociedade de massa para perpetuar o capitalismo, no século XX, que não havia sido prevista pelos grandes pensadores até então. 0 marco dessa abordagem teórica, que se contrapõe à Teoria Tradicional (cartesiana), se dá em 1937, com o ensaio-manifesto publicado por Max Horkheimer, sob o título Teoria Tradicional e Teoria Crítica. A sociedade de massas é analisada enquanto fenômeno social sob a perspectiva de classe. Adorno e Horkheimer são responsáveis pela criação do conceito de "indústria cultural", que data desta mesma década, na Universidade Columbia, nos Estados Unidos, nação onde se encontravam exilados depois do triunfo de Hitler na Alemanha. Segundo Mattelart, A. e M. (1999, p. 77), eles "analisam a produção industrial dos bens culturais como movimento global de produção da cultura como mercadoria." 31

Vattimo (1992, p. 65) ${ }^{32} \mathrm{faz}$ uma releitura dos estudos da época, indo além das consequências atribuídas aos mass media, que se resumem à massificação, à manipulação do consenso e aos erros dos regimes totalitários. Ele destaca que,

[...] o advento dos media comporta também efectivamente uma

\footnotetext{
${ }^{31}$ Ibidem. p.77

${ }^{32}$ VATTIMO, Gianni. A sociedade transparente. Relógio d'Água Editores Ltda. Lisboa: 1992. p. 65
} 
acentuada mobilidade e superficialidade da experiência, que contrasta com as tendências para a generalização do domínio, ao mesmo tempo que dá lugar a um espécie de 'enfranquecimento' da própria noção de realidade, com o consequente enfraquecimento também de toda a sua coacção. A 'sociedade do espetáculo' de que falaram os situacionistas não é apenas a sociedade das aparências manipuladas pelo poder; é também a sociedade em que a realidade se apresenta com características mais brandas e fluidas, e em que a experiência pode adquirir os aspectos da oscilação, do desenraizamento, do jogo.

Com a volta dos estudiosos da Escola de Frankfurt para a Alemanha, após o fim da II Guerra Mundial (1948-1951), as contribuições no campo da comunicação se consagram por intermédio de projetos com novos expoentes, autores estes identificados como a segunda geração de pensadores. 0 filósofo Jürgen Habermas, nascido em 1929, é o que mais se notabiliza, assumindo a direção da Escola de Frankfurt, logo depois dos eventos que marcaram o ano de 1968, indicado por Adorno, que se retira do cargo. Ele é o autor da Teoria da Ação Comunicativa, contribuição fundamental para alicerçar o posterior Modelo das Mediações baseado nos estudos culturais. A principal contribuição de Habermas, que se tornou consenso praticamente mundial, é associar a ação à comunicação. Se para Gramsci, este processo ocorre por coersão, para Habermas, é pelo convencimento. É uma característica da sociedade burguesa, que é uma sociedade não só baseada no exercício da força, mas na relação de publicidade entre nós.

Habermas estudou a ação comunicativa relacionada a uma função política. Segundo sua teoria, as informações e ações políticas vão se legitimar através do mecanismo da opinião pública. Nas democracias modernas, para enfrentar a deterioração da esfera pública - aquele espaço de discussão da vida pelas pessoas, que vai além da vida doméstica, da igreja e do governo -, o mecanismo da opinião pública se torna um instrumento de manipulação. Para Habermas, a sociedade é legitimada pelos bens de consumo. O Estado utiliza o mecanismo de se legitimar através da opinião pública. Nas democracias modernas, acaba 
acontecendo o contrário. Há uma deterioração dessa esfera pública. Para enfrentá-la, o mecanismo da opinião pública é tornado um instrumento de manipulação. A ação comunicativa examina as perspectivas em que se move essa opinião pública. Os indivíduos sofrem os efeitos da manipulação, sendo, assim, mal formados. O filósofo atenta para a importância da comunicação não sofrer os efeitos manipulativos. Para tanto, discorre sobre a ética do discurso - baseada principalmente na definição de verdade de caráter universal - enquanto prolongamento do agir comunicativo. Habermas (1989, p. 86) ${ }^{33}$ enfatiza que

[...] De acordo com a ética do Discurso, uma norma só deve pretender validez quando todos os que possam ser concernidos por ela cheguem (ou possam chegar), enquanto participantes de um Discurso prático, a um acordo quanto à validez dessa norma.

É importante destacar que a análise sobre as estruturas da esfera pública traz uma contribuição significativa na concepção desta pesquisa que pretende sugerir uma estratégia de comunicação a distancia para organizações ligadas a movimentos sociais, na medida em que discorre sobre as condições básicas para sua efetivação. Com bem enfatiza Habermas (1984, p. 287) ${ }^{34}$,

[...] Uma opinião rigorosamente pública só pode estabelecer-se à medida em que ambos os setores da comunicação passam a ser intermediados por aquele outro, que é o da 'publicidade crítica'. Certamente, uma tal mediação só é possível, hoje, numa ordem de grandeza sociologicamente relevante, por meio da participação de pessoas privadas num processo de comunicação formal conduzido através das esferas públicas internas às organizações.

\footnotetext{
${ }^{33}$ Ibidem. p. 86

${ }^{34}$ HABERMAS, J. Mudança estrutural da esfera pública. Tradução: Flávio R.Kothe. RJ: Edições Tempo Brasileiro. 1984. p. 287
} 
Segundo análise de Citelli (2004, p. 32) ${ }^{35}$, outros estudiosos da mesma geração, com destaque para a produção latinoamericana, concluem, então, que a evolução dos estudos comunicacionais é demarcada pela "encruzilhada das impossibilidades se não recebem o devido aporte crítico que inclui a compreensão dos mecanismos sociais de produção, circulação e consumo das mensagens".

\subsubsection{O modelo das mediações}

É a partir desse ponto de impasse, nos anos 1980, que o modelo das mediações começa a se consolidar. Com base nos estudos culturais desenvolvidos desde o início dos anos 1960, centra-se na recepção da mensagem. Considera que o receptor não é passivo, quer dizer, vai receber as influências socioculturais do meio em que vive, gestando, assim, outro significado à mensagem. Esse processo de ressignificação da mensagem ocorre "entre" a emissão e a recepção, no campo denominado mediações. A capacidade de reflexão - de ressignificação das pessoas situa-se exatamente no campo das mediações, isto é, além da emissão e recepção, existe um processo de diálogo interior, cujos sentidos se completam no jogo ideológico das experiências culturais e sociais, como família, amigos, escola, igreja, associações, etc. De acordo com Citelli (2004, p. 51 $53 / 57)^{36}$,

[...] Nos anos 60, a força dos movimentos sociais provocou a revisão do papel do/a receptor/a. "Está aí, o cerne do 'contrato', o aspecto regulador das intenções comunicativas a partir de códigos comuns e que transforma, pela aceitação do 'pacto', o receptor em elemento atuante no processo geral de configuração da mensagem. Fica, inclusive, por conta do receptor, prosseguir ou não o diálogo, redefinir ou manter linhas propositivas, prosseguir ou suspender sequências discursivas. [...] 0 sentido se constitui, pois, não em conjuntos de regras abstratas, mas nas

\footnotetext{
${ }^{35}$ CITELli, A. O. Comunicação e Educação. A linguagem em movimento. $3^{\text {a }}$ ed. SP: Senac. 2004 p. 32

${ }^{36}$ Ibidem. p. 51-53/57
} 
práticas sociais e culturais que cortam de forma mais tensa ou mais harmônica os sujeitos falantes. (...) Postos no 'entre', os signos serão animados não só por experiências de um sujeito, mas por cadeias históricas coletivas, que nele vão deixando suas marcas à maneira dos icebergs redesenhados ao longo da trajetória marinha.

[...] É evidente que o desenvolvimento das formas produtivas modernas acabou, em função de objetivos específicos do capital, também se interessando pelo destinatário.

A teoria de Jesus Martin Barbero ${ }^{37}$ sobre as mediações encontra ressonância para redesenhar os estudos comunicacionais. Suas pesquisas indicam que o meio sofre a ação das várias instâncias da sociedade. Barbero desloca a discussão dos meios para as mediações e a ação efetiva das mensagens. Ao invés dos meios representarem somente recursos de produção, isto é, as empresas de comunicação e seus interesses, eles devem funcionar levando em conta as diversas instâncias envolvidas, as diversas redes de relações das pessoas. Deste modo, o fenômeno da recepção é mediado por instâncias da sociedade. São os intermediários que mediam a influência, portanto, podem, através de práticas participativas, manipular os meios e os recursos, dominando suas linguagens e técnicas. A tese central é a de que existe um desordenamento provocado pela nova sensibilidade, ligada à variação prefigurativa, formada por relações que são marcadas pela desordem cultural, desterritorialização e hibridismos de linguagem.

Além de Barbero, autor espanhol que vive na Colômbia desde 1963, este modelo foi desenvolvido com profundidade por estudiosos como o mexicano Guilhermo Gomes Orozco e o argentino Nestor García Canclini. Aqui no Brasil, vários pesquisadores da Escola de Comunicação e Artes da Universidade de São Paulo (ECA/USP) debruçaram-se, a partir desses estudos, em um campo específico do saber que se intitulou educomunicação. Os professores Ismar de

\footnotetext{
${ }^{37}$ MARTIN-BARBERO, J. Heredando el futuro. Pensar la educacion desde la comunicacion. In Revista Nómadas. S/d
} 
Oliveira Soares e Adilson Odair Citelli propuseram um novo curso de licenciatura intitulado Educomunicação, que passou a ser ministrado em 2011 na mesma universidade. Em poucas palavras, educomunicação pode ser definida como a interrelação entre a Comunicação Social e a Educação, enquanto um campo de intervenção social específico.

Uma pesquisa que durou dois anos e foi finalizada em 1998, do Núcleo de Comunicação e Educação (NCE) da ECA/USP, coordenada pelo professor Ismar de Oliveira Soares $(1998, \text { p. } 3)^{38}$, enfoca a emergência de um novo espaço profissional:

\begin{abstract}
[...] A pesquisa partiu da evidência de que transformações profundas vêm ocorrendo no campo da constituição das ciências, em especial as humanas, assim como no campo das artes na sociedade contemporânea, na qual assiste-se a uma derrubada de fronteiras, de limites, de autonomias e de especificações. Ao seu final, a investigação concluiu que efetivamente um novo campo do saber mostra indícios de sua existência, e que já pensa a si mesmo, produzindo uma meta-linguagem, elemento essencial para sua identificação como objeto autônomo de conhecimento: o campo da inter-relação Comunicação/ Educação. [...] Trata-se de uma re-fundamentação teórico-prática e ético-política, tanto do agir pedagógico, quanto do agir comunicativo. Ambos estão entremeados pela linguagem que além do valor de conhecimento, agrega também um valor de ação social que pode unir, separar, influir, integrar, persuadir, modificar ou fundamentar os comportamentos dos indivíduos. Ninguém consegue escapar dos processos interativos das linguagens, isto é, do famoso agir comunicativo de Habermas, pois o estar-no-mundo implica a existência de um saber partilhado que permite negociação de leituras do mundo, emolduradas por confluências e discordâncias dos sentidos das nossas linguagens.
\end{abstract}

Nas premissas desses estudos para uma educação com, pela e para a comunicação, seguindo o famoso esquema step by step, chega-se ao seguinte

\footnotetext{
${ }^{38}$ SOARES, Ismar de Oliveira. O campo da Comunicação/Educação, suas subáreas e a emergência de um novo espaço profissional. Pesquisa do Núcleo de Comunicação e Educação da Escola de Comunicações e Artes da Universidade de São Paulo (NCE/ECA/USP). 1998. SP. p. 3
} 
emaranhado de ações: 1) Gestão do agir comunicativo, no interior dos grupos; 2) Domínio instrumental (domínio das técnicas de funcionamento, compreensão e reconhecimento das técnicas de formatação e percepção das lógicas econômicas e políticas que influenciam os mecanismos de produção, circulação e consumo); 3) Leitura crítica dos meios; 4) Mecanismos efetivos de intervenção. Ao final deste trabalho, este esquema também será de grande utilidade na gestão de uma estratégia de comunicação a distância que estreite os laços entre as pessoas e encurte os caminhos para uma sociedade mais justa e igualitária. Esses objetivos a serem perseguidos estão em sintonia com o sentido primeiro da palavra comunicação, contido em sua própria composição: tornar COMUM uma AÇÃO. Segundo Baccega (2002, p. 7-8) $)^{39}$,

[...] comunicação é interação entre sujeitos... Para que haja comunicação é preciso que os interlocutores tenham uma 'memória' comum, participem de uma mesma cultura. Isso porque a comunicação se manifesta nos discursos e os discursos que circulam na sociedade se constituem a partir da intertextualidade.

Como a comunicação só se efetiva quando ela é apropriada e se torna fonte de outro discurso, segundo Baccega $\left(2000-2001\right.$, p. 20) ${ }^{40}$, para o enunciatário deve estar presente a condição de enunciador. Ele é, portanto, enunciatário/ enunciador." Já para Deleuze e Guattari (2009, p. 51) ${ }^{41}$,

Não existe enunciado individual, nunca há. Todo enunciado é o produto de um agenciamento maquínico, quer dizer, de agentes coletivos de enunciação (por 'agentes coletivos' não se deve entender povos ou sociedades, mas multiplicidades).

\footnotetext{
39 BACCEGA, M. A. Comunicação: interação emissão/recepção. In: Revista Comunicação e Educação. no.23. ECA-USP/Ed.Salesiana. jan-abr/2002. p. 7/8

${ }^{40}$ BACCEGA, M. A. A construção do campo comunicação/educação: alguns caminhos. In: Revista USP. no.48. dez-jan-fev/2000-2001. p.20

${ }^{41}$ DeleuZE, G.; GUATTARI, F. Mil Platôs Capitalismo e Esquizofrenia. Volume 1. Tradução: Aurélio Guerra Neto e Célia Pinto Costa. Editora 34. SP: 2009 (6 ${ }^{\mathrm{a}}$ reimpressão). p. 51.
} 
Retoma-se o entendimento básico de que a humanidade sempre desenvolveu estratégias na forma de se instrumentalizar para a transmissão de informação e reconhecimento. Por outro lado, como bem frisou Costa $(2011)^{42}$,

[...] As teorias sobre ciências da comunicação estiveram atreladas, isto é, acompanhando o desenvolvimento dos meios de comunicação. Assim, o modelo funcionalista se baseia no esquema linear do telégrafo: um emissor, um meio, um código, um receptor. Com as mídias de massa esse esquema se complexifica para um emissor, muitos meios e milhares de receptores (um para muitos); até chegarmos à atualidade da comunicação em rede, quando temos muitos para muitos, numa relação mediada por computadores. Nesse sentido, a Escola de Frankfurt diz respeito a um momento da comunicação de massa.

Chega-se ao final do século 20 celebrando-se a mais ampla das revoluções com o advento das mídias digitais, que têm na internet sua maior expressão. Pela primeira vez, é possível a interação virtual em tempo real, além da amplificação do papel do público que passa de mero consumidor para produtor de mensagens. Conforme Di Felice (2008, p. 21-22) ${ }^{43}$,

[...] Historicamente, a humanidade passou por três grandes revoluções comunicativas (remete-se o leitor ao texto de $M$. Baldini, 1989), três momentos importantes que marcaram não apenas o surgimento de uma nova forma de comunicar e de novos meios, mas também a introdução de novas possibilidades de comunicação e, consequentemente, de novas práticas de socialização e de interação com o meio ambiente.

A primeira revolução surge com a escrita no século $V$ a.C, no Oriente Médio, e marca a passagem da cultura e da sociedade oral para a cultura e a sociedade da escrita. A segunda, ocorrida na metade do século XV, na Europa, provocada pela invenção dos caracteres móveis e pelo surgimento da impressão criada por

\footnotetext{
${ }^{42}$ Explicação frisada pela orientadora Maria Cristina Castilho Costa, durante reunião realizada em 1/3/2011.

${ }^{43}$ DI FELICE. M. Das tecnologias da democracia para as tecnologias da colaboração. In: Do público para as redes - A comunicação digital e as novas formas de participação social. (org: o próprio). São Caetano do Sul/SP. Difusão Editora. 2008. p.21/22
} 
Johannes Gutenberg, causará a difusão da cultura do livro e da leitura, até então circunscrita a grupos privilegiados. A terceira, desenvolvida no Ocidente na época da Revolução Industrial, entre os séculos XIX e XX, foi marcada pelo início da cultura de massa e caracterizada pela difusão de mensagens veiculadas pelos meios de comunicação eletrônicos.

[...] Na época contemporânea, a humanidade estaria enfrentando uma ulterior revolução comunicativa, implementada pelas tecnologias digitais, que, numa concepção histórica, constituiria a quarta revolução e que, como as outras, estaria ocasionando importantes transformações no interior dos distintos aspectos do convívio humano.

E é esta recente revolução comunicativa que traz ao movimento feminista perspectivas pungentes na luta pela transformação das relações sociais de gênero, na medida em que as mídias digitais podem alterar a percepção e materialização assimétrica de poder entre os sexos, que coloca o homem em situação de dominação com trágicas consequências para a sociedade. As novas noções de tempo e espaço, o novo modo de sentir, pensar e agir podem acelerar a harmonização de relações construídas socialmente, aceitas culturalmente e mantidas historicamente por milênios.

Mas, para se chegar ao aprofundamento desta quarta revolução comunicativa, é importante discorrer sobre a evolução das mídias impressas e eletrônicas, as quais foram fundamentais para o estágio atual de transmissão da informação e conhecimento pela humanidade.

\subsection{A evolução das mídias tradicionais}

Antes de tudo, faz-se relevante destacar que as profundas transformações atuais no universo das mídias tradicionais - impressa e eletrônica - estão ocorrendo no campo técnico, político, econômico e sociocultural. As mídias antigas e novas caminham para a confluência total, com um sistema contaminando o outro, graças à tecnologia da informatização, elemento comum 
a todas elas: computadores multimídia, discos laser, CD-ROM, aparelhos de facsímile de última geração, banco de dados portáteis, livros eletrônicos, redes de videotextos, telefones inteligentes, salélites de transmissão direta e a internet com seus novos recursos multimídia.

Um breve mergulho histórico mostra que a antiga mídia remonta a Gutenberg que, no século XV, desenvolveu a impressora tipográfica, comemorada, então, como a primeira tecnologia moderna de produção e transmissão de informações em larga escala. Ela proporciona o nascimento da comunicação de massa impressa - livros, jornais e revistas.

Mas, bem antes disso, outras invenções contribuíram sobremaneira para o aperfeiçoamento das formas de comunicação. Em 1837 que foi inventado o telégrafo com fios, pelo americano Samuel Morse. A transmissão de mensagens por pulsos elétricos, através de um só fio: este foi o código criado por Morse. “ $O$ novo instrumento de comunicação foi importante na vitória da União (estados do Norte) contra os estados Confederados (do Sul), na Guerra de Secessão dos Estados Unidos." 44 Remonta a 1793 a inauguração do sistema de comunicação a distância, quando da inauguração do telégrafo óptico, por Claude Chappe, com finalidades militares. Segundo Mattelart (1999, p. 14-15) ${ }^{45}$,

[...] A Inglaterra já efetuou sua 'revolução da circulação' [vias fluviais, marítimas e terrestres], que começa a integrar-se naturalmente à nova paisagem da revolução industrial em andamento.

Em contrapartida, na mesma época, a França continua em busca da unificação de seu espaço de comércio interior. Nesse reino fundamentalmente agrícola, o discurso sobre as virtudes dos sistemas de comunicação é diretamente proporcional ao estados das carências.

[...] Quesnay [François Quesnay - 1694-1774] mostra-se atento ao conjunto de circuitos do mundo econômico, que ele procura

\footnotetext{
${ }^{44}$ Disponível em $<$ http://www.ciberespaco.com.br/index.php?title=Das cavernas \%C3\%A 0 aldeia global $>$. Acesso: 10 Abr 2011.

${ }^{45}$ Ibidem. p. 14-15.
} 
apreender como "sistema", "unidade". Inspirando-se em seus conhecimentos sobre a dupla circulação do sangue, esse médico imagina uma representação gráfica da circulação das riquezas em um Tableau économique (1758). Dessa figura geométrica em ziguezague, na qual se entrecruzam e justapõem linhas que indicam o comércio entre a terra e os homens, por um lado, e entre as três classes que compõem a sociedade, por outro, obtém-se uma visão macroscópica de uma economia de "fluxos". A Revolução de 1789 [Revolução Francesa - 5/5/1789 a 9/11/1799] libera esses fluxos ao tomar uma série de medidas, como a adoção do sistema métrico, destinadas a acelerar a unificação do território nacional.

O telégrafo sem fios foi inventado pelo italiano Marconi, em 1896. Representou o nascimento da tecnologia de telecomunicações, propiciando, através de um transmissor, enviar combinações de sinais elétricos, que representam letras, por um cabo elétrico que liga o emissor ao receptor, para o registro dos sinais em fitas de papel. É bidirecional: uma pessoa emite e a outra recebe. Essa relação segue a dinâmica do desenvolvimento histórico da tecnologia ligada ao comércio (o emissor), que não oferece o direito de resposta e participação.

[...] Marconi se baseou em estudos apresentados em 1897 por Nikola Tesla para em 1899 realizar a primeira transmissão pelo Canal da Mancha. A teoria de que as ondas electromagnéticas poderiam propagar-se no espaço, formulada por James Clerk Maxwell, e comprovada pelas experiências de Heinrich Hertz, em 1888, foi utilizada por Marconi entre 1894 e 1895. Ele tinha apenas vinte anos, em 1894, quando transformou o celeiro da casa onde morava em laboratório e estudou os princípios elementares de uma transmissão radiotelegráfica, uma bateria para fornecer eletricidade, uma bobina de indução para aumentar a força, uma faísca elétrica emitida entre duas bolas de metal gerando uma oscilação semelhante as estudadas por Heinrich Hertz, um Coesor, como o inventado por Édouard Branly, situado a alguns metros de distância, ao ser atingido pelas ondas, acionava uma bateria e fazia uma campainha tocar. ${ }^{46}$

\footnotetext{
${ }^{46}$ Disponível em: $<$ http://pt.wikipedia.org/wiki/Guglielmo_Marconi $>$. Acesso em: 20 set. 2011.
} 
O telefone, inventado em 1876, por Graham Bell, foi celebrado como uma grande revolução no sistema de telecomunicações, pois, pela primeira vez, era possível a emissão e a recepção da voz, simultaneamente. Emitida como onda eletromagnética, a voz se transforma em sinal elétrico, fazendo com que o dispositivo do aparelho receptor vibre ao receber os sinais, reproduzindo as ondas sonoras originais. É a partir da utilização das ondas magnéticas que também aparecem dois outros sistemas de telecomunicações, que invadem o mundo como grandes mídias de massa: o rádio e a televisão.

O detalhamento desses pormenores, além dos que se seguem sobre o desenvolvimento do rádio e da televisão, apesar de parecerem desnecessários, mostram-se importantes para que se tenha um parâmetro da dimensão do tempo e espaço entre a velha e nova mídia, configurando-se o paradoxo de velocidade e da adaptação humana. Outra razão está ligada à tentativa de romper com o receio das mulheres - inclusive desta pesquisadora - de se aprofundar um pouco mais em assuntos tecnológicos, o que, certamente, vai influenciar nas limitações do potencial de transformação. Além do mais, sem o domínio, pelo menos básico, do conteúdo tecnológico - responsável pelo novo cenário -, fica difícil alcançar a amplitude da visão política, econômica, social e cultural necessária para uma intervenção de comunicação a distância, com um entendimento articulado de toda a complexidade envolvida.

Voltando ao panorama de desenvolvimento tecnológico, foi em 1906 que a radiodifusão teve início, a partir da invenção, por Lee De Forest, da válvula radioelétrica - tríodo -, que permitia a ampliação dos sinais elétricos, viabilizando, assim, a audição de sons complexos transmitidos por ondas hertzianas. Foi no Natal desse mesmo ano, que De Forest e Reginald Aubrey Fessenden transmitiram números de cantos e solos de violino, nos Estados Unidos. Mas, é após a I Grande Guerra Mundial que se dá expansão da radiodifusão por todo o mundo. A RCA, primeira grande empresa norte-americana de telecomunicações, é criada em 1919. O alcance da popularidade maciça do rádio em todo o mundo se dá entre as décadas de 30 e 60. A difusão em AM - 
amplitude modulada - tem grande alcance, mas limita a qualidade. Os primeiros emissores em frequência modulada - FM -, que permitem recepção em alta fidelidade, são fabricados pela General Electric, em 1942. Esse alcance sem interferência é melhorado consideravelmente com a transmissão via satélite, a partir de 1958. Recentemente, o sistema digital chega para revolucionar tudo.

A televisão, também utilizando ondas eletromagnéticas para transmitir som e imagem em movimento, tem seu primeiro programa lançado pela BBC, em 1929. A imagem nada mais é do que o resultado da reflexão da luz. A origem da TV, inicialmente eletromecânica, remonta à descoberta do elemento químico selênio, em 1817, por Jacob Berzelius. Depois, em 1873, o inglês Willoughby Smith comprova que o selênio produz uma corrente de elétrons a partir da incidência da luz, transformando a energia luminosa em elétrica. 0 primeiro equipamento só é desenvolvido em 1884, por Paul Gottlieb Nipkow. Mas, é a invenção da célula fotoelétrica, em 1892, que permite converter as subdivisões da imagem em um sinal elétrico. O equipamento de Nipkow é substituído pela televisão eletrônica, em 1923, graças à criação do iconoscópio - um tubo de raios -, pelo russo Vladimir Kosma Zworykin, radicado nos Estados Unidos. É também a partir da década de 1930 que a televisão em branco e preto se expande pela Europa (BBC) e pelo território americano (NBC e CBS). A TV em cores entra em funcionamento no ano de 1954, com um padrão de codificação americano NTSC - compatível com os aparelhos em preto e branco da época, que se seguem ao francês - Secam - e ao alemão - PAL - tornando-se os principais padrões adotados no mundo. As décadas de 50 e 60 são marcadas pela distribuição dos sinais elétricos via satélite e via cabo, propiciando a transmissão de TV instantânea para qualquer lugar do mundo. A TV por assinatura - aquela em que os sinais são transmitidos para quem paga uma taxa mensal - é criada nos Estados Unidos, em meados do anos 1970, expandindo-se para o mundo no início dos anos 90. No Brasil, o mês de agosto de 2011 foi fechado com um total de 11,6 milhões de assinantes ${ }^{47}$.

\footnotetext{
${ }^{47}$ Disponível em: <http://www.teleco.com.br/rtv.asp>. Acesso em: 14 out. 2011.
} 
Há um detalhe muito importante nessa última fase, que é também fato demarcatório no terreno da antiga e nova mídia: a transmissão das ondas eletromagnéticas por dois tipos de sinal elétrico - o analógico e o digital. $\mathrm{Na}$ verdade, o CD foi o primeiro invento a utilizar a tecnologia digital. As músicas, por exemplo, não estão gravadas sequencialmente, o que permite a seleção de qualquer uma delas, além de, em caso de avaria, haver um mínimo de perda. Para um melhor entendimento dessas velozes e profundas inovações, recorreu-se a definições do autor Wilson Dizard Jr. (2000, p. 286, 291, 294) ${ }^{48}$, um estudioso do processo de confluência entre as mídias nova e antiga:

[...] Digital é um método de representação de sinais por um conjunto de valores numéricos diferentes (1s e $0 \mathrm{~s}$ ), ao contrário de uma corrente ou voltagem continuamente variável, como é o caso do analógico. [...] Na mídia antiga, clássica ou tradicional, estão todas as mídias que, na atualidade, já se encontram bem desenvolvidas e disseminadas na sociedade. De uma forma geral, a mídia impressa e a mídia eletrônica são mídias clássicas. Por outro lado, as novas tecnologias da comunicação, basicamente as derivadas do uso intensivo dos computadores e da eletrônica digital - a Internet, por exemplo -, permitiram o aparecimento de uma nova mídia - a Nova Mídia -, com características bem diferentes e que está se desenvolvendo por si mesma, como também afetando as mídias clássicas. [...] A Rede Digital de Serviços Integrados (ISDN, sigla em inglês), é um plano de longo prazo para a transição dos sistemas mundiais de telecomunicações da tecnologia analógica para a digital, permitindo a transmissão integrada de qualquer combinação de voz, vídeo, gráficos e dados através de uma 'tubulação de informação' eletrônica comum. A ISDN é um padrão de programa comum que eliminará as atuais incompatibilidades técnicas entre sistemas de telecomunicações e permitirá a transferência ininterrupta de tráfego entre elas.

A Copa do Mundo de Futebol - realizada na Coréia e no Japão, em meados de 2002, na qual o Brasil sagrou-se pentacampeão - teve os direitos brasileiros

\footnotetext{
${ }^{48}$ DIZARD JR., W. A nova mídia - a comunicação de massa na era da informação. Tradução: Antonio Queiroga e Edmond Jorge. SP: Jorge Zahar Editor. 2000. p. 286/291/294
} 
de exclusividade de transmissão comprados pela Rede Globo, que se mostrou frustrada com o fato de não poder inaugurar a transmissão digital. Na época, a indefinição, pelo governo brasileiro, sobre o padrão a ser adotado - japonês (ISDB), norte-americano (ATSC) ou europeu (DVB) -, desapontou os fabricantes de aparelhos de televisão, já que o índice de vendas caiu. Finalmente em 2006, o então presidente Lula anunciou a escolha pelo padrão japonês ${ }^{49}$, passando o sistema, no ano seguinte, a ser implantado lentamente. Os aparelhos digitais não aposentam os analógicos - que são adaptados através de um dispositivo conectado. "Além do compromisso de investimentos e da transferência de tecnologia, Lula disse a auxiliares que pesou na decisão o padrão japonês permitir maior tempo de adaptação à era digital dos atuais aparelhos de sinal analógico" ${ }^{\circ 0}$.

O impasse verificado no Brasil fornece uma ideia da dimensão políticoeconômica e do jogo de interesses que alcançam as inovações tecnológicas. A disputa que ganha proporções astronômicas é aquela travada entre as companhias telefônicas e a indústria de TV a cabo para obtenção de vantagens na oferta de informação multimídia. Trata-se de um sistema que combina diferentes formatos de conteúdos, como texto, vídeo e som, e instalações de armazenamento, como fitas de vídeo, fitas de áudio, discos magnéticos, discos ópticos -, bem como dos serviços de entretenimento no mercado. A Lei 12.485, de 12/9/2011 “liberou a entrada das companhias telefônicas no mercado de TV a cabo e derrubou a obrigatoriedade de controle de capital nacional nessas operações" ${ }^{21}$. O lançamento do Plano Nacional de Banda Larga (PNBL), em 2010 por Lula, que será detalhado no próximo item desta pesquisa, acirrou ainda mais as disputas políticas e econômicas.

Como se viu, a história da transmissão de TV, basicamente, começou com

\footnotetext{
49 Disponível em: <http://www1.folha.uol.com.br/folha/dinheiro/ult91u105765.shtml>. Acesso em 20 set. 2011

${ }^{50}$ Ibidem

${ }^{51}$ Folha de S.Paulo. Teles vão assumir controle de TVS a cabo. 18.10.11. p. B4
} 
o sistema de ondas, depois satélite, rede de satélites, sistema analógico e, agora, para romper com tudo isso, chega o sistema digital: maior rapidez nas transmissões, sistemas de produção em tempo real, edições sem perda de qualidade e barateamento do sistema, propiciando a expansão. As fibras óticas tecnologia para se orientar e transmitir luz para uso como veículo de comunicação - permitem a compressão dos sistemas, resultando na transmissão de dados ampliados, muito superiores à do cabo coaxial ou à do fio de cobre.

Abrem-se, com isso, enormes perspectivas para o avanço do processo de interatividade, até então muito tímido. 0 princípio da interatividade surge com a televisão, apesar de se caracterizar muito mais por TV reativa, oferecendo a ilusão da participação através do telefone (0800). Ao público de casa era dada a liberdade restrita de telefonar e decidir, por exemplo, sobre o final de um programa. As telenovelas brasileiras, por meio dos grupos de pesquisa, tomam rumos levemente definidos pelo público. Entretanto, o maior controle está com o emissor. A interatividade foi, aos poucos, aumentando, como, por exemplo, no Programa Roda Viva, da TV Cultura, em que o público de casa envia perguntas à pessoa entrevistada, pelo telefone, fax ou e-mail. 0 canal Multishow oferecia a possibilidade de o público decidir o horário da programação de domingo. Hoje, o potencial das novas mídias vem permitindo uma revolução em termos de interatividade e na produção colaborativa multimídia. Mas, este é um assunto a ser mais bem explorado no próximo subitem deste capítulo.

É por isso que Barbero $(1997)^{52}$ destaca em seus estudos o reverso do vazio, mediado pelos meios de comunicação de massa, preconizando um novo sujeito histórico com muito mais conhecimento. E Habermas (1989) ${ }^{53}$ considera possível enfrentar o individualismo gerado pela nova era por meio da ação comunicativa: a internet pode criar outras ágoras para as grandes discussões,

\footnotetext{
52 MARTIN-BARBERO, J. Dos meios as mediações - comunicação, cultura e hegemonia. RJ: Ed. UFRJ. 1997

${ }^{53}$ HABERMAS, Jürgen. Consciência moral e agir comunicativo. Tradução: Guido A. Almeida. RJ: Tempo Brasileiro. 1989
} 
envolvendo novos sujeitos.

Exatamente por levar em conta tais premissas que o percurso discorrido até agora neste capítulo não se deu de forma gratuita ou com o sentido de realizar uma mera contextualização técnica, política, econômica, social e cultural. Trata-se de demonstrar que o complexo midiático está determinando uma nova sociedade, em todos os seus aspectos, vislumbrando, não só para as mulheres, mas para toda a sociedade, novas esferas públicas que podem resultar no exercício cotidiano da democracia direta, propiciando o redesenho de uma intervenção de comunicação a distância.

\subsection{A revolução das mídias digitais}

A revolução das TIC (VIEIRA, 2007) ${ }^{54}$ está ancorada em novas noções de tempo e espaço, um novo modo de ver, perceber e sentir. Paralelamente a essa revolução, que traz novas dinâmicas comunicacionais, acontece a do aprendizado e das novas formas de expressão pessoal e interpessoal. Segundo Barbero $(2008)^{55}$,

[...] vivemos uma época de mudanças profundas no planeta; a internet seria o equivalente ao invento da imprensa; algo parecido seria a invenção da escrita. [...] Não é só um fenômeno

\footnotetext{
${ }^{54}$ As tecnologias da informação e comunicação (TIC) podem classificar-se em três tipos: 1) Tecnologias da informação: equipamentos de computação e seus componentes, os programas de computação (software) e os conhecimentos informáticos. 2) Tecnologia das telecomunicações: os sistemas de telefonia e as transmissões de rádio e televisão. 3) Tecnologia de redes: Internet, os telefones celulares, o sistema de transmissão por cabo, os satélites e outras formas de conectividade por banda larga. A tecnologia da informação utiliza os computadores, que são componentes indispensáveis na sociedade da informação moderna, para processar dados com economia de tempo e esforço. A tecnologia das telecomunicações compreende os telefones, incluindo o fax e a transmissão de sinais de rádio e televisão, com freqüência através de satélites. A tecnologia de redes tem a internet como seu exemplo mais conhecido, mas também tem sido estendido à telefonia celular, à tecnologia de voz por redes, às comunicações por satélites e a outras formas de comunicação, que, todavia, ainda estão sendo pesquisadas. (Fonte: PLOU, Dafne. VIEIRA, Vera. Mulher e Tecnologias: a virtualidade como espaço transformador das relações de gênero. Rede Mulher. SP. 2007. p.32/33.)

${ }^{55}$ Exposições realizadas durante o curso "Novas Sensibilidades: entre urbanias e cidadanias", ministrado na ECA/USP, no período de 15 a 19/9/2008.
} 
técnico, mas político, cultural e social. Espaço e tempo são estruturas de nossa percepção dos sentidos. Uma das barreiras mais fortes entre gerações passa por isso. Uma educação por osmose. Essa nova noção de comunicação leva a um mal estar entre os educadores. Rompe com a pretensão de que o único que sabe é o professor. A escola já não é o lugar de circulação do saber. O Google é melhor do que qualquer professor. Agora, o professor tem um papel muito mais de formulador de problemas, o que é visto como uma ameaça a seu papel de educador. Há a necessidade de que os educadores passem por uma re-educação.

Antes de mais nada, é importante reforçar o conceito das TIC: elas podem ser definidas como meios que utilizam, ao mesmo tempo, as telecomunicações e a tecnologia informática, tendo, na internet, a sua maior expressão. Também é fundamental se desfazer do entendimento antagônico e radical, de seus aspectos positivos ou negativos, já que as TIC são apenas uma realidade atual e irreversível, dentre as etapas do desenvolvimento das formas de transmissão da informação e do conhecimento pela humanidade: vai desde a oralidade, a escrita e as mídias analógicas - como a fotografia, o rádio, a TV e o cinema até chegar às mídias digitais - que representam a mescla de texto, som e imagem, com o grande potencial da interatividade, graças à junção da informática e da internet. (LÉVY, 2005) $)^{56}$

As inovações tecnológicas, principalmente as da informática, configuraram a ressignificação das práticas capitalistas, ou seja, o avanço do processo de globalização, que se acentua com o advento da internet. Logo no início dos anos 1970, os microprocessadores permitiram que as máquinas operatrizes passassem a ser comandadas por processos computacionais. Em seguida, acelerou-se a substituição dos processos de produção e técnicas, com a criação de novos produtos como fax, vídeo, $\mathrm{CD}$, computador, sementes de laboratório (biotecnologia), etc. A grande diferença do significado da palavra globalização está na produção com base na formação de grandes empresas em rede, com atividades planetárias. Exemplo é a compra de componentes em várias partes do

\footnotetext{
${ }^{56}$ LÉVY, P. O que é o virtual? Tradução de Paulo Neves. $7^{\text {a }}$ ed., SP: Editora 34.1996
} 
mundo, cujo processo de fabricação se utiliza de mão-de-obra barata e muitas vezes infantil; a concentração de empresas aonde convém; o controle dos mercados, online, por poucos monopólios mundiais. 0 intenso processo de fusão de empresas, tanto na área produtiva, como na financeira, só foi possível graças à revolução das tecnologias da informação e comunicação. As grandes empresas passam a formar os megaconglomerados, infiltrando-se no sistema financeiro, de informação, de telecomunicações, no âmbito político, etc. Essa prática acentua a subordinação dos países pobres, aumentando o número de pessoas completamente excluídas do sistema. Segundo Hobsbawm (1995, p. 541) ${ }^{57}$,

[...] em suma, o século acabou numa desordem global cuja natureza não estava clara, e sem um mecanismo óbvio para acabar com ela ou mantê-la sob controle. O motivo dessa impotência estava não apenas na verdadeira profundidade e complexidade da crise mundial, mas também no aparente fracasso de todos os programas, velhos e novos, para controlar e melhorar os problemas da raça humana.

Obviamente, toda forma de evolução tecnológica das formas de transmissão implica em inclusão e exclusão. A passagem da oralidade para a escrita exigiu que as pessoas fossem alfabetizadas, que houvesse barateamento do papel, enfim, a formulação e implementação de uma série de políticas públicas. Uma revolução tecnológica traz sempre consigo profundas transformações no campo técnico, político, econômico e sociocultural. Para a massificação (e a democratização) das TIC, as necessidades são ainda maiores e mais caras, principalmente em função da velocidade das alterações. É por isso que a exclusão digital caminha paralelamente à exclusão social. As relações de poder - que envolvem classe, gênero, raça-etnia, sem se esquecer de fatores como a orientação sexual, idade e localização geográfica - produzem complexas desigualdades na dinâmica do acesso e do uso das TIC: entre homens e mulheres,

\footnotetext{
${ }^{57}$ HOBSBAWM, E. Era dos extremos - o breve século XX - 1914-1991. Tradução: Marcos Santarrita. $2^{\mathrm{a}}$ Ed., SP: Cia. das Letras, 1995. p. 541
} 
brancos e negros, pobres e ricos, campo e cidade, Norte e Sul, pessoas com ou sem conexão, dentro da comunidade local, em países soberanos e no âmbito internacional. No Anexo A - Usuários de internet no Brasil - há um detalhamento que demonstra a situação atual em termos de acesso em casa e no trabalho. Apesar da rápida evolução ainda há um longo percurso para uma realidade menos discrepante em termos de brecha digital. Dados da Associação Brasileira de Telecomunicações destacam que o número de 55,4 milhões de acessos em banda larga no Brasil, em novembro de 2011, o que representa um crescimento de $68 \%$ em relação à medição efetuada há um ano.

Visando minimizar a distância entre a população conectada e a sem acesso à internet, o Plano Nacional de Banda Larga (PNBL) foi implementado no final de junho de $2011^{58}$, pela presidenta Dilma Roussef. O PNBL tornou-se alvo de mobilizações contraditórias: de um lado, organizações da sociedade civil lutando por meio da campanha "Banda larga é um direito seu - uma ação pela internet barata, de qualidade e para todos" ${ }^{29}$, de outro, o forte lobby das empresas de telecomunicações junto ao governo federal para oferecer condições exatamente contrárias. Com uma população de cerca de 190 milhões de habitantes, o Brasil possui uma área de $8.514 .876,599 \mathrm{~km}^{2}$, que se divide em 26 estados e o distrito federal, contando com 5.564 municípios. Tamanha amplitude em um país em pleno crescimento, considerado a $7^{a}$ maior economia do mundo e a maior da América Latina, só faz acirrar a disputa pelos serviços de banda larga país afora até 2014, ano de realização da Copa do Mundo de Futebol da Fifa. Sem contar que a inclusão social propiciada desde a primeira gestão Lula ocasionou o aparecimento de uma nova classe C, cuja demanda de consumo vem ultrapassando em muito a oferta de mercado existente nos diversos segmentos.

\footnotetext{
${ }^{58}$ O governo brasileiro fechou, em 30/6/11, acordo com as concessionárias de telefonia fixa Telefônica, Oi, Sercomtel e CTBC, para que o serviço de banda larga comece a ser ofertado em 90 dias, cobrindo todos os municípios brasileiros até 2014. Pelo acordo, é exigido que as empresas ofereçam um plano com velocidade de $1 \mathrm{Mbps}$ (megabit por segundo), por $\mathrm{R} \$ 35,00$, valor este que é metade daquele cobrado atualmente, mas muito acima dos R\$15,00 prometidos no início das discussões governamentais. (Fonte: Folha de S. Paulo, 1/7/11. Caderno Mercado. Governo e operadoras fecham plano de internet - versão digital: http://www1.folha.uol. com.br/fsp/mercado/me0107201123.htm)

${ }^{59}$ Disponível em: <www.bandalarga.org.br>. Acesso: 12 set. 2011.
} 
Em editorial do jornal Folha de S. Paulo, de 20/6/11, intitulado "Banda mais larga", é defendida a opinião de que "regulação eficiente, competição privada e investimentos do governo são a melhor combinação para destravar a banda larga”. Esse argumento é justificado no texto, a partir do entendimento de que

[...] a Lei Geral de Telecomunicações, de 1997, está ultrapassada, pois não lida com novas tecnologias nem considera o acesso à internet um serviço sujeito a contratos de concessão pública. É preciso incentivar a competição, com compartilhamento das redes privadas a custo baixo, o que reduziria a barreira de entrada de novos provedores. Metas de universalização, tal como foi feito com a telefonia fixa nos anos 1990, também seriam úteis.

Ana Veloso $(2011)^{60}$, representante da sociedade civil no Conselho Curador da Empresa Brasil de Comunicação (EBC) e atual doutoranda da Universidade Federal de Pernambuco, discorda do estímulo à privatização de um bem que é público, considerando que

[...] o provimento deve ficar por conta do Estado. A regulação deve ser efetivada para garantir que o acesso ao serviço não se dê, somente, pela via econômica, mas, como um direito dos/as cidadãos/cidadãs. É preciso que a sociedade brasileira possa ser beneficiada sem ter que pagar altas contas, como sempre ocorreu com os serviços de telecomunicações no país. A banda larga deve ter, no mínimo, 4giga, com uma possibilidade de compartilhamento a um custo mínimo, como de água e de energia elétrica para pessoas de baixa-renda, para viabilizar a estrutura do serviço e universalizar o acesso. [...] É por isso que, no Brasil, uma política pública de banda larga abrangente e de qualidade, é condição fundamental para que as mulheres possam atuar ainda mais como produtoras de conteúdo para diversas plataformas e mídias. $O$ acesso às tecnologias não significa, imediatamente,

\footnotetext{
${ }^{60}$ Entrevista fornecida a esta doutoranda para o artigo de sua autoria $A$ estreita visão da banda larga no Brasil, publicado em junho de 2011. Disponível em: < $\underline{\text { http://www.genderit.org/es/feminist-talk/estreita-vis-o- }}$ da-banda-larga-no-brasil > . Acesso em: 2 ago. 2011.
} 
produção com viés crítico ou revolucionário. Todavia, é preciso que o Estado brasileiro seja capaz de implementar uma política que universalize o acesso com custos mínimos para toda a população. Dessa forma, as mulheres, como parte dos segmentos marginalizados dos processos da comunicação, no país, poderão ter suas ações potencializadas com o envio de dados/informações e o compartilhamento das suas produções na rede. Portanto, para que as mulheres tenham mais possibilidades de comunicação e de organização.

O Fórum Nacional pela Democratização da Comunicação realizou, na cidade do Rio de Janeiro, no final de maio deste ano, o seminário Marco Regulatório: Propostas para uma Comunicação Democrática, ocasião em que diversas entidades presentes endossaram a necessidade de regulamentação de todo o setor de comunicações, "dando conta do processo de convergência e estabelecendo regras que afirmem a liberdade de expressão e o direito à comunicação de toda a população, buscando garantir a pluralidade e a diversidade informativa e cultural".

A $1^{\text {a }}$. Conferência Nacional de Comunicação (Confecom), realizada em Brasília, de 14 a 17 de dezembro de 2009, reunindo 2 mil pessoas entre representantes do governo, da sociedade civil e do empresariado, foi celebrada por ser um fato inédito na história brasileira. Além disso, tratava-se de um evento da maior importância para o avanço do processo democrático, que inclui o direito à comunicação, especialmente na era digital. E foi exatamente com essa preocupação que, das 672 propostas aprovadas, 144 delas abordaram a questão das TIC; 84 citaram a perspectiva de gênero e diversidade; 13 focaram especificamente a questão da violência contra a mulher; 39 não deixaram de ter relação com a violência contra a mulher; e 7 estavam relacionadas à questão das TIC e da violência contra a mulher. O Anexo B - Resumo da Confecom relaciona também as propostas específicas interligadas às TIC e violência contra a mulher, principal foco de inter-relação desta tese. Computando-se as conferências no âmbito municipal, estadual e federal, o processo da Confecom contou com a participação de 30 mil pessoas, o que contribuiu para ampliar o 
entendimento da comunicação como um direito humano fundamental para o desenvolvimento econômico e social.

Essa mobilização evidencia que um PNBL abrangente e democrático é aspiração, há décadas, da sociedade civil. Obviamente, tal política pública esbarra na necessidade pungente de um marco regulatório para o setor. Esse debate tem sido distorcido pelos poderosos da mídia, com o argumento de censura governamental. Segundo texto de abertura do manifesto das entidades integrantes da campanha Banda larga é um direito seu, a internet rápida brasileira é

[...] ruim, cara e para poucos. Essa situação precisa mudar. É indiscutível que a banda larga configura, hoje e cada vez mais, um meio para a realização de direitos fundamentais, tais como direito à comunicação, direito de participação política, direito de ter voz e existir ao mundo. Em razão disso, não há mais tempo a perder: o Estado precisa garantir que todas as pessoas, independentemente da condição socioeconômica ou da localidade, tenham acesso a um serviço de banda larga de qualidade, barato e rápido. Para isso, apresentamos um manifesto com princípios que devem balizar as ações do Executivo e do Legislativo, sejam elas de regulamentação, regulação ou de políticas públicas para o setor. ${ }^{61}$

Apesar das limitações no redesenho de um Brasil amplamente conectado, há que se reconhecer o potencial da interatividade, possibilitando o diálogo instantâneo e a produção coletiva de conhecimento, preceitos básicos do objeto desta pesquisa de doutorado, no sentido de avançar nas formas de atuação para a desconstrução social de relações de gênero desiguais. Como consequência, acerta-se o alvo da raiz do problema que se materializa de forma injusta e dramática no cotidiano das pessoas, cujas relações inequitativas de poder se traduzem, entre outros, em altos índices de violência doméstica ou na diferença salarial na mesma função, mesmo com um número maior de anos de estudo pela

\footnotetext{
${ }^{61}$ Disponível em: <www.bandalarga.org.br> $>$. Acesso: 12 set. 2011.
} 
mulher.

\subsubsection{A interatividade: o maior potencial da internet}

A interatividade propiciada pelas mídias digitais leva os movimentos sociais a revisarem o conteúdo de suas propostas de transformação. Há a necessidade de se alicerçar em novas narrativas eletrônicas para que as bandeiras de luta não se ancorem em mais uma alternativa do mundo virtual incapaz de captar minimamente o universo de pessoas interligadas em rede. Para o professor José Manuel Moran (2011) ${ }^{62}$,

[...] a navegação precisa de bom senso, gosto estético e intuição. Bom senso para não deter-se, diante de tantas possibilidades, em todas elas, sabendo selecionar, em rápidas comparações, as mais importantes. A intuição é um radar que vamos desenvolvendo ao "clicar" o mouse nos links que nos levarão mais perto do que procuramos. A intuição nos leva a aprender por tentativa, acerto e erro. Às vezes, passaremos bastante tempo sem achar algo importante e, de repente, se estivermos atentos, conseguiremos um artigo fundamental, uma página esclarecedora. 0 gosto estético nos ajuda a reconhecer e a apreciar páginas elaboradas com cuidado, com bom gosto, com integração de imagem e texto.

De acordo com Dorfmann (2003) ${ }^{63}$, para se avaliar um ambiente virtual no que tange a sua proposta político-pedagógica, deve-se considerar os atributos que estimulam a navegação, tais como conveniência: facilidade para se obter o que se deseja; confiabilidade: confiança do usuário em relação ao portal; acessibilidade: facilidade com que o usuário acessa o portal; atualização: periodicidade com que os conteúdos são atualizados; variedade de serviços: se o portal oferece exatamente o que o usuário necessita; personalização: se o portal utiliza a linguagem do usuário; interatividade: possibilidade que o portal oferece

\footnotetext{
${ }^{62}$ MORAN, J. M. Como utilizar a internet na educação. Também disponível em: <www.scielo.br>. Acesso em: 30 set. 2011.

${ }^{63}$ DORFMANN, P. F. Atributos favoráveis à motivação para visitação de um site: estudo de um portal educacional. 2003. 93p. Dissertação (Mestrado em Administração). Escola de Administração. PPGO, UFRGS. Porto Alegre. 2003
} 
de interação entre usuários; navegação: facilidade do usuário em acessar as diversas páginas do portal; conteúdo: profundidade do assunto desenvolvido pelo portal; design: impressão gráfica causada ao usuário. Como pondera e destaca Costa $(2011)^{64}$

[...] a interatividade técnica, todavia, já aparece como característica de certas mídias desde a criação do telégrafo e do telefone com os quais foi possível o diálogo simultâneo e sincrônico. No entanto, as mídias digitais tornaram a interatividade uma de suas principais características - os computadores foram concebidos para manterem os usuários em num estado de prontidão, capazes de ativar funções através de áreas ou botões. Interligados para o trabalho coletivo ou para envio e recebimento de mensagens, os computadores foram integrados em redes que têm na interatividade uma de suas mais decantadas potencialidades.

Ao focar a utilização das redes sociais na defesa das chamadas "minorias", vale a pena discorrer, primeiramente, sobre um artigo provocativo, intitulado Parceiros não comunicativos: análise da mídia dos movimentos sociais e os educadores radicais, de John D. H. Downing (2010, p. 52) ${ }^{65}$, fundador e professor do Global Media Research Center do College of Mass Communication and Media Arts da Southern Illinois University Carbondale, nos Estados Unidos. No artigo, este autor

[...] se concentra principalmente no potencial das faculdades e universidades, incluindo o universo além dos contextos educativos, na construção de interações construtivas nos chamados cinco cantos do firmamento: as análises da mídia, o ativismo da mídia, a mídia arte, as profissões na indústria da mídia e os responsáveis pelas políticas de mídia.

\footnotetext{
${ }^{64}$ COSTA, M. C. C. Interatividade - entre graus de liberdade e intencionalidades narrativas. p. 8-9. Também disponível em: < http://www.alaic.net/VII_congreso/gt/gt_1/GT1-P26.html>. Acesso em: 30 set. 2011.

65 DOWNING, J. D. H. Revista Matrizes, volume 3, no.2, 2010, p. 52. Também disponível em:

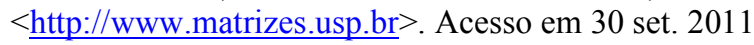


Há diversas definições e análises que interessam a esta pesquisa-ação, na medida em que esclarecem conceitos e reforçam as incidências estratégicas necessárias no foco do trabalho direcionado para o campo da comunicação e do feminismo. São merecedores de destaque especial três cantos no pentagrama sugerido pelo autor - as análises da mídia, o ativismo da mídia e os responsáveis pelas políticas de mídia, na medida em que devem dialogar visando estancar a separação existente entre teoria e prática. Segundo Dowing (ibidem, p. 58) ${ }^{66}$ :

[...] A divisão do trabalho entre pensadores e criadores está
gravada em nossa história e no tecido social, e afeta diversas
outras atividades além da mídia. [...] Hoje essas divisões sufocam
o verdadeiro potencial de programas de educação de mídia,
impedindo um diálogo engajado, e não mais superficial, entre os
cinco pontos da bússola da mídia. [...] o vínculo entre a análise e
a prática oferece uma importante abertura para a proliferação
das facilidades da mídia dos movimentos sociais, suas
experiências e vivências. Não deveríamos ficar satisfeitos com
os sistemas midiáticos que temos, nem ignorar as questões
ambientais, questões de 'raça' e etnia, gênero, classe social,
pobreza global e guerra

Há outro aspecto abordado pelo autor sobre o que algumas mídias digitais vêm dando importância e chamando de "a cauda longa" da mídia, tratando-se de uma mudança de visão, já que nas mídias analógicas não mereciam atenção: mídia alternativa, mídia dos cidadãos, mídia da comunidade, mídia tática, mídia independente, mídia de contrainformação, mídia participativa, mídia do terceiro setor, mídia dos movimentos sociais. Para Downing (ibidem, p. 52-53) ${ }^{67}$, todas as terminologias têm aspectos positivos e negativos, demonstrando preferência pela mídia dos movimentos sociais, ponderando, entretanto, sobre a dificuldade de definir tais práticas, já que fogem às formas, estruturas e aos gêneros organizacionais da mídia convencional.

\footnotetext{
${ }^{66}$ Ibidem. p. 58

${ }^{67}$ Ibidem. p. 52-53
} 
Mídia alternativa: é uma designação completamente insossa, já que tudo é uma alternativa para alguma coisa.

Mídia dos cidadãos: é um termo que reconhece o campo magnético criado pela cidadania cultural.

Mídia da comunidade: penso que esse termo ainda é assombrado pelo significado nebuloso e róseo implícito na palavra comunidade.

Mídia tática: é o termo favorecido pelo ativista de internet e escritor Geert Lovink (2002), apesar de sua explicação do termo ser quase uma antidefinição: ... um termo deliberadamente escorregadio, uma ferramenta para criar zonas de consenso temporário com base em alianças inesperadas... hackers, artistas, críticos, jornalistas e ativistas...

Mídia Independente: é o termo perfeito por Herman e Chomsky para denominar a mídia de notícias não corporativa, não estatal e não religiosa.

Mídia de contrainformação: originado com Pio Baldelli (1977), mas ainda bem atual (Vitelli e Rodriguez Esperon, 2004), e também muito marcado dentro da área do jornalismo, na qual a palavra informação é usada como sinônimo de notícia.

Mídia participativa: é um termo bastante utilizado em projetos do Terceiro Mundo, e em sua concepção original significava que as pessoas afetadas por esses projetos deveriam ter um papel ativo na elaboração dos mesmos, e em seguida também deveriam avaliar os seus progressos (Mefalopulos, 2003).

Mídia do terceiro setor: denotando a mídia na esfera da ação social e voluntária, é um termo algumas vezes utilizado em discussões na Europa. Em outras palavras, a parte do espectro midiático que não tem patrocínio comercial, governamental nem institucional.

Mídia dos movimentos sociais: é o termo que eu tendo a preferir, visto que o termo ancora esses projetos de mídia em grandes e pequenos movimentos sociais, construtivos e repressivos, e todos os anteriores. [...]

A partir das breves definições acima, esta tese procurará focar no entrelaçamento das teorizações de mídia dos movimentos sociais e mídia tática, considerando-se serem estas as duas terminologias que mais se aplicam ao objeto de pesquisa voltado para a comunicação e o feminismo. De acordo com proposição de Downing, é exatamente pela importância que a mídia dos movimentos sociais alcança a partir do advento das redes sociais - YouTube, 
MySpace, Facebook e outras -, que é necessário considerar o pentagrama "na interface potencial entre o ativismo de mídia e os educadores de mídia", para desenvolver

[...] uma esquizofrenia construtiva, uma habilidade para jogar o jogo comercial quando necessário para sobreviver, mas também para ao mesmo tempo, ter a capacidade de manter uma constante distância mental do jogo em si, e continuar tendo um anseio persistente de mudar a situação. (DOWNING, 2010, p.52) ${ }^{68}$

\subsubsection{Ambientes virtuais}

Para exercer o papel de "formulador de problemas" ou de "provocador cognitivo" ${ }^{\text {, }}$, quem atua no ensino formal ou não formal, com uma proposta de comunicação a distancia, conta com recursos tecnológicos atrativos, como as diversas ferramentas para utilização em ambientes virtuais, que possibilitam uma interação bidirecional e o desvelar da criatividade e potencial. Para Almeida $(2002)^{70}$ :

Ambientes virtuais de aprendizagem são sistemas computacionais geralmente acessados via internet, destinados ao suporte de atividades mediadas pelas TIC (Tecnologias da Informação e Comunicação) e por um professor-orientador. Permitem integrar múltiplas mídias e recursos e apresentar informações de maneira organizada, desenvolver interações entre pessoas e objetos de conhecimento, elaborar e socializar produções.

Entre essas ferramentas dos ambientes virtuais, estão os meios de comunicação online como o correio eletrônico, Skype, fórum, chat, a

\footnotetext{
${ }^{68}$ Ibidem. p. 52

${ }^{69}$ Termo utilizado pela profa. Stela Piconez, em sala de aula, no transcorrer da disciplina Aprendizagem Cooperativa Apoiada em Tecnologias da Internet: novos desafios, novas competências, no $2^{\circ}$ sem/2008, na Faculdade de Educação da USP.

${ }^{70}$ ALMEIDA in VIEIRA et al., 2002. Pesquisa integrada: aspectos que orientam o desenvolvimento de ambientes virtuais (IX Congresso Internacional de EaD/ABED).
} 
videoconferência (ver Glossário, ao final) e as chamadas redes sociais (YouTube, MySpace, Orkut, Twitter, Facebook). Nesta parte da tese, a proposta é a de abordar a utilização das redes sociais na defesa das "minorias", ferramenta esta cuja característica principal é a de proporcionar o aumento do diálogo. De acordo com Torres (2008, p. 257 ${ }^{71}$,

\begin{abstract}
As redes sociais digitais são o resultado das interações entre indivíduos, tecnologias e fluxos informativos, e nelas ocorre a manifestação de uma sociedade planetária que se expressa em um espaço público desterritorializado, estabelecendo uma interconexão interpessoal universal, sem mediação governamental, com liberdade de expressão e de associação com base em parâmetros partilhados por todos.
\end{abstract}

Essas redes sociais são essenciais para uma estratégia feminista de intervenção comunicacional a distância, pois elas se tornaram o ancoradouro de produção e difusão independentes, consolidando uma cultura de participação que expressa, de forma inovadora, valores e atitudes primordiais à evolução da cidadania plena. Dentre essas redes sociais $^{72}$, as que mais se popularizam são: 0 YouTube, "um site que permite que seus usuários carreguem e compartilhem vídeos em formato digital". Foi fundado em 2005 pelos engenheiros Chen e Jawed Karim, funcionários da PayPall, um site financeiro voltado a transferência de fundos. No final de 2006, o YouTube foi adquirido pelo Google. O MySpace possui a particularidade de ter um sistema interno de email, fóruns e grupos. Caracteriza-se por "uma rede interativa de fotos, blogs e perfis de usuário. Foi criada em 2003. É a segunda maior rede social dos Estados Unidos e do mundo com mais de 110 milhões de usuários". É a rede social de maior uso por músicos em função de hospedar MP3 (sistema de compressão de áudio em até 75\%). A rede MySpace foi vendida pela News Corp. (conglomerado de Rupert Murdoch,

\footnotetext{
71 TORRES, J. C. Cyborgcracia: entre a gestão digital dos territórios e as redes sociais digitais. In: Do público para as redes - A comunicação digital e as novas formas de participação social (org: Massimo Di Felice). Difusão Editora. São Caetano do Sul/SP. 2008. p. 257

${ }^{72}$ Disponível em: <pt.wikipedia.org>. Acesso em: 30 set. 2011.
} 
que inclui o "Wall Street Journal", em 29/6/11, para a empresa de publicidade on-line Specific Media, por USD 35 milhões, valor irrisório perto dos USD580 milhões pagos em 2005. No artigo publicado no jornal Folha de S. Paulo, intitulado "Murdoch vende site MySpace e perde mais de USD 500 milhões", de 30/6/11, p.B9, destaca-se que "a rede tem hoje 35 milhões de usuários nos EUA, ante os 170 milhões do site de Mark Zuckerberg [Facebook]".

A comunidade virtual Orkut foi criada em 2004, para que as pessoas criassem novas amizades e mantivessem relacionamentos. 0 engenheiro turco do Google, Orkut Büyükkokten, foi o inventor da rede social que encontrou no Brasil o maior número de usuários - 23 milhões. Desde 2006, o sistema permite que os usuários criem contas sem haver a necessidade de convite. A hegemonia do Orkut foi quebrada pela proliferação do Facebook, lançada em 2004, por Mark Zucherberg, Dustin Moskovitz, Eduardo Saverin e Chris Hughes, ex-estudantes da Universidade Harvard. Criado inicialmente para unir estudantes de universidades e escolas americanas, em 2006, passou a congregar quaisquer usuários com 13 anos de idade ou mais. A disputa pela invenção, entre Mark Zucherberg e o brasileiro Eduardo Saverin, foi tema de filme ganhador da $83^{a}$ edição do Oscar, em 2011, nas categorias de melhor roteiro, melhor roteiro adaptado e melhor trilha sonora original. "A Rede Social”, filme de David Fincher, bateu recordes de bilheteria ao juntar em seu enredo ingredientes de sucesso, dinheiro, ambição e traição. Em fevereiro de 2011, o Facebook atingiu a primeira colocação no ranking dos sites mais acessados do mundo, com 590 milhões de visitas e um alcance global de 38,1\%, de acordo com o Ad Planner Top 1000 Sites. Segundo dados do site www.wbibrasil.com.br, o número de usuários no mundo já chegou a 700 milhões, sendo que

[...] um dos grandes responsáveis por esta popularização é o Brasil, a terra do Orkut. Segundo dados da Socialbakers, empresa de estatísticas especializada nos índices do Facebook, o Brasil foi responsável pela inscrição de 1,9 milhão de usuários em maio, um crescimento de $11,37 \%$ em relação ao mês anterior. 0 número de usuários do Facebook no Brasil chegou a um total de 19 milhões, e se aproxima dos 32 milhões de 3 usuários do Orkut, a rede social 
do Google.

Como se vê, torna-se estratégica a utilização de tais ferramentas para fins de intervenção comunicacional, levando em conta tanto seu potencial tecnológico, quanto os aspectos de atratividade que gerou e continua gerando no público brasileiro. O resultado da utilização desta ferramenta pode ser direcionado para focos fundamentais no processo de amplificação e articulação dos movimentos sociais visando à transformação pessoal: maior socialização, troca e produção de informação e conhecimento. Sem dúvida, são ferramentas que se mostram potencializadoras da habilidade de compartilhamento da responsabilidade dos próprios processos de transformação pessoal e interpessoal em uma intervenção de comunicação a distância. Sua utilização irá promover o avanço de um dos grandes desafios da educação formal e não-formal que é o de deixar de meramente transmitir conhecimento. Como diz Paulo Freire (1989, p. $\left.12^{73}\right)$, a ação educadora “deve ser a de comunicação, se quiser chegar ao homem [e à mulher], não ao ser abstrato, mas ao ser concreto inserido em uma realidade".

Com isso, criam-se, de acordo com Paulo Freire (1999, p. 52, 57, 85, 98-99 e $109)^{74}$

[...] as possibilidades para a sua própria produção ou a sua construção. [....] Aprender para nós é construir, reconstruir, constatar para mudar, o que não se faz sem abertura ao risco e à aventura do espírito. [...] 0 mundo não é. 0 mundo está sendo. Como subjetividade curiosa, inteligente, interferidora na objetividade com que dialeticamente me relaciono, meu papel no mundo não é só o de quem constata o que ocorre, mas também o de quem intervém como sujeito de ocorrências. O exercício da curiosidade convoca a imaginação, a intuição, as emoções, a capacidade de conjecturar, de comparar, na busca da perfilização do objeto ou do achado de sua razão de ser. [...] Um dos saberes

\footnotetext{
${ }^{73}$ FREIRE, P. Extensão ou Comunicação? Tradução: Rosisca Darcy de Oliveira. SP. Paz e Terra. $2^{\mathrm{a}}$ ed. p.12

${ }^{74}$ FREIRE, P. Pedagogia da Autonomia - Saberes necessários à prática educativa. SP: Paz e Terra. 20a.edição. 1996. p. 52, 77, 85, 98, 99 e 109.
} 
fundamentais à minha prática educativo-criativa é o que me adverte da necessária promoção da curiosidade espontânea para a curiosidade epistemológica. [...] Afinal, o espaço pedagógico é um texto para ser constantemente 'lido', interpretado, 'escrito' e 'reescrito'.

Dentre as formas de utilização das redes sociais como ferramenta estratégica de comunicação a distância pode-se citar como exemplos a criação de comunidades, fechadas ou abertas de temas pertinentes à agenda feminista; a busca de perfis para início de discussões sobre, por exemplo, sexualidade, Aids, drogas, etc.; a busca de perfis de pessoas que se dedicam a temas correlatos; a busca de arquivos correlatos a assuntos de interesse, através de links externos postados em comunidades.

É possível ampliar enlaces e conexões para além da zona de influência física e geográfica, relacionando-se com redes de indivíduos ou grupos, para o trabalho de promoção da agenda feminista. As TIC contribuem para "enredar" grupos com interesses similares, que de outra maneira não entrariam em contato. Cada grupo desenvolve seu próprio trabalho, mas está consciente de que esse trabalho participa de uma iniciativa mais ampla; por conseguinte, as atividades que vinculam as pessoas e que contribuem para a criação de alianças podem ser interpretadas como meios ou instrumentos de mudanças positivas. Um novo tempo, um novo espaço: é preciso aproveitar os aspectos positivos do panorama que se configura de forma irreversível, visando a alcançar a cidadania global e a evitar a 'desintegração globalizante’. 
As teorias feministas e a violência contra a mulher 
Ninguém nasce mulher, torna-se mulher.

Simone de Beauvoir

O melhor modo de avaliar o grau de civilização de um povo, é analisando a situação da mulher.

Fourier 


\subsection{Relações de gênero, movimento feminista e movimento de mulheres}

Faz-se necessário abordar as diferenças e semelhanças existentes entre as propostas do movimento feminista e do movimento de mulheres, para se alcançar o entendimento dos aspectos em que a agenda de ambos se fortalece na medida em que se torna única, tornando-se este um fator fundamental para uma intervenção mais incisiva na mídia.

Ao mergulhar nas peculiaridades desses dois movimentos, depara-se com um conceito intrinsecamente conectado a eles: relações sociais de gênero. Simone de Beauvoir pode ser considerada uma precursora nos estudos de gênero - mesmo sem utilizar este termo -, com seu livro O Segundo Sexo, lançado em 1949, que repercutiu e causou polêmica em várias partes do mundo. Uma das frases da célebre filósofa contida no livro é permanentemente citada: ninguém nasce mulher, torna-se mulher.

Desde os anos 1970, o movimento feminista tomou grande impulso, radicalizando a luta pela igualdade de gênero, estratégia de sucesso para pautar a importância da temática no mundo. Foi na década de 1970 que se incorporou a expressão "relações de gênero", até hoje considerada complexa e confusa por muita gente. Da mesma forma, as feministas brasileiras, com base na contribuição de Paulo Freire, aprimoraram uma metodologia - junto com a luta dos Movimentos Populares existentes há tempos - “através dos grupos de autoconsciência, para que as mulheres trouxessem à tona as inúmeras variáveis desta opressão social sofrida pela mulher "por ser mulher"” (VIEZZER, 1997,p. 11). ${ }^{75}$ Buscando a revisão das formas de organização e convívio na sociedade, o movimento de mulheres passou a lutar para alterar a condição de opressão do sexo feminino pelo masculino.

Para Laqueur (2001), até o final do século XVII, em termos políticos e epistemológicos, só era aceita a categoria “masculina”. A inclusão da categoria “feminina" entendida como outro sexo oposto e incomensurável começa a ser

\footnotetext{
${ }^{75}$ VIEZZER, M. Paulo Freire e as Relações Sociais de Gênero. Informativo Cunhary/Rede Mulher. SP. no.24. jul-ag/97. p.11
} 
aceita então pelas várias correntes da revolução científica, ou seja, pelo baconianismo, mecanicismo cartesiano, pela epistemologia empírica e síntese newtoniana, as quais "haviam destruído radicalmente a forma galênica de compreender o corpo com relação ao cosmo"76. Laqueur (2001, p. 244 e 245 $)^{77}$ ressalta que

[...] Roussel, Moreau e Cabinis, os mais proeminentes antropólogos morais da Revolução Francesa, escreveram sobre questões de família e de gênero, argumentando que as diferenças corporais exigiam diferenças sociais e legais do novo Código. As diferenças eram propostas em conflito. Susanna Barrows mostrou que os medos originados da Comuna de Paris e das possibilidades políticas abertas pela Terceira República criavam uma antropologia física de diferença sexual extraordinariamente elaborada, para justificar a resistência à mudança. Na Inglaterra o movimento feminino pelo sufrágio, na década de 1870 , suscitou reações semelhantes: as mulheres eram consideradas criaturas que, por várias razões e sob muitos aspectos, as mesmas que desvalorizavam as raças mais escuras, eram incapazes de assumir responsabilidade cívica. [...] Dois sexos incomensuráveis são resultado de práticas discursivas, mas só se tornam possíveis dentro de realidades sociais às quais essas práticas dão sentido. [...] Esse desenvolvimento histórico é parte do que eu considero ser a criação discursiva da diferença. Em termos mais amplos, como dizia Joan Landes, 'uma ordem ideologicamente sancionada de diferenças de gênero e esferas públicas-privadas... fundamenta a geografia institucional e cultural da nova esfera pública'.

Em um trecho conclusivo, Laqueur (2001, p. 254) destaca que

[...] o desejo tinha uma história e o corpo feminino era distinguido do masculino, à medida que as grandes transformações da sociedade européia entre os séculos XVII e XIX faziam uma pressão insuportável contra as antigas visões do corpo e de seus prazeres. Uma biologia da hierarquia cósmica deu lugar

\footnotetext{
${ }^{76}$ LAQUEUR, T. Inventando o Sexo - Corpo e gênero dos gregos a Freud. RJ: Ed. Relume Dumará, 2001. p. $244-245$

${ }^{77}$ Ibidem. p. 254
} 
à biologia da incomensurabilidade, baseada no corpo, onde a relação do homem para a mulher, como das maçãs para as laranjas, não era considerada de igualdade ou desigualdade e sim de diferença. Isso exigia interpretação e tornou-se a arma da luta cultural e política.

Joan Scott, professora de Ciências Sociais no Instituto de Estudos Avançados em Princeton, historiadora e militante feminista norte-americana, é autora de um texto originalmente publicado em 1988 sob o título Gender on the Politics of History, traduzido, pela primeira vez, para o português em 1990 (Gênero: uma categoria útil de análise histórica), quando passou a ser mais amplamente utilizado em trabalhos acadêmicos e na prática da educação nãoformal desenvolvida pelos movimentos sociais brasileiros. Nele, Scott destaca o significado de gênero por meio de uma composição de quatro elementos que operam simultaneamente:

[...] 0 núcleo da definição repousa numa conexão integral entre duas proposições: (1) o gênero é um elemento constitutivo das relações sociais baseadas nas diferenças percebidas entre os sexos e (2) o gênero é uma forma primária de dar significado às relações de poder. [...] 0 gênero implica quatro elementos interrelacionados: em primeiro lugar os símbolos culturalmente disponíveis que evocam representações simbólicas (e com frequência contraditórias) [...] Em segundo lugar, conceitos normativos que expressam interpretações dos significados dos símbolos, que tentam limitar e conter suas possibilidades metafóricas. Esses conceitos estão expressos nas doutrinas religiosas, educativas, científicas, políticas ou jurídicas e tomam a forma típica de uma oposição binária fixa, que afirma de maneira categórica e inequívoca o significado do homem e da mulher, do masculino e do feminino. [terceiro aspecto] 0 desafio da nova pesquisa histórica consiste em fazer explodir essa noção de fixidez, em descobrir a natureza do debate ou da repressão que leva à aparência de uma permanência intemporal na representação binária de gênero. Esse tipo de análise deve incluir uma concepção política bem como uma referência às instituições e à organização social. [...] 0 quarto aspecto do gênero é a identidade subjetiva. Concordo com a ideia da antropóloga Gayle 
Rubin de que a psicanálise fornece uma teoria importante sobre a reprodução do gênero, uma descrição da 'transformação da sexualidade biológica dos indivíduos enquanto passam por um processo de enculturação'. ${ }^{78}$

A reflexão sobre o cerne da definição de $\operatorname{Scott}^{79}$ de que "o gênero é uma categoria social imposta sobre um corpo sexuado" leva ao discernimento das nuances existentes no percurso das posições antagônicas do ser feminino e do ser masculino. Na concepção de Fagundes $\left(2001\right.$, p. 16) ${ }^{80}$,

[...] dada a natureza social do conceito de gênero e de identidade, ambos estão afinados aos estereótipos culturais, fundamentados nas diferenças genitais feminina e masculina que os transcendem. Entretanto, entre esses dois modelos ou pólos feminino e masculino - há uma infinidade de conjugações de níveis e intensidade, que extrapolam os espaços definidos pela sociedade para serem ocupados pelas mulheres e pelos homens.

Ao discorrer sobre a célebre frase de Simone de Beauvoir, descrevendo-a como "Alguém não nasce e sim se torna uma mulher... É a civilização como um todo que produz essa criatura”, duas outras autoras (Jaggar e Bordo, 1997) ${ }^{81}$, trazem uma reflexão aprofundada sobre o seu sentido, frisando que

\footnotetext{
${ }^{78}$ Disponível em: <http://www.archive.org/details/scott_gender>. Acesso: 27 out. 2011

Descrição:
}

SCOTT, J. W. "Gênero: uma categoria útil de análise histórica”. Educação \& Realidade. Porto Alegre, vol. 20, no 2,jul./dez. 1995, pp. 71/99.

Revisão de Tomaz Tadeu da Silva a partir do original inglês (SCOTT, J. W.. Gender and the Politics of History. New York: Columbia University Press, 1988. PP. 28-50.), de artigo originalmente publicado em: Educação \& Realidade, vol. 15, no 2, jul./dez. 1990. Tradução da versão francesa (Les Cahiers du Grif, $n^{\circ}$ 37/38. Paris: Editions Tierce, 1988.) por Guacira Lopes Louro.

Primeira versão americana: SCOTT, J. W.. "Gender: A Useful Category of Historical Analysis". The American Historical Review, vol. 91, nº 5. (Dec., 1986), pp. 1053-1075.

${ }^{79}$ Disponível em: <http://www.archive.org/details/scott_gender>. Acesso: 27 out. 2011

${ }^{80}$ FAGUNDES, T.C.P.C. Educação e Construção da Identidade de Gênero. In: Ensaios sobre Gênero e Educação. (org. pela mesma). Salvador: UFBA, 2001. p. 16.

${ }^{81}$ JAGGAR, A.M.; BORDO, S.R. Gênero, Corpo, Conhecimento. Tradução: Britta Lemos de Freitas. Rio de Janeiro: Ed. Rosa dos Tempos, 1997, p. 233-234. 
[...] o gênero é uma categoria, um meio de fazer distinções entre as pessoas, classificando-as com base em traços sexuais. [...] Ele é construído e reconstruído dentro de uma estrutura que interage com fatores biológicos; mas não é imutavelmente controlado e contido por essa biologia. Embora cada um de nós venha ao mundo com certas características - órgãos sexuais, cor dos olhos, textura dos cabelos, equilíbrios e desequilíbrios hormonais, talvez até atitudes cognitivas, habilidades e tendências agressivas - sua configuração e avaliação são consequiências das condições sociais e históricas. [...] A maneira como alguém é estimado, isto é, seu prestígio, não é algo previamente condicionado de forma determinista ou mecanicista, mas é, ao contrário, uma consequência de fatos históricos moldados pela atuação humana.

Considera-se, então, que as relações de gênero, por milênios, vêm sendo construídas socialmente, aceitas culturalmente e mantidas historicamente. Assim sendo, as condições assimétricas de poder e oportunidades - que colocam o homem em condições de superioridade à mulher (que representa $51,3 \% 82$ da população mundial) - sedimentam o recorte de gênero como um dos fatores estruturais e estruturantes das desigualdades sociais, com sérias consequências para toda a sociedade. Essa realidade é facilmente comprovada por estatísticas confiáveis, como é o caso do relatório divulgado pela Organização das Nações Unidas (ONU), intitulado As Mulheres no Mundo 2010: Tendências e Estatísticas ${ }^{83}$, com dados em oito áreas: população, família, saúde, educação, trabalho, poder e tomada de decisões, violência contra as mulheres, meio ambiente e pobreza. No documento, o Secretário-Geral da ONU, Ban Ki-moon, reconhece o progresso, mas, ressalta que "muito ainda precisa ser feito, em especial para fechar a desigualdade de gênero na vida pública e para evitar as muitas formas de violência a que são submetidas as mulheres”. Dentre os principais dados estão:

\footnotetext{
${ }^{82}$ Disponível em: <http://www.ibge.gov.br/paisesat/>. Acesso em 10 jul. 2011.

${ }^{83}$ Disponível em: <http:/www.sepm.gov.br/noticias/ultimas noticias/2010/10/onu-divulga-relatorio-sobre-asituacao-das-mulheres-no-mundo $>$. Acesso: 20 out. 2011.
} 
- [...] Chefes de Estado ou de Governo são cargos que ainda são quase que 'imperceptíveis' para as mulheres. Em 2009, apenas 14 mulheres no mundo ocupavam estas posições, este ano [2010] o número saltou para $18 \mathrm{em} 192$ países pesquisados.

- Em apenas 23 países, as mulheres compõem uma massa crítica mais de $30 \%$ - no Parlamento nacional.

- As mulheres são submetidas a diversas formas de violência: física, sexual, psicológica e econômica - tanto dentro como fora de suas casas. Taxas de mulheres vítimas de violência física pelo menos uma vez na vida variam de $12 \%$ a mais de $59 \%$, dependendo de onde vivem.

- Na virada do milênio, um número estimado de 105 milhões de meninos e meninas em idade escolar em todo o mundo não estavam matriculadas na escola. Esse número baixou para cerca de 72 milhões até 2007, representando um declínio de 31\%. As meninas representam $54 \%$ das crianças em idade escolar fora da escola (58\% em 1999). No ensino superior, o domínio dos homens foi invertido em nível global e o equilíbrio entre os sexos mudou em favor das mulheres, exceto na África Subsaariana e na Ásia Meridional e Ocidental.

- Os salários das mulheres representam entre 70 e $90 \%$ dos salários de seus colegas masculinos. 'O emprego vulnerável' trabalho por conta própria e contribuição para o trabalho familiar - é predominante na África e na Ásia, especialmente entre as mulheres. As mulheres ainda são raramente empregadas em trabalhos com status, poder e autoridade, e em ocupações tradicionalmente masculinas.

Em termos de igualdade de gênero, o Brasil está em $82^{\circ}$ lugar entre 135 países avaliados por estudo ${ }^{84}$ realizado em 2011, pelo Fórum Econômico Mundial. No ranking geral, os primeiros da lista são Islândia, Noruega, Finlândia, Suécia e Irlanda, e os últimos, Arábia Saudita, Mali, Paquistão, Chade e lêmen. 0 fato de o povo brasileiro ter escolhido uma mulher como presidente - Dilma Rousseff fez com que subisse três pontos em relação ao estudo de 2010, mas, em termos

\footnotetext{
${ }^{84} \mathrm{O}$ estudo foi coordenado pelos economistas Ricardo Hausmann (Havard) e Laura Tyson (Universidade da Califórnia em Berkley), pela pesquisadora do Fórum Econômico Mundial para Gênero, Yasmina Belhouche, e pela diretora Saadia Zahidi. Disponível em: <http://www.weforum.org/issues/global-gender-gap $>$. Acesso em: 10 nov. 2011.
} 
de América do Sul, o Brasil é o penúltimo, somente à frente do Suriname (a

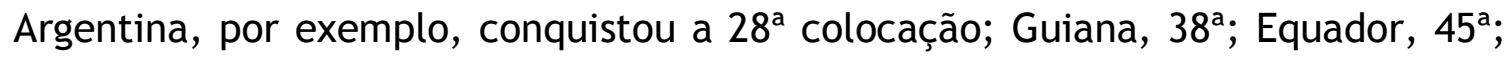

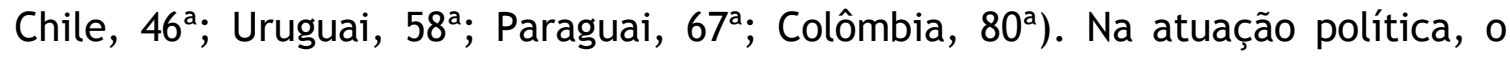
Brasil fica pior ainda, na $114^{\mathrm{a}}$ posição. 0 texto enfatiza que

[...] a participação das mulheres na força de trabalho ainda é de $64 \%$, abaixo da dos homens (85\%). E elas são só $36 \%$ dos legisladores, autoridades públicas de primeiro escalão e gerentes. 0 que elas ganham ainda está abaixo de dois terços da renda dos homens; e no Congresso, são apenas $9 \%$.

De qualquer forma, o relatório destaca em sua introdução que nos últimos seis anos, $85 \%$ dos países pesquisados demonstram melhoria nos índices de equidade de gênero. Ressalta, porém, que o restante dos países apresenta declínio, notadamente os países da África e da América do Sul: "Um pequeno declínio com relação ao ano passado foi mostrado pela Nova Zelândia, África do Sul, Espanha e Sri Lanka nos rankings de equidade de gênero, enquanto ganhos são realizados por Brasil, Etiópia, Dacar, Tanzânia e Turquia.”

Estudo recente do Instituto Brasileiro de Geografia e Estatística (IBGE) divulgado em 16/11/2011, intitulado Censo $2010^{85}$, apesar de revelar melhorias das condições de vida da população de forma geral na última década, ressalta a permanência das desigualdades que incidem sobre fatores da tríade classe, raça e gênero. Dentre as principais conclusões do censo estão a de que $1 \%$ da população mais rica concentra renda igual a dos $40 \%$ mais pobres; brancos e amarelos ganham o dobro que pretos, pardos e indígenas; a renda das mulheres representa $70 \%$ da dos homens.

\subsubsection{Dois movimentos sociais por um mesmo fim}

Apesar de o movimento feminista ser caracterizado pela presença majoritária de mulheres da classe média - como força ideológica e política que

\footnotetext{
${ }^{85}$ Disponível em $<$ http://www.censo2010.ibge.gov.br/>. Acesso: 17 nov 2011
} 
radicaliza a noção de libertação das mulheres - e o movimento de mulheres muito mais por aquelas das classes menos favorecidas economicamente preocupadas com a provisão de necessidades básicas ou por direitos de cidadania -, ambos têm como compromisso comum a luta contra a opressão masculina. Há discordâncias em determinadas bandeiras - como, por exemplo, a mais controversa que diz respeito à descriminalização do aborto, já que, nos grupos das classes sociais C, D e E, principalmente, há forte influência dos dogmas religiosos. De acordo com Maxine Molyneus (1996, p.493) ${ }^{86}$,

[...] os movimentos de mulheres antecedem o feminismo e podem ser diferentes dele. São movimentos sociais que exibem heterogeneidade de objetivos e formas de associação ou de organização. Os movimentos de mulheres têm surgido em todas as regiões do mundo e são mencionados na maior parte da história documentada. O Corão refere-se a um levante de mulheres no Sul da Arábia, as quais, segundo os estudiosos, estavam protestando contra a proibição, por Maomé, de que as mulheres exercessem o comércio. A história da América Latina e da Africana coloniais contém exemplos de escravas e camponesas rebelando-se contra as leis ou práticas do estado imperial, ou mobilizando-se para defender seus interesses econômicos. Na Europa do século XVIII mulheres formaram suas próprias associações, algumas das quais participaram da Revolução Francesa. [...] Foi no século XIX que as mulheres de muitas regiões do mundo começaram a se organizar contra as desigualdades baseadas no sexo e a exigir reformas jurídicas visando remover os controles patriarcais na família e na sociedade em geral. [...] As idéias de emancipação das mulheres eram particularmente atraentes àqueles inspirados pelas idéias do lluminismo.

A história do movimento feminista costuma ser dividida em duas etapas. A chamada "primeira onda", que vai de 1860 a 1920, surge para tornar-se influente em termos de força ideológica e política. Há dois momentos marcantes no Ocidente. Nos dias 19 e 20/07/1948, em Seneca Falls, é realizada a primeira Convenção pelos Direitos das Mulheres da América do Norte, época em que a

\footnotetext{
${ }^{86}$ MOLYNEUX, M. Movimento de Mulheres. In. Dicionário do pensamento social do século XX. Edição de William Outhwaite \& Tom Bottomore. RJ. Jorge Zahar Editor. 1996. p.493
} 
mulher era proibida de possuir propriedade, cursar universidade, acessar cargos públicos ou votar, e que Elizabeth Cady Stanton redigiu a Declaração de Sentimentos. Eram muitos os obstáculos a transpor, pois

[...] maridos tinham poder legal sobre, e responsabilidade por, suas esposas, de modo que podiam impunemente aprisioná-las ou espancá-las. Em suma, as mulheres eram privadas de autoconfiança e auto-respeito, tornando-se totalmente dependentes dos homens.

[...] Stanton, com sua mentora e amiga Lucretia Mott e outras visionárias organizaram a primeira Convenção pelos Direitos da Mulher para abordar estas e diversas outras práticas opressivas impostas às mulheres. [...] Durante dois dias de discussão a Declaração de Sentimentos e 12 outras resoluções receberam aprovação unânime. [...] 0 sistema patriarcal da época e o atual garante que um grupo de pessoas duvide da capacidade das mulheres em relação aos homens. [...] Os Estados Unidos não reconheceram o direito de auto-governo das mulheres [direito ao voto] até 1920, 72 anos mais tarde. ${ }^{87}$

O outro momento da "primeira onda" diz respeito às lutas pelo sufrágio feminino - direito ao voto -, cuja vitória da maior mobilização se deu em 1918, na Grã-Bretanha. A 'segunda onda' tem início nos anos 1960, na efervescência dos movimentos estudantis na Europa e EUA, na luta pelos direitos civis, a partir da visão de algumas teóricas como Simone de Beauvoir. De acordo com artigo publicado no site do Centro Feminista de Estudos e Assessoria (CFêmea, 2002) ${ }^{88}$,

[...] A primeira onda feminista compreende os primeiros movimentos - tem início em fins do século XVIII, com a Revolução Francesa, perpassa o século XIX e adentra as primeiras décadas do século XX. Desde aí, foram se conformando feminismos vinculados a diferentes correntes político-ideológicas:

\footnotetext{
87 Disponível em http://www.mcphearsonreport.com/1999/12/breast-rugby-soccer-and-abortion-theoppressive-connection/ . Acesso: 17 nov 2011. [tradução minha]

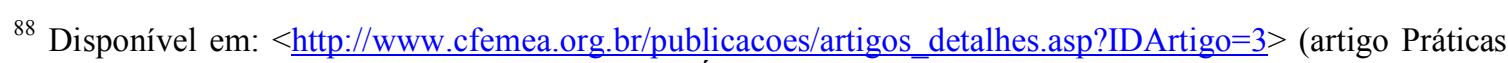
Sociais, Modelos de Sociedade e Questões Éticas: Perspectivas Feministas, de Almira Rodrigues, janeiro/2002). Acesso em: 10 set 2011.
} 
liberal, cristão, socialista, anarquista.

[...] A segunda onda feminista emerge nos anos 1960 [nos Estados Unidos] e 1960, tendo como referência o Ano Internacional da Mulher (1975) e a Década da Mulher (1976-85), ambos promovidos pela Organização das Nações Unidas - ONU. No decorrer de todo o século, foram sendo superadas as barreiras formais na maioria dos países, e as mulheres adentraram o mercado de trabalho e as universidades, incorporando-se à democracia representativa.

Para Castells (1999, p. 210-11) ${ }^{89}$, é nessa segunda onda que o feminismo apresenta

[...] características comuns que o tornam um movimento social transformador, que desafia o patriarcalismo [patriarcado] ao mesmo tempo que esclarece a diversidade das lutas femininas e seu multiculturalismo. Para expressar o conceito de feminismo, [...] usarei as palavras de Jane Mansbridge, definindo-o como 'o compromisso de pôr fim à dominação masculina'. Concordo também com a visão de Masbridge sobre o feminismo como um 'movimento criado de forma discursiva'. Isso não significa que o feminismo seja apenas discurso, ou que o debate feminista, conforme expresso nas obras de várias mulheres, teóricas e acadêmicas, seja a manifestação primordial do feminismo. 0 que asseguro, concordando com Mansbridge e outros autores, é que a essência do feminismo, como praticado e relatado, é a (re)definição da identidade da mulher [...]. Existe, portanto, uma essência comum subjacente à diversidade do feminismo: o esforço histórico, individual ou coletivo, formal ou informal, no sentido de redefinir o gênero feminino em oposição direta ao patriarcalismo [patriarcado].

As duas fotos abaixo registram momentos históricos de manifestações públicas das mulheres, em séculos diferentes, exemplificando as bandeiras de luta das ondas do feminismo. A primeira, de 1912, é mostra uma passeata reivindicando o direito ao voto. A segunda, de 2011, retrata uma forma de mobilizar pela internet a reivindicação pelo fim da violência contra a mulher: a

\footnotetext{
${ }^{89}$ CASTELLS, M. Tradução: Klaus Brandini Gerhardt. O poder da identidade. SP: Paz e Terra, 1999, $6^{\mathrm{a}}$ ed. p. $210-211$
} 
“Marcha das Vadias" começou em abril, no Canadá, e se alastrou mundo afora, depois que um policial da cidade de Toronto declarou que as mulheres "deveriam evitar se vestir como vadias para não serem agredidas".

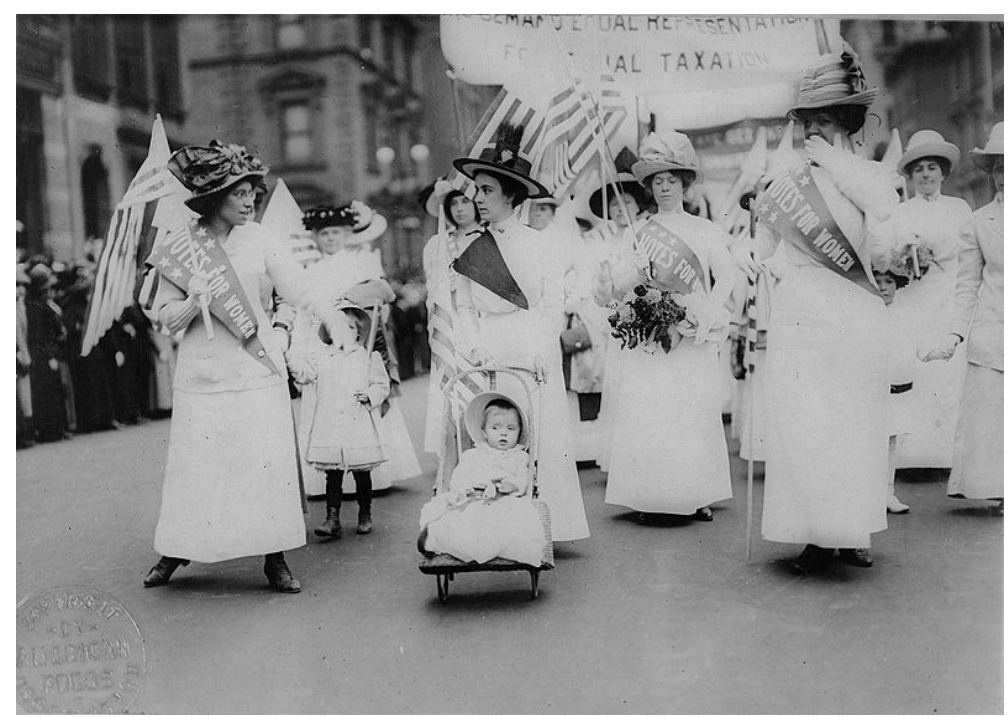

Imagem 1 - Passeata pelo voto feminino em Nova York, 1912 http://pt.wikipedia.org/wiki/Sufr\%C3\%A1gio_feminino

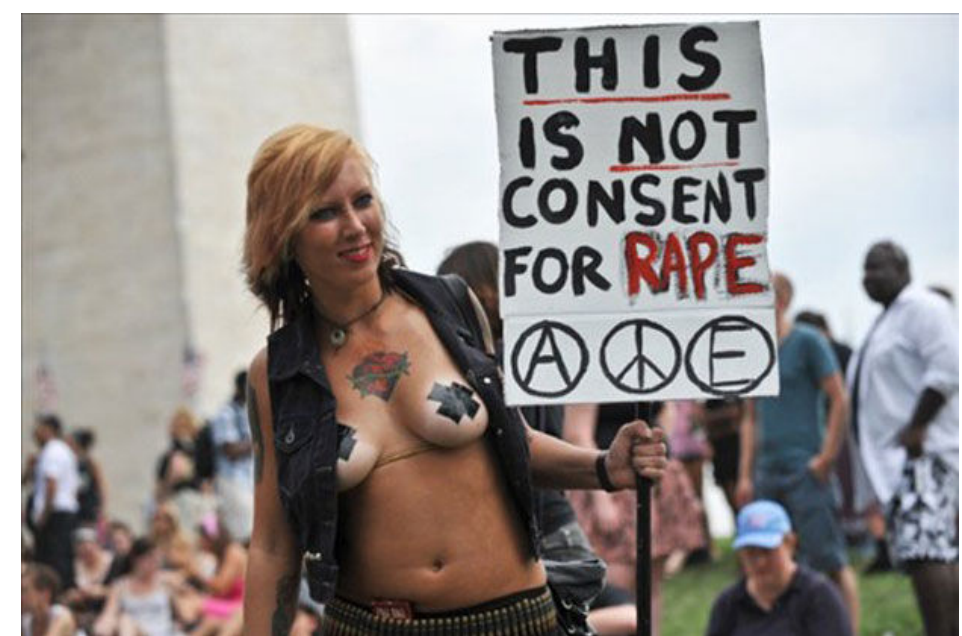

Imagem 2 - Isto não é consentimento para o estupro diz cartaz com mulher que protesta durante

'marcha das vadias' nos EUA, em 2011. (Foto: Nicholas Kamm/AFP) http://g1.globo.com/mundo/noticia/2011/08/washington-tem-marcha-das-vadiascontra-violencia-sexual.html 
Voltando à trajetória de lutas feministas, faz-se importante registrar as diferentes correntes que guiaram a produção acadêmica e as práticas. Saffioti (1987, p. 113-116 $)^{90}$ enumera as diversas correntes de pensamento feminista: Conservantismo - naturaliza processos sociais, portanto, colocando a mulher em posição naturalmente inferior ao homem; Liberalismo - restrita à visão de que "a inferioridade social da mulher deriva da desigualdade de oportunidades entre homens e mulheres, especialmente nos campos da educação e do trabalho"; Marxismo Dogmático - "não apenas privilegia a luta de classes em detrimento de outras (contra o sexismo e o racismo), como também só reconhece essa luta como legítima; Radical - "a única diferença entre o feminismo radical e o machismo consiste no fato de que o primeiro privilegia a mulher e o segundo privilegia o homem"; e, por fim, aquele que elucida neste trabalho o posicionamento desta pesquisadora, que opta por esta última corrente:

\begin{abstract}
Feminismo socialista: corrente de pensamento muito mais complexa que as anteriores, tratando de lidar, simultaneamente, com todas as contradições básicas da sociedade regida pelo patriarcado-racismo-capitalismo. [...] a estratégia aqui proposta é a do ataque à própria simbiose entre o patriarcado, o racismo e o capitalismo [grifo meu]. Esta proposta tem maior alcance do que a de atacar simultaneamente todas as contradições, todos os antagonismos. Isto significa investir contra a própria fusão dos mencionados esquemas de dominação-exploração. Se cada um deles representa uma grande força, sua simbiose não soma a força que cada um traz, mas potencia esta força. [...] Rigorosamente, o único feminismo radical do ponto de vista político é o feminismo socialista, pois ser radical significa tomar as coisas pela raiz.
\end{abstract}

A intensa mobilização das mulheres de todo o mundo, principalmente nas últimas quatro décadas, levou a conquistas importantes. Houve uma combinação crescente e fundamental entre o trabalho junto aos grupos populares, junto às esferas de poder visando interferir na criação ou implementação de leis e

${ }^{90}$ SAFFIOTI, H. O poder do macho. SP: Editora Moderna. 1987. p.113-116 
políticas públicas, bem como participando efetivamente das Conferências Internacionais da Organização das Nações Unidas (ONU) e no posterior monitoramento dos compromissos nelas assumidos pelos governos. Foi por pressão delas que a ONU decretou o Ano Internacional da Mulher, em 1975, e a Década da Mulher em todo o mundo, até 1985. Foram quatro grandes conferências da ONU específicas sobre a situação da mulher, desde 1975:

1975 - México - I Conferência Mundial sobre as Mulheres, com o tema 'Igualdade, Desenvolvimento e Paz', em que se baseariam as ações do decênio seguinte.

1980 - Copenhague - Conferência destinada a conhecer a realidade e propor alternativas de enfrentamento dos problemas das mulhe-res em relação à educação, ao emprego e à saúde.

1985 - Nairobi - O foco da III Conferência foi avaliar as conquistas da Década da Mulher (1976-1985)

1995 - Beijing - A finalidade primordial da IV Conferência sobre a Mulher foi renovar o interesse internacional pela causa das mulheres, articulando-a com a questão do desenvolvimento e dos direitos humanos. (CARRERA ET AL, 2001) ${ }^{91}$

$O$ percurso feminista latinoamericano a partir de meados do século $X X$, registrado em uma publicação da Repem $(1990)^{92}$, aponta as seguintes principais fases: dos anos 1950 - luta por reformas de base, ao final dos 1960 - luta pela redemocratização -, em que as mulheres estavam inseridas nos movimentos sociais. Em seguida, elas buscam a autonomia do movimento feminista para responder aos reais interesses das mulheres, passando a desenvolver uma metodologia sob a perspectiva das relações sociais de gênero, frisando que o cotidiano é político. Formam mulheres para o exercício de lideranças que fomentem a organização popular feminina ou que se insiram nas diversas instâncias de poder, conscientes de que o tema da liderança está intimamente

\footnotetext{
${ }^{91}$ CARREIRA, D.; AJAMIL, M.; MOREIRA. T. (org). A liderança feminina no século 21. SP: Co-edição: Cortez e Rede Mulher. 2001. p. 202.

92 REPEM. Educação popular e liderança das mulheres na construção da democracia latino-americana. Quito/Equador. set/90.
} 
ligado à construção da democracia, à participação nos diversos âmbitos da vida social. Nos anos 1990, lançam um olhar crítico ao caminho já percorrido e incidem na necessidade de influenciar nas políticas públicas. No final dessa década, concluem, também, que a mulher não está avançando na ocupação de cargos de poder, passando a refletir sobre a busca da liderança transformadora, levantando a necessidade de condições materiais e de formação para lidar com os conflitos - privados e públicos -, no exercício da liderança. Ao conquistar o "direito" de ocupar o espaço público, as mulheres passaram a acumular a tripla jornada, ou seja, a da esfera produtiva (feita em troca de pagamento), a da esfera reprodutiva e da gestão comunitária (na luta por serviços básicos, de saúde, educação, habitação, etc.).

Marca-se, aí, um impasse para o avanço da luta das mulheres. Mas, o que não se assinala nessas reflexões é o poder da mídia - fortalecido pelo avanço das inovações tecnológicas -, que pode perpetuar as desigualdades de gênero, mas que também pode se tornar um estratégico campo de intervenção para auxiliar no avanço da luta das mulheres, em qualquer dos dois movimentos.

\subsection{A violência contra a mulher como consequência do binômio dominação / subordinação}

É possível transmitir - de forma criativa e assimilável para grande parte da sociedade - a complexidade de um tema como a construção cultural de gênero, que gera o machismo, e a consequência mais cruel para a sociedade que é a violência contra a mulher. É o que comprova a autora do cordel "O caso Eliza Samudio e o machismo total" "93, de Salete Maria, doutoranda do Programa de PósGraduação do Núcleo de Estudos Interdisciplinares sobre a Mulher da Universidade Federal da Bahia (PPGNEIM/ UFBA). Apesar de oferecer subsídios

\footnotetext{
${ }^{93}$ Disponível em $<$ http://cordelirando.blogspot.com/2010/07/0-caso-eliza-samudio-e-o-machismo-total.html $>$ Acesso em 10 Jul 2011.
} 
para uma reflexão mais aprofundada sobre a importância do movimento feminista e da academia deixarem de "falar para o gueto", o que interessa neste tópico é se debruçar sobre conceitos fundamentais para explicar as razões pelas quais persiste a realidade das estatísticas dos altos índices de violência contra a mulher, que não escolhe classe social, nível educacional, raça, etnia, religião, países pobres ou ricos. Para Giddens (1993, p.136-138) ${ }^{94}$

[...] A força e a violência fazem parte de todos os tipos de dominação. [...] Também sugere-se que a violência contra as mulheres, especialmente o estupro, é o principal esteio do controle dos homens sobre elas. 0 estupro mostra a realidade da regra do falo. Parece claro que há uma continuidade, não uma interrupção nítida, entre a violência masculina em relação às mulheres e outras formas de intimidação e perseguição. [...] Nas sociedades modernas [...] as mulheres vivem e trabalham em ambientes públicos anônimos com muito mais frequência do que antes, e as divisões 'isoladas e desiguais' que separavam os sexos foram substancialmente desfeitas. Faz mais sentido hoje em dia do que no passado a suposição de que a violência sexual masculina tornou-se a base do controle sexual. Em outras palavras, atualmente, grande parte da violência sexual masculina provém mais da insegurança e dos desajustamentos, do que de uma continuação ininterrupta do domínio patriarcal. A violência é uma reação destrutiva ao declínio da cumplicidade feminina. [...] Exceto em situações de guerra, hoje em dia os homens talvez sejam mais violentos com relação às mulheres do que o são entre si.

A violência contra a mulher é, no mundo todo, a mais trágica expressão da construção social de gênero que coloca o homem em posição de superioridade à mulher, desencadeando relações desiguais de poder e oportunidades, com malefícios a toda a sociedade. A forma como se vem aprendendo a ser homem e a ser mulher não é boa para nenhuma das partes, e um processo de desconstrução tangível requer esforços conjuntos. Ao definir os meandros da

\footnotetext{
${ }^{94}$ GIDDENS, A. A transformação da intimidade. Tradução: Magda Lopes. São Paulo: Ed. UNESP, 1993. p. 136-138.
} 
violência contra a mulher, Teles e Melo (2002, p.15) ${ }^{95}$, explicam que

[...] em seu significado mais freqüente, quer dizer uso da força física, psicológica ou intelectual para obrigar outra pessoa a fazer algo que não está com vontade; é constranger, é tolher a liberdade, é incomodar, é impedir a outra pessoa de manifestar seu desejo e sua vontade, sob pena de viver gravemente ameaçada ou até mesmo ser espancada, lesionada ou morta. É um meio de coagir, de submeter outrem ao seu domínio, é uma violação dos direitos essenciais do ser humano.

De acordo com pesquisa da Fundação Perseu Abramo96, de 2001 (a mais completa sobre o tema), intitulada Violência contra a Mulher, no Brasil, a cada 15 segundos uma mulher é espancada. E 70\% das agressões ocorrem dentro de casa, praticadas pelo marido, companheiro ou parente. No estado de Pernambuco, somente em 2006 foram assassinadas quase 300 mulheres ${ }^{97}$. Segundo dados do Banco Mundial e do Banco Interamericano de Desenvolvimento, divulgados no portal www.agenciapatricia galvao.org.br, um em cada cinco dias de falta ao trabalho no mundo é causado pela violência sofrida pelas mulheres dentro de suas casas. A cada cinco anos, a mulher perde um ano de vida saudável se ela sofre violência doméstica. De acordo com o Mapa da Violência no Brasil/ 201098, no período de 1997 a 2007, 41.532 mulheres foram assassinadas no país, ou seja, um índice de 4,2 vítimas por grupo de 100 mil habitantes. Segundo artigo de Frei Beto ${ }^{99}$,

[...] o Núcleo de Violência da Universidade de São Paulo identifica como assassinos maridos, ex-maridos e namorados inconformados com o fim da relação. Ao forte componente de misoginia (aversão à mulher), acresce-se a prepotência machista

\footnotetext{
95 TELES, M.A.A.; MELO, M. O que é violência contra a mulher. São Paulo: Ed.Brasiliense, 2002. p. 15.

96 Disponível em: <http://200.130.7.5/spmu/docs/pesq Violencia\%20contra\%20a\%20mulher.pdf $>$. Acesso em 30 set. 2011.

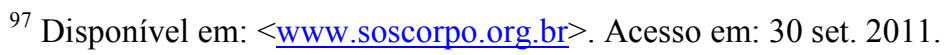

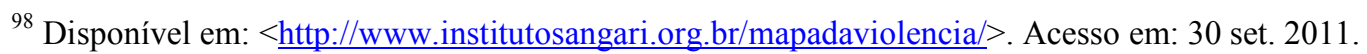

${ }^{99}$ Disponível em: <http://www.ciranda.net>. Acesso em: 30 set. 2011.
} 
de quem se julga dono da parceira e, portanto, senhor absoluto sobre o destino dela.

A ONG international Vital Voices, responsável pela criação da Aliança Global pelo Fim da Violência contra Mulheres, visando soluções múltiplas e interligadas, lançada em março de 2010, em Washington - que reuniu 200 lideranças de diversas partes do mundo e contou com minha presença na representação das ONGs brasileiras - identifica três tipos mais comuns de violência contra a mulher: violência doméstica, tráfico humano e violência sexual. De acordo com a Vital Voices ${ }^{100}$, a violência doméstica é um

[...] padrão de comportamento abusivo, utilizado para estabelecer poder e controle sobre outra pessoa, com quem se tem ou se teve um relacionamento íntimo. Tal comportamento inclui violência física, violência sexual e violência emocional/ psicológica. Os agressores são, em sua maioria, homens, e as mulheres são as vítimas. A violência doméstica afeta mulheres urbanas e rurais, independente de idade, religião, raça/ etnia, nível social/ econômico e educacional. Em média, uma em cada três mulheres é agredida ou forçada a ter relações sexuais no transcorrer da vida. Mulheres adolescentes estão mais susceptíveis a sofrer estupro ou violência doméstica do que ter um acidente de moto, câncer ou malária. Pesquisas mundiais também demonstraram que $40 \%$ a $70 \%$ das mulheres vítimas de homicídios foram assassinadas por seus maridos, ex ou parceiros. A violência doméstica também causa uma grande perda econômica ao país (nos Estados Unidos, a perda de produtividade totaliza USD $1.8 \mathrm{bi}$, enquanto que os gastos com saúde chegam a USD 4.1 bi. A raiz do problema da violência contra a mulher está na construção cultural de gênero, que coloca o homem em posição de superioridade à mulher. Nenhum setor da sociedade consegue sucesso lutando sozinho contra tal tragédia. É necessária a união das ONGs, setor empresarial e governo.

A gravidade da problemática também se traduz na campanha UNA-SE pelo fim da violência contra as mulheres lançada pelo Secretário-Geral da

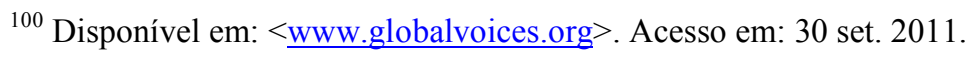


Organização das Nações Unidas (ONU), Ban Ki-moon, por ocasião das celebrações do Dia Internacional da Mulher, em 8 de março de 2010. Em seu mandato, de 2007 a 2011, ele considerou um dos maiores desafios o enfrentamento da violência contra a mulher, reconhecendo a necessidade de unir esforços de mulheres e homens, de diferentes gerações, quer no árduo trabalho de desconstrução dos estereótipos de gênero, quer no campo da implantação e implementação de legislação.

\subsection{Lei Maria da Penha}

O Brasil possui uma legislação específica sobre a violência contra a mulher que é considerada uma das mais avançadas do mundo, o que foi reconhecido recentemente em artigo (2010, p. 3) ${ }^{101}$ de Rebecca Reichmann Tavares (2010, p. 3), então representante da região Brasil e Cone Sul do Fundo de Desenvolvimento das Nações Unidas para a Mulher (Unifem), que é parte da ONU Mulheres ${ }^{102}$. Tavares salienta que "apesar das medidas judiciais estabelecidas pela Lei Maria da Penha, sua real aplicação é comprometida por um sistema que não assegura proteção". Com o foco no caso do assassinato de Eliza Samudio, o artigo foi estratégico para a reflexão sobre os problemas que ocorrem na implementação de uma legislação. Sancionada no Brasil em 7/8/2006, pelo presidente Lula, a Lei $11.340^{103}$ é uma vitória importante na trajetória de luta por uma vida sem violência. O cerne da mudança jurídica se encontra no fato de que os agressores passaram a ser presos em flagrante ou, em caso de risco físico ou psicológico às vítimas, terem a prisão preventiva decretada. Além disso, a Lei, que entrou em vigor em 22/9/2006, assegura que não haverá mais a aplicação de penas como multa ou doação de cestas básicas. A violência doméstica é tipificada como uma

\footnotetext{
${ }^{101}$ TAVARES, R. R. Basta à violência contra as mulheres. Folha de S.Paulo. SP. 16/07/10. p.3

${ }^{102}$ A ONU Mulheres - Entidade das Nações Unidas para a Igualdade de Gênero e o Empoderamento das Mulheres - é resultado de anos de negociações entre Estados-membros da ONU e movimentos de defesa das mulheres no mundo. Foi criada em 02/07/2010, entrando em funcionamento em 2011. cf. www.unifem.org.br

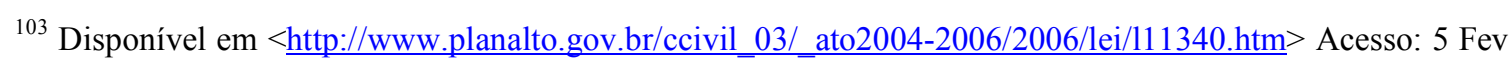
2011.
} 
das formas de violação dos direitos humanos. Os crimes passam a ser julgados em varas criminais até a instituição dos Juizados de Violência Doméstica e Familiar contra a Mulher no âmbito estadual. Com isso, as ações penais, pela violência, e civil, pela separação e filhos, entre outros, serão encaminhadas de uma só vez. Há também outras medidas de proteção para a mulher que sofre risco de vida, como o afastamento do agressor do domicílio e a proibição de sua aproximação física da mulher agredida e dos filhos. A nova Lei determina também que um advogado acompanhe a mulher em todas as fases do processo, proíbe que ela seja encarregada de entregar a intimação ao agressor e diz que a mulher só pode desistir da denúncia perante o juiz.

Para a ex-ministra Nilcéa Freire - cuja gestão também foi responsável pela implantação do serviço Ligue 180, outro instrumento primordial para as mulheres em situação de violência - essa é uma lei necessária. Em artigo (2006, p. 3) ${ }^{104}$, ela destaca que,

[...] rupturas culturais são desoladoramente lentas, requerem mudanças de atitude nos lares e sociedades, nos marcos legais e institucionais. Somando-se às questões de natureza cultural - e também como sua consequência -, a inexistência de uma legislação específica vinha garantindo a impunidade dos agressores. Situações que começaram como uma ameaça, evoluíram muitas vezes para assassinatos sem que qualquer intervenção pudesse ser ou fosse feita para evitá-lo.

São cinco os tipos de violência doméstica estipulados pela Lei Maria da Penha:

- Violência física: qualquer ato contra a integridade ou saúde corporal da vítima.

- Violência psicológica: qualquer ação que cause prejuízo psicológico, como humilhação, chantagem, insulto, isolamento, ridicularização, dano emocional e controle do comportamento da mulher.

${ }^{104}$ FREIRE, N. Onde tem violência, todo mundo perde. Folha de S. Paulo. SP. 06/08/2006. p.3. 
- Violência sexual: aquela que força a mulher a presenciar, manter ou participar de relação sexual; impedir o uso de método contraceptivo ou forçá-la à gravidez, aborto ou prostituição mediante força ou ameaça.

- Violência patrimonial: situações em que o agressor destrói bens, documentos pessoais e instrumentos de trabalho.

- Violência moral: caluniar, difamar ou cometer injúria contra a mulher.

A brasileira Sílvia Pimentel, atual presidenta do Comitê sobre a Eliminação da Discriminação contra as Mulheres (Cedaw ${ }^{105}$, sigla em inglês), da ONU, é doutora em filosofia, professora universitária e militante histórica do movimento de mulheres e feminista, principalmente no que tange à violência e à descriminalização do aborto. Em artigo (2011, p. 3) ${ }^{106}$ redigido junto com a acadêmica Flávia Piovesan, por ocasião da posse da primeira presidenta brasileira, Dilma Rousseff, ela destacou a urgência de transformação dos lugares designados para cada sexo no espaço privado e no espaço público, visando ao enfrentamento das conseqüências do desequilíbrio das relações sociais de gênero:

[...] Ao longo da história, atribuiu-se às mulheres a esfera privada - os cuidados com o marido, com os filhos e com os afazeres domésticos -, enquanto aos homens foi confiada a esfera pública. Nas últimas três décadas, no entanto, houve a crescente democratização do domínio público, com a significativa participação de mulheres, ainda remanescendo o desafio de democratizar o domínio privado - o que não só permitiria o maior envolvimento de homens na vivência familiar, com um grande ganho aos filhos(as), mas também possibilitaria a maior

\footnotetext{
${ }^{105}$ A Convenção sobre a Eliminação de Todas as Formas de Discriminação contra a Mulher (Cedaw) é a lei internacional dos direitos das mulheres. Ela baseia-se no compromisso dos Estados signatários de promover e assegurar a igualdade entre homens e mulheres e de eliminar todos os tipos de discriminação contra a mulher. A CEDAW foi aprovada pela Organização das Nações Unidas em 1979, tendo entrado em vigor em 1981. Atualmente, 173 países - mais de dois terços dos membros da ONU - ratificaram a Convenção: Uruguai, em 1981; Brasil e Chile em 1984; Argentina, em 1985; Paraguai, 1987. Disponível em <http://www.unifem.org.br/ 005/00502001.asp?ttCD_CHAVE=8466>. Acesso: 20 nov 2011.

${ }^{106}$ PIOVESAN, F.; PIMENTEL, S. Mulher, Democracia e Desenvolvimento. São Paulo: Folha de S.Paulo. Tendências. 9/1/2011. p. A3.
} 
participação política de mulheres. [...] Os países que apresentam a menor desigualdade de gênero são justamente os mesmos que ostentam o maior índice de desenvolvimento humano.

Ao final da $11^{\text {a }}$ Conferência Regional sobre a Mulher da América Latina e Caribe, realizada em Brasília, de 13 a 16/07/10, promovida pela Comissão Econômica para a América Latina e o Caribe (Cepal) ${ }^{107}$, para discutir o tema dos desafios e conquistas para alcançar a igualdade de gênero com ênfase na autonomia e no empoderamento econômico das mulheres, foi divulgado o documento intitulado Consenso de Brasília ${ }^{108}$, o qual destaca, inicialmente, a campanha da ONU - UNA-SE pelo fim da violência contra as mulheres - e dedica um dos blocos de acordos para a ação dos governos envolvidos, relacionado à violência contra as mulheres. Dentre os principais itens da parte intitulada "Enfrentar todas as formas de violências contra as mulheres", destacam-se abaixo aqueles relacionados principalmente à violência doméstica, objeto desta tese:

a) Adotar medidas preventivas, punitivas, de proteção e atenção que contribuam à erradicação de todas as formas de violência contra as mulheres nos espaços públicos e privados;

b) Ampliar e garantir o acesso efetivo à justiça e à assistência jurídica gratuita das mulheres em situação de violência e capacitar e sensibilizar, desde um enfoque do gênero, o pessoal e os funcionários encarregados do processo judicial;

f) Incorporar nas políticas de segurança pública medidas específicas para prevenir, investigar, sancionar e erradicar o femicídio e o feminicídio ${ }^{109}$, entendidos como a forma mais extrema de violência de gênero contra as mulheres;

\footnotetext{
${ }^{107}$ A Cepal foi criada em 1948 pelo Conselho Econômico e Social das Nações Unidas com o objetivo de incentivar a cooperação econômica entre os seus membros. Ela é uma das cinco comissões econômicas da ONU e possui 44 estados e oito territórios independentes como membros. Além dos países da América Latina e Caribe, fazem parte o Canadá, França, Japão, Países Baixos, Portugal, Espanha, Reino Unido, Itália e EUA. (disponível em: $<$ http://pt.wikipedia.org/wiki/Cepal>. Acesso em: 30 set. 2011).

${ }^{108}$ Disponível em: <www.cepal.org/mujer/conferencia/doc/ConsensoBrasilia > . Acesso em: 30 set. 2011.

${ }^{109}$ Trata-se de uma categoria criada para englobar o que há em comum na agressão e morte de mulheres pelo
} 
g) Promover políticas e programas dirigidos aos agressores e suas famílias para prevenir a reincidência;

i) Criar sistemas nacionais de vigilância da violência de gênero para recopilar, compilar e analisar dados sobre a violência de gênero com vistas a influir nas políticas e programas nacionais e locais;

k) Promover e fortalecer programas de sensibilização e capacitação com perspectiva de gênero, dirigidos a operadores de justiça que assegurem um atendimento de qualidade e eliminem a violência institucional contra as mulheres;

m) Garantir o atendimento integral, multiprofissional gratuito para as mulheres vítimas de violência;

n) Promover e adotar medidas para a alocação orçamentária para os programas de prevenção e atendimento da violência contra as mulheres.

Sem dúvida, é da maior importância o compromisso assumido pelos governos para a implantação e implementação de políticas públicas para o enfrentamento da violência contra a mulher, o que deve ser monitorado pela sociedade civil organizada visando seu cumprimento. Entretanto, como dito no início deste tópico, a questão é de tamanha complexidade que exige o entrelaçamento das ações dos diversos segmentos. Daí a escolha deste foco nesta pesquisa de doutorado, dentro do tema geral da comunicação e do feminismo, com o intuito de contribuir com as possibilidades de avanço oferecidas pela era digital.

\subsection{As raízes da violência contra a mulher}

Visando ao aprofundamento das causas da violência contra a mulher para

fato de serem mulheres, evidenciando o impacto político de uma desigualdade de gênero. No México, como em outros países da América Latina, foi abeto o debate acerca da necessidade de tipificar o feminicídio como um delito autônomo, porque tem características e especificidades que o diferenciam de outro tipo de homicídios. Disponível 
melhor ancorar a trajetória desta pesquisa, foram buscadas as contribuições do pensamento feminista desenvolvido por autoras de renome como Heleieth Saffioti e Laura Segato. Esta última, antropóloga e professora doutora da Universidade de Brasília (UnB), traz uma reflexão importante ao identificar a origem e a reprodução da violência na intersecção entre dois eixos perpendiculares, o vertical e o horizontal, no livro Las estruturas elementales de la violência: ensayos sobre gênero entre la antropologia, el psicoanálisis y los derechos humanos. Tal contribuição consta do artigo intitulado As raízes da violência na sociedade patriarcal (2003, p. 237) $)^{110}$ enfatizando que há,

[...] por um lado, o eixo vertical que traz em si a relação do dominador com o dominado, do agressor com sua vítima, e, por outro, o horizontal que denuncia o dominador com seus pares seus semelhantes, aliados e sócios do mesmo nível hierárquico. A condição de iguais que faz possível as relações de competição e aliança entre estes últimos resulta justamente de sua demonstrada capacidade de dominação sobre aqueles desiguais que ocupam a posição inferior. Em todos os âmbitos, a geometria da violência é a mesma e caminha sobre esses dois eixos, uma vez que para ser um 'igual' é necessário manter dependentes ou subordinados no eixo vertical - fato que se estende da esfera doméstica aos espaços públicos mais amplos. Somados a isso, a força e o poder dos 'iguais' são medidos em termos de sua capacidade de manter um contingente de 'desiguais' sob controle e rotineiras formas de sujeição, o que obriga tal sistema a se reproduzir com intervenções bélicas cíclicas e leva à violação, enquanto um ato forçado e naturalizado de um tributo sexual a desempenhar um papel fundamental na reprodução da economia simbólica do poder, uma vez que o feminino é posto no lugar de doador de atributos que tornarão o violador um igual.

Saffioti elabora uma contribuição fundamental às teorias feministas, especificamente sobre a questão do patriarcado, cuja consequência para as relações na sociedade também foi abordada de maneira simples no cordel de

\footnotetext{
${ }^{110}$ ALMEIDA. T. M. C. A. As raízes da violência na sociedade patriarcal. Sociedade e Estado. Vol.19. no 1. Brasília. Jan/Jun/2004. (também disponível em www.scielo.br)
} 
Salete Maria, O caso Eliza Samudio e o machismo total, no trecho que diz: "Homens que matam mulheres/ Em relações de poder/ Isto tem se dado em série/ Mas é preciso entender/ Que subjaz ao evento/ Um histórico comportamento/ Que vai construindo o ser” (2010). Daí o entrelaçamento contido no título do livro Gênero, Patriarcado, Violência, e o entendimento do termo patriarcado para além do pensamento patriarcal, isto é, sob a luz do feminismo. Para Saffioti (2004, p. 56-58) ${ }^{111}$,

[...] à medida que as(os) teóricas(os) feministas forem se desvencilhando das categorias patriarcais, não apenas adquirirão poder para nomear de patriarcado o regime atual de relações homem-mulher, como também abandonarão a acepção de poder paterno do direito patriarcal e o entenderão como direito sexual. Isto equivale a dizer que o agente social marido se constitui antes que a figura do pai. Esta se encontra atenuada nas sociedades complexas contemporâneas, mas ainda é legítimo afirmar-se que se vive sob a lei do pai. Todavia, a figura forte é a do marido, pois é ela que o contrato sexual dá à luz. 0 pátria potestas cedeu espaço, não à mulher, mas aos filhos. 0 patriarca que nele estava embutido continua vivo como titular do direito sexual. [...] Por que se manter o nome patriarcado? 1- não se trata de uma relação privada, mas civil; 2- dá direitos sexuais aos homens sobre as mulheres, praticamente sem restrição; [...] 3- configura um tipo hierárquico de relação, que invade todos os espaços da sociedade; 4- tem uma base material; 5- corporifica-se; 6representa uma estrutura de poder baseada tanto na ideologia quanto na violência.

Para enfocar a questão da violência contra a mulher é necessário ir às raízes do patriarcado, materializado na opressão masculina cotidiana. Para tanto, há que se debruçar sobre dois conceitos básicos: poder e ideologia. Durante a arguição de Heleieth Saffioti pela Banca de Qualificação ${ }^{112}$ desta

\footnotetext{
${ }^{111}$ SAFFIOTI, Heleieth. Gênero, Patriarcado, Violência. Editora Fundação Perseu Abramo. SP: 2004. p.56 a 58.

112 A doutoranda foi aprovada no Exame de Qualificação em 22/09/2010. Participaram da Banca: a orientadora Maria Cristina Castilho Costa, Adilson Odair Citelli e Heleieth Saffioti, os quais ofereceram excelentes contribuições que estão retratadas neste trabalho final, tanto em termos de forma como de
} 
doutoranda, ela destacou que "uma ideologia não se sustenta sem uma estrutura de poder receptiva e também produtora das condutas de homens e mulheres, portanto, não se mexe na ideologia sem se mexer na estrutura de poder”. De forma didática, citou como exemplo o fato de se encontrar, em uma fábrica, máquinas com medidas apropriadas para o corpo masculino, sendo que a maioria delas é operada por mulheres. "É a materialização da ideologia do machismo", frisa ela, que em seu livro (2004, p. 124) ${ }^{113}$, elabora melhor essa teoria:

[...] A ideologia sexista corporifica-se nos agentes sociais tanto de um polo quanto de outro da relação de dominação-subordinação. O sentido figurado da corporificação das ideologias em geral e da sexista em especial reside no vínculo arbitrariamente estabelecido entre fenômenos: voz grave significa poder, ainda que a pessoa fale baixo. 0 porquê disto encontra-se na posição social dos homens como categoria social em relação à das mulheres. A voz grave do assalariado não o empodera diante de seu patrão, pois o código da estrutura de classe é outro.

Logo a seguir, a autora (2004, p. 124) $)^{114}$ destaca o vínculo entre sexismo e racismo, considerando-os “irmãos gêmeos":

[...] $\mathrm{Na}$ gênese do escravismo constava um tratamento distinto dispensado a homens e a mulheres. Eis por que o racismo, base do escravismo, independentemente das características físicas ou culturais do povo conquistado, nasceu no mesmo momento histórico em que nasceu o sexismo. Quando um povo conquistava o outro, submetia-o a seus desejos e as suas necessidades. Os homens eram temidos, em virtude de representarem grande risco de revolta, já que dispõem, em média, de mais força física que as mulheres, sendo, ainda, treinados para enfrentar perigos. Assim, eram sumariamente eliminados, assassinados. As mulheres eram preservadas, pois serviam a três propósitos: constituíam força de trabalho, importante fator de produção em sociedades sem tecnologia ou possuidoras de tecnologias rudimentares; eram

\footnotetext{
conteúdo. Infelizmente, em 14/12/2010, Heleieth morreu.

${ }^{113}$ Ibidem. p. 124.

${ }^{114}$ Ibidem. p. 124
} 
reprodutoras desta força de trabalho, assegurando a continuidade da produção e da própria sociedade; prestavam (vendiam) serviços sexuais aos homens do povo vitorioso. Aí estão as raízes do sexismo, ou seja, tão velho quanto o racismo.

Ao se debruçar na esfera ideológica, esta pesquisadora é remetida às aulas da disciplina intitulada "Cotidiano e Linguagem", ministrada pela professora Maria de Lourdes Motter ${ }^{115}$, no primeiro semestre de 1998, no Curso de Gestão da Comunicação, da USP/ECA. O signo é uma unidade dotada de sentido e que tem um papel fundamental na linguagem. O signo é a junção do significado (conceito) e do significante (imagem). É a palavra e o símbolo, sendo ambos indissociáveis. A existência do signo nada mais é do que a materialização da comunicação, e é nisso que consiste a natureza de todos os signos ideológicos. Para Bakhtin (1999, p. 33$)^{116}$,

[...] No domínio dos signos, isto é, na esfera ideológica, existem diferenças profundas, pois este domínio é, ao mesmo tempo, o da representação, do símbolo religioso, da fórmula científica e da forma jurídica, etc. Cada campo de criatividade ideológica tem seu próprio modo de orientação para a realidade e refrata a realidade à sua própria maneira. Cada campo dispõe de sua própria função no conjunto da vida social. É seu caráter semiótico que coloca todos os fenômenos ideológicos sob a mesma definição geral.

Cada signo ideológico é não apenas um reflexo, uma sombra da realidade, mas também um fragmento material dessa realidade. Todo fenômeno que funciona como signo ideológico tem uma encarnação material, seja como som, como massa física, como cor, como movimento do corpo ou como outra coisa qualquer. Nesse sentido, a realidade do signo é totalmente objetiva e, portanto, passível de um estudo metodologicamente unitário e objetivo. Um signo é um fenômeno do mundo exterior. 0 próprio signo e todos os seus efeitos (todas as ações, reações e novos

\footnotetext{
${ }^{115}$ Infelizmente, a Lourdinha (como era carinhosamente conhecida), morreu em 10/05/2007.

${ }^{116}$ BAKHTIN, M. Marxismo e filosofia da linguagem. Tradução: Michel Lahud e Yara Frateschi Oliveira. SP: Editora Hucitec. 1999. p. 33
} 
signos que ele gera no meio social circundante) aparecem na experiência exterior.

As concepções de Bakhtin não somente ampliam o entendimento acerca do conceito de ideologia, como propiciam uma introdução a um dos focos do próximo capítulo deste trabalho relacionado aos papéis de representação da mulher nas mídias tradicionais e as possibilidades de mudanças com as novas dinâmicas comunicacionais em função das mídias digitais. 
5

A constituição do imaginário e a representação da mulher na mídia 
A fórmula estereotipada adapta-se, em qualquer lugar, ao canal de interação social que the é reservado, refletindo ideologicamente o tipo, a estrutura, os objetivos e a composição social do grupo.

Mikhail Bakhtin 


\subsection{O imaginário na construção do pensamento e de práticas cotidianas}

Sem contradizer o capítulo inicial desta pesquisa, no sentido de que os meios de comunicação de massa sempre foram instrumentos valiosos na trajetória de luta pela cidadania das mulheres, faz-se necessário o aprofundamento teórico de termos relacionados à constituição do imaginário, visando, principalmente, relativizar o poder de construção de símbolos negativos nesse percurso. Imagem, imaginário, simbologia, representação... Palavras que inquietam mais do que nunca numa época de plena revolução das tecnologias da informação e comunicação. Mas, que peso teria na construção da realidade algo que foge completamente ao consagrado esquema binário "certo ou errado", "verdade ou mentira" e do prolóquio aristotélico "saber pela causa"? A multiplicidade de significados se perde na procura do significante: subjetividade, ficção, não palpável, imponderável, mistério da criação, estado de espírito de um povo, aura, atmosfera, onírico, lúdico, fantasia, sonho, afeto, sensibilidade, sentimento, interatividade, vibração, sensação, romântico, telúrico, místico, não racional, cósmico, fantástica transcendental... Mais parece "a louca da casa a que a sumaríssima psicologia clássica o reduz [...]" (DURAND, 2001, p. 19) ${ }^{117}$; ao invés de ser entendido como

[...] os processos de produção, transmissão e recepção - o museu [...] da imagem mental (a imagem perceptiva, das lembranças, das ilusões, etc.) ou icônica (o figurativo pintado, desenhado, esculpido e fotografado...); [...] uma representação incontornável, a faculdade de simbolização de onde todos os medos, todas as esperanças e seus frutos culturais jorram continuamente desde os cerca de um milhão e meio de anos que o homo-erectus ficou em pé na face da Terra (2001 [2], p. 5-6) ${ }^{118}$. [...] 0 imaginário - ou seja, o conjunto das imagens e relações de imagens que constituiu o capital pensado do homo-sapiens -

\footnotetext{
117 DURAND, G. As estruturas antropológicas do imaginário. Tradução: Hélder Godinho. SP: Martins Fontes. $2^{\text {ed }}$ 2001. p. 19

${ }^{118}$ Idem. O imaginário - ensaio acerca das ciências e da filosofia da imagem. Tradução: René Eve Levié. RJ: Difel. $2^{\text {a }}$ ed. 2001 . p.5-6 e 117
} 
aparece-nos como o grande denominador fundamental onde se vêm encontrar todas as criações do pensamento humano. (2001 [1], p.19) ${ }^{119}$

Numa revisão mais incisiva sobre o pensamento ocidental, segundo Maffesoli (2001, p. 75) ${ }^{120}$, alguns pensadores consagrados vêm se dedicando ao tema:

[...] Bachelard pegou o bastão dos românticos e repôs na cena intelectual procedimentos que se encontravam esquecidos. Assim, mostrou que as construções mentais podiam ser eficazes em relação ao concreto. Na esteira de Bachelard, surge Gilbert Durand. Bachelard teve dois discípulos diretos - François Dagonnier e Durand. Cada um explorou um caminho. Durand trabalhou na confluência da tradição literária romântica e da antropologia, tendo escrito uma obra-prima - As estruturas antropológicas do imaginário. A sua reflexão recuperou o que tinha sido deixado de lado pela modernidade e indicou como o real é acionado pela eficácia do imaginário, das construções do espírito.

Uma construção internalizada por milênios como a da relação de dominação dos homens sobre as mulheres requer um processo cotidiano de desconstrução. No período em que esta pesquisadora viveu no Canadá, foi possível constatar esse desafio sendo retratado em uma série de reportagens, publicadas no início dos anos 90, no jornal The Toronto Star. Por que persistia o elevado número de casos de violência contra a mulher, atingindo qualquer faixa etária, nível educacional, classe social, raça ou etnia, em um país em que, ao acionar o telefone de emergência 911, ela tem à sua porta, em apenas três minutos, um carro de polícia, um de bombeiro e uma ambulância? Além disso, passava a contar com proteção legal, médico-hospitalar, psicológica, habitacional, educacional e ajuda financeira para si e seus/suas filhos/as. Quais

\footnotetext{
119 DURAND, G. As estruturas antropológicas do imaginário. Tradução: Hélder Godinho. SP: Martins Fontes. $2^{\text {a }}$ ed. 2001. p.18

${ }^{120}$ MAFFESOLI, M. O imaginário é uma realidade. Entrevista à Revista Famecos. Porto Alegre. no.15. agosto/2001. p.75
} 
ações seriam necessárias para conter o elevado número de mulheres que, depois de alguns dias, retiravam a queixa policial e voltavam para seus maridos, muitas vezes para serem, depois de algum tempo, assassinadas? A série de reportagens, que durou quinze dias, concluiu pela imprescindibilidade do trabalho educativo que incidisse sobre os arquétipos - "que constituem o ponto de junção entre o imaginário e os problemas racionais" ${ }^{121}$ - masculinos e femininos que povoam as mentes humanas desde o homo-sapiens, sem o que seria em vão a eficácia das importantes ações objetivas de um país de Primeiro Mundo.

Nas reflexões acerca da composição do imaginário, Alves $\left(2007\right.$, p. 46) ${ }^{122}$ enfatiza que

[...] a Psicologia e a Psicanálise já ensinaram que os lobos, as fadas, os ogros e os justiceiros habitam fora, a sociedade, e dentro de nós, compondo nosso imaginário e mesmo certos espaços da objetividade narrativa e das nossas relações sociais. Evidentemente, o reforço do imaginário é diametralmente oposto à construção objetiva do texto científico, pois este deve compor o imaginário dos leitores e espectadores não parecendo fazê-lo, visto que o imaginário costuma ficar fora dos cânones científicos, permanecendo, pois, no domínio do cotidiano, dos desejos sociais, da fabulação das gentes.

O consenso social e histórico na construção da imagem e mitos da identidade masculina e feminina, desde os primórdios, é fator preponderante na continuidade do "poder do macho". Não obstante as pressões para se alterar suas estruturas, seu enraizamento é extremamente profundo, exigindo uma incidência maior de ações de comunicação a distância. Segundo Vattimo (1992, p. 36) ${ }^{123}$,

\footnotetext{
121 DURAND, G. As estruturas antropológicas do imaginário. Tradução: Hélder Godinho. SP. Martins Fontes. $2^{\text {a }}$ ed. 2001. p.18

${ }^{122}$ ALVES, L. R. Ciência e mito na gestão internacional. INTERNEXT - Revista Eletrônica de Negócios Internacionais da ESPM, São Paulo, v. 2, n. 1, jan./jun. 2007, p.46. Também disponível em

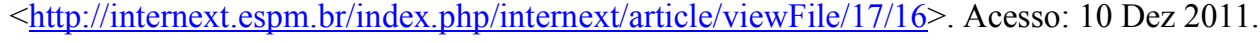

${ }^{123}$ Ibidem. p. 36
} 
[...] ao contrário do pensamento científico, o mito não é um pensamento demonstrativo, analítico, etc., mas narrativo, fantástico, envolvido nas emoções e, globalmente, tem menores ou nenhumas pretensões de objectividade; tem a ver com a religião e a arte, com o rito e a magia, e a ciência nasce, pelo contrário, em oposição a ele como desmitificação, 'desencanto do mundo'. O saber racional sobre a realidade, onde quer que procure constituir-se como consideração teorética e explicação do mundo, vê-se oposto não tanto à realidade fenomênica imediata, como à transfiguração mítica desta realidade. Muito antes do mundo se apresentar à consciência como um complexo de 'coisas' empíricas e de propriedades empíricas, apresentou-se como um conjunto de potências e de acções míticas.

[...] Mito significa, de facto, como se sabe, narração.

Mas, qual seria exatamente a diferenciação entre os termos mito, símbolo, arquétipo, esquema? Durand (ibidem, p. 62-63) ${ }^{124}$, ao explicar a palavra mito, consegue incorporar e diferenciar as demais. De forma sintética, mito pode ser definido como um sistema formado por esquemas, arquétipos e símbolos, compondo-se em narrativa:

[...] No prolongamento dos esquemas, arquétipos e simples símbolos podemos considerar o mito. Não tomaremos este termo na concepção restrita que lhe dão os etnólogos, que fazem dele apenas o reverso representativo de um ato ritual. Entenderemos por mito um sistema dinâmico de símbolos, arquétipos e esquemas, sistema dinâmico que, sob o impulso de um esquema tende a compor-se em narrativa. O mito é já um esboço de racionalização, dado que utiliza o fio do discurso, no qual os símbolos se resolvem em palavras e os arquétipos em idéias. 0 mito explica um esquema ou um grupo de esquemas. Do mesmo modo que o arquétipo promovia a ideia e que o símbolo engendrava o nome, podemos dizer que o mito promove a doutrina religiosa, o sistema filosófico ou, como bem viu Bréhier, a narrativa histórica e lendária. É o que ensina de maneira brilhante a obra de Platão, na qual o pensamento racional parece constantemente emergir de um sonho mítico e algumas vezes ter

${ }^{124}$ Ibidem. p. 62-63 
saudades dele. Verificaremos, de resto, que a organização dinâmica do mito correspondente muitas vezes à organização estática a que chamamos de 'constelação de imagens'. 0 método de convergência evidencia o mesmo isomorfismo na constelação e no mito.

A base de sustentação do desenvolvimento teórico de Durand (2001, p. 334) ${ }^{125}$ está alicerçada em algumas obras de Bachelard, principalmente em Psicanálise do Fogo. Dois terços do conteúdo do livro são dedicados a comprovar o desempenho efetivo da subjetividade na criação terrena, enaltecendo as ligações psicológicas e poéticas do fogo e da sexualidade, que desencadeia nos povos primitivos, através de um simples ato rítmico, a dança e o canto:

[...] 0 amor é a primeira hipótese científica para a reprodução objetiva do fogo. [...] Desde que se começa a esfregar, experimenta-se um calor doce e objetivo, ao mesmo tempo que a quente impressão de um exercício agradável.

Caso se quisesse buscar um significado sintético para a palavra "estruturas", termo-chave no título da grande obra de Durand sobre o imaginário, poder-se-ia dizer que seria “dinamismo". São constelações de imagens (a partir da concepção do sentido próprio, portanto, não são signos) que se movimentam e que o autor agrupa sua representação em dois regimes: o Regime Diurno - o masculino -, caracterizado pela antítese, “tem a ver com a dominante postural, a tecnologia das armas, a sociologia do soberano mago e guerreiro, os rituais da elevação e da purificação" (DURAND, 2001, p. 58) ${ }^{126}$. 0 Regime Noturno - o feminino -, marcado pelo eufemismo, pela antífrase, repetição e conversão,

\section{[...] subdivide-se nas dominantes digestiva e cíclica, a primeira}

\footnotetext{
${ }^{125}$ Ibidem. p.334

${ }^{126}$ Ibidem. p.58
} 
subsumindo as técnicas do continente e do hábitat, os valores alimentares e digestivos, a sociologia matriarcal e alimentadora; a segunda agrupando as técnicas do ciclo, do calendário agrícola e da indústria têxtil, os símbolos naturais ou artificiais do retorno, os mitos e os dramas astrobiológicos ${ }^{127}$.

Com mais profundidade, o autor explica, abaixo, a especificidade do sentido que quer dar à palavra "estruturas", fazendo-se importante sublinhar para o desenvolvimento desta pesquisa - a noção do dinamismo transformador do campo do imaginário, isto é, as constelações de imagens integrantes não são quantificáveis, mas sintomáticas, podendo, portanto, ser detectadas e alteradas:

[...] Enfim, este isomorfismo [ambiguidade dos valores] dos esquemas, arquétipos e símbolos no seio dos sistemas míticos ou de constelações estáticas levar-nos-á a verificar a existência de certos protocolos normativos das representações imaginárias, bem definidos e relativamente estáveis, agrupados em torno dos esquemas originais e a que chamaremos de estruturas. [...] 0 substantivo 'estrutura', acrescentado a atributos com sufixos tomados da etimologia da palavra 'forma', e que, na falta de melhor, utilizaremos metaforicamente, significará simplesmente duas coisas: em primeiro lugar que essas 'formas' são dinâmicas, ou seja, sujeitas a transformações por modificações de um dos termos, e constituem 'modelos' taxionômicos e pedagógicos, quer dizer, que servem comodamente para a classificação mas que podem servir, dado que são transformáveis, para modificar o campo do imaginário. Em segundo lugar, [...] esses 'modelos' não são quantitativos mas sintomáticos; as estruturas, tal como os sintomas na medicina, são modelos que permitem o diagnóstico e a terapêutica. ${ }^{128}$

Exemplo da materialização dos reflexos dos esquemas, arquétipos e símbolos durante a Idade Média é descrito por Georges Duby $\left(1989\right.$, p.97) ${ }^{129}$ - era

\footnotetext{
${ }^{127}$ Ibidem. p.58

${ }^{128}$ Ibidem. p.63-64 / 57-58

${ }^{129}$ DUBY, G. Idade Média, Idade dos Homens - do amor e outros ensaios. Tradução: Jônatas Batista Neto.
} 
conhecida como o período da história humana ocidental, com forte influência da Igreja sobre toda a sociedade. Caracterizada pelo modo de produção feudal, a Idade Média vai de 476 d.C até 1453, ano da conquista de Constantinopla pelos turcos otomanos e queda do Império Romano do Oriente:

[...] Toda a organização da sociedade civil funda-se sobre o casamento e sobre a imagem da casa, de uma casa onde só há um casal procriador e no interior da qual o poder e os papéis se dividem hierarquicamente entre o senhor e sua esposa. A mulher só alcança existência jurídica, só entra (podemos dizê-lo) na vida, casada, e ela sobe um degrau suplementar quando, no casamento, realiza aquilo para o qual ela foi tomada por um homem, quando dá à luz. Então, ela adquire um poder muito seguro, o da mãe sobre seu filho, sobre seus filhos, e que se desdobra quando ela se torna viúva. Em consequência, fora da célula doméstica, a mulher se encontra numa posição considerada perigosa. Não devem existir mulheres sozinhas, essas 'pobres' mulheres privadas desse poder que é, de fato, o reflexo do poder exercido pelo homem sobre elas. Quanto a essas mulheres solitárias, a sociedade se esforça por reuni-las em instituições de isolamento e de proteção, organizadas igualmente como 'casas', casas alternativas: são os mosteiros, as comunidades benignas, mas também os bordéis.

Em outra obra, Duby $(1997, \text { p. } 21)^{130}$ destaca a "aura" que envolvia a mulher no século XII:

[...] o poder, o misterioso, o inquietante, o incontestável poder das mulheres se deve principalmente a que, como da terra fértil, a vida sai de suas estranhas e, quando a vida se extingue, retorna para elas como para a terra acolhedora. As duas funções da feminilidade, materna e funerária, designavam, ao que parece, a dama para reger as 'obséquias', os serviços que os ancestrais exigiam dos vivos.

São Paulo: Companhia das Letras, 1989. p. 97.

${ }^{130}$ Idem. Damas do Século XII - A Lembrança das Ancestrais. Tradução: Maria Lúcia Machado. São Paulo: Companhia das Letras, 1997, p. 21. 


\subsection{O tear e a trama das relações humanas}

E, nesse emaranhado dinâmico das estruturas do imaginário, vão se tecendo laços que podem ser fortalecidos - no sentido de perpetuar as desigualdades de gênero - ou afrouxados, visando desfazer os moldes dos papéis estabelecidos pela dinâmica social. É pelo trabalho educativo e de comunicação a distancia, que transforma seres humanos em agentes políticos, que se consegue alterar os condicionamentos provocados por mitos e imagens, além de se considerar que as mídias digitais trazem a perspectiva de novas dinâmicas de representação da mulher, foco este a ser trabalhado mais adiante.

Essas 'verdades' estão presentes na construção cultural de gênero, que é tecida a partir das diversas redes de relações na vida de uma pessoa: família, Igreja, escola, associações populares, partidos políticos, meios de comunicação de massa... A antropóloga feminista Jeanine Anderson (1997, p. 14-18) ${ }^{131}$ desenvolveu um profundo estudo sobre as redes de atores que vão tecendo os sistemas de gênero, classificando-os em quatro faces:

[...] Um sistema de gênero pode ser concebido como um diamante lapidado que, sendo único, tem várias faces. (1) sistemas de classificação [categorias linguísticas e mentais mulher e homem, com as diferenciações sociais que se somam ao leque de conceitos e abstrações; uma organização cognitiva do mundo]; (2) sistemas de relações, especialmente relações de poder, entre pessoas e grupos [em combinação com outros critérios e princípios de ordenamento e hierarquização: raça, cultura, região, nacionalidade, idade, geração, entre outros; para criar uma ordem social que distribui - desigualmente - recursos e que canaliza a ação dos diferentes atores]; (3) sistemas de regras [comportamentos que são prescritos e proscritos, os primeiros estimulados e até impostos como obrigação e os outros sancionados e proibidos; como todo sistema de regras sociais, o de gênero vive na constante reafirmação das regras da dinâmica

\footnotetext{
131 ANDERSON, J. Sistemas de gênero, redes de atores e uma proposta de formação. Tradução: Beatriz Cannabrava. REPEM/CEAAL. Uruguai. 1997. p.14-18
} 
social diária]; e (4) sistemas de intercâmbio entre atores [situações de interdependência, especialmente quando os bens envolvidos na transação são de diferente natureza - a 'solidariedade orgânica' nas palavras de Durkheim].

Apesar do avanço significativo na condição de vida da mulher, que se intensificou nas últimas décadas graças ao impulsionamento dado pelo movimento feminista, permanece o impasse na busca da igualdade na divisão dos espaços público e privado, o que demonstra a permanência das imagens e mitos que cultuam, de forma efervescente, a identidade masculina e feminina. Essa realidade que vem sendo construída pelos seres humanos ao longo dos tempos traduz-se em ações que são acionadas pela eficácia do imaginário. Ao contrário da cultura, que pode ser detectada com clareza nas formas de organização de uma sociedade,

[...] o imaginário permanece uma dimensão ambiental, uma matiz, uma atmosfera, aquilo que Walter Benjamim chama de aura, [...] que ultrapassa e alimenta a cultura; [...] é uma força social de ordem espiritual, uma construção mental [...] (MAFFESOLI, 2001, p.75-76) ${ }^{132}$.

Mas, se para os psicanalistas o imaginário é sinônimo de recalcamento, pode-se, felizmente, inspirar e agir com base em Bachelard, para quem o imaginário é origem de libertação. Faz-se importante a definição abaixo (DURAND, 2001, p. 342) ${ }^{133}$, para que, posteriormente, se possa comparar a metáfora da árvore e a do axioma, que vem sendo desenvolvida por teóricos voltados para a alteração trazida pelas TIC:

[...] Bachelard pretende que a 'imaginação é uma árvore'. Nada é, assim, mais fraterno e lisonjeiro para o destino espiritual ou temporal do homem [!] que se comparar a uma árvore secular,

\footnotetext{
${ }^{132}$ Ibidem. p.75-76

133 DURAND, G. As estruturas antropológicas do imaginário. Tradução: Hélder Godinho. SP: Martins Fontes. $2^{\mathrm{a}}$ ed. 2001 . p. 342
} 
contra a qual o tempo não teve poder, com a qual o devir é cúmplice da majestade das ramagens e da beleza das florações.

Da mesma forma que a cultura não é individual, o imaginário só existe coletivamente, como "estado de espírito de um grupo, de um país, de um Estado-nação, de uma comunidade, etc. O imaginário estabelece vínculo. É cimento social. Logo, se liga, une numa mesma atmosfera, não pode ser individual (MAFFESOLI, 2001, p. 76) ${ }^{134}$.

Durand (2001, p. 97) ${ }^{135}$ relativiza tal afirmação, ao destacar que

[...] ninguém melhor do que o grande sociólogo Roger Bastide evidenciou, na mitocrítica do famoso escritor André Gide, o confronto dos mecanismos desta tensão sistêmica numa psique (é inútil mencionar se é 'coletivo' ou 'individual', pois estas duas nuanças apagam-se no trajeto antropológico) situada entre um imaginário atualizado e um imaginário potencializado.

A interatividade proporcionada pelo imaginário só é possível pela via da emoção, característica demasiadamente carregada de aspectos femininos portanto, estigmatizada pela fragilidade -, para ter sido contemplada pelo pensamento baseado na racionalidade. Daí a importância que se deve dar aos aspectos simbólicos no desenvolvimento de estratégias de comunicação a distância, a serem vivenciadas por pessoas que se caracterizam por distintos sujeitos sociais, mas, agregados, coletivamente, por uma aura, uma atmosfera, um estado de espírito. Essas pessoas buscam o objetivo comum de avançar na luta pela equidade de gênero, formando um grupo social interessado na construção de uma nova sociedade. Deve-se considerar, portanto, a premissa de que esse grupo social é uma das fontes de mediação, que é potencializadora da transformação social, através da leitura crítica e da intervenção comunicacional,

\footnotetext{
${ }^{134}$ Ibidem. p. 76

${ }^{135}$ DURAND, G. O imaginário - ensaio acerca das ciências e da filosofia da imagem. Tradução: René Eve Levié. RJ: Difel. 2 ed. 2001.p. 97
} 
por um processo de construção coletiva do conhecimento que oferece sustentação para a atuação política e envolvimento de novos agentes. Como bem observa Arturo Matute (1992, p. s/nº $)^{136}$,

[...] se o primeiro contato apela à emoção, o tema entra na esfera do conhecimento integrado na vida de quem aprende, além desse contato acompanhar o curso de uma atividade mediante sucessivas 'devoluções criativas' paralelas ao aprofundamento intelectual [...].

O empenho em se aprofundar teoricamente no tema do imaginário explicase não somente pelo fato de os paradigmas ocidentais estarem em crise, mas pela relação direta que possui no enfoque da comunicação a distancia, diante da possibilidade de novas dinâmicas na construção da representação da mulher oferecida pelas mídias digitais, o que será aprofundado ao final deste trabalho.

A importância do campo do imaginário na construção da realidade parece caminhar para um consenso, principalmente a partir dos anos 1970, quando ocorre uma dedicação mais profunda ao tema por parte de pesquisadores da Escola de Grenoble: Jacques Bril escreve a tese Simbolismo e civilização ensaio sobre a eficácia antropológica do imaginário; Pierre Sansot, com As formas sensíveis da vida social, A poética da cidade e As variações paisagísticas; Michel Maffesoli, que resgata a tradição de Gaston Bachelard e Gilbert Durand, com $A$ conquista do presente: para uma sociologia da vida cotidiana, $A$ transfiguração do político: a tribalização do mundo, A contemplação do mundo e $O$ instante eterno.

[...] Para esta corrente sociológica original convergirá a sociologia denominada de 'as histórias de vida' na qual a investigação do

\footnotetext{
${ }^{136}$ MATUTE, A. El metodo de acercamiento crítico. La calidad en el proceso educativo. In: Educacion para la comunicacion - manual latinoamericano de educación para los medios de comunicación. Chile. Ceneca, Unesco e Unicef. 1992
} 
sociólogo cede diante do imaginário recitativo e representante de uma amostragem de um grupo social. Finalmente, com Cornelius Castoriadis ou Georges Balandier, as razões políticas dos poderes aparentes serão tão racionalizadas que se destacarão sobre um fundo imaginário mais ou menos passional. Nas sociologias recentes há um esforço para um 'reencantamento' (Bezauberung) do mundo da pesquisa e seu objeto ('social' e 'societal' - *N.T.: o impacto no nível da sociedade; as dificuldades econômicas, sociais ou ambientais, de natureza setorial ou regional), tão desencantado pelo conceptualismo e as dialéticas rígidas e unidimensionais dos positivistas. E este 'reencantamento' passa acima de tudo pelo imaginário, o lugar-comum do próximo, da proximidade e do longínquo 'selvagem'. A partir de agora, a sociologia passará a ser 'figurativa' (P.Tacussel), fundamentandose num 'conhecimento comum' (M. Maffesoli) onde sujeito e objeto formam um só no ato de conhecer e no qual o estatuto simbólico da imagem constitui o paradigma (o modelo perfeito, a demonstração satisfatória pelo exemplo). ${ }^{137}$

A partir de meus estudos nas obras de Durand, observo que o autor louva o atual avanço da ciência do imaginário, mas conclui catastroficamente, em função do efeito perverso do vídeo, comparando-o à invenção e utilização da bomba atômica. O caráter restrito de tal entendimento, infelizmente, só serve para transmitir um sentimento de impotência em leitores/as que não tiveram a oportunidade de alargar horizontes nesse complexo tema. Além disso, o pessimismo de tal conclusão é contraditório com o desenvolvimento de seu pensamento, já que destaca o dinamismo das estruturas do imaginário, portanto, passíveis de mudanças e transformações sociais. Acrescente-se que não condiz com a profunda poética de uma de suas frases: “Nós que acabamos de dar um lugar tão belo à imaginação pedimos modestamente que se saiba dar lugar à cigarra ao lado do frágil triunfo da formiga", e muito menos com a recomendação de que “impõe-se então uma educação estética, totalmente humana, como educação fantástica à escala de todos os fantasmas da

\footnotetext{
${ }^{137}$ DURAND, G. O imaginário - ensaio acerca das ciências e da filosofia da imagem. Tradução: René Eve Levié. RJ. Difel. $2^{\mathrm{a}}$ ed. 2001. p.55-56-57
} 
humanidade" (DURAND, 2001, p. 430) $)^{138}$.

Esta pesquisa, como se pode ver, vem mostrando um entendimento que considera as imagens midiáticas sem o poder de anestesiar as pessoas, dada a não passividade de quem recebe as mensagens, contrariamente à conclusão catastrófica a que chega Durand (2001, p. 118-119) ${ }^{139}$ :

[...] a imagem 'enlatada' paralisa qualquer julgamento de valor por parte do consumidor passivo, já que o valor depende de uma escolha; o espectador então será orientado pelas atitudes coletivas da propaganda: é a temida 'violentação das massas'. Este nivelamento é perceptível no espectador de televisão, que engole com a mesma voracidade, ou melhor, com a mesma falta de apetite, espetáculos de 'variedades', discursos presidenciais, receitas de cozinha e notícias mais ou menos catastróficas... É o mesmo 'olho de peixe morto' que contempla as crianças que morrem de fome na Somália, a 'purificação étnica' na Bósnia ou o arcebispo de Paris subindo a escadaria da Basílica de Montmartre carregando uma cruz... Esta anestesia de criatividade do imaginário e o nivelamento de valores, numa indiferença espetacular, são reforçados por outro e último perigo. Trata-se do anonimato da 'fabricação' destas imagens.

Ao tornar relevante o poder de ressignificação das mensagens por parte da audiência, alicerçada na contribuição dos estudos culturais, esta pesquisa acata o entendimento de que os estereótipos discriminatórios podem ser enfraquecidos ou potencializados, dependendo da incidência em termos de comunicação a distância. Essa estratégia precisa considerar que os lugares comuns sejam constantemente revisitados para que se possa vislumbrar a alteração das estruturas estereotipadas. Para Silverstone (2005, p. 70-71) ${ }^{140}$,

\footnotetext{
${ }^{138}$ DURAND, G. As estruturas antropológicas do imaginário. Tradução: Hélder Godinho. SP. Martins Fontes. $2^{\mathrm{a}}$ ed. 2001. p.430

${ }^{139}$ DURAND, G. O imaginário - ensaio acerca das ciências e da filosofia da imagem. Tradução: René Eve Levié. RJ. Difel. $2^{a}$ ed. 2001. p.118-119

${ }^{140}$ SILVERSTONE, R. Por que estudar a mídia? Tradução: Milton Camargo Mota. Edições Loyola. SP. $2^{\mathrm{a}}$.ed. 2005. p.70/71.
} 
[...] No cerne da persuação, e nas raízes da retórica, estão os lugares-comuns, os topoi, sem os quais não pode haver conexão, sem os quais não pode haver criação: nem memória, nem invenção. Os lugares-comuns são aquelas ideias e valores, molduras do significado, compartilhados e compartilháveis por falantes e ouvintes. São o familiar sobre o qual se baseia o novo, o óbvio e dado-por-certo sobre o qual se formam surpresas e se solicita atenção. Eles recorrem às compreensões e lembranças compartilhadas dos participantes, mas permitem a essas lembranças ser desafiadas e reformadas. Os lugares-comuns são onde a retórica encontra e explora o senso comum, às vezes pelo clichê, amiúde pelo estereótipo, formando uma estrutura de cognição e recognição sem a qual as tentativas de persuação resultam em nada. [...] Os lugares-comuns são os símbolos compartilhados de uma comunidade.

Mas, qual é de fato o significado da palavra estereótipo? Uma vez mais, esta pesquisadora se remete às aulas já citadas da profa. Maria de Lourdes Motter, do Núcleo Cotidiano e Linguagem (USP/ECA). Ela enfatizava que a necessidade que o ser humano tem de atribuir sentido às coisas leva a uma produção de estereótipos, cuja característica básica é a simplificação para se ter um sentido, isto é, o ser humano necessita de certa familiaridade, por isso, acaba por adquirir certo automatismo num primeiro momento. Segundo Bosi (2004, p. 113-115) $)^{141}$,

[...] Onde queríamos estampar a fisionomia viva do narrador, imprimimos os traços secos da máscara. É o gesso do estereótipo que perpetua lembranças enquanto as imobiliza e resume. [...] Mas entre as travessias forçadas e os percursos imprevistos, existe a preciosa noção do caminho familiar, com marcos onde a significação da vida se concentra. [...] Essa colheita perceptiva, relação de trabalho e de escolha entre o sujeito e o seu objeto, pode sofrer um processo de facilitação e de inércia. Isto é, colhem-se aspectos do real já recortados e confeccionados pela cultura. 0 processo de estereotipia se apodera da nossa vida

\footnotetext{
${ }^{141}$ BOSI, E. Entre a opinião e o estereótipo. In: O tempo vivo da memória - Ensaios de Psicologia Social. Ateliê Editorial. SP: 2004. $2^{\mathrm{a}}$ ed. p.113/4/5
} 
mental.

Como se vê, os estereótipos funcionam como uma orientação em nossas vidas, mas devem ser provisórios, pois seu domínio na mente humana pode impedir a abertura para o conhecimento do outro. Uma pessoa que se droga, um homossexual, um negro, uma mulher, um judeu, uma pessoa do chamado Terceiro Mundo, certamente, são seres humanos que vão muito além do estigma que os persegue. Os preconceitos têm uma estreita relação com os estereótipos. O preconceito é a categoria do pensamento e do comportamento cotidianos, com caráter momentâneo, superficial e genérico. 0 pensamento cotidiano implica também em comportamento. Por um lado, assumimos estereótipos, analogias e esquemas já elaborados, e, por outro, eles nos são impingidos, desde crianças, o que desencadeia uma relação afetiva com eles. Segundo Bakhtin (1999, p. 1256) ${ }^{142}$,

[...] A enunciação realizada é como uma itha emergindo de um oceano sem limites, o discurso interior. As dimensões e as formas dessa ilha são determinadas pela situação da enunciação e por seu auditório. [...] A fórmula estereotipada adapta-se, em qualquer lugar, ao canal de interação social que the é reservado, refletindo ideologicamente o tipo, a estrutura, os objetivos e a composição social do grupo.

\subsection{A representação da mulher na mídia}

Partindo-se da constatação de que realidade é construída a partir de aspectos objetivos e subjetivos, o exercício de atentar para as consequências das mensagens discriminatórias é tarefa de quem busca promover a cidadania para um mundo melhor, com valores éticos, de equidade e justiça social. Na chamada era digital, onde prevalece o slogan “estou na mídia, logo, existo!”, a população

\footnotetext{
142 Ibidem. p. $125 / 6$
} 
brasileira pode encontrar referenciais de identidade que não reforcem as relações de subordinação que são impostas às pessoas fora do modelo ocidental: homem, branco, magro, sem deficiências, jovem, heterossexual, culto, e que vem sendo construído ao longo dos milênios.

As mulheres vêm conseguindo grandes conquistas no espaço público, mas ainda encontram muitas dificuldades para desconstruir os mitos da identidade feminina "a la Barbie", a boneca que apresenta padrões irreais de beleza. Não se trata de puro discurso de movimentos sectários, mas uma realidade cruel facilmente demonstrável por estatísticas já apresentadas no capítulo 4, comprovando uma conquista desproporcional de poder e oportunidade baseada na tríade classe-gênero-raça. De acordo com Saffioti (2004, p. 125) ${ }^{143}$,

\footnotetext{
"Retomando o nó (Saffioti, 1985), difícil é lidar com esta nova realidade, formada pelas três subestruturas: gênero, classe social, raça/etnia, já que é presidida por uma lógica contraditória, distinta das que regem cada contradição em separado. Uma voz menos grave ou mesmo aguda de uma mulher é relevante em sua atuação, segundo o preconceito étnico-racial, e, mais seguramente, na relação de gênero e na de classes sociais. 0 importante é analisar estas contradições na condição de fundidas ou enoveladas ou enlaçadas em um nó. Não se trata da figura do nó górdio nem apertado, mas do nó frouxo, deixando mobilidade para cada uma de suas componentes (Saffioti, 1998). Não que cada uma destas contradições atue livre e isoladamente. No nó, elas passam a apresentar uma dinâmica especial, própria do nó. Ou seja, a dinâmica de cada uma condiciona-se à nova realidade, presidida por uma lógica contraditória (Saffioti, 1988). De acordo com as circunstâncias históricas, cada uma das contradições integrantes do nó adquire relevos distintos. E esta motilidade é importante reter, a fim de não se tomar nada como fixo, aí inclusa a organização destas subestruturas na estrutura global, ou seja, destas contradições no seio da nova realidade novelo patriarcado-racismo-capitalismo (Saffioti, 1987) historicamente constituída."
}

\footnotetext{
${ }^{143}$ Ibidem. p. 125
} 
A materialização das discriminações de gênero, classe e raça é facilmente perceptível em nossa sociedade, como, por exemplo, quando se observa quem compõe as estruturas de poder político (executivo, legislativo e judiciário) ou econômico (proprietários de empresas e ocupantes de cargos executivos). Entre as 100 maiores empresas brasileiras apenas cinco delas têm mulher na presidência; até 2009, não havia nenhuma. ${ }^{144}$ Naquela que é considerada a melhor universidade brasileira, a USP, que em 2011 voltou a integrar a lista das 200 melhores universidades do mundo, basta entrar em uma sala de aula e constatar uma maioria de estudantes de cor branca e pertencente à classe média e alta. Foram essas famílias que tiveram a oportunidade de ter seus filhos cursando bons colégios particulares, preparando-os para ingressar em uma universidade pública de renome. Em termos de gênero, a educação é uma das poucas áreas em que as mulheres conseguiram ultrapassar os homens nos cursos de graduação e pós-graduação. De acordo com levantamento do Instituto Nacional de Estudos e Pesquisas Educacionais (Inep), vinculado ao Ministério da Educação (MEC), elas representam $56 \%$ do número de matriculados e $62 \%$ do número que concluem o curso superior. Em termos mundiais, de acordo com a ONU, as mulheres representam 51\% do total de universitários.

Voltando aos padrões estereotipados, o primeiro passo para alterar essa realidade é conscientizar-se de que, ao romper com as discriminações na linguagem escrita e imagética, avança-se na influência do modo de percepção da realidade pelas pessoas, quebrando-se padrões comportamentais. Soma-se a isso, a adoção de mecanismos de intervenção, que levam, sem sombra de dúvidas, a resultados positivos ao considerarmos que vivemos em um mundo onde as forças

\footnotetext{
${ }^{144}$ De acordo com artigo publicado no jornal Folha de S.Paulo, em 28/01/2011, no caderno Mercado, p.B1, no Brasil, nas empresas de médio e grande porte, há 3\% de mulheres presidentes (nos EUA, também 3\%); $9 \%$ de diretoras e vice-presidentes (nos EUA, 25\%); 35\% de gerentes (nos EUA, 50\%); 50\% de trainees e analistas (nos EUA, 55\%). A média global de mulheres em cargos de gerência sênior, considerando-se as 36 maiores economias, é de menos de $25 \%$. No mundo todo, apenas 20 mulheres são chefes de Estado (presidentas ou primeiras-ministras); 2 agências da ONU têm mulheres no comando (Unesco e OMS) [Nota da pesquisadora: faltou mencionar a ONU Mulheres (Entidade das Nações Unidas para a Igualdade de Gênero e Empoderamento das Mulheres), presidida por Michelle Bachelet, ex-presidente do Chile]. No Brasil, 57 mulheres forma eleitas ou reeleitas para o Congresso, de um total de 594. (fontes utilizadas pela FSP: CWWL, ONU, Forbes, federações olímpicas, Lidem, Ranking Exame dos 500).
} 
de mercado tentam se equilibrar ao sofrer pressão de um público com consciência cidadã.

Williams (1992, p. 216-217) ${ }^{145}$ fornece um entendimento ponderado e associativo das diferentes forças atuantes na produção cultural, ao afirmar que

“[...] as funções discerníveis de produtores culturais jamais podem ser compreendidas separadamente dessa produção e reprodução geral de que participam todos os membros da sociedade. Ao mesmo tempo, essa participação é, em grande medida, social e historicamente variável. Sua condição mínima é a posse e a reprodução de uma língua e de costumes e, nesse sentido, é quase sempre efetivamente geral. Mas, por outro lado, há todos os graus de dominação e subordinação práticas, entre conquistadores e conquistados, entre classes sociais, entre os sexos, entre adultos e crianças. Dentro de tais relações de dominação e subordinação práticas, é inevitável que as atividades de produtores culturais se tornem duplamente especializadas: em determinado tipo de trabalho cultural, mas também em relações específicas dentro do sistema social organizado.

[...] os grupos dominantes nem sempre controlam (historicamente, de fato, muitas vezes não o fazem) o sistema de significações global de um povo; tipicamente são antes dominantes dentro dele do que sobre e acima dele.

A questão dos estereótipos na linguagem escrita e imagética vem merecendo ênfase nas ações do movimento feminista, como bandeira fundamental para o avanço da luta, tanto que, a partir de 1991, a Repem passou a designar o dia 21 de junho, com uma série de atividades, como a data "Por uma educação sem discriminação”.

E Paulo Freire, ao publicar, em 1992, A pedagogia da esperança - um reencontro com a Pedagogia do oprimido ${ }^{146}$ faz uma análise do volume imenso de cartas que recebeu em Genebra, com críticas de mulheres norte-americanas,

\footnotetext{
${ }^{145}$ WILLIAMS, R. Cultura. São Paulo: Paz e Terra. 1992. p. 216/7.

${ }^{146}$ FREIRE, P. Pedagogia da Esperança - um reencontro com a Pedagogia do Oprimido. RJ: Paz e Terra. $7^{\mathrm{a}}$ ed. 2000. p. 66-67-68
} 
depois do lançamento do livro, em sua primeira edição no início de 1971, em função da linguagem sexista. Eram tempos de exílio, dado o longo regime militar brasileiro, e a primeira edição foi publicada em inglês.

[...] É que, diziam elas, com suas palavras, discutindo a opressão, a libertação, criticando, com justa indignação, as estruturas opressoras, eu usava, porém, uma linguagem machista, portanto discriminatória, em que não havia lugar para as mulheres. [...] Em certo momento de minhas tentativas, puramente ideológicas, de justificar a mim mesmo, a linguagem machista que usava, percebi a mentira ou a ocultação da verdade que havia na afirmação: 'Quando falo homem, a mulher está incluída'. E por que os homens não se acham incluídos quando dizemos: 'As mulheres estão decididas a mudar o mundo'? [...] A discriminação da mulher, expressada e feita pelo discurso machista e encarnada em práticas concretas é uma forma colonial de tratá-la, incompatível, portanto, com qualquer posição progressista, de mulher ou de homem, pouco importa. [...] A recusa à ideologia machista, que implica necessariamente a recriação da linguagem, faz parte do sonho possível em favor da mudança do mundo. [...] Não é puro idealismo, acrescente-se, não esperar que o mundo mude radicalmente para que se vá mudando a linguagem. Mudar a linguagem faz parte do processo de mudar o mundo. A relação entre linguagem-pensamento-mundo é uma relação dialética, processual, contraditória.

As conclusões a que chegou Paulo Freire remetem a Bakhtin (1999, p. $35 / 41)^{147}$, que se aprofundou na relação da linguagem e da cultura, considerada enquanto relação de causa e efeito, isto é bilateral: trata-se da influência da cultura sobre a linguagem, como da ação da linguagem sobre o desenvolvimento da cultura:

[...] A consciência adquire forma e existência nos signos criados por um grupo organizado no curso de suas relações sociais. [...] As palavras são tecidas a partir de uma multidão de fios ideológicos e servem de trama a todas as relações sociais em todos os domínios.

${ }^{147}$ Ibidem. p. 35/41 
Não se pode negar que as mensagens dos meios de comunicação exercem influência na construção do imaginário. No caso da televisão, que é o meio de informação e entretenimento da maioria da população brasileira, está claro que a programação - regida pelos índices de audiência, em função das verbas publicitárias - é tanto mais lucrativa quanto maior for o conteúdo violento e discriminatório. Entretanto, o crescimento da violência no Brasil encontra uma explicação muito mais plausível no problema estrutural da desigualdade social (uma minoria muito rica e a maioria extremamente pobre). Há países africanos como Gana, onde a pobreza é socialmente distribuída - que possuem índices de violência comparáveis aos de países do Primeiro Mundo. Na opinião da professora Elza Dias Pacheco $(2000)^{148}$, coordenadora do Laboratório de Pesquisas sobre Infância, Imaginário e Comunicações (Lapic) da USP/ECA,

[...] era necessário investigar mais, observar melhor para desmistificar concepções apocalípticas e reducionistas sobre a relação TV/criança, originárias, em parte, de uma óptica adultocêntrica. Era necessário procurar bem não a explicação duvidosa da vida, mas a poesia explicável da vida. Conforme Jung, a fantasia tem tanto de sentimento como de reflexão, e uma parcela idêntica de intuição e sensação.

A capacidade de reflexão - de ressignificação - das pessoas, conforme bem enfatiza Barbero (1997) ${ }^{149}$, situa-se exatamente no campo das mediações, quer dizer, além da emissão e recepção, existe um processo de diálogo interior, cujos sentidos se completam no jogo ideológico das experiências culturais e sociais.

E fácil imaginar a força da linguagem audiovisual em uma população tão imensa quanto a brasileira e com baixo nível de escolaridade. Se por um lado a

\footnotetext{
${ }^{148}$ PACHECO, E. D. LAPIC: espaço lúdico de conhecimento sobre TV/criança. In: Revista Comunicação e Educação. no.19. SP. ECA-USP/Editora Segmento. 2000

${ }^{149}$ MARTIN-BARBERO, J. Dos meios às mediações - comunicação, cultura e hegemonia. RJ: Editora UFRJ. 1997
} 
forma de construção desses novos sentidos é impregnada de uma linguagem complexa, que remete o lúdico para a espetacularização, há que se relevar a eficácia dos meios de comunicação, que transmitem informações de forma mais absorvente, antecipando a aprendizagem. A mídia é, pois, portadora de informações e representações do mundo a serem analisadas, comparadas e reconstruídas. Além do mais, como observa Maffesoli (2001, p. 76-77) ${ }^{150}$

[...] não é a imagem que produz o imaginário, mas o contrário. A existência de um imaginário determina a existência de conjuntos de imagens. A imagem não é o suporte, mas o resultado. [...] Evidentemente que a prática condiciona as construções do espírito, mas estas também influenciam as práticas.

Este capítulo caminha no sentido de entrelaçar o potencial do imaginário com o processo de construção/desconstrução dos arquétipos de discriminação. Para tanto, leva em conta a força cada vez maior das imagens disseminadas pelos meios de comunicação de massa, ao mesmo tempo em que considera as novas dinâmicas comunicacionais propiciadas pelas mídias digitais, o que vem acarretando diferenças na representação da mulher, no sentido de romper com estereótipos. Trata-se de um esforço na continuidade ao aprofundamento teórico de conceitos conectados ao objeto de pesquisa. São abordagens consideradas importantes para uma trajetória que pretende desembocar - após um olhar sobre o impacto temporal e espacial das novas tecnologias sobre o ser humano, com as interferências no processo de construção de novas relações sociais de gênero - no enfoque mais específico da imprescindível relação da comunicação com as estratégias de avanço das causas feministas, particularmente na questão da violência doméstica, considerada a consequência que mais fortemente expressa a milenar construção social de gênero que coloca a mulher em condição de subordinação ao homem.

\footnotetext{
${ }^{150}$ Ibidem. p. 76-77
} 


\subsection{A violência real e a simbólica}

Em breve, estrearia na TV Globo, no horário nobre da emissora líder de audiência, mais uma novela de Manoel Carlos, autor mais conhecido como um cronista da vida cotidiana. A nova novela das $8 \mathrm{~h}$ (que passou a ir ao ar às $9 \mathrm{~h}$ da noite), Viver a Vida ${ }^{151}$ abordaria "histórias de superação em todas as áreas: no amor, na saúde, no trabalho e na família" ${ }^{152}$. O autor enfatizou ter

[...] uma linha de comportamento para tratar do cotidiano, de pessoas e de relações familiares, fundamentalmente. Em minhas novelas não existe uma história central, absoluta. 0 que existe é um tema central que, em 'Viver a Vida', será o problema geral de superação. Na vida, não há beco sem saída, e é isso que defendo na novela. A pessoa pode perder tudo, menos a esperança"153.

Repetindo uma fórmula de sucesso de sua novela anterior, Laços de Família, ao final de cada capítulo haveria um depoimento com "histórias diversas de superação". Foi quando a produção do programa enviou uma mensagem eletrônica para a ONG Rede Mulher de Educação, na qual esta doutoranda atua, procurando voluntárias que quisessem fornecer depoimento de superação relacionado à grave problemática da violência doméstica. Estava aí uma oportunidade ímpar de incidir na mídia, tratando de um assunto da maior importância para a luta feminista. 0 convite foi espalhado para as educadoras da entidade Brasil afora, assim como para lideranças de organizações do movimento de mulheres e do movimento feminista, na certeza de encontrar voluntárias tanto entre elas, como entre o público com quem trabalham. Mera empolgação

\footnotetext{
${ }^{151}$ A novela Viver a Vida totalizou 209 capítulos, indo ao ar de 14/09/2009 a 14/05/2010. Em seu elenco estiveram Taís Araújo (protagonista negra, pela primeira vez na história da telenovela brasileira), José Mayer, Lília Cabral, Thiago Lacerda, Alinne Moraes (que viveu o drama de se tornar tetraplégica), Mateus Solano e Giovanna Antonelli, entre outros. De autoria de Manoel Carlos, com colaboração de Ângela Chaves, Cláudia Lage, Daisy Chaves, Juliana Peres e Maria Carolina. A direção é de Teresa Lampreia, Frederico Mayrink, Luciano Sabino, Leonardo Nogueira, Adriano Mello e Maria José Rodrigues. Tem direção-geral de Jayme Monjardim e Fabrício Mamberti, e direção de núcleo de Jayme Monjardim.

${ }^{152}$ Disponível em <http://www.tvmagazine.com.br/blogs/post.asp?ID=1874> . Acesso: 22 maio 2011.

${ }^{153}$ Idem.
} 
inicial! Eu - Vera Vieira - e Lucilene Cruz, do Grupo de Mulheres Assentadas de Sumaré, fomos as únicas que se propuseram a dar o depoimento, com a certeza de que se poderia levar a mensagem de que é possível sair de uma relação violenta e viver uma vida mais feliz, para milhões de brasileiras e brasileiros deste país, e de outros atingidos pela emissora.

Particularmente, vi nesse depoimento ${ }^{154}$ uma maneira de - ao falar com sinceridade e com o coração para que a mensagem fosse capturada pela via da emoção - conseguir um impacto de grande vulto no tempo de $1 \mathrm{~m} 6 \mathrm{~s}$, que fosse muito além daquele conseguido em todo o meu percurso passado, presente e futuro. Concentrei o foco da mensagem na relevância de quebrar o silêncio, fazendo com que a violência saia das quatro paredes, pois este é um passo que representa meio caminho andado no processo de rompimento deste ciclo. A novela estreou em 14/9/2009, alcançando uma média de 43 pontos de audiência, com picos de 45 , índices ${ }^{155}$ considerados recordes em um capítulo inicial. Meu depoimento foi ao ar logo no início da novela, no capítulo de 25/9/2009. Não tenho dúvidas sobre a conquista do intento de ter tocado o coração e as mentes de um público incalculável! Além disso, a versão estendida do depoimento, com três minutos de duração, e um artigo relatando a história da depoente foram inseridos no Portal da Superação ${ }^{156}$, espaço criado levando-se em conta as tecnologias da informação e comunicação, que têm na internet a sua maior expressão.

É muito interessante analisar as nuances dos inúmeros retornos de pessoas do Brasil e do exterior (como Canadá, Estados Unidos e Japão), que assistiram ao depoimento, indo desde congratulações até certo constrangimento e estranhamento - principalmente por parte de feministas. Algumas delas fizeram questão de frisar que viram o depoimento “por acaso, zapeando canais”, em uma

\footnotetext{
${ }^{154}$ Disponível em http://mulherespaz.org.br/site/index.php?option=com_content\&view=article\&id=143:veravieira-depoimento-viver-a-vida\&catid=57:artigos\&Itemid=152. Acesso: 4 Fev 2012.

155 "Novela Viver a Vida Estreia dia 24 de Setembro", post de 27/08/2009. Disponível em: $<$ http://www.tvmagazine.com.br/blogs/post.asp?ID=1874>. Acesso: 20 nov. 2011.

${ }^{156}$ Disponível em <http://especial. viveravida.globo.com/portal-da-superacao/>. Acesso: 20 set 2011.
} 
nítida demonstração da dificuldade que o movimento feminista tem em lidar com os meios de comunicação de massa e sua influência. Se por um lado, vivenciei a sensação gratificante de ouvir um motoboy reforçar a importância do depoimento e assumir que era "o maior noveleiro", por outro, a reação de algumas feministas me levou a refletir sobre até que ponto elas não estariam, contraditoriamente, endossando o ditado popular "em briga de marido e mulher, não se mete a colher".

Esse ditado remete aos anos 1970, ocasião em que houve um forte movimento pela defesa da vida das mulheres, intitulado quem ama não mata. Faz-se importante relatar os fatos ocorridos e a forma de abordagem dos meios de comunicação de massa, na época, dada a importância de ambas as temáticas para esta tese: comunicação e feminismo - com recorte na questão da violência doméstica, e a percepção das alterações que vêm ocorrendo na abordagem pela mídia. Em 30 de dezembro de 1976, Doca Street assassinou Ângela Diniz, com quatro tiros, no Balneário de Búzios, Rio de Janeiro, por não aceitar a separação de um relacionamento de apenas três meses, permeado por um cotidiano com cenas de ciúmes, agressão e violência da parte dele, segundo relatos da família dela. Ele, Raul Fernandes do Amaral Street, então com 42 anos, atuava como corretor de ações, mas tinha a fama estigmatizada de gigolô e traficante. Ela, então com 32 anos, era uma socialite conhecida como a 'Pantera de Minas', apelido adquirido por ocasião de seu namoro com o colunista Ibrahim Sued.

Em primeiro julgamento que teve repercussão nacional dada a grande cobertura da TV Globo, foi inocentado sob o argumento da 'defesa da honra'157, pois teria sido traído [foi condenado a dois anos com sursis no primeiro julgamento, em 1979, baseado em uma tese de legítima defesa da honra do criminalista Evandro Lins e Silva]. A reação popular resultou em cancelamento desse julgamento e numa segunda ocasião, foi condenado por homicídio

\footnotetext{
${ }^{157}$ Em 8 de março de 2005, por ocasião do Dia Internacional da Mulher, o presidente Lula sancionou lei aprovada no Congresso que altera o Código Penal, revogando o adultério do capítulo dos crimes contra o casamento. Foi com base no crime de adultério previsto no Código Penal, em vigor desde 1940, que durante décadas o homem que matava uma mulher acabava se livrando da cadeia. Disponível em $<$ www.violenciamulher. org.br>. Acesso: 5 mar 2011.
} 
[em novembro de 1981, cinco anos após o crime, foi sentenciado a 15 anos de prisão, cumpriu três anos e meio e depois passou para o regime semi-aberto, sendo solto em 1987 em liberdade condicional]. Refutando veementemente a frase muito difundida na mídia que dizia que 'ele matou por amor', em 2006, lançou o livro 'Mea Culpa', no qual faz um relato de aproximadamente dez anos de sua vida e a motivação pela qual matou Ângela Diniz. ${ }^{158}$

Há que se reconhecer que, primeiramente, foi a força do movimento “quem ama não mata”, organizado por militantes feministas, que desencadeou os protestos populares pela anulação do primeiro julgamento e uma mudança na cobertura da mídia. O slogan do movimento feminista tornou-se, mais tarde, o título de uma minissérie de televisão.

Segundo Eva Alterman Blay $\left(2003\right.$, p.3) ${ }^{159}$, feminista, professora de sociologia da USP e coordenadora científica do Núcleo de Estudos da Mulher e Relações Sociais de Gênero, da mesma universidade,

[...] acostumado à subserviência conservadora, Lins e Silva, defensor de Doca, revelou seu espanto ante a extraordinária pressão popular que acompanhou o julgamento. 0 caso teve enorme repercussão não só no Brasil, mas também no exterior, havendo 'publicidade nunca vista' sobre este caso, reclamou Lins e Silva (1991, p. 295). Grande controvérsia ocupou a imprensa (Blay, 2003) acirrando-se a polêmica contra os direitos humanos das mulheres. Os jornalistas Paulo Francis e Tristão de Ataíde mostraram-se indignados contra as feministas e suas manifestações públicas que, segundo eles, pré-condenaram o réu; Lins e Silva (1991, p. 295) irritou-se com a repercussão que transformou uma 'briga entre amantes em acontecimento nacional'. Referiu-se ao 'incidente' como se a vítima estivesse viva. [...] 0 modelo paradigmático da didática de defesa dos assassinos 'por amor' encontra-se no livro de Evandro Lins e Silva A defesa tem a palavra (1991). Nele, o jurista ensina os jovens advogados a defender um assassino mesmo que confesso, e toma

\footnotetext{
${ }^{158}$ Disponível em: $<$ http://pt.wikipedia.org/wiki/Doca_Street>. Acesso: 22 mai 2011.

${ }^{159}$ BLAY, E. A. Violência contra a mulher e politicas públicas - Estudos Avançados - Print version ISSN 0103-4014. Estud. av. vol.17. no.49. SP. set-dez/2003. Disponível em <http://www.scielo.br /scielo.php?script=Sci arttext\&pid=S0103-40142003000300006) $>$ Acesso: 20 set 2011.
} 
como modelo a defesa que ele próprio fizera de Doca Street.

Um trecho de uma das matérias publicadas na mídia, que foi destacado no texto de Eva Blay (2003, PC. 3), vale a pena ser aqui reproduzido, em função de ser de autoria de um conceituado jornalista, Carlos Heitor Cony, atualmente, um dos editorialistas do jornal Folha de S. Paulo. Na época, em matéria na Revista Fatos e Fotos - Gente, ele revela um pensamento permeado pelo machismo, o que contribui para perpetuar os estereótipos que reforçam a construção social de gênero:

[...] eu vi o corpo da moça estendido no mármore da delegacia de Cabo Frio. Parecia ao mesmo tempo uma criança e boneca enorme quebrada... Mas desde o momento em que vi o seu cadáver tive imensa pena, não dela, boneca quebrada, mas de seu assassino, que aquele instante eu não sabia quem era." (grifo meu). [Revista Fatos e Fotos - Gente]

De maneira geral, pode-se dizer que existe, no mínimo, certa cautela por parte das feministas com relação à mídia, da mesma forma em que há demonstrações de que os meios de comunicação ainda têm uma visão estigmatizada do movimento, provavelmente, por sofrerem influência de uma das correntes do feminismo, o radical. Como já dito por Heleieth Saffiotti (1987, p. 115-116), uma corrente "tão sexista quanto o machismo"160. Os profissionais da mídia necessitam, portanto, ampliar horizontes no sentido de considerar a existência de feminismos - no plural.

De acordo com Cristina Costa ${ }^{161}$ (2010), o mito da caverna de Platão é um bom exemplo para ilustrar como as pessoas encaram a mídia:

[...] Havia pessoas acorrentadas numa caverna, que viam sombras e achavam que era a realidade do que ocorria lá fora. Uma pessoa

\footnotetext{
${ }^{160}$ Ibidem. p. $115 / 6$

161 Aula ministrada em 6/4/2010, da disciplina Fundamentos da Comunicação e Expressão Humanas, na USP/ECA, coordenada por ela.
} 
saiu da caverna, viu que eram sombras, voltou e contou que eram apenas imagens, que não existiam pessoas. Elas não acreditaram! Platão queria mostrar que a única maneira de conhecer a realidade era a razão, o raciocínio, o conhecimento, pois é muito fácil enganar os sentidos. É assim que as pessoas se colocam com relação aos meios de comunicação de massa, que foram criando outras maneiras de representar a realidade, fez com que aumentasse o medo de estar frente a uma realidade criada com o objetivo de nos enganar. Imagens são manipuladas para dar falsas impressões do mundo. A Escola de Frankfurt desenvolveu esta teoria (na primeira metade do século $X X$ ), na época do desenvolvimento do rádio, utilizado por Hitler. Adorno, Marcuse, Benjamin e outros pensadores começaram a alertar o mundo sobre o poder de manipulação dos meios de comunicação de massa. Diziam que não se sabia o que estava por trás da cultura visual, sonora, como forma de manipulação dos sentidos, da cultura e do gosto. Os frankfurtianos pecaram ao pensar que todo público é completamente passivo. Barbero, Canclini e Orozco são nomes latinoamericanos importantes no sentido de desenvolver uma corrente de pensamento que analisa a comunicação do ponto de vista da cultura. Paulo Freire também estava nessa corrente de pensar que é possível desenvolver um pensamento crítico, adotando uma metodologia de trabalho. Todos trabalharam na contramão da teoria da recepção, voltando-se para a educomunicação.

Apesar da resistência dos movimentos sociais em incidir na mídia, como instrumento imprescindível e inevitável de avanço em suas propostas de cidadania ativa, há que se ponderar tal comportamento. No caso das mulheres, na era da informação e comunicação, há ainda o componente de gênero relacionado ao receio de enfrentar assuntos tecnológicos, o que, certamente, vai influenciar nas limitações do potencial de transformação. Além do mais, sem o domínio, pelo menos básico, do conteúdo tecnológico - responsável pelo novo cenário -, fica difícil alcançar a amplitude da visão política, econômica, social e cultural necessária para a reorientação da proposta de comunicação a distância que requer a leitura crítica e mecanismos de atuação na mídia, com um entendimento articulado de toda a complexidade envolvida. Como, 
apropriadamente, instiga Regina Festa (2001, p. 106) ${ }^{162}$,

[...] Onde está, portanto, o coração do problema, sob a ótica do movimento de mulheres, em relação aos impactos da sociedade da informação e do planeta-mídia? Em primeiro lugar, pode-se constatar que o movimento de mulheres, via de regra, organizouse paralelamente à implantação dos aparatos mediáticos, embora tenha influenciado e sofrido influência dos mesmos. Foram revoluções interdependentes, porém, de trajetórias singulares. Por parte das mulheres, os desafios para a constituição de direitos e cidadania excluíram das prioridades a análise das contradições culturais e ideológicas nas esferas públicas. Permanece, assim, um certo desconhecimento a respeito dos modos de operar e funcionar dos sistemas de produção e distribuição mediáticos e de expansão da informação e da comunicação. Com isso, operou uma certa visão instrumental do sistema, que atribuiu à mídia o papel de difusionismo informacional, funcionando low profile e em competição com a estrutura comercial e patriarcal do próprio sistema.

Fica muito nítido que a democratização das relações entre homens e mulheres passa, necessariamente, pela esfera pública e privada. A constatação de que quem está na esfera pública tem necessidades privadas não é menos verdadeira que seu oposto. Para se transformar essa crise em oportunidade, fazse necessário uma união de forças. Como ressalta Bourdieu (1999, p. 139) ${ }^{163}$,

[...] só uma ação política que leve realmente em conta todos os efeitos de dominação que se exercem através da cumplicidade objetiva entre as estruturas incorporadas (tanto entre as mulheres quanto entre os homens) e as estruturas de grandes instituições em que se realizam e se reproduzem não só a ordem masculina, mas também toda a ordem social [...] poderá, a longo prazo, sem dúvida, e trabalhando com as contradições inerentes aos diferentes mecanismos ou instituições referidas, contribuir

\footnotetext{
${ }^{162}$ FESTA, R. Notas para um novo milênio: questões de gênero e sistemas de comunicação e informação. In: Perspectivas de gênero - debates e questões para as Ongs. Recife. GT Gênero - Plataforma de contrapartes Novib / SOS Corpo. 2001. p.106

${ }^{163}$ BOURDIEU, P. A dominação masculina. Ed. Bertrand. Brasil. 1999. p. 139
} 
para o desaparecimento progressivo da dominação masculina.

Provavelmente, ainda sob o impacto da Conferência de Beijing ${ }^{164}$ e dos desafios midiáticos lá encarados, duas organizações feministas do Brasil - Centro de Estudos e Assessoria (Cfêmea) e Rede Nacional Feminista de Saúde e Direitos Reprodutivos -, em julho de 1997, juntaram-se a jornalistas de renome da chamada grande imprensa para organizar o seminário Mulher e Mídia - uma pauta desigual? Segundo palavras de Aureliano Biancarelli, na época atuando no jornal Folha de S. Paulo, na apresentação da publicação de mesmo nome,

[...] o seminário revelou para nós, jornalistas, que as feministas são preciosas fontes de boas matérias. E convenceu as mulheres - acredito eu - que os jornalistas são mais sensíveis à importância da notícia do que aos rótulos que são colocados aos grupos. [...] Uma pérola de ensinamento que deveria acudir a memória de informantes e repórteres: Tenha sempre presente que a relação é de troca. Os movimentos de mulheres querem colocar suas informações e opiniões. A mídia quer notícia atraente".

A análise de Biancarelli, depois de passada mais de uma década, ainda se coloca como uma utopia. Por isso, ainda continuam atuais as perguntas e respostas enfatizadas por Fernando Pacheco Jordão - então jornalista atuante em jornais, revistas, rádio e televisão - na contracapa da mesma publicação:

Perguntam de um lado da mesa: A mídia tem preconceito contra a mulher? Nas redações, feminismo virou palavrão? Por que não

164 Em 1995, representantes de 184 governos e mulheres de quase 2.500 organizações não-governamentais
reuniram-se em Beijing na Quarta Conferência Mundial sobre a Mulher. Em conjunto, chegaram a um acordo
que reconheceu que investir na saúde e direitos da mulher é a chave para solucionar os desafios globais.
Fonte: $\quad$ International $\quad$ Women's $\quad$ Health $\quad$ Coalition. $\quad$ Disponível
<http://www.iwhc.org/index.php?option=com content\&task=view\&id=2967\&Itemid=323>. Acesso: 22 mai
2011. O capítulo J - A Mulher e os Meios de Comunicação de Massa, da Plataforma de Ação de Pequim
estabelece como objetivos estratégicos: 1.1 . Aumentar a participação e o acesso da mulher na expressão de
suas ideias e nas tomadas de decisões nos meios de comunicação de massa e por seu intermédio, assim como
às novas tecnologias de comunicação. 1.2 . Promover uma imagem equilibrada e não-estereotipada da mulher
nos meios de comunicação. Disponível em: http://www.patriciagalvao.org.br/t3.htm. Acesso em: $10 \mathrm{Jan} 2012$. 
publicam o material que a gente manda? Só escândalo tem espaço no jornal?

Respondem de outro: Por que não nos trazem boas histórias e bons personagens, em vez de teses e estatísticas? Quem pode ser a porta-voz? Quem eu procuro no sufoco do fechamento? Vocês sabem como funciona uma redação?

Não há dúvidas de que o enfrentamento da cultura machista e patriarcal requer "políticas públicas transversais que atuem modificando a discriminação e a incompreensão de que os Direitos das Mulheres são Direitos Humanos. Modificar a cultura da subordinação de gênero requer uma ação conjugada" (BLAY, $2003)^{165}$. Os mecanismos de conjugação de esforços para uma atuação voltada para o feminismo e a comunicação incluem a conexão entre a mídia, a academia e as organizações não-governamentais. Por isso, esta pesquisa de doutorado tem a pretensão de oferecer uma contribuição de relevância social, a partir das novas narrativas propiciadas pelas mídias digitais e da consequente alteração nas dinâmicas de constituição dos modos de representação da mulher. Esse é o alicerce que pode levar a uma ação efetiva de comunicação a distancia com o objetivo último de contribuir para o avanço do processo de harmonização das relações sociais de gênero - fermento básico para a democracia em seu sentido amplo.

\footnotetext{
${ }^{165}$ BLAY, E. A. Violência contra a mulher e políticas públicas - Estudos Avançados - Print version ISSN 0103-4014. Estud. av. vol.17. no.49. SP. set-dez/2003). Disponível em <http://www.scielo.br/ scielo.php?script $=$ Sci arttext\&pid $=$ S0103-40142003000300006 $>$. Acesso: 20 set 2011.
} 
As possibilidades da era digital 
Para a maioria das mulheres do mundo, a Sociedade da Informação proporciona um espaço sem precedentes para afirmar sua cidadania e para renegociar suas relações sociais. Anita Gurumurthy 


\subsection{O pessoal é político: narrativas feministas e sociedade em rede redefinem o conceito de democracia}

As novas dinâmicas comunicacionais que submergem da era digital, consolidando nas práticas cotidianas uma profusão de formas de aprendizado e de expressão pessoal e interpessoal, agregam-se de forma potencializadora às revolucionárias narrativas feministas implementadas logo após a segunda metade do século passado. Como resultado, encontra-se a inexorável oportunidade de avanço da luta pela equidade das relações sociais de gênero, por meio de uma estratégia de comunicação a distância, para que se vislumbre uma reformulação da agenda feminista, visando à consolidação de formas mais efetivas de intervenção política e de atuação nas práticas pela equidade de gênero.

“Em briga de marido e mulher, não se deve meter a colher" é um ditado popular cuja utilização corriqueira persiste em existir, retratando exatamente o oposto da definição de feministas inglesas, no início dos anos 1970, de que "o pessoal é político". Como já descrito, foi quando se deu a grande arrancada da luta pela equidade de gênero em todo o mundo. Ao pautar na agenda política mundial a necessidade de harmonização das relações sociais de gênero para o avanço dos processos democráticos da civilização, essas feministas pioneiras alicerçaram uma nova caminhada rumo à desconstrução social dos âmbitos privado e público, marcados por séculos de patriarcado.

Saffioti (1997, p. 50) ${ }^{166}$ traz uma elucidação sobre o termo patriarcado, enfatizando que,

[...] no seio da família, a dominação masculina pode ser observada em praticamente todas as atitudes. Ainda que a mulher trabalhe fora de casa em troca de um salário, cabe-lhe realizar todas as tarefas domésticas. Como, de acordo com o modelo, os afazeres domésticos são considerados 'coisas de mulher', o homem raramente se dispõe a colaborar para tornar menos dura a vida de sua companheira. [...] Isto posto, pode-se concluir que o

${ }^{166}$ Ibidem. p. 50 
patriarcado não se resume a um sistema de dominação, modelado pela ideologia machista. Mais do que isto, ele é também um sistema de exploração. Enquanto a dominação pode, para efeito de análise, ser situada essencialmente nos campos político e ideológico, a exploração diz respeito diretamente ao terreno econômico."

O processo de reconstrução da identidade feminina começou já no século $\mathrm{XVI}$, conforme demonstra o resgate histórico feito por feministas: em 1405, Christine de Pisan, viúva e mãe de três filhos, escreve o livro "La Cité des Dames", sendo considerada pelas feministas como a primeira mulher a protestar contra o preconceito e discriminação ${ }^{167}$. Mulheres foram degoladas, sutiãs foram queimados em praça pública, para que o tema das relações sociais de gênero ganhasse importância e fosse pautado no mundo. E com o início da chamada sociedade em rede, mostra-se possível a reconstrução da identidade feminina, afrontando os alicerces da estrutura patriarcal na qual todas as sociedades se debruçam.

Ao se aprofundar na constatação do fim do patriarcado, Castells (1999, p. $169-170)^{168}$ ressalta que

[...] o patriarcalismo [patriarcado] é uma das estruturas sobre as quais se assentam todas as sociedades contemporâneas. Caracteriza-se pela autoridade, imposta institucionalmente, do homem sobre a mulher e filhos no âmbito familiar. Para que essa autoridade possa ser exercida, é necessário que o patriarcalismo [patriarcado] permeie toda a organização da sociedade, da produção e do consumo à política, à legislação e à cultura. Os relacionamentos interpessoais e, consequentemente, a personalidade, também são marcados pela dominação e violência que têm sua origem na cultura e instituições do patriarcalismo [patriarcado]. [...] A família patriarcal, base fundamental do patriarcalismo [patriarcado], vem sendo contestada neste fim de milênio pelos processos, inseparáveis, de transformação do

\footnotetext{
${ }^{167}$ Disponível em: <www.agende.org.br> $>$. Acesso: 10 mai 2011

${ }^{168}$ Ibidem. p.169-170
} 
trabalho feminino e da conscientização da mulher. As forças propulsoras desses processos são o crescimento de uma economia informacional global, mudanças tecnológicas no processo de reprodução da espécie e o impulso poderoso promovido pelas lutas da mulher e por um movimento feminista multifacetado, três tendências observadas a partir do final da década de 60 .

\subsubsection{Uma nova narrativa para o público e o privado}

Os movimentos sociais feministas e de identidade sexual contribuíram para levar ao desordenamento do padrão de família tradicional. Na Era da Informação e da Comunicação, essa identidade, que vem sendo reconstruída, depara-se com movimentos de resistência representados por fundamentalismos religiosos e nacionalismos, os quais temem nada mais nada menos do que o desmoronamento da família patriarcal (que é sempre heterossexual), em um mundo que está fora do controle. Um bom exemplo dessas transformações é dado pelo professor Barbero $^{169}$, durante a aula do dia 16/09/2008, na ECA/USP:

[...] Uma companheira de universidade ganhou uma bolsa de doutorado na Inglaterra, país em que não há a categoria de acompanhante para o marido. Somente para as mulheres existe essa categoria, quer dizer, elas podem acompanhar o marido que vai estudar. A única maneira legal de levá-lo, foi como babysitter.

Barbero (2006, p. 4-6) ${ }^{170}$ constata que "nada nos preparou para conviver com a incerteza, nem o Marxismo, nem o Cristianismo". Faz um paralelo à época de mudanças profundas no planeta em função das novas tecnologias da informação e comunicação, incluindo o advento da internet, "cuja única

\footnotetext{
169 A convite do Programa de Pós-Graduação em Ciências da Comunicação (PPGCom), o professor JesúsMartin Barbero ministrou, no período de 15 a 19/9/2008, nas dependências da ECA/USP, o curso "Novas Sensibilidades: entre Urbanias e Cidadanias, do qual esta pesquisadora participou.

${ }^{170}$ MARTIN-BARBERO, J. Entre urbanias e cidadanias. In. Cartografias Culturais da sensibilidade e da tecnicidade (apostila). Bogotá: Junho/2006. p. 4-6
} 
comparação equivalente que se pode fazer é ao invento da escrita, com mudanças proporcionais à insegurança que sentimos em todos os sentidos”. Ele elabora as seguintes formas de experiência espacial:

\section{$\rightarrow$ espaço HABITADO ou a "mátria"}

É o espaço primeiro dos corpos e do território. [...] o ser humano não tem um corpo, seu corpo é a forma primitiva de seu habitar no mundo, aquela relação com o mundo que é constitutiva de sua peculiar espacialidade: feita da 'carne do mundo'.

$\rightarrow 0$ espaço IMAGINADO ou a "pátria"

Esta espacialidade provém da reflexão de B. Anderson sobre a 'comunidade imaginada', em que se constitui a nação-estado quando a sociedade moderna começa a substituir a comunidade orgânica pré-moderna.

\section{$\rightarrow 0$ espaço PRODUZIDO, ou a "frátria"}

Os espaços habitados, os territórios, entraram muito cedo em conexão uns com os outros, em uma batalha de guerras e de interdependências que deram lugar a outra espacialidade, a do espaço produzido.

\section{$\rightarrow$ espaço PRATICADO: entre urbanias e cidadanias}

0 primeiro a falar dessa espacialidade foi W. Benjamim, ao observar que a cidade moderna se forma não somente pelas novas construções - como os bulevares e as passagens - mas sim pelos passeios das grandes avenidas e pela nova arte que é o cinema.

Espaço e tempo são estruturas de nossa percepção dos sentidos. Um novo tempo, com novas formas de ver, sentir e pensar, em que as identidades se revitalizam por meio de novas espacialidades, reconstruindo, em termos de relações sociais de gênero, os laços sociais e a convivência em âmbito local, nacional e mundial, por meio do sentido que se configura com a narração. Apesar dessa fábrica de presente - sem referência ao passado e sem projeção do futuro - (um “presente altista”, como denomina Barbero), há possibilidades de avanço no processo de redefinição do que significa democracia, a partir do feminismo e da sociedade em rede.

Como bem salienta Barbero, durante o curso na ECA/USP, "é possível 
aumentar as brechas para a construção de relatos. A esperança se dá através dos desesperados. Como nunca se viu tantos desesperados, hoje, podemos ter esperança!” A esperança de que os espaços privado e público sejam compartilhados, com equidade, por homens e mulheres. É esta a utopia que move esta pesquisa de doutorado, cuja concretização submerge com a perspectiva da comunicação a distancia alicerçada na revolução da internet, já que as novas mídias reconfiguram a representação dos papeis da mulher no mundo, por meio de novas narrativas, isto, é outras formas de expressão pessoal e interpessoal.

\subsection{A pesquisa-ação}

Apesar de a pesquisa-ação já ter sido amplamente adotada pelo movimento de mulheres, desde a década de 70, considera-se um desafio sua aplicação em uma investigação com os recortes explicados. Até mesmo, de forma geral, o modelo metodológico para pesquisa-ação em comunicação, sob a perspectiva qualitativa, dada a sua peculiaridade, vem sendo questionada pelo universo científico, levando em conta a concepção, a organização e os objetivos alcançáveis. Além disso, o/a pesquisador/a precisa adotar uma postura de vigília permanente para não incorrer, por um lado, no risco das generalizações do saber popular, e, por outro, nas generalizações teóricas. Segundo Thiollent (1998, p. 25) $)^{171}$,

[...] a pesquisa-ação não é considerada como metodologia: tratase de um método, ou de uma estratégia de pesquisa agregando vários métodos ou técnicas de pesquisa social, com os quais se estabelece uma estrutura coletiva, participativa e ativa ao nível da captação de informação. A metodologia das ciências sociais considera a pesquisa-ação como qualquer outro método. Isto quer dizer que ela a toma como objeto para analisar suas qualidades, potencialidades, limitações e distorções.

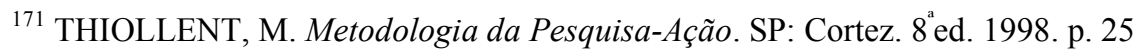


Maria Immacolata V. Lopes $\left(1997\right.$, p. 13) ${ }^{172}$, ao alertar para a necessidade de um maior número de investigações que reflitam a ciência que está se constituindo, enfatiza

[...] a necessidade urgente de se refletir sobre a ciência que se está fazendo em Comunicação no país. A legitimação da prática da pesquisa, que é essencialmente uma prática metodológica. A preocupação com a teoria (que é um dos níveis de qualquer discurso científico) na pesquisa tem relegado para segundo plano as questões de metodologia, tanto em termos de seu estudo (Metodologia enquanto disciplina), como em termos de sua aplicação (Metodologia enquanto prática). Esse desequilíbrio entre o conteúdo teórico e a forma como ele é constituído parece ser um traço específico da pesquisa em Comunicação no país e contribui para reforçar um dualismo teoria-metodologia fundamentalmente perigoso para o reconhecimento científico do campo da Comunicação.

Em outro trecho de sua obra, abordando a especificidade da pesquisaação, Thiollent (1998, p.14) ${ }^{173}$ elucida:

[...] A pesquisa-ação é um tipo de pesquisa social com base empírica que é concebida e realizada em estreita associação com uma ação ou com a resolução de um problema coletivo e no qual os pesquisadores e os participantes representativos da situação ou do problema estão envolvidos de modo cooperativo ou participativo.

Com o domínio dos conceitos existentes sobre este modelo metodológico na área de comunicação, também foi possível formular as premissas abaixo, com a consciência de que se traduzem em suportes para guiar a pesquisa. Com esse conjunto de premissas, "não se chega a propor uma verificação objetiva, neutra,

\footnotetext{
${ }^{172}$ LOPES, M. I. V. Pesquisa em Comunicação. SP: Loyola. $3^{\mathrm{a}}$ ed. 1997. p. 13

${ }^{173}$ Ibidem. p. 14
} 
mas se consegue um consenso a partir do compartilhar do conhecimento" (OROZCO, 1997, p.45) $)^{174}$.

- As novas mídias são uma revolução tecnológica que traz consigo uma revolução do aprendizado e das relações pessoais e interpessoais, reconfigurando a representação dos papéis da mulher no mundo, por meio de novas narrativas.

- As mídias digitais reconfiguram positivamente a representação da mulher, propiciando a potencialização do feminismo, por meio da comunicação a distância.

- As mídias digitais podem ser utilizadas como ferramenta de transformação do espaço privado, no que concerne à questão da violência doméstica, partindo-se da premissa que o privado é público e o público é privado, além de alavancar a luta pela equidade de gênero, graças às novas dinâmicas comunicacionais que promovem mudança de mentalidades.

- A violência doméstica continua a ser silenciada sob o jargão em briga de marido e mulher, não se mete a colher. Romper o silêncio é o primeiro e grande passo para que a mulher rompa o ciclo da violência. Para tanto, é importante que existam espaços online onde possam se sentir a salvo do assédio, desfrutar a liberdade de expressão e a privacidade da comunicação, assim como estar protegidas da espionagem eletrônica.

- As barreiras culturais e de gênero impedem que as mulheres participem plenamente do mundo da tecnologia - incorrendo no que se denomina tecnofobia. Os programas de aprendizagem devem estar desenhados para as mulheres como usuárias, técnicas, formuladoras de políticas e agentes de transformação.

\footnotetext{
${ }^{174}$ OROZCO, G. La investigación en comunicación desde la perspectiva cualitativa. Guadalajara/México. Facultad de Periodismo y Comunicación Social, Universidade de la Plata \& IMDEC (Instituto Mexicano para el Desarrollo Comunitario, A.C.). $2^{\text {a }}$ ed. 1997. p.45
} 
- O ciberespaço pode ser utilizado para preservar a diversidade e proporcionar uma plataforma na qual possa ser escutada uma multidão de vozes, garantindo o pluralismo de ideias e opiniões, o compartilhamento e intercâmbios culturais.

- [...] Para que se manifestem fenômenos de utilização da rede nas mudanças de consciência e informação das pessoas, é preciso haver antes de mais nada rede em condições e que também exista interesse das pessoas num sistema político. (CASTELLS, 2010, p. 5) ${ }^{175}$

- [...] 0 poder sempre esteve baseado no controle e, às vezes, na manipulação da informação. O grau de autonomia das pessoas para se comunicar, informar e organizar suas próprias redes de sociabilidade é muito mais potente com a internet. Ela é a construção da autonomia da sociedade civil. ${ }^{176}$ (idem)

Obviamente, a estratégia metodológica adotada está diretamente vinculada ao envolvimento participativo da pesquisadora, tendo em vista sua inserção social - como já dito, é agente educadora da ONG Rede Mulher de Educação há quinze anos.

As conclusões - que, de acordo com o processo dialético, não são válidas para sempre - serão expostas mais à frente com um resumo dos resultados alcançados nos planos teóricos, metodológicos, temático e prático.

\footnotetext{
${ }^{175}$ Resposta de Manuel Castells, a uma das perguntas formuladas por Alec Duarte, na entrevista intitulada Se um país não quer mudar, não é a rede que irá mudá-lo. Folha de S.Paulo. 21/09/10. p. especial 5 (pergunta: "Hoje quase não há discussão política na internet brasileira, apenas torcidas trocando provocações. E essas discussões não extrapolam a própria rede. $O$ fato de a web não possuir no país uma penetração grande afeta diretamente a repercussão fora dela?")

${ }^{176}$ Idem (pergunta: "Por que a internet amedronta o poder político?”)
} 


\subsubsection{O objeto de Estudo e a Justificativa}

Na era digital, a comunicação a distância mostra-se como um caminho de reformulação da agenda feminista, balizada por novas estratégias de intervenção política e de atuação, levando em conta outras dinâmicas e a revolução das formas de expressão pessoal e interpessoal.

O objeto de estudo está retratado na afirmação acima, para firmar como o movimento feminista tem utilizado a comunicação tradicional e como pode alterar essa relação com as mídias digitais, já que as formas de representação da mulher podem ganhar outras dinâmicas, propiciadas por uma nova cultura comunicacional. Essa revolução se materializa nas formas de produção, interatividade - comunicação instantânea e processos colaborativos -, compartilhamento e amigabilidade, criando novas relações de imaginários, o que possibilita a promoção de ações de mudança de mentalidades.

Assim sendo, a pergunta acima permeia toda a trajetória desta pesquisaação - uma investigação dialógica, a partir da perspectiva qualitativa - junto com um grupo mulheres. Cabe explicar melhor o sentido em que está sendo utilizada a expressão dialógica, embasada no pensamento de Paulo Freire (1983, p. 78$)^{177}$ :

[...] a educação problematizadora - situação gnosiológica afirma a dialogicidade e se faz dialógica. Não seria possível à educação problematizadora [...] realizar-se como prática da liberdade, sem superar a contradição entre o educador e os educandos. Como também não the seria possível fazê-lo fora do diálogo. [...] Desta maneira, o educador já não é o que apenas educa, mas o que, enquanto educa, é educado, em diálogo com o educando que, ao ser educado, também educa. Ambos, assim, se tornam sujeitos do processo em que crescem juntos.

Outra contribuição que complementa o entendimento do termo é dada por

${ }^{177}$ FREIRE, P. Pedagogia do Oprimido. SP: Paz e Terra. $15^{\mathrm{a}}$ ed. 1983. p. 78 
Citelli (1999, p. 55) ${ }^{178}$ :

[...] No movimento dialógico, a produção do sentido não surge, contudo, 'aqui' apenas na capacidade denominadora (nomem) da linguagem. Para significar, o 'aqui' requer contratos comunicacionais que se alimentam necessariamente, além dos aspectos normativos e expressivos, dos cruzamentos históricos postos nos espaços sociais.

O objetivo central da pesquisa traduz-se na implementação do uso da internet - mais especificamente das redes sociais - para o avanço da luta contra a violência às mulheres, no âmbito doméstico, considerando-se essa realidade como a mais grave expressão da assimétrica construção social de gênero.

A pesquisa-ação abarcou atividades de capacitação realizadas em 2010, no marco do projeto Fortalecimento das Mulheres no uso estratégico das tecnologias da informação e comunicação (TIC) para erradicar a violência contra mulheres e adolescentes, que foi desenvolvido em diversos países, contando com a coordenação voluntária desta pesquisadora no Brasil, por meio da ONG Rede Mulher de Educação. As atividades do projeto foram realizadas concomitantemente em 12 países da América Latina, Ásia e África, no período de 06/2009 a 06/2011. Recebeu apoio do Fundo “Objetivos de Desenvolvimento do Milênio (ODM3)", da Holanda, através da Associação para o Progresso das Comunicações / Programa de Apoio às Redes de Mulheres (APC/ PARM) ${ }^{179}$. Buscou contribuir para criar uma comunidade global de mulheres e adolescentes que estejam se apropriando das ferramentas de TIC, utilizando-as para alterar o que o Projeto do Milênio batizou de epidemia global de violência. Procurou encontrar soluções mais realistas e sustentáveis a essa problemática, com o empoderamento das mulheres e adolescentes mediante capacitação e conscientização.

\footnotetext{
${ }^{178}$ Ibidem. p. 55

179 A doutoranda está interligada a essa rede desde o ano 2000, usufruindo de processos de capacitação internacionais, articulações e coordenação de trabalhos.
} 
A Rede Mulher de Educação é uma entidade sem fins lucrativos fundada em 1980, cujo trabalho está focado no empoderamento ${ }^{180}$ das mulheres por meio da formação de lideranças para ocupação dos diversos espaços, visando à conquista de uma sociedade com equidade de gênero. A Rede Mulher, desde o ano 2000, tem um de seus três programas intitulado Educomunicação, graças aos conhecimentos adquiridos por esta pesquisadora junto à Escola de Comunicações e Artes / Núcleo de Comunicação e Educação (ECA/NCE), onde concluiu o Curso de Gestão da Comunicação, tendo, posteriormente, defendido a dissertação de mestrado Gênero e Educação para Intervenção nos Meios, também uma pesquisaação. A tese de doutorado é um prolongamento da teoria e prática acumuladas no transcorrer dos anos, considerando-se as necessidades específicas na temática da violência contra a mulher e a oportunidade de tornar a internet um instrumento estratégico e de transformação.

Novos desafios são colocados à prática do feminismo, não só em função da aceleração dos processos de implantação das TIC - que têm na internet seu maior advento - para uma população cada vez maior, como em virtude das barreiras culturais e de gênero que se tornam empecilhos para a plena participação feminina, que têm como consequência a "tecnofobia". Este termo, amplamente utilizado pelo movimento feminista para denominar o medo da tecnologia moderna, foi abordado em uma das oficinas de capacitação, para a conscientização e a transposição de barreiras pelas participantes, nas ocasiões em que ocorre uma naturalização dos papeis do tipo "coisas de homem versus coisas de mulher". Se por um lado navegar e aventurar-se na internet é mais fácil para os homens em função de comportamentos apreendidos desde a infância, há que se relevar a criatividade e vida em rede, duas características amplamente vivenciadas pelas mulheres.

\footnotetext{
${ }^{180} \mathrm{O}$ termo empoderamento estará sendo utilizado, apesar de ainda não ter sido dicionarizado. A tradução do termo em inglês - empowerment - torna-se corrente entre feministas, desde o início da década de 90, e tem o significado de um processo complexo de crescimento individual e de grupo em relação à autonomia e à solução de problemas. É a preparação para o exercício da cidadania em seu sentido mais amplo. É o desenvolvimento da auto-confiança e da percepção da capacidade em mudar relacionamentos. É o desenvolvimento da capacidade de enfrentar desafios e eliminar a mentalidade de vítima. (Relatório de Atividades da Rede Mulher. SP. 1998)
} 
Quando se afunilam os desafios das diversas consequências da iniquidade de gênero para a questão da violência doméstica, depara-se com a privacidade, a segurança e os direitos à internet como áreas de fundamental importância para o avanço da luta. As tecnologias, em todas as suas etapas, não são neutras em termos de gênero e diversidade: no desenho - criação, desenvolvimento e implementação -, no acesso e na utilização. Daí a necessidade de se influir em diferentes aspectos das TIC com lentes de gênero e diversidade, focando nos principais problemas, como também nas grandes oportunidades desencadeadas pelas mídias digitais, já que elas provocam um novo modo de ver, pensar e agir, com potencial favorável à harmonização das relações sociais de gênero. É por isso que esta tese endossa o convite de Levy (1996, p. 150) ${ }^{181}$ : “Benvindos [Bemvindos/as] à nova morada do gênero humano. Benvindos [Bem-vindos/as] aos caminhos do virtual!”.

\subsubsection{As etapas da experiência}

Existem peculiaridades na metodologia da pesquisa-ação, que fogem ao esquema tradicional. A estrutura a seguir tem a função de retratar os passos da nova estratégia adotada para avançar no percurso feminista.

As atividades previstas encontram-se abaixo relacionadas e, de acordo com a APC/PARM, têm o objetivo de promover a capacitação e a articulação no apoio à construção de uma rede local, nacional e internacional, para o enfrentamento da violência contra a mulher. Esse objetivo principal encontra-se destacado no projeto ODM3 (Objetivos de Desenvolvimento do Milênio), desenvolvido, concomitantemente, em doze países de diversos continentes, conforme já explicado. Para esta pesquisa-ação, somam-se outros desafios, conforme lista de premissas detalhada no início deste capítulo.

O modelo das oficinas centrou-se em momentos distintos, mas que foram

181 Ibidem. p. 150 
minuciosamente planejados para se entrelaçarem, incluindo-se métodos e técnicas complementares que levassem à efetiva abordagem do objeto de pesquisa. Posteriormente, com o distanciamento e o olhar crítico, esta pesquisadora mergulhou em outras reflexões científicas, para chegar a argumentos conclusivos sobre a possível efetividade e avanço de uma proposta de comunicação a distância, que priorize a ação política em prol da causa feminista coerente com demandas contemporâneas, fortemente caracterizadas pelas mídias digitais no cotidiano das pessoas.

Esta pesquisadora entende que o relato do conhecimento das ações elaboradas - por uma dinâmica que tem especificidades - deve ser fiel ao que foi produzido coletivamente:

\section{- Participantes}

Ao invés de optar pela ampla divulgação para a seleção das participantes, esta pesquisadora e as coordenadoras das demais entidades parceiras - Jacira Melo do Instituto Patrícia Galvão Comunicação e Mídia, e Nilza Iraci do Geledés Instituto da Mulher Negra - decidiram realizar uma seleção direcionada de lideranças efetivas ou potenciais que já estivessem atuando em organizações de base voltadas para a conexão entre TIC e relações sociais de gênero, mesmo que de forma não sistemática e estratégica. Esta decisão também levou em conta fatores como diversidade de raça/ etnia, de orientação sexual, geracional e de localização geográfica - esta última, considerando as limitações financeiras. Assim sendo, foram selecionadas 30 participantes, por indicação das oito entidades de base, que são as seguintes: Grupo de Mulheres Cidadania Feminina (Recife/PE), Centro das Mulheres do Cabo (Recife/PE), Coturno de Venus Associação Lésbica Feminista de Brasília (Brasília/DF), Nami Rede Feminista de Arte Urbana (Rio de Janeiro/RJ), Promotores Legais Populares do Movimento de Mulheres Negras (São Paulo/SP, bairro de São Matheus), União de Mulheres de São Paulo (São Paulo/SP), Sociedade Comunitária Ecológica Cultural Fala Negão / Fala Mulher da Zona Leste (São Paulo/SP) e Associação de Mulheres da Zona Leste (Amzol). A lista de participantes encontra-se no Anexo C. 


\section{- Local e Programa}

As oficinas de capacitação foram realizadas na sede de uma das organizações parceiras - Geledés Instituto da Mulher Negra (Rua Santa Isabel, 137, $4^{\circ}$ andar, São Paulo/SP) -, a qual oferecia as condições logísticas ideais, com duração de 16 horas ( $1^{\text {a }}$ oficina) e 14 horas ( $2^{\mathrm{a}}$ oficina). 0 consenso sobre 0 formato e o conteúdo das oficinas (ver programas também no Anexo C) ficou a cargo das coordenadoras já citadas, um trabalho de bastidores que é fundamental e merece visibilidade. Da mesma forma, ressalte-se o trabalho de secretaria do evento, com os inúmeros contatos com as participantes, a reserva de local para a realização da oficina, do transporte, do hotel, de restaurante, a montagem das pastas com material, a adoção de procedimentos de reembolso financeiro, etc. - a cargo de Walkíria Ferraz.

\section{- Material teórico}

Logo no início de cada oficina, foi entregue uma apostila editada por esta pesquisadora, contendo os objetivos e passos do projeto, material teórico ilustrado sobre a temática, além de publicações correlatas. Trata-se de uma produção que objetivava tanto auxiliar ao desenrolar da oficina, como subsidiar ao futuro processo de multiplicação.

\section{- Registro}

Foi planejada, antecipadamente, a utilização da técnica de registro escrito e de registro fotográfico - a cargo desta doutoranda. Ambos visaram tanto registrar a produção coletiva para devolução às participantes e às agências internacionais de cooperação, como obter detalhes para auxiliar na reflexão posterior ao término da experiência. Obviamente, os produtos multimídia criados pelas participantes tornaram-se registros online definitivos.

\section{- Discussões e}

\section{- Exposições teóricas}

São momentos fundamentais que se somam, visando ao compartilhar do conhecimento, para alicerçar o caminho que vai se delineando no sentido de se 
chegar a um consenso de compreensão.

As exposições teóricas foram realizadas por esta pesquisadora, além das seguintes palestrantes e monitoras: Cacau Freire (doutoranda da USP/ECA), Nilza Iraci (do Geledés Instituto da Mulher Negra), Jacira Melo e Ana Rosa Carrara (do Instituto Patrícia Galvão Comunicação e Mídia), Anna Frank (da União de Mulheres de São Paulo), Ana Célia Minuto de Campos (da Sociedade Comunitária Fala Negão, Fala Mulher) e Panmela Castro (da Anarkia Graffiteiras - Rede Nami).

- Recursos tecnológicos

O local em que foi realizada a oficina contava com laptops, internet banda-larga em rede, data-show e máquinas fotográficas digitais. Antecipadamente, foi solicitado às participantes que trouxessem aparelho celular e máquina fotográfica digital, quando disponível. Esses recursos foram utilizados tanto nas exposições das palestrantes e participantes, como nos momentos dos trabalhos em grupos.

\section{- Trabalhos em grupos}

Nas duas oficinas, houve trabalho em grupos para a criação e viabilização dos produtos digitais, tais como spots, pôsters, vídeos e blogs. Na primeira oficina, foi feita a divisão mesclando-se participantes de diferentes entidades para que, pelo menos uma integrante de cada uma delas, estivesse em cada uma das distintas produções e pudesse multiplicar o conhecimento adquirido em suas regiões. Na segunda oficina, optou-se pela formação de grupos com integrantes da mesma organização, já que a temática seria mais bem desenvolvida com um maior grau de entrosamento entre as participantes. Cada grupo definia uma sistematizadora do processo de produção, para apresentação em plenário.

- Consenso do saber e possibilidades de continuidade

Este momento representa a síntese da ponderação do conteúdo apresentado pelos grupos, das discussões e das contribuições teóricas, que vão justificar a possibilidade de se adotar um plano de ação para a continuidade e 
multiplicação do saber compartilhado.

\subsubsection{1 $1^{\text {a }}$ Oficina de capacitação: Intercâmbio Tecnológico Feminista - Internet e violência doméstica: fazendo e intervindo}

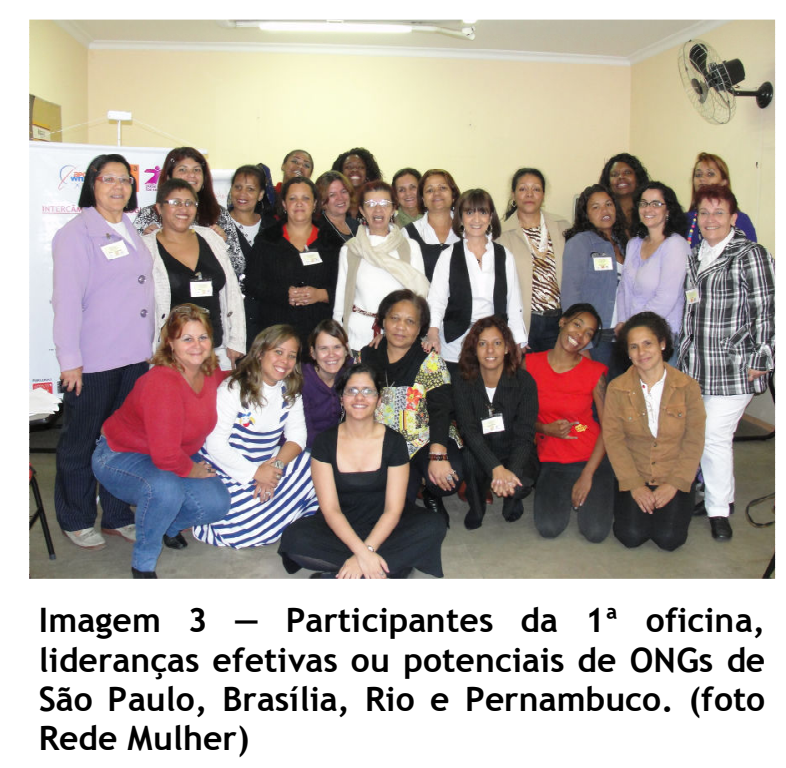

Realizada nos dias 14 e 15 de maio de 2010 (sexta-feira e sábado), na cidade de São Paulo, esta oficina contou com um programa minuciosamente preparado, incluindo teoria e prática, tendo a participação de 29 mulheres, das 30 escolhidas.

De forma estratégica, esta primeira oficina se ateve à criação de produtos digitais (blogs, pôsters, spots e vídeos) que utilizassem apenas as TIC elementares, isto é, aquelas acessíveis à maioria da população, como o telefone celular e a câmera fotográfica, junto com a internet, com a finalidade de enfrentar a violência doméstica. Era nítido o entusiasmo e alto nível de envolvimento de todas as participantes, tanto durante o aprofundamento teórico, quanto durante a criação dos produtos, os quais apresentaram um bom nível de qualidade, o que superou as expectativas das palestrantes e monitoras.

O início da oficina se deu com uma dinâmica coordenada por esta doutoranda, com base em preceitos da educação popular feminista. Trata-se de 
uma metodologia que

[...] tem por base a construção coletiva do conhecimento, levando em conta aspectos objetivos e subjetivos, pois se considera que a realidade é construída pelas pessoas tanto pela via da razão como pela via da emoção. É uma forma dialógica de educar - com base na realidade das pessoas participantes, com elas e não para elas. Assim, o conhecimento é gestado de forma coletiva, considerando-se a visão local, para inseri-la no contexto nacional, regional e global - e vice-versa. [...] As participantes são pessoas que se caracterizam por distintos sujeitos sociais, entretanto, agregados coletivamente por uma aura, uma atmosfera, um estado de espírito, em busca do objetivo comum de avançar na luta pela igualdade e equidade de gênero, formando um grupo social com sintonia de interesses. Considerase, portanto, a premissa de que esse grupo social é uma das fontes de mediação, que é potencializadora da transformação social por meio de um processo de construção coletiva do conhecimento, que oferece sustentação para a atuação política e envolvimento de novos agentes. ${ }^{182}$

A dinâmica agregou levantamento de expectativas e, para introduzir a temática de forma sensibilizadora, os aspectos negativos e positivos inerentes à utilização da internet, para posterior aprofundamento sobre as nuances que interconectam a temática das relações sociais de gênero e das TIC. Dentre os aspectos positivos, destacaram-se: fluxo ilimitado de informação e conhecimento, interatividade, possibilidades de produzir informação, comunicação global, mais informações sobre violência contra a mulher. Para os aspectos negativos, foram citados: utilização criminal, perigo à privacidade, inclusão de informações não confiáveis, pedofilia, assédio, exclusão digital, distanciamento nas relações pessoais. As expectativas revelaram otimismo por parte das participantes: aprendizado e interação; troca de conhecimento e informação; implementação da luta contra a violência à mulher utilizando-se novas ferramentas de forma estratégica. Na parte final de sua apresentação, esta

\footnotetext{
${ }^{182}$ PLOU, D.; VIEIRA, V. Mulher e Tecnologias: a virtualidade como espaço transformador das relações de gênero. São Paulo: Rede Mulher, 2007, p. 11-12.
} 
pesquisadora enfatizou a importância de se conscientizar sobre a influência exercida pelas TIC em todos os âmbitos da vida das pessoas, como um processo irreversível, isto é, um mundo com novas noções de tempo e espaço, com um novo modo de sentir, pensar e agir. Além disso, é fundamental ter com premissa que as TIC podem ser utilizadas tanto para exacerbar como para transformar as relações de poder desiguais e as discriminações. Daí a necessidade de se aproveitar os aspectos positivos do novo panorama que se configura, por meio da atualização e implementação de ações via comunicação a distância visando à cidadania e aos processos de transformação social.

Em uma tentativa de ponderar os aspectos negativos e positivos do ciberespaço, Levy (1996, p. 117-118) ${ }^{183}$ destaca como em um desabafo:

[...] Cessemos de diabolizar o virtual (como se fosse o contrário do real!). A escolha não é entre a nostalgia de um real datado e um virtual ameaçador ou excitante, mas entre diferentes concepções do virtual. A alternativa é simples. Ou o ciberespaço reproduzirá o mediático, o espetacular, o consumo de informação mercantil e a exclusão numa escala ainda mais gigantesca que hoje. Esta é, a grosso modo, a tendência natural das 'supervias da informação' ou da 'televisão interativa'. Ou acompanhamos as tendências mais positivas da evolução em curso e criamos um projeto de civilização centrado sobre os coletivos inteligentes: recriação do vínculo social mediante trocas de saber, reconhecimento, escuta e valorização das singularidades, democracia mais direta, mais participativa, enriquecimento das vidas individuais, invenção de formas novas de cooperação aberta para resolver os terríveis problemas que a humanidade deve enfrentar, disposição das infraestruturas informáticas e culturais da inteligência coletiva.

\footnotetext{
${ }^{183}$ Ibidem. p. $117-118$
} 


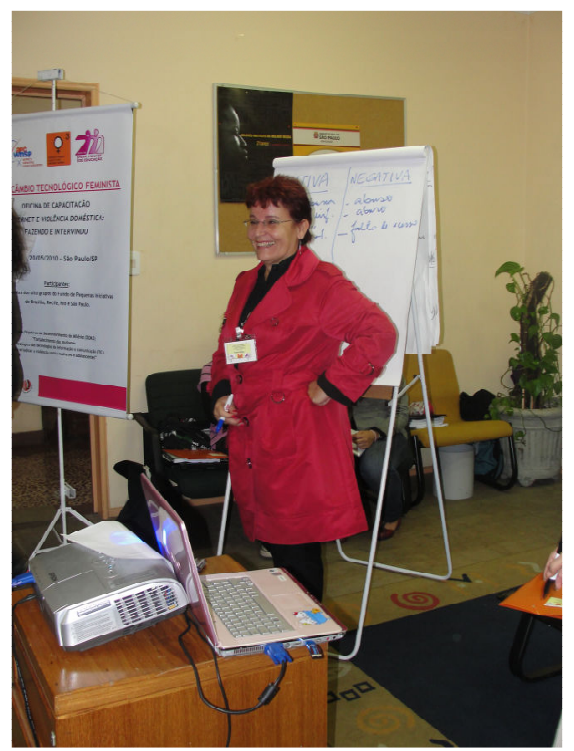

Imagem 4 - A doutoranda Vera Vieira iniciou a oficina com uma dinâmica de educação popular feminista, agregando a apresentação das participantes, o levantamento de expectativas, aspectos positivos e negativos da internet e o aprofundamento teórico. (foto: Walkíria Ferraz)

Em seguida, Cacau Freire discorreu sobre o mosaico de ferramentas existentes na internet, com foco nas redes sociais - blog, Twitter, Facebook, Orkut, MySpace e YouTube -, para a visibilidade da concretização das possibilidades de uso para a implementação da luta contra a violência às mulheres e adolescentes, além de enfatizar as potencialidades e os cuidados. 


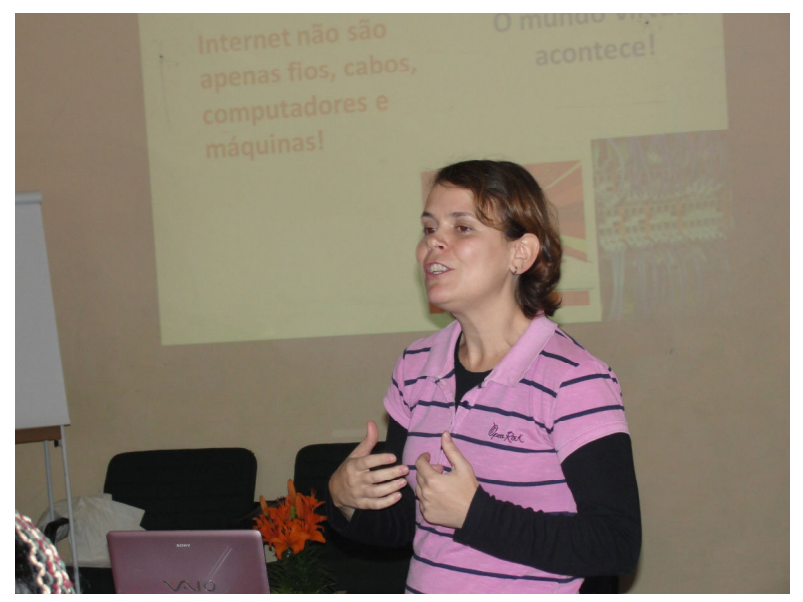

Imagem 5 - Cacau Freire (doutoranda da USP/ECA) abordou o fenômeno das redes sociais, indo dos aspectos técnicos ao potencial de avanço na luta contra a violência à mulher. (foto: Vera Vieira)

Houve uma revolução no jeito dos seres humanos se relacionarem. Para definir o que se passou a denominar comunidades virtuais, Santaella (2007, p. 413-414) ${ }^{184}$ sublinha se tratar de,

[...] grupos de pessoas globalmente conectadas com base em interesses e afinidades, em lugar de conexões acidentais ou geográficas.

Para Brenda Laurel (1990, p. 93), as comunidades virtuais são 'as novas e vibrantes aldeias de atividades dentro das culturas mais amplas do computador'. Elas são compostas de agrupamentos de pessoas que poderão ou não se encontrar face a face e trocam ideias através da mediação das redes de computador.

[...] Em suma, na cibermídia, outro nome para esse espaço público que está em construção (Bilwet, Adilkno e Filwis, 1999), as comunidades virtuais designam as novas espécies de associações fluidas e flexíveis de pessoas, ligadas através dos fios invisíveis das redes que se cruzam pelos quatro cantos do globo, permitindo que os usuários se organizem espontaneamente para 'discutir, para viver papeis, para exibir-se, para contar piadas, para procurar companhia ou apenas para olhar, como voyeur, os jogos sociais que acontecem nas redes' (Biocca, 1997, p. 219).

${ }^{184}$ SANTAELLA, L. Linguagens líquidas na era da mobilidade. São Paulo: Paulus, 2007. p. 413-414 
A exposição de Ana Rosa Carrara destacou-se pelo aprofundamento detalhado dos programas de produção multimídia, considerando-se os mais simples, além dos conceitos básicos para a produção, tais como Audacity, para spots e edição de áudio; Picture Manager, para pôsters e edição de imagem; Word, para edição de texto; Movie-Maker, para produção e edição de vídeo.

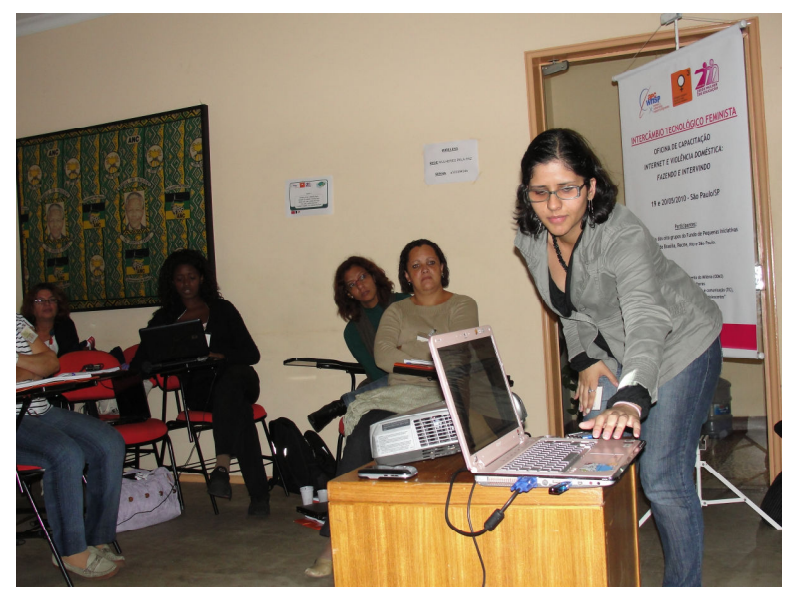

Imagem 6 - Ana Rosa Carrara (do Instituto Patrícia Galvão Comunicação e Mídia) focou os detalhes técnicos e de produção de programas multimídia. (foto: Vera Vieira)

Nilza Iraci, do Geledés Instituto da Mulher Negra, abordou o poder das redes de pessoas e instituições, potencializadas pela internet, para uma atuação articulada, com as relações pautadas por interdependência, complementaridade e horizontalidade. Tudo depende de uma vontade coletiva para realizar determinado objetivo, com valores compartilhados.

Segundo Castells (1999, p. 27) ${ }^{185}$,

[...] o surgimento da sociedade em rede traz à tona os processos de construção de identidade durante aquele período ['modernidade tardia' caracterizada por Giddens], induzindo

\footnotetext{
${ }^{185}$ Ibidem. p. 27.
} 
assim novas formas de transformação social. Isso ocorre porque a sociedade em rede está fundamentada na disjunção sistêmica entre o local e o global para a maioria dos indivíduos e grupos sociais. E também, acrescentaria, na separação, em diferentes estruturas de tempo/espaço, entre poder e experiência.

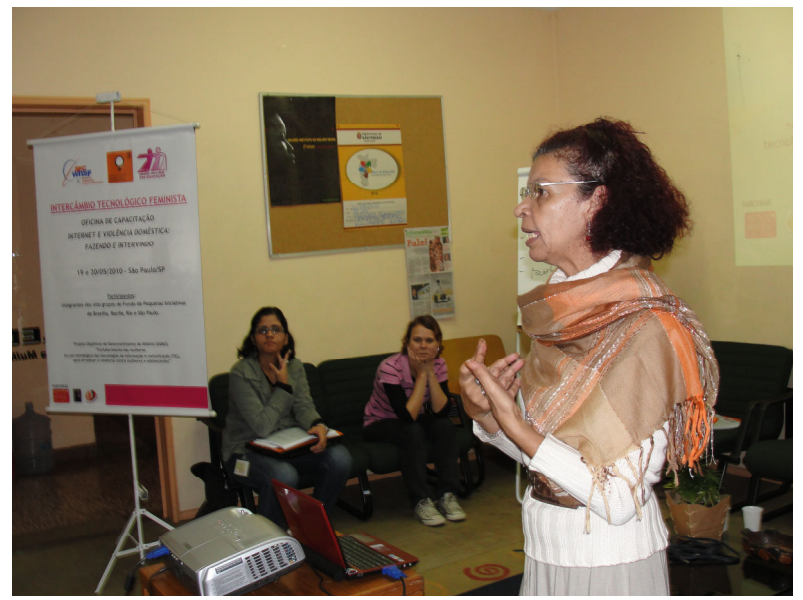

Imagem 7 - Nilza Iraci (do Geledés Instituto da Mulher Negra) discorreu sobre o potencial do trabalho em rede propiciado pelas TIC.

(foto: Vera Vieira)

Jacira Melo, do Instituto Patrícia Galvão Comunicação e Mídia, explicou os tipos de violência a que a mulher está sujeita, aprofundando-se na questão específica da violência doméstica. Também enfatizou alguns aspectos importantes relacionados às TIC e à violência contra a mulher, tais como: o grande diferencial trazido pela internet é que podemos consumir e produzir conteúdo, considerando, principalmente, a interatividade, como, por exemplo, nos casos de processos colaborativos; até fins do século passado, a produção possível de conteúdos ocorria por meio de cartilhas, panfletos, manifestações, programas de rádio, produção de vídeos, fotos, ilustrações e gráficos. Hoje, é possível a produção multimídia, o que significa a junção de texto, imagem e som; um dos grandes desafios no trabalho de produção de conteúdo sobre violência contra a mulher é a tradução da visão popular sobre o assunto, isto é, torna-se necessário dialogar com o senso comum; nessa produção, manter sempre em 
mente as perguntas - Para quem? O que produzir? Como? Qual o grau de interatividade? 0 produto vai oferecer ajuda e informação para a mulher que sofre violência por meio da hipermídia?

De acordo com Santaella (2007, p. 318-319) ${ }^{186}$,

[...] Hipermídia se refere, portanto, ao tratamento digital de todas as informações (som, imagem, texto, programas informáticos) com a mesma linguagem universal, uma espécie de esperanto das máquinas.

[...] Foram assim fundidas em um único setor do todo digital as quatro formas principais da comunicação humana: o documento escrito (livros, periódicos científicos, jornais, revistas); o audiovisual (televisão, vídeo, cinema); as telecomunicações (telefone, satélites, cabo); e a informática (computadores e programas informáticos).

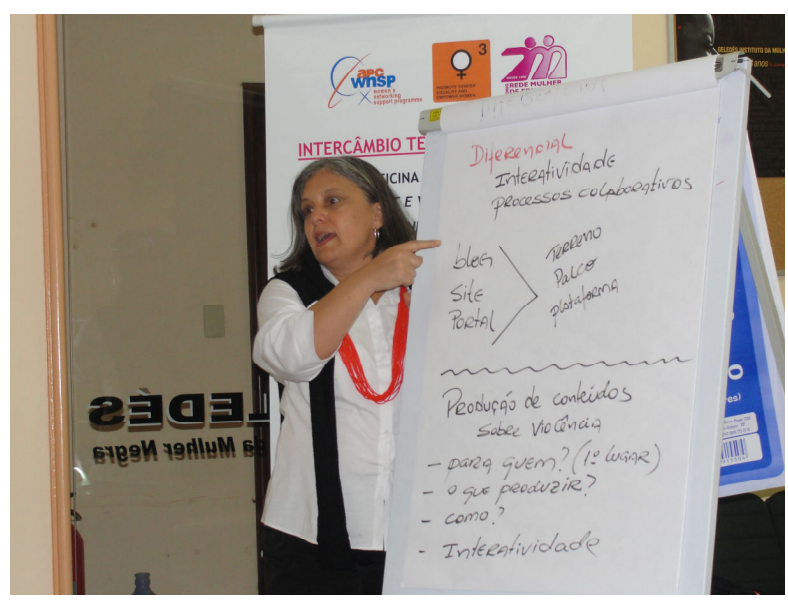

Imagem 8 - Jacira Melo (do Instituto Patrícia Galvão Comunicação e Mídia) falou sobre os tipos de violência sofridos pela mulher, elaborando, também, um roteiro de perguntas para uma adequada produção multimídia envolvendo a temática. (foto: Vera Vieira)

O dia seguinte foi reservado à produção de trabalhos em grupo. Como já

\footnotetext{
${ }^{186}$ Ibidem. p. 318-319.
} 
dito, a divisão foi feita mesclando-se participantes das diferentes entidades para que, pelo menos uma integrante de cada uma delas, estivesse em cada distinta produção e pudesse multiplicar o conhecimento adquirido, quando do retorno as suas respectivas regiões. O entusiasmo na concretização dos produtos multimídia foi tamanho que as participantes optaram por não interromper os trabalhos para o intervalo de almoço, seguindo empolgadas para a finalização até as $15 \mathrm{~h}$. Os produtos criados são os seguintes:

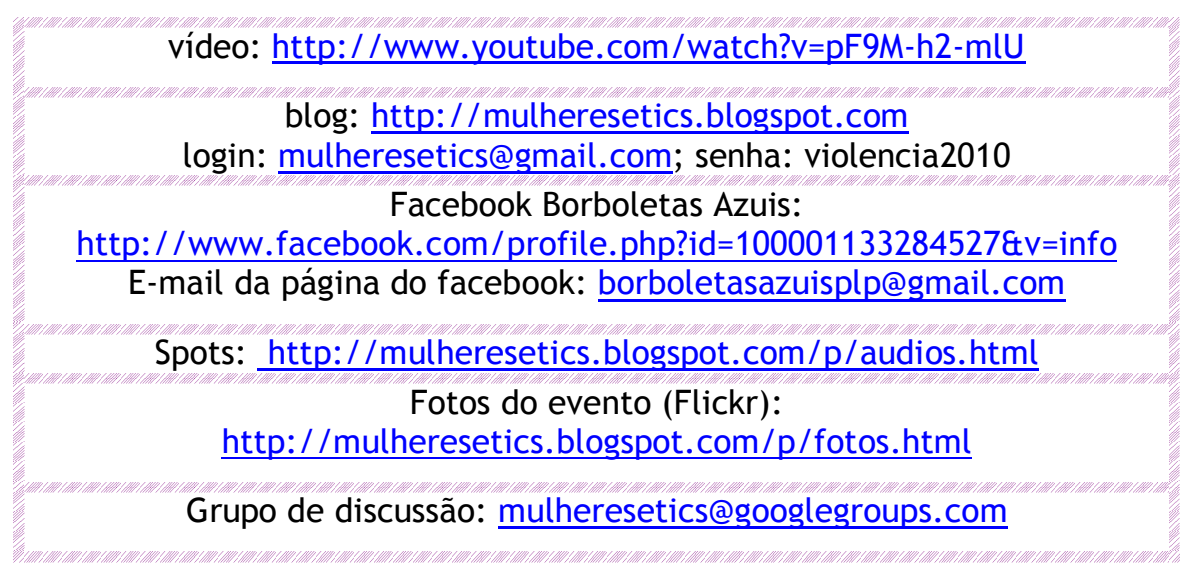

Tabela 1 - Lista dos produtos virtuais criados pelas participantes, que foram divididas em cinco grupos de trabalho.

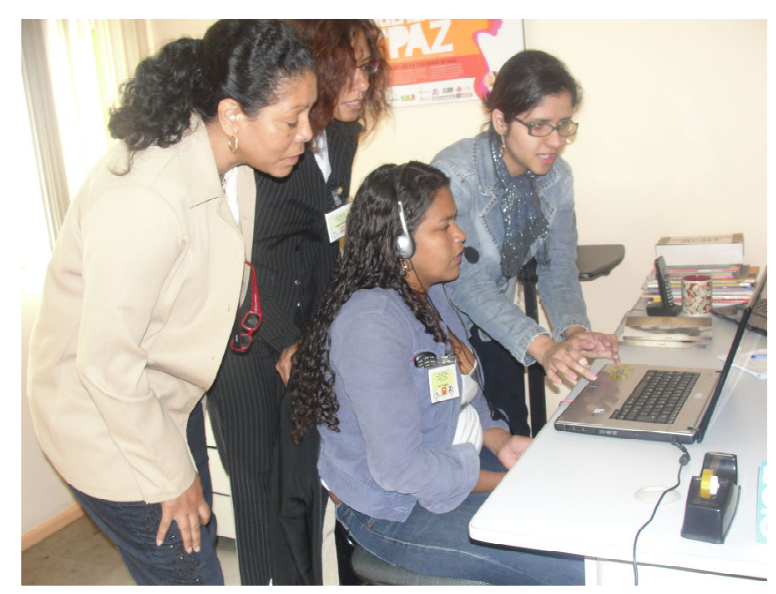

Imagem 9 - Integrantes de um dos grupos concentradas na produção multimídia, interconectando TIC e violência doméstica. (foto: Vera Vieira) 


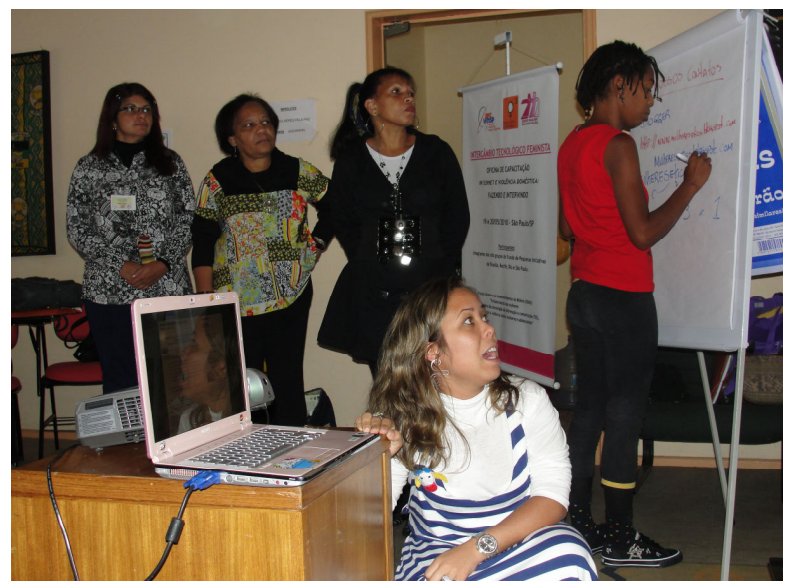

Imagem 10 - Integrantes de um dos grupos expõem todo o processo de criação do blog denominado "Mulheres e TIC", visando ao combate da violência doméstica. (foto: Vera Vieira)

Para finalizar a $1^{\text {a }}$ oficina de capacitação, todas as pessoas participantes se manifestaram sobre o consenso do saber e o processo de continuidade, delineando um quadro de resultados alcançados e de possibilidades tangíveis, que se somam ao quadro obtido ao findar da $2^{a}$ oficina de capacitação, conforme discriminação no item 6.2.2.3 desta tese. 
6.2.2.2 2a Oficina de capacitação: Intercâmbio Tecnológico Feminista Relatos Digitais sobre Violência Doméstica

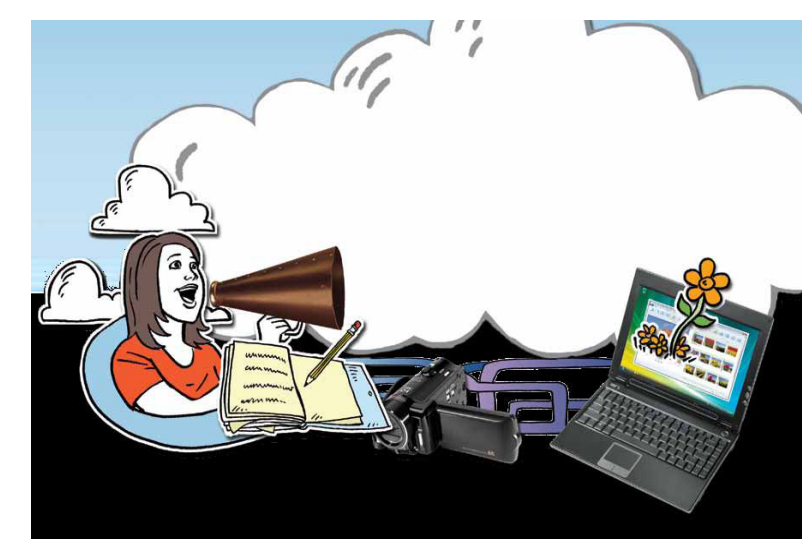

Imagem 11 / Ilustração - Conte-me um fato $e$ eu aprenderei / Conte-me uma verdade e eu acreditarei / Conte-me uma história e eu me lembrarei para sempre.

www.bbc.co.uk/tellinglives

A decisão sobre a pertinência da realização de uma oficina específica abordando relatos digitais sobre violência doméstica partiu do consenso entre as coordenadoras mundiais, regionais e locais do projeto ODM3. Considerou-se que se tratava de uma estratégia fundamental de apoio para as mulheres romperem com o ciclo da violência, auxiliando tanto depoentes vítimas como outras mulheres Brasil afora (ou de outros países de língua portuguesa) em situação similar que, ao acessarem a história, via internet, encontrassem informações e apoio no difícil processo de busca por uma vida pacífica e digna. Os relatos digitais são instrumentos potenciais que contribuem para a superação pessoal e de outras mulheres, o empoderamento pessoal e coletivo, a troca de experiências, o processo terapêutico de reconhecimento público da dor, a influência na esfera pública e privada e o aumento de informações e conhecimentos que levam à transformação da cruel realidade da violência doméstica. Essa realidade é vivenciada por mulheres de todo mundo, independentemente de classe social, raça/ etnia, nível educacional e localização geográfica. 
De acordo com Freire e Guimarães (2000, p. 27-28/30) ${ }^{187}$,

[...] Em primeiro lugar, nós estamos afirmando com esse título [Aprendendo com a própria história] que ninguém aprende fora da história. Segundo: deixamos muito claro que ninguém aprende individualmente apenas. Quer dizer, nós somos sócio-históricos, ou seres historicosociais e culturais, e que, por isso mesmo, o nosso aprendizado se dá na prática geral da qual fazemos parte, na prática social. Só que nós, você e eu, reconhecemos que não é possível afogar, fazer desaparecer a dimensão individual de cada sujeito histórico que se experimenta socialmente.

[...] A fala, afinal, emerge como a resposta necessária ao que homens e mulheres começam a fazer sobre o mundo.

Em quase duas décadas de trajetória convivendo com a temática da violência contra a mulher no universo das ONGs e levando em conta sua própria experiência enquanto sobrevivente de violência doméstica (ver depoimento em http: //www.youtube.com/watch?v=Z41KAIHS4J8, para a novela Viver a Vida), esta pesquisadora pode afirmar que a partir da verbalização do problema enfrentado, a vítima - que até então se sente paralisada em função, principalmente, da baixa auto-estima e do medo - descortina novas perspectivas com a convicção de ter caminhado $50 \%$ no difícil processo de superação. Esse tipo de relato da própria história, carregada de emoção, tem forte potencial de inspirar outras mulheres a seguirem o mesmo caminho de transformação e emancipação. A constatação do estado de impotência experimentado por mulheres em situação de violência é corroborada por Teles e Melo (2002, p. 23):

[...] A violência é uma das grandes formas de discriminação em razão de sexo/ gênero. Constitui violação dos direitos humanos e das liberdades essenciais, atingindo a cidadania das mulheres, impedindo-as de tomar decisões de maneira autônoma e livre, de ir e de vir, de expressar opiniões e desejos, de viver em paz em suas comunidades; direitos inalienáveis do ser humano. É uma

\footnotetext{
${ }^{187}$ FREIRE, P.; GUIMARÃES, S. Aprendendo com a própria história II. São Paulo: Paz e Terra, 2000, p. $27-$ 28
} 
forma de tortura que, embora não seja praticada diretamente por agentes do Estado, é reconhecida como violação dos direitos humanos desde a Conferência Mundial de Direitos Humanos realizada em Viena (Áustria), em 1993...

A oficina foi realizada em 4 e 5/11/2010, na cidade de São Paulo, com a participação 27 mulheres das 30 selecionadas, representantes de organizações do movimento feminista e de mulheres da Grande de São Paulo, em sua maioria, além de apenas uma delas residente no Rio de Janeiro (todas também integrantes das oito ONGs selecionadas), dada a escassez de verbas para a vinda de lideranças de outros estados. Visando ao sucesso da oficina, que envolvia a teoria e a prática de todas as etapas para a gravação e publicação de relatos digitais, houve a preocupação em convidar mulheres que já tivessem vivenciado a violência doméstica, assim como profissionais da área.

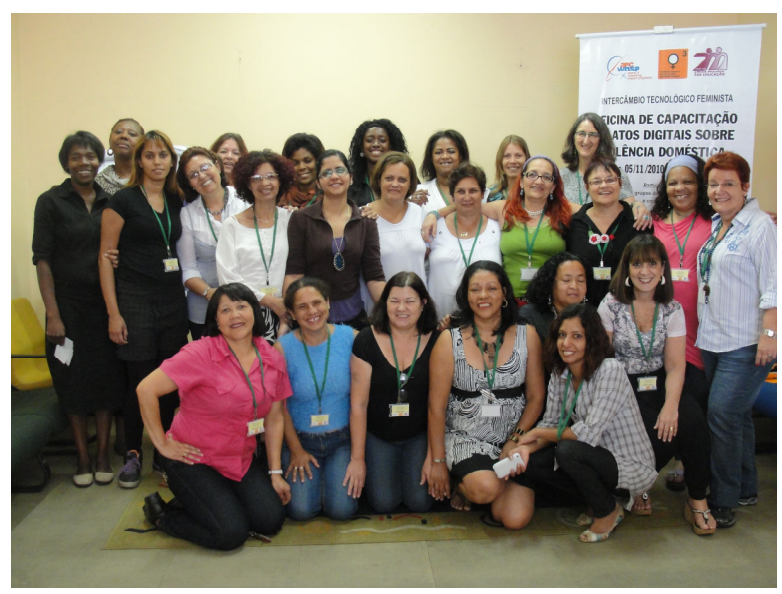

Imagem 12 - Participantes da $2^{\mathrm{a}}$ oficina, sendo a maioria pertencente a ONGs da Grande São Paulo, vítimas de violência doméstica ou profissionais da área. (foto: Rede Mulher)

Todas as participantes receberam uma pasta, contendo dois livros ${ }^{188}$ e uma

\footnotetext{
${ }^{188}$ PLOU, D.. Vieira, V. Mulher e Tecnologias - a virtualidade como espaço transformador das relações de gênero. SP. Rede Mulher. 2007

MELO, J. IRACI, N. VIEIRA, V. Fazendo Lobby - Guia para a participação de delegados/as no processo de negociação na $1{ }^{a}$ Conferência Nacional de Comunicação (Confecom). SP. Rede Mulher. 2009
} 
encadernação com as apresentações dos focos temáticos abordados e textos pertinentes, folder e pesquisas sobre a violência doméstica. Para qualificar os trabalhos em grupo - os quais ocuparam $70 \%$ do tempo total da oficina, em função da importância da produção e inserção dos relatos digitais - houve as seguintes exposições: a) A inserção das redes sociais digitais nas redes de apoio à mulher em situação de violência, a cargo de Nilza Iraci, do Geledés Instituto da Mulher Negra; b) Como elaborar roteiro para uma história digital e como encarar a tecnofobia, sob responsabilidade desta doutoranda; c) Instruções técnicas para o uso da câmera fotográfica em gravações, por Ana Rosa Carrara, do Instituto Patrícia Galvão Comunicação e Mídia. Houve a divisão prévia de quatro grupos, para a elaboração de roteiro, a gravação, a edição e a publicação no YouTube, mesclando depoimentos de vítimas de violência doméstica com o de profissionais da área. Desta vez, procurou-se agrupar participantes de uma mesma entidade ou com trabalho relacionado a ela.

As participantes mergulharam de forma dialógica nos conteúdos preparados para melhor qualificar a estratégia de comunicação a distância do movimento feminista e de mulheres no enfrentamento da violência doméstica, aproveitando o leque de possibilidades oferecido pela era digital. Segundo Levy (1996, p. 96) $)^{189}$

[...] 0 desenvolvimento da comunicação assistida por computador e das redes digitais planetárias aparece como a realização de um projeto mais ou menos bem formulado, o da constituição deliberada de novas formas de inteligência coletiva, mais flexíveis, mais democráticas, fundadas sobre a reciprocidade e o respeito das singularidades. Nesse sentido, poder-se-ia definir a inteligência coletiva como uma inteligência distribuída em toda parte, continuamente valorizada e sinergizada em tempo real.

Nilza Iraci ao ampliar o enfoque sobre as redes como estratégia para fortalecimento das mulheres em situação de violência doméstica, abordou a rede

\footnotetext{
${ }^{189}$ Ibidem. p. 96.
} 
social primária (familiares, vizinhos, amigas), secundária (instituições), intermediária (lideranças de diversas áreas) e com a revolução digital, a importância das redes sociais virtuais (grupos ou espaços específicos na internet, que permitem partilhar dados e informações). Destacou que se deve intervir estrategicamente em redes, já que elas possuem maior potencial para: gerar movimento de opinião pública; obter uma intervenção mais abrangente; incorrer em compromisso de todas as partes envolvidas; apresentar soluções inovadoras para os problemas emergentes; propiciar a realização de campanhas multimídia educativas e de sensibilização; envolver homens e mulheres nas atividades desenvolvidas; formar lideranças no âmbito governamental e não governamental; assim como galvanizar a intervenção na agenda política local, nacional e internacional na medida em que sejam reconhecidas.

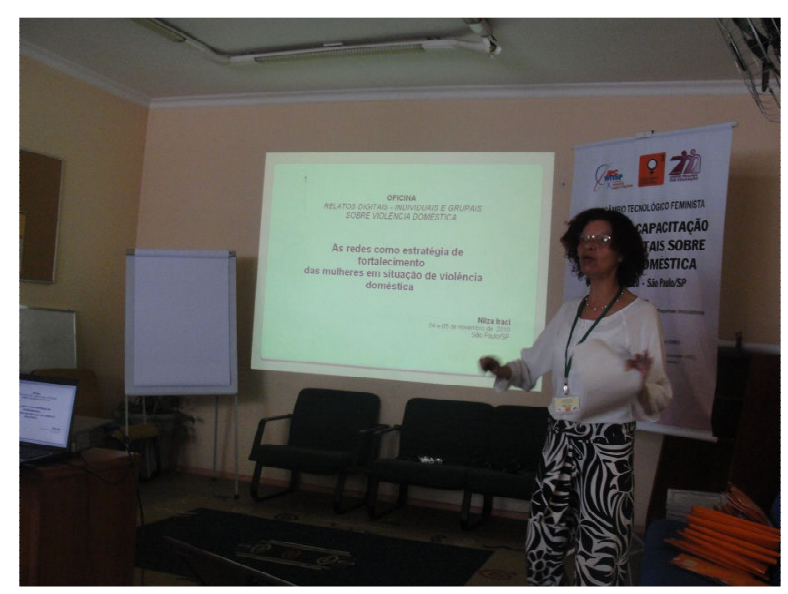

Imagem 13 - Nilza Iraci, da entidade parceira Geledés Instituto da Mulher Negra, falou sobre as redes como estratégia para fortalecimento das mulheres em situação de violência. (foto: Vera Vieira)

Cabe aqui revisitar Castells (1999, p. 419-421) para reforçar o potencial do irreversível funcionamento em rede proporcionado pelas TIC, levando em conta, principalmente, a identidade de resistência e a identidade de projeto dos movimentos sociais: 
[...] Juntamente com aparatos do Estado, redes globais e indivíduos centrados em si próprios, existem também comunidades formadas a partir da identidade de resistência. Entretanto, todos esses elementos não são capazes de coexistir pacificamente, uma vez que suas respectivas lógicas os excluem mutuamente.

Assim, a principal questão passa a ser o surgimento de identidades de projeto, potencialmente capazes de reconstruir uma nova sociedade civil e, enfim, um novo Estado. [...] Novas identidades de projeto não parecem surgir de identidades anteriormente presentes na sociedade civil da era industrial, mas sim a partir de um desenvolvimento das atuais identidades de resistência.

[...] As comunidades femininas, bem como os espaços de liberdade da identidade sexual, projetam-se na sociedade como um todo ao minar o patriarcalismo [patriarcado] e reconstruir a família a partir de uma base nova e igualitária, que implica o desaparecimento das relações marcadas pelo gênero nas instituições sociais, em oposição ao capitalismo e ao Estado patriarcais.

$\mathrm{Na}$ parte teórica reservada a esta pesquisadora, foi explicado o passo-apasso de como elaborar um bom roteiro para relatos digitais, enfatizando a importância de falar e interagir sobre a violência doméstica para transformar a realidade. 0 conteúdo se baseou principalmente no excelente material disponibilizado pela University of Houston (The educational uses of Digital Storytelling) ${ }^{190}$ e da Microsoft (Tell a Story, Become a Lifelong Learner. Digital Storytelling Learning Projects) ${ }^{191}$. Na apresentação, também foi abordada a questão da tecnofobia que possui um forte recorte de gênero e geração, já que as mulheres, principalmente aquelas nascidas na era analógica, não foram socializadas para lidar com a tecnologia da mesma forma que os homens.

Relatos digitais são filmes curtos, geralmente, de três a 10 minutos de duração, podendo ser feitos com equipamentos que estão ao alcance de grande

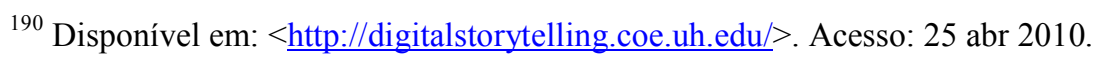

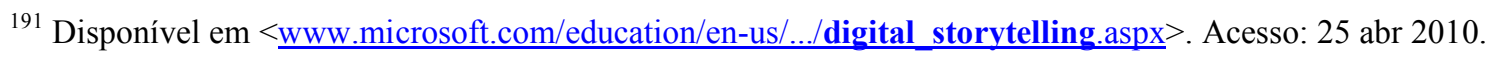


parte da população, como a câmera digital e o aparelho celular, além do computador e da internet. Têm o potencial de proporcionar às mulheres a autoria da própria história. Cada pessoa tem uma história para contar. A tecnologia permite que qualquer pessoa conte sua história do seu próprio jeito. Vera Vieira enfatizou tratar-se de uma forma de expressão moderna da arte ancestral de contar histórias, para compartilhar sentimentos, informações, conhecimentos, sabedorias e valores. Na história humana, cada tecnologia propicia formas diferentes de contar história, de se criar uma narrativa. As TIC unem a informática, os sistemas digitais e a internet, propiciando a produção de conteúdo multimídia, que é uma mescla de texto, som e imagem - com interatividade. Os aspectos revolucionários das TIC estão ligados à produção de conteúdo (não só consumo) e à interatividade (comunicação instantânea e produção em processos colaborativos).

Barbero (2006, p. 4) ${ }^{192}$ destaca, em sua reflexão sobre experiência e relato na era digital, que,

[...] frente à globalização econômica e tecnológica, que diminui a importância dos territórios desvalorizando os referentes tradicionais de identidade, as culturais locais, étnica e de gênero, se auto-revalorizam exigindo, cada dia com maior autodeterminação, seu direito a contar suas histórias e também a contar - ser levadas em conta - nas decisões econômicas e políticas que lhes dizem respeito. A polissemia da palavra contar não pode ser mais significativa: para que a pluralidade das culturas do mundo seja politicamente considerada é indispensável que a heterogeneidade das identidades possa ser contada, narrada. Pois a relação da narração com a identidade não é apenas expressiva, mas sim constitutiva: a identidade é uma construção que se relata, não há identidade cultural se não é contada. [tradução minha]

A seguir, foram destacados os sete elementos de um bom relato digital: 1)

\footnotetext{
192 MARTÍN-BARBERO, J. Narrativas estalladas - entre oralidades recuperadas y visualidades hegemônicas. Palestra apresentada no Congresso Latinoamericano de Jalla, Bogotá, 2006, en prensa. (disponível na apostila Cartografias culturales de la sensibilidad y la tecnicidad, distribuída por ocasião das aulas ministradas na USP/ECA, no período de 15-19/9/2008.
} 
ponto de vista (qual o principal ponto de vista do relato e qual a perspectiva de quem fala?); 2) uma pergunta dramática (qual a pergunta-chave que cativará a atenção de quem assiste e que será respondida no final do relato?); 3) conteúdo emocional (seriedade do assunto que se torna vivo de forma pessoal e poderosa, conseguindo uma conexão com a audiência); 4) sua própria voz (oportunidade de personalizar o relato de uma forma que a audiência entenda o conteúdo); 5) o poder do fundo musical (a música e outros sons podem dar um ótimo efeito no relato); 6) objetividade (não tente explicar demasiadamente; procure encontrar a medida certa); 7) ritmo (o desenvolvimento do relato não deve ser nem lento, nem apressado).

O passo-a-passo para o relato digital sobre violência doméstica prevê: 1) seleção do tópico do relato (depoimento sobre o processo de superação de mulher vítima de violência; depoimento de profissional, etc.); 2) realização de uma reunião de chuva de idéias (qual o foco temático a ser abordado; identificação ou não da depoente, em termos de nome e imagem; nível de emoção e postura no depoimento; principal mensagem a ser transmitida; imagens a serem utilizadas...); 3) criação de um pré-roteiro (com as fases do depoimento e das imagens); 4) revisão (para modificar imagens e a organização do relato); 5) edição (tempo, imagens e narração; lidando com o programa Movie Maker); 6) divulgação (lidando com o YouTube).

Para a abordagem da questão da tecnofobia - que é o medo da tecnologia moderna - esta pesquisadora ilustrou a apresentação com um vídeo disponível no YouTube, intitulado Suporte Técnico na Idade Média ${ }^{193}$, visando à sensibilização para a discussão da temática. Ao final, para exemplificar a concretização de um relato digital, foi apresentado o depoimento sobre superação de violência doméstica fornecido por Vera Vieira ${ }^{194}$, para a novela

\footnotetext{
193 Disponível em: <http://ogestor.wordpress.com/2009/08/03/tecnofobia-saiba-o-que-e/>. Acesso: 10 out 2010.

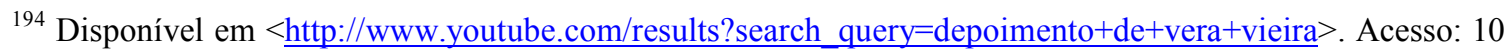
out 2010 .
} 
Viver a Vida, que foi ao ar, na TV Globo, em 25/09/2009.

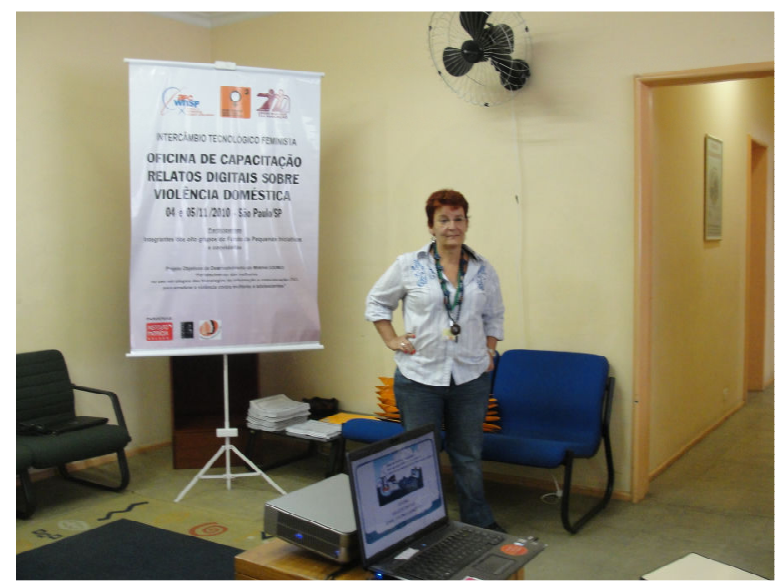

Imagem 14 - Vera Vieira teorizou sobre relatos digitais, fornecendo um guia com o passo-apasso para a produção e publicação. (foto: Rede Mulher)

As orientações técnicas para o processo de produção de relatos digitais ficou a cargo de Ana Rosa Carrara. Ela explicou detalhadamente como gravar utilizando uma câmera digital ou aparelho celular, como salvar o arquivo no computador, como editar o material e como publicar o vídeo no YouTube. À medida que ia explicando o passo-a-passo, as participantes já realizavam o exercício prático, num real ambiente de rompimento com o medo da tecnologia, na medida em que acontecia o domínio da técnica. 


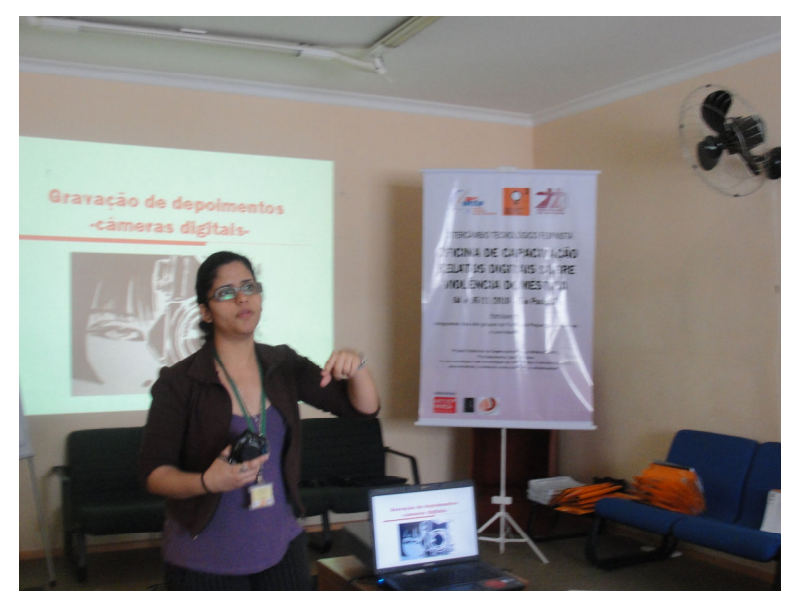

Imagem 15 - Ana Rosa Carrara desvendou os detalhes técnicos para a produção, edição e divulgação de relatos digitais. (foto: Vera Vieira)

Segue, abaixo, a relação dos links para as produções realizadas, que incluem depoimentos de vítimas de violência, orientações sobre a problemática e declarações sobre o processo de aprendizagem:

http: / / www.youtube.com/user/Mulheresetics\#p/a/u/1/iB3VnSgPpzc
http://www.youtube.com/user/Mulheresetics\#p/a/u/0/kP4ZvVXjkP8
$\underline{\text { http:/ www.youtube.com/user/Mulheresetics\#p/a/u/2/tslaLumfp7o }}$
http://www.youtube.com/watch?v=BFd3DnKu-gg
Fotos do evento:
http://mulheresetics.blogspot.com/p/fotos.html

Tabela 2 - Lista das produções realizadas pelas participantes, que foram divididas em quatro grupos de trabalho. 


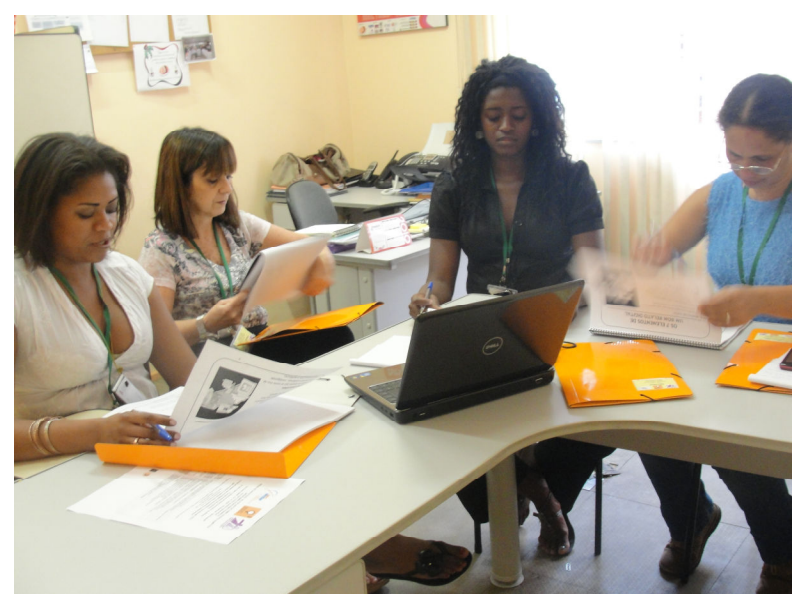

Imagem 16 - Integrantes de um dos grupos se concentram nas etapas de produção de um relato digital. (foto: Vera Vieira)

\subsubsection{Consenso do saber e possibilidades de continuidade}

Ao final desta $2^{\mathrm{a}}$ oficina de capacitação, como ocorreu por ocasião da realização da $1^{a}$, houve um diálogo entre todas participantes, em busca da resposta à pergunta de Habermas (1989, p. 91), e que se resume a: "com que modo de agir em comum as pessoas querem se comprometer?" Depois de um processo de criação envolvendo as dimensões práticas, mas também as da subjetividade e intersubjetividade, chega-se ao momento do entendimento pleno que se traduz no verdadeiro ato de comunicar. Comunicação, como a própria palavra enseja, significa tornar COMUM a AÇÃO. Segue, abaixo, uma relação dos aspectos consensados em ambas as oficinas, após o exercício prático de novas dinâmicas de comunicação, que demonstram a ampliação do leque de estratégias de intervenção política e de atuação. Esses resultados se somam e estão em consonância com as ações ocorridas no processo de multiplicação, o qual será relatado no capítulo voltado às considerações finais, como mais uma demonstração da viabilidade concreta de novos projetos junto aos grupos de base: 
- 0 aprendizado gestado nas duas oficinas comprova a existência de outras formas de expressão por meio da comunicação a distância utilizando-se as TIC, que promovem uma mudança de mentalidade e, consequentemente, o avanço da luta das mulheres pela equidade de gênero, graças às novas formas de produção, interatividade, compartilhamento e amigabilidade.

- O projeto aponta para a possibilidade concreta de multiplicação da comunicação a distância Brasil afora, principalmente por utilizar recursos digitais elementares, que são acessíveis a grande parte da população.

- As TIC promovem um relacionamento mais horizontal entre quem ensina e quem aprende; ambos aprendem e ensinam ao mesmo tempo. Esta vivência será aplicada nos grupos de base.

- Diferentes gerações conseguem entrar em sintonia no universo das TIC, mesmo considerando-se a brecha geracional. As entidades de base participantes estarão atentas a este aprendizado durante o processo de multiplicação do saber.

- Houve um avanço considerável no âmbito do domínio tecnológico das lideranças participantes, assim como na consciência sobre a importância de se incluir mulheres residentes na área urbana e rural, pertencentes à diversidade dos movimentos de mulheres, tais como negro, lésbico, promotoras legais populares, jovens, etc. Trata-se de um modelo a ser replicado.

- Fortalecimento da conexão entre TIC e relações de gênero pelos grupos de base de algumas regiões brasileiras, com potencial de ressonância para outras localidades.

- Ampliação de horizontes no que concerne ao uso da internet, principalmente para a prevenção e combate à violência contra a mulher. 
- Criação de uma rede específica com o objetivo de fortalecer a luta contra a violência a mulher, que pode ser amplificada, assim como o aumento da capacidade de sistematização e proposição de políticas públicas e estratégias de intervenção.

- Fortalecimento dos laços de solidariedade entre as mulheres, especialmente considerando-se 0 fato de que as participantes pertencem a diferentes áreas geográficas em um país com dimensões continentais, além da diversidade de raça/ etnia, geração e orientação sexual.

- Multiplicação de iniciativas de debates descentralizados, processos de formação voltados para a conexão entre TIC, gênero, desenvolvimento, empoderamento, violência contra a mulher e políticas públicas.

- Aumento da conscientização, por parte de lideranças históricas do movimento feminista e de mulheres, da necessidade de incluir TIC na agenda estratégica.

- Necessidade de ampliação dos processos de capacitação, como este que acaba de acontecer, tanto em nível nacional como local.

- Incidência da pesquisa projeto nas instâncias de poder governamentais e empresarias (responsabilidade social), com a participação em eventos e realização de entrevista.

- Incidência do projeto nas instâncias de poder governamentais e empresarias (responsabilidade social), com a participação em eventos e realização de entrevista.

- A experiência das duas oficinas oferece o fermento básico para o início de um projeto experimental sobre uma metodologia específica para trabalhar com mulheres e homens a questão da violência doméstica, nas diferentes regiões brasileiras, tanto presencialmente como em termos de comunicação a distância. 
0 rol de possibilidades descortinado pelas mídias digitais em prol do avanço da luta pela equidade de gênero reafirma a teoria da "comunicação todos-todos", explorada por Lévy (1996, p. 113), e não mais "um-todos", caracterizada pelas mídias clássicas. Assim, são concretizadas novas narrativas da identidade feminina. Como bem salienta o autor,

[...] No ciberespaço, em troca, cada um é potencialmente emissor e receptor num espaço qualitativamente diferenciado, não fixo, disposto pelos participantes, explorável. Aqui, não é principalmente por seu nome, sua posição geográfica ou social que a pessoas se encontram, mas segundo centros de interesses, numa paisagem comum do sentido ou do saber.

[...] o ciberespaço oferece instrumentos de construção cooperativa de um contexto comum em grupos numerosos e geograficamente dispersos. A comunicação se desdobra aqui em toda a sua dimensão pragmática. Não se trata mais apenas de uma difusão ou de um transporte de mensagens, mas de uma interação no seio de uma situação que cada um contribui para modificar ou estabilizar, de uma negociação sobre significações, de um processo de reconhecimento mútuo dos indivíduos e dos grupos via atividade de comunicação. 0 ponto capital é aqui a objetivação parcial do mundo virtual de significações entregue à partilha e à reintretação dos participantes nos dispositivos de comunicação todos-todos.

A abordagem do próximo item diz respeito exatamente ao aprofundamento da instância teórica do objeto desta tese, que busca alicerçar o principal pressuposto voltado para o potencial revolucionário da comunicação à distância (todos-todos) na desconstrução dos estereótipos de identidade da mulher que, há milênios, vem sendo socialmente construída, culturalmente aceita e historicamente mantida. 


\subsection{As possibilidades de diferentes dinâmicas de construção simbólica nas novas formas comunicacionais digitais}

Como vem sendo matizado no transcorrer desta tese, as TIC são os novos instrumentos utilizados pela maior parte da humanidade para a produção, armazenamento e transmissão de informação e conhecimento, representando uma revolução que atinge três esferas: a técnica, a das formas de aprendizagens e a do estilo de relacionamentos pessoais e inter-pessoais. As TIC trazem em seu bojo a desorganização espacial e temporal. Num mergulho histórico sobre as transformações causadas pelas diferentes revoluções de comunicação, Di Felice (2008, p. 20-21/ 44-45) ${ }^{195}$ destaca que,

[...] a relação entre mídia, tecnologia de comunicação e participação pública resulta mais facilmente compreensível. Além de mudar as opiniões e as formas de interagir, a introdução de um novo meio de comunicação e de uma nova tecnologia comunicativa, num determinado momento da história da humanidade, passou a atingir a esfera da interação com o mundo, contribuindo para determinar a transformação da estrutura de percepção da realidade.

[...] Como foi descrito pelos diversos autores (Lazarsfeld, Shannon-Weaver, Eco e Fabbri), em níveis diferentes de complexidade, a forma analógica se exprime pelo repasse das informações procedente de um emissor em direção a um receptor através da emissão de um fluxo unilateral distribuído por canais e com as intervenções de ruídos.

Ao contrário de tal modelo, a comunicação digital apresenta-se como um processo comunicativo em rede e interativo. Neste, a distinção entre receptor é substituída por uma interação de fluxos informativos entre o internauta e as redes, resultante de uma navegação única e individual que cria um rizomático processo comunicativo entre arquiteturas informativas (site, blog, comunidades virtuais etc., conteúdos e pessoas).

195 Ibidem. p.20/21/44/45 
A experiência humana - que se dá juntamente com as tecnologias criadas - é repleta de significados e representações. De acordo com Deleuze e Guattari, (2009. p. 13/21-22/25/37) ${ }^{196}$, “a lógica binária [das TIC] é a realidade espiritual da árvore-raiz", e "toda lógica da árvore é uma lógica do decalque e da reprodução". Segundo os autores,

[...] Diferentemente é o rizoma, mapa e não decalque. Fazer o mapa, não o decalque. A orquídia não reproduz o decalque da vespa, ela compõe um mapa com a vespa no seio de um rizoma. Se o mapa se opõe ao decalque é por estar inteiramente voltado para uma experimentação ancorada no real. O mapa não reproduz um inconsciente fechado sobre ele mesmo, ele o constrói. Ele faz parte do rizoma. 0 mapa é aberto, é conectável em todas as suas dimensões, desmontável, reversível, suscetível de receber modificações constantemente. Ele pode ser rasgado, revertido, adaptar-se a montagens de qualquer natureza, ser preparado por um indivíduo, um grupo, uma formação social.

[...] Não devemos mais acreditar em árvores, em raízes ou radículas, já sofremos muito. Toda a cultura arborescente é fundada sobre elas, da biologia à linguística. Ao contrário, nada é belo, nada é amoroso, nada é político a não ser que sejam arbustos subterrâneos e as raízes aéreas, o adventício e o rizoma. [...] Um rizoma não começa nem conclui, ele se encontra sempre no meio, entre as coisas, inter-ser, intermezzo. A árvore é filiação, mas o rizoma é aliança, unicamente aliança. A árvore impõe o verbo 'ser', mas o rizoma tem como tecido a conjunção 'e... e... e...'.

As TIC, ao integrarem telecomunicações com informática, além da troca de informações em velocidade instantânea, propiciam a criação colaborativa de conteúdo a distância em formato multimídia - mescla de texto, som e imagem , o que implica dizer que a interatividade é o aspecto mais relevante desta revolução, acarretando novas narrativas. Para Di Felice (2008, p. 48) ${ }^{197}$,

\footnotetext{
196 Ibidem. p.13/21/22/25/37

${ }^{197}$ Ibidem. p.48
} 
[...] Assim sendo, a sociedade informacional seria uma forma específica de organização social em que a geração, o processamento e a transformação das informações tornam-se fonte fundamental da sociabilidade.

Nesta concepção, a ideia moderna de esfera pública como emanação dos meios impressos e audiovisuais deve ser repensada e submetida, na época das redes digitais, às qualitativas transformações. Nessa nova fase, a tecnologia, enquanto interface e interatividade, deixa de ser 'extensão dos sentidos' para se tornar interna e, enquanto forma tecnológica de inteligência e de relações socialmente habitável.

As recentes manifestações nos países árabes, intitulada Primavera Árabe, que aconteceram mais fortemente na Tunísia (dezembro de 2010), no Egito (janeiro de 2011) e na Líbia (fevereiro 2011) levaram à reformulação ${ }^{198}$ dos governos ditatoriais, ação esta considerada sem precedentes em termos de estratégia da população. As revoltas ficaram conhecidas como a "revolução do Facebook e do Twitter", pois os sites de relacionamentos e os celulares foram as armas mais utilizadas pela população para organizar os protestos. A tática surtiu efeito tão vitorioso que fez com que os governos bloqueassem tais serviços. No final de 2010, em 30/12, o jornal Folha de S.Paulo, publicou um caderno especial intitulado "O balanço da década", em que destaca, na página 7, o seguinte

198 "Em 14 de janeiro, Zine el-Abidine Ben Ali, que governava a Tunísia desde 1987, fugiu do país rumo à Arábia Saudita. Era a única saída para o ditador diante da crescente onda de manifestações populares iniciada na cidade de Sidi Bouzid, em dezembro, e que naquele dia chegou à capital, Túnis. Ao deixar o poder, Ben Ali se tornou o primeiro governante da história do mundo árabe a ser derrubado por um movimento popular, um acontecimento que fez alguns analistas vislumbrarem um efeito dominó que marcaria o início de uma era democrática no norte da África e no Oriente Médio." Disponível em: $<$ http://revistaepoca.globo.com/Revista/Epoca/0,EMI204306- 15227,00.html>. Acesso: 12 Dez 2011.

De acordo com notícia divulgada em 29/1/11, "Em novo dia de protestos, Egito estende toque de recolher Medida é anunciada pouco depois de gabinete de governo apresentar renúncia, numa tentativa de Mubarak de frear manifestações - extensão do toque de recolher foi anunciada logo após a renúncia do gabinete de governo do presidente Hosni Mubarak, apresentada formalmente no início da tarde. Os ministros atenderam a um pedido de Mubarak, que com a mudança tenta frear a onda de manifestações sem precedentes que começou na terça-feira. Apesar da mudança de gabinete e do novo toque de recolher, milhares de manifestantes desafiam a medida e continuam nas ruas do centro do Cairo, no quinto dia consecutivo de protestos. Manifestações também acontecem em cidades como Suez e Alexandria, onde centenas pedem a renúncia de Mubarak." Disponível em:

$<\underline{\text { http://ultimosegundo.ig.com.br/mundo/em+novo }+ \text { dia }+ \text { de }+ \text { protestos }+ \text { egito }+ \text { estende }+ \text { toque }+ \text { de }+ \text { recolher } / \mathrm{n} 123}$ 7974293540.html> Acesso em: 10 nov 2011. 
trecho a respeito do papel das redes sociais:

[...] Elas mudaram o jeito como nos relacionamos. O Orkut foi o precursor e até hoje é o mais popular no Brasil. No mundo, tem 85 milhões de usuários. Mas foi o Facebook (500 milhões de usuários), ao lado do Twitter (175 milhões) que mostrou o real poder das redes sociais.

Ao discorrer sobre a característica da horizontalidade da internet - a maior rede de pessoas que já existiu em toda a história da humanidade - , com a possibilidade de distribuição democrática de poder entre os usuários, Di Felice (2008, p. 52/53) $)^{199}$ traz um enfoque sobre a duplicidade de níveis da interação e de seu potencial transformador, o que contribui para embasar pressupostos desta pesquisa-ação:

[...] de um lado, a interação dinâmica e fluida dos circuitos informativos que se definem como um resultado de interações entre sujeitos, interfaces e territórios; e, de outro, a interação dos processos de decisão que, nesses novos contextos surgem como prática colaborativa de soluções de problemáticas. De um ponto de vista político, assistimos, portanto, à passagem de uma prática de interação midiática e territorial para outra atópica, colaborativa e interativa.

[...] As redes digitais instauram uma forma comunicativa feita de fluxos e de troca de informações 'de todos para todos'.

Sem dúvida, as TIC provocam um verdadeiro caos diante das inusitadas noções de tempo e espaço, mas, paradoxalmente, contêm a força propulsora para a transformação da humanidade. Para o filósofo italiano Vattimo (1992, p. $10 / 17)^{200}$, seria a 'sociedade transparente?':

[...] Como se terá observado, a expressão 'sociedade

\footnotetext{
${ }^{199}$ Ibidem. p.52/53

${ }^{200}$ Ibidem. p. 10/17
} 
transparente' é aqui introduzida em termos interrogativos. 0 que pretendo afirmar é: a) que no nascimento de uma sociedade pósmoderna um papel determinante é desempenhado pelos mass media; b) que estes caracterizam esta sociedade não como uma sociedade mais 'transparente', mais consciente de si, mais 'iluminada', mas como uma sociedade mais complexa, até caótica; e por fim, c) que é precisamente neste relativo 'caos' que residem as nossas esperanças de emancipação.

[...] Filósofos niilistas como Nietzsche e Heidegger (mas também pragmatistas como Dewey ou Wittgenstein), ao mostrarem que o ser não coincide necessariamente com aquilo que é estável, fixo, permanente, mas tem antes a ver com o acontecimento, o consenso, o diálogo, a interpretação, esforçam-se por nos tornar capazes de alcançar esta experiência de oscilação do mundo pósmoderno como chance de um novo modo de ser (talvez: finalmente) humanos.

“Um novo modo de ser humanos”, obviamente, implica na experiência de vida que leve em conta a democratização das relações cotidianas entre mulheres e homens. E a mídia, que tem “importância fundamental para a experiência”, já que "ela anima, reflete e exprime a experiência, nossa experiência, dia após dia” (SILVERSTONE, 2005. p. 147) ${ }^{201}$, levando em conta principalmente a revolução propiciada pelas TIC, poderia contribuir para outra revolução, a de gênero - possivelmente a $4^{\mathrm{a}}$ onda do feminismo - , no sentido de alterar 0 binômio dominação-subordinação e as consequiências negativas para toda a sociedade? Ao trazer consigo um novo modo de pensar, sentir e agir, as TIC estariam configurando "um novo modo de ser humanos", como profetizado por Vattimo? A consistência da experiência para chegar a esse resultado, para Silverstone, está relacionada à luta pela vida moral, no espaço público e privado:

[...] $\mathrm{Na}$ esfera privada, dentro dos lares do mundo, as comunicações e os valores públicos, sem dúvida mediados por alto-falantes e telas, tornam-se sujeitos ao que chamei em outro contexto de 'economia moral' da família (Silverstone, 1994). [...] Pretendo aqui sugerir algo mais forte, porém certamente mais

\footnotetext{
${ }^{201}$ Ibidem. p. 147
} 
controverso: que o doméstico é um lugar importante onde a luta pela vida moral ocorre no mundo, e é uma luta que implica o desejo e a capacidade de nos posicionarmos como seres conscientes, cuidadosos em relação ao Outro.

No entanto, quando ideias, imagens, valores e as chamadas verdades cruzam o limiar entre vidas e espaços públicos e privados, seus significados estão sujeitos a reexame, rejeição, transcendência, de acordo com uma série de valores que sustentam, unicamente, o grupo social (família ou não) que ocupa esse espaço privado. É, de fato, na relação com a mídia, com a comunicação e a representação mediadas que cada vez mais temos de nos posicionar como sujeitos morais, pois muitas vezes - Outro aparece para nós apenas sob esse aspecto, e essas representações são checadas, quando possível, à luz das experiências da vida cotidiana." ${ }^{202}$

Tentando dialogar com a reflexão de Silverstone, cabe inserir a contraposição do cuidado em relação “à Outra”, ao invés de 'ao Outro', no posicionamento da humanidade para "um outro mundo possível”, apregoado no slogan das inúmeras versões do Fórum Social Mundial - reconhecido evento da sociedade civil, para a discussão de formas alternativas e sustentáveis em termos sociais, políticos, culturais e econômicos. Segundo Levy $(2009)^{203}$,

[...] as origens do FSM podem ser encontradas em uma série de fontes e experiências internacionais. Entre elas estão as várias conferências da ONU ocorridas ao longo da década de 1990, os Encontros Intercontinentais pela Humanidade e contra o Neoliberalismo organizados pelos Zapatistas em 1996, 1997 e 1999 no México, na Espanha e no Brasil, as manifestações contra a OMC em Seattle em 1997, contra o Banco Mundial em Washington e em Praga no ano 2000 (entre outras), contra a Cúpula das Américas em Québec em 2001 e contra o G-8 em Gênova no mesmo ano e, finalmente, o Jubileu do Ano 2000. Entre os atores envolvidos na concepção e na organização do FSM encontram-se intelectuais franceses, militantes de partidos políticos brasileiros, ONGs, os

\footnotetext{
${ }^{202}$ Ibidem. p.258/259.

${ }^{203}$ Levy, C. Influência e contribuição: a igreja católica progressista brasileira e o fórum social mundial. RJ: Relig. soc. Volume 29. $n^{\circ}$. 2. Também disponível em $<$ http://www.scielo.br/scielo.php?script=sci_arttext\&pid=S0100-85872009000200009\&lng=pt\&nrm=iso $>$. Acesso: 10 Out 2011.
} 
movimentos das populações pobres e uma elite antiglobalização. [...] Portanto, o FSM pode ser considerado uma resposta às limitações da participação nos espaços das organizações internacionais e das resistências isoladas aos processos de governança formal. Ademais, em vez de se concentrar em tópicos ou temas específicos, o FSM abarca uma pluralidade de problemáticas (como as mulheres, os trabalhadores rurais e os povos indígenas, por exemplo), mas agregando diferentes causas, lutas e correntes, bem como as suas práticas.

Mas, como se dá a materialização das novas dinâmicas de construção simbólica no âmbito público e privado? Como essas dinâmicas diferentes vão contribuir para desconstruir as imagens estabelecidas para "coisas de mulher $\mathbf{x}$ coisas de homem"? Afinal, são essas imagens estereotipadas que se materializam no número insignificante de mulheres em cargos de poder, nas estatísticas estarrecedoras de vítimas da violência doméstica mundo afora, na divisão desigual das tarefas do lar, acarretando à mulher a sobrecarga da tripla jornada ${ }^{204}$ - constituída pelas tarefas produtivas, reprodutivas e comunitárias.

$\mathrm{Na}$ construção de um axioma ${ }^{205}$ que demonstre as possibilidades de mudança com as formas totalmente novas de construção da subjetividade, a pesquisadora acadêmica e escritora feminista Donna Haraway $(2009 \text {, p. 36) })^{206}$ desenvolve seu pensamento a partir da imagem de um ciborgue - um misto de animal e máquina, como, por exemplo, um ser humano com uma perna

\footnotetext{
${ }^{204}$ Entende-se como trabalho produtivo o que é feito em troca de pagamento (dinheiro ou mercadoria); o trabalho reprodutivo não se limita às responsabilidades de gerar e criar filhos, incluindo as tarefas domésticas que são desempenhadas com a finalidade de manter e reproduzir a força de trabalho; o trabalho de gestão comunitária se refere à provisão e manutenção de bens de consumo, tais como habitação, abastecimento d'água, serviço de saúde e educação, ou seja, bens necessários à reprodução ampliada da força de trabalho. Disponível em: <www.redemulher.org.br>. Acesso: 10 Fev 2011.

${ }^{205} \mathrm{Na}$ lógica tradicional, um axioma ou postulado é uma sentença ou proposição que não é provada ou demonstrada e é considerada como óbvia ou como um consenso inicial necessário para a construção ou aceitação de uma teoria. Por essa razão, é aceito como verdade e serve como ponto inicial para dedução e inferências de outras verdades (dependentes de teoria). Disponível em: <http://pt.wikipedia.org/wiki/Axioma>. Acesso: 10 Fev 2011.

${ }^{206}$ HARAWAY, D. Manifesto ciborgue - Ciência, tecnologia e femiismo-socialista no final do século XX. In: Antropologia do ciborgue - As vertigens do pós-humano (Donna Haraway, Hari Kunzru e Tomaz Tadeu org). Autêntica Editora Ltda. Belo Horizonte/MG. 2a.ed. 2009. p.36
} 
mecânica:

[...] Um ciborgue é um organismo cibernético, um híbrido de máquina e organismo, uma criatura de realidade social e também uma criatura de ficção. Realidade social significa relações sociais vividas, significa nossa construção política mais importante, significa uma ficção capaz de mudar o mundo. Os movimentos internacionais de mulheres têm construído aquilo que se pode chamar de 'experiência das mulheres'. Essa experiência é tanto uma ficção quanto um fato do tipo mais crucial, mais político. A libertação depende de sua imaginativa apreensão e, portanto, da consciência e da apreensão da possibilidade. O ciborgue é uma matéria de ficção e também de experiência vivida - uma experiência que muda aquilo que conta como experiência feminina no final do século XX. Trata-se de uma luta de vida e de morte, mas a fronteira entre a ficção científica e a realidade social é uma ilusão ótica.

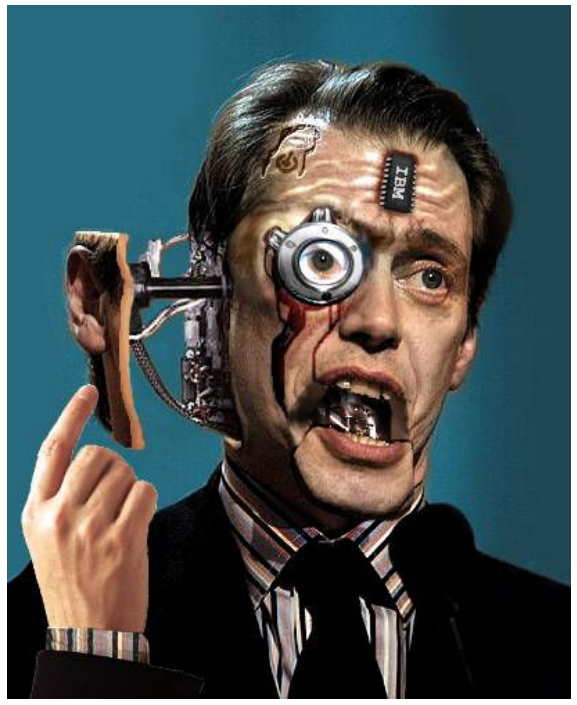

Imagem 17 - 0 ciborgue é uma mistura de realidade e ficção, propiciada pela engenharia genética. [é uma criatura de um mundo pós-gênero] (HARAWAY, 2009, p. 38)

http://www.google.com. br/images?q=fotos+de+ciborgues 
A autora - com seu Manifesto Ciborgue, o qual denomina "um esforço para construir um mito político, pleno de ironia, que seja fiel ao feminismo, ao socialismo e ao materialismo"207 - tem conseguido reconhecimento científico e traz uma contribuição fundamental para a comprovação das viabilidades do objeto central desta tese. A bióloga assume a mistura de ciência e política, fortalecida desde os anos 1970, quando obtinha seu doutorado na Universidade de Yale, nos EUA, e iniciava seu ativismo na luta pelos direitos gays e das mulheres. No Manifesto,

[...] a autora questiona o viés masculinista da cultura científica e vê a si própria como uma modesta e confusa testemunha da revolução ética trazida pela Engenharia Genética. Incapaz de silenciar sobre o que vê, Haraway, escrupulosamente, observa e registra. Ela se tornou uma heroína também para uma geração de mulheres que começam a chamar a si próprias de 'ciberfeministas'. ${ }^{208}$

Haraway (2009, p. 37-40) ${ }^{209}$ visualiza o caos provocado pela revolução das novas tecnologias como uma oportunidade transformadora da simbologia de gênero, além de enfatizar a estratégica oportunidade e necessidade nunca vistas na história "de unidade política, a fim de enfrentar de forma eficaz, as dominações de 'raça', de 'gênero', de 'sexualidade' e de 'classe'”:

[...] Este ensaio é um argumento em favor do prazer da confusão de fronteiras, bem como em favor da responsabilidade em sua construção. É também um esforço de contribuição para a teoria e para a cultura socialista-feminista, de uma forma pós-modernista, não naturalista, na tradição utópica de se imaginar um mundo sem gênero, que será talvez um mundo sem gênese, mas, talvez, também, um mundo sem fim.

\footnotetext{
${ }^{207}$ Ibidem. p.35

${ }^{208}$ KUNZRU, H. “Você é um ciborgue” - Um encontro com Donna Haraway. In: Antropologia do ciborgue As vertigens do pós-humano (Donna Haraway, Hari Kunzru e Tomaz Tadeu - org). Autêntica Editora Ltda. Belo Horizonte/MG. 2a .ed. 2009. p.21

${ }^{209}$ Ibidem. p.40
} 
[...] 0 ciborgue é uma criatura de um mundo pós-gênero. (...) 0 ciborgue não sonha com uma comunidade baseada no modelo de família orgânica mesmo que, desta vez, sem o projeto edípico. (...)

Neste momento, o percurso reflexivo sobre as instâncias teóricas e práticas desde o limiar desta tese, faz com que se depare com a imbricação de possibilidades de avanço na luta pela equidade das relações sociais de gênero, o que irá contribuir para mitigar uma das mais graves consequências que é a violência contra a mulher. 0 pensamento científico dos principais autores que embasam esta pesquisa para uma estratégia de comunicação a distância Habermas, Barbero, Paulo Freire e Castells - sintonizam-se com as inúmeras outras contribuições, quer no campo do feminismo quer na análise das nuances comunicacionais ensejadas pela era digital.

Da mesma forma, as considerações finais destacadas no próximo capítulo desta tese - em consonância com todo o percurso de uma pesquisa-ação refletem mais acentuadamente 0 desafio das dimensões éticas que a pressupõem. Em artigo publicado pela pesquisadora Kurtzman (2003) $)^{210}$, que é coordenadora geral da Aliança de pesquisa IREF/Relais-femme (ARIR) ${ }^{211}$, ela reconhece que "mesmo valorizando o saber do grupo, a pesquisadora, durante o processo, guarda o domínio da interpretação dos resultados”. Ao refletir sobre as inerentes relações de poder que atravessam também essa modalidade de pesquisa, Kurtzman (ibidem) sublinha algumas premissas com as quais esta doutoranda se identifica em todo o trajeto de seu trabalho:

[...] 0 poder que se encontra no cerne da reflexão da maior parte da produção escrita sobre Pesquisa-ação em geral e sobre a

\footnotetext{
${ }^{210}$ KURTZMAN, L. O desafio da ética na Pesquisa-ação feminista: uma experiência no Québec. Tradução: Tânia Navarro Swain. Montreal: Labrys, estudos feministas, número 3, janeiro/julho 2003. Disponível em: <http://www.tanianavarroswain.com.br/labrys/labrys3/web/bras/kurtzman1.htm>. Acesso: 10 Jan 2012.

${ }^{211}$ Trata-se de uma parceria de pesquisa entre o Institut de recherche et d'études féministes de l'UQAM e a organização Relais-femmes.
} 
pesquisa feminista em particular está, portanto, presente nas questões éticas da Pesquisa-ação feminista, que identifiquei e formulei da seguinte forma: inclusão das mulheres como verdadeiros sujeitos nos contextos de pesquisa; o reconhecimento e a integração de um saber fundamentado na ação; a construção de um processo democrático; o desenvolvimento de relações fundadas na confiança, respeito mútuo e empatia; o comprometimento da pesquisadora com relação à causa das mulheres. 
Considerações finais 
As comunidades femininas, bem como os espaços de liberdade da identidade sexual, projetam-se na sociedade como um todo ao minar o patriarcalismo e reconstruir a família a partir de uma base nova e igualitária, que implica o desaparecimento das relações marcadas pelo gênero nas instituições sociais, em oposição ao capitalismo e ao Estado patriarcais.

[...] É assim que a interação entre mudança estrutural e movimentos sociais - ou seja, entre a sociedade em rede e o poder da identidade - nos transforma. 
Nas páginas finais deste percurso que se mostra desafiador, porém, instigante, esta pesquisadora, embasada nas atividades práticas realizadas de forma dialógica e no aprofundamento teórico, volta à afirmação do objeto de estudo, consciente de sua potencialidade:

Na era digital, a comunicação a distância mostra-se como um caminho de reformulação da agenda feminista, balizada por novas estratégias de intervenção política e de atuação, levando em conta outras dinâmicas e a revolução das formas de expressão pessoal e interpessoal.

Neste momento, faz-se necessário ponderar que a nova identidade a ser plenamente conquistada pela mulher na era digital não submerge na humanidade para beneficiar a toda a sociedade em função única e exclusiva do advento das novas tecnologias da informação e comunicação, que têm na internet sua maior expressão. Sem dúvida, essa revolução tecnológica - além de inaugurar novas formas de transmissão da informação e do conhecimento - provoca diferentes noções temporais e espaciais, alterando a maneira de sentir, pensar e agir. Essas mudanças propiciam a construção de outras formas de expressão pessoal e interpessoal, resultando em narrativas inéditas por meio de outras dinâmicas comunicacionais. Por outro lado, há o acúmulo teórico e prático do movimento feminista e de mulheres de todo o mundo, exacerbado logo após a metade do século passado, levando ao momento atual de alteração nas estruturas da família patriarcal. Tal transformação é reconhecida, inclusive, por grandes homens cientistas, como Castells (1999, p. 173), para quem a mudança da sociedade resulta "da transformação da estrutura familiar e das normas sexuais uma vez que as famílias constituem o mecanismo básico de socialização e a sexualidade tem a ver com a personalidade", e como Giddens (1992), para quem "a democratização da vida pessoal é um processo menos visível, em parte justamente por não ocorrer na área pública, mas suas implicações são também muito profundas".

Obviamente, essa trajetória alicerça a reivindicação de uma nova identidade feminina, que pode ser impulsionada com ações de comunicação a 
distância, por meio das mídias digitais. De acordo com Castells (ibidem, p. 171173),

\begin{abstract}
[...] É preciso, também, considerar o momento da transformação. Por que justamente agora? As ideias feministas têm estado presente há pelo menos um século, se não mais, embora em versões históricas específicas. Por que pegaram fogo em nosso tempo? Sugiro a hipótese de que o motivo tem por base a combinação de quatro elementos: primeiro, a transformação da economia e do mercado de trabalho associada à abertura de oportunidades para as mulheres no campo da educação. [...] Em segundo lugar, vêm as transformações tecnológicas ocorridas na biologia, farmacologia e medicina, propiciando controle cada vez maior sobre a gravidez e a reprodução humanas. [...] Terceiro, tendo como pano de fundo a transformação econômica e tecnológica, o patriarcalismo [patriarcado] foi atingido pelo desenvolvimento do movimento feminista, conseqüência dos movimentos sociais da década de 60 . 0 quarto elemento a induzir o desafio ao patriarcalismo [patriarcado] é a rápida difusão de ideias em uma cultura globalizada, em um mundo interligado por onde pessoas e experiências passam e se misturam, tecendo rapidamente uma imensa colcha de retalhos formada por vozes femininas, estendendo-se sobre quase todo o planeta.

[...] É assim que a interação entre mudança estrutural e movimentos sociais - ou seja, entre a sociedade em rede e o poder da identidade - nos transforma.
\end{abstract}

Além desses dois autores que dão sustentação teórica a esta pesquisaação, neste momento de finalização da tese, faz-se importante percorrer o cerne do pensamento dos demais cientistas que propiciaram a ampliação dos horizontes da agenda feminista a partir da proposta de comunicação a distância. Ao descortinar as possibilidades estratégicas de impulsionamento da luta propiciadas pelas TIC, tais reflexões estiveram em coerência com as atividades realizadas de forma dialógica, pelo pressuposto da integração de saberes, levando em conta que "permite-se, na realidade, a inclusão de grupos de mulheres como sujeitos, facilitando a integração de seu saber específico na pesquisa e o desenvolvimento de relações fundadas na confiança, o respeito mútuo e a empatia." (KURTZMAN, 
$2003)^{212}$

Visando atingir - o tanto quanto possível - à precisão conceitual, no sentido de controlar a homogeneidade e a coerência na montagem da pesquisa, buscou-se um quadro teórico de referência desenvolvido a partir de algumas vertentes principais. A teorização para uma proposta de comunicação a distância levando em conta as possibilidades da era digital - que teve como pano de fundo duas oficinas de capacitação, sob o foco das TIC e da violência doméstica - foi alicerçada, desde o início, pelo potencial político transformador de Habermas, Martín-Barbero e Paulo Freire. Houve a busca do entendimento entre as participantes - o modo de agir em comum apregoado por Harbemas -, com a certeza de haver destinatários para a proposta aqui defendida, premissa básica de uma ação comunicativa. O mergulho nas teorias feministas e na questão da violência contra a mulher - um cruel fenômeno mundial que representa a mais forte expressão das desigualdades de gênero, o que requer o entrelaçamento de ações dos diversos segmentos, endossando, portanto, a relevância social desta tese -, ficou a cargo de estudiosas conceituadas como Saffioti, Blay, Scott, Jaggar e Bordo e Pimentel. A ponderação sobre o poder do imaginário na construção do pensamento e de práticas cotidianas foi profundamente respaldada por especialistas como Duran, Maffesoli, Bakhtin e Bosi. Outros autores deram sustentação às possibilidades potencializadas pelas novas formas de expressão e de transmissão da informação e do conhecimento principalmente pelos aspectos da interatividade e da produção colaborativa -, com uma ressonância mais potente de intervenção feminista por meio da comunicação a distância, propiciada pela revolução na esfera privada com papeis renegociados no seio da nova família não-patriarcal - como Citelli, Costa, Castells, Lévy, Di Felici e Haraway. Trata-se de delimitar, de acordo com Lévy (1996) o trajeto da comunicação um-todos, caracterizada pelas mídias

\footnotetext{
${ }^{212}$ KURTZMAN, L. O desafio da ética na Pesquisa-ação feminista: uma experiência no Québec. Tradução: Tânia Navarro Swain. Montreal: Labrys, estudos feministas, número 3, janeiro/julho 2003. Disponível em: <http://www.tanianavarroswain.com.br/labrys/labrys3/web/bras/kurtzman1.htm>. Acesso: 10 Jan 2012.
} 
analógicas, para o caminho que se descortina para a comunicação todos-todos, na era digital, simbolizada pelo axioma, pelo rizoma, isto é, “mapas cujos pontos se conectam de forma reversível: [...] um rizoma não começa nem conclui, ele se encontra sempre no meio, entre as coisas, inter-ser, intermezzo" (DELEUZE e GUATTARI, 2009, p. 37) 213

A maior parte dessas reflexões foi realizada depois de encerradas as oficinas de capacitação, atividades essas integrantes desta pesquisa-ação. Consciente de que não pode modificar a produção coletiva de um processo que não se encerrou, mas se deu por encerrado, coube a esta pesquisadora afastarse o máximo possível dessa vivência, para dirigir-lhe um olhar crítico. Daí ter havido a necessidade, para conclusões mais consistentes que levassem a um melhor entendimento das relações conceituais com o material produzido, de se alicerçar em um novo aprofundamento teórico, a partir das categorias já levantadas. Trata-se de um conhecimento complementar que irá contribuir para o processo das agentes multiplicadoras desta proposta de comunicação a distância, tendo em vista que esta pesquisadora irá disponibilizar esta tese, via comunicação a distância.

Como bem salienta Thiollent $(1998, \text { p. } 18)^{214}$, a metodologia de pesquisaação implica uma "relação obrigatória entre objetivos de pesquisa e objetivos de ação." Assim sendo, ela deve

[...] contribuir para o melhor equacionamento possível do problema considerado como central na pesquisa, com levantamento de soluções e propostas de ações correspondentes às 'soluções' para auxiliar o agente (ou ator) na sua atividade transformadora da situação.

Como se pode observar, as reflexões posteriores à experiência se enquadram em uma fase que propiciou o resgate conclusivo, requerendo $o$

\footnotetext{
${ }^{213}$ Ibidem. p. 37

214 Ibidem. p. 18
} 
retorno ao ponto de partida do objeto da pesquisa, passando pela dinâmica adotada para estar coerente com a afirmação do início deste capítulo. O endosso à afirmação que resume o objeto desta pesquisa-ação está fundamentado na trajetória dos planos teórico, metodológico, temático e prático. Da mesma forma, pode-se dizer que houve constatação das premissas que balizaram esta tese, que vão desde aquelas voltadas à revolução que representam as mídias digitais, trazendo consigo a revolução do aprendizado e das relações pessoais e interpessoais, reconfigurando a representação dos papeis da mulher no mundo por meio de novas narrativas; passando pela transformação do espaço privado, interferindo positivamente na problemática da violência doméstica; indo até a aposta de Castells no sentido de que a sociedade em rede e o fim do patriarcalismo levarão à transformação das relações entre mulheres e homens.

As pequenas ações desencadeadas por esse processo dialógico do saber se somam, fortalecendo o alcance do objetivo final, numa busca pela descaracterização do ativismo. O que se busca é estar impulsionada pelo aumento da consciência gerado a partir de um processo coletivo e interativo de conhecimento, sem deixar de considerar, conforme sublinhado por Jaggar e Bordo (1997, p. 58) que,

[...] a revolução permanente terá que ser uma revolução da incerteza, um desabrochar contínuo do desejo. Portanto, será inevitavelmente ambígua.

Registre-se, agora, outra consistente evidência desta tese, retratada pelas atividades de multiplicação realizadas pelas participantes junto aos oito grupos de base a que estão interligadas, durante o ano de 2010 e início de 2011. Tais experiências, mesmo que modestas, comprovam - tal como nas duas oficinas de capacitação objeto da pesquisa-ação - a adoção do exercício de novas narrativas, que se dão em forma de rede e pela interatividade, demonstrando que a comunicação a distância é uma estratégia potencial para novas formas de intervenção política e de atuação. O Anexo $D$ fornece os quadros com um resumo 
das atividades $^{215}$ realizadas pelas oito organizações locais nas quais as participantes atuam, indo da multiplicação de estratégias para o enfrentamento da tecnofobia, passando pelos domínios das fases de instrumentalização e produção, até a ressonância na potencialização da incidência na agenda feminista. Outro indicador é a ilustração de um relato de mudança significativa, ocorrida por ocasião da capacitação local realizada pela União de Mulheres de São Paulo. A data coincidiu com o período de grande repercussão do caso "Rodeio das Gordas"216. Indignadas com a violência praticada pelos estudantes, algumas participantes, utilizando um aparelho celular, gravam um vídeo de dois minutos, com opiniões a respeito. Postado no YouTube, o vídeo teve, em apenas dois dias, mais de 6 mil acessos (http: //www.youtube.com/user/ateliedemulheres\#p/u/41//mSial_DCgE), com opiniões qualificadas e sob a perspectiva das relações sociais de gênero.

Pode-se afirmar que, além do fato de essa experiência do projeto geral culminar com uma prática mais bem qualificada para o desafio da comunicação a distância por parte de todas as participantes de diferentes regiões brasileiras, esta pesquisa-ação provocou, de fato, uma transformação na agenda feminista, por meio da ressonância no movimento social. Um bom exemplo é o de um projeto envolvendo três das entidades parceiras participantes das atividades ora descritas: a Associação Mulheres pela Paz, juntamente com a Rede Mulher de Educação e o Geledés Instituto da Mulher Negra, além do Instituto Promundo que é uma ONG voltada para o trabalho de gênero com homens - e da União de Mulheres de São Paulo - uma das entidades de base participantes, implantou, em 2011, uma experiência com duração de dois anos, intitulada “Mulheres e

\footnotetext{
${ }^{215}$ Cada uma das organizações locais recebeu uma ajuda de custo no valor total de $\mathrm{R} \$ 4.575,00$ para a realização das atividades junto a seu público interconectando TIC e o foco da violência doméstica.

${ }^{216}$ Um grupo de alunos da Universidade Estadual Paulista (UNESP de Araraquara) organizou o "Rodeio das Gordas". Trata-se de uma "competição" em que um jovem tem como objetivo agarrar suas colegas, de preferências as obesas, e tentar simular um rodeio, ficando o maior tempo possível sobre a "presa". Primeiro, o estudante se aproxima da moça, como se estivesse jogando conversa fora. Faz perguntas como "onde você estuda?", "típicas" de paquera. Quando a "presa” está distraída, o “peão" salta em suas costas. Enquanto isso, os amigos cronometram o tempo em que o jovem fica em cima da aluna e gritam frases de "incentivo" como "Pula, gorda bandida!". A melhor performance era premiada com um abadá e uma caneca. (relato de Anna Frank, uma das participantes da oficina local).
} 
Homens pela Paz e contra a Violência Doméstica"217 (ver cartaz e folder no Anexo E), visando à construção de uma metodologia de educação popular feminista específica para trabalhar com ambos os sexos, por meio de oficinas de capacitação nas diferentes regiões brasileiras, reunindo lideranças governamentais e não-governamentais da rede de serviços contra a violência à mulher, que culminarão com atividades de comunicação a distância. Dentro de tais especificidades, pode-se afirmar que se trata de uma proposta inédita do movimento feminista e dos movimentos sociais brasileiros em geral. A imagem abaixo demonstra o paradigma que perpassa as ações em busca de um mundo com equidade de gênero:
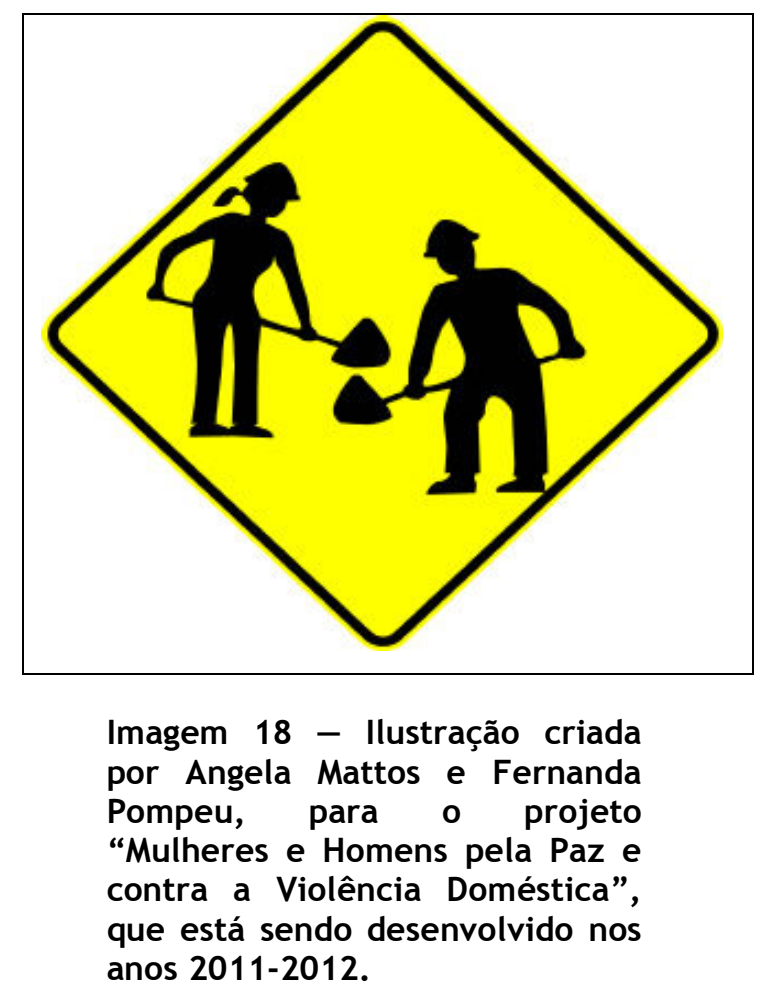

${ }^{217} \mathrm{O}$ caráter inovador e desafiante do projeto pode ser balizado pelo número de financiadoras internacionais e nacionais - EED (Alemanha), PWAG (Suíça), Vital Voices e NNEDV (EUA), Petrobrás, Secretaria de Políticas para Mulheres e Instituto Avon (Brasil). Outro indicador é o fato de o projeto ter sido selecionado para ser apresentado no $2^{\text {nd }}$ World Conference of Women's Shelters, em Washington-DC, no período de 27/2 a 1/3/2012, com a presença de cerca de 1400 pessoas de 95 países. 
E, para encerrar esta tese - sem deixar de novamente enfatizar as contribuições gestadas coletivamente nesta pesquisa-ação, as quais não se estabelecem como verdades absolutas -, enfatiza-se a reflexão de Citelli ${ }^{218}$, no sentido de que “[...] entre o 'aqui' e o 'lá', para retomarmos nossa tensão teórica de base, a semente pode frutificar; nos intervalos faíscas distribuem luzes e fazem das linguagens lugares de criação ideológica”, que é embalada pela frase de Paulo Freire $(1996, \text { p. } 85)^{219}$ já que “o mundo não é, o mundo está sendo".

\footnotetext{
${ }^{218}$ Ibidem. p. 60

${ }^{219}$ Ibidem. p. 85
} 


\section{GLOSSÁRIO}

Skype é um software que permite comunicação pela Internet através de conexões de voz sobre IP (VolP). Disponível em <pt.wikipedia.org>. Acesso: 10 Fev 2011.

Fórum de discussão é uma ferramenta para páginas de Internet destinada a promover debates através de mensagens publicadas abordando uma mesma questão. Também é chamado de "comunidade" ou "board". (ibidem)

Chat, que em português significa conversação, ou bate-papo (termo usado no Brasil), é um neologismo para designar aplicações de conversação em tempo real. Esta definição inclui programas de IRC, conversação em sítio web ou mensageiros instantâneos. (ibidem)

Videoconferência é uma tecnologia que permite o contacto visual e sonoro entre pessoas que estão em lugares diferentes, dando a sensação de que os interlocutores encontram-se no mesmo local. Permite não só a comunicação entre um grupo, mas também a comunicação pessoa-a-pessoa. (...) Atualmente, com o avanço dos processadores (cada vez mais rápidos) e a compressão de dados, surgiu um novo tipo de videoconferência, a conferência desktop. Nela não é necessário salas especiais e muito menos equipamentos ultra modernos: a interação é feita por uma webcam e um microfone simples. A compressão/descompressão e todo o resto são efetuados por software que deve estar instalado em uma máquina padrão. (ibidem) 


\section{REFERÊNCIAS BIBLIOGRÁFICAS ${ }^{220}$}

ALMEIDA in VIEIRA et al., 2002. Pesquisa integrada: aspectos que orientam o desenvolvimento de ambientes virtuais (IX Congresso Internacional de EaD/ABED).

ALMEIDA. T. M. C. A. As raízes da violência na sociedade patriarcal. Sociedade e Estado. Vol.19. no 1. Brasília. Jan/Jun/2004. (também disponível em www.scielo.br)

ALVES, L. R. Ciência e mito na gestão internacional. INTERNEXT - Revista Eletrônica de Negócios Internacionais da ESPM, São Paulo, v. 2, n. 1, jan./jun. 2007, p.46. Também disponível em <http://internext.espm.br/index.php/internext/article/viewFile/17/16>. Acesso: 10 Dez 2011.

ANDERSON, J. Sistemas de gênero, redes de atores e uma proposta de formação. Tradução: Beatriz Cannabrava. REPEM/CEAAL. Uruguai. 1997 ANDERSON, J. Sistemas de gênero, redes de atores e uma proposta de formação. Tradução: Beatriz Cannabrava. REPEM/CEAAL. Uruguai. 1997

BACCEGA, M. A. Comunicação: interação emissão/recepção. In: Revista Comunicação e Educação. no.23. ECA-USP/Ed.Salesiana. jan-abr/2002.

A. A construção do campo comunicação/educação: alguns caminhos. In: Revista USP. no.48. dez-jan-fev/2000-2001.

BAKHTIN, Mikhail. Marxismo e filosofia da linguagem. Tradução: Michel Lahud e Yara Frateschi Oliveira. SP: Editora Hucitec. 1999

BLAY, E. A. Violência contra a mulher e políticas públicas - Estudos Avançados - Print version ISSN 0103-4014. Estud. av. vol.17. no.49. SP. set-dez/2003. Também disponível em <http://www.scielo.br /scielo.php?script=sci_arttext\&pid=S010340142003000300006) > Acesso: 20 set 2011.

Violência contra a mulher e políticas públicas - Estudos Avançados - Print version ISSN 0103-4014. Estud. av. vol.17. no.49. SP. set-dez/2003). Também disponível em

<http: / / www.scielo.br/scielo.php?script=sci_arttext\&pid=S010340142003000300006>. Acesso: 20 set 2011.

BOURDIEU, P. A dominação masculina. Ed.Bertrand. Brasil. 1999

BOSI, E. Entre a opinião e o estereótipo. In: O tempo vivo da memória - Ensaios de Psicologia Social. Ateliê Editorial. SP: 2004. $2^{\mathrm{a}}$ ed.

CALABRE, L. Nos tempos da radionovela. Comunicação \& Sociedade, São Bernardo do Campo, PósCom-Metodista, a. 29, n. 49, p. 65-83, $2^{\circ}$ sem. 2007. e disponível em: <http://pt.wikipedia.org/wiki/Radionovela>. Acesso em: 30 set. 2011

${ }^{220}$ De acordo com a Associação Brasileira de Normas Técnicas. NBR 6023. 
CARREIRA, D.; AJAMIL, M.; MOREIRA. T. (org). A liderança feminina no século 21. SP: Coedição: Cortez e Rede Mulher. 2001.

CASTELLS, M. Tradução: Klaus Brandini Gerhardt. O poder da identidade. SP: Paz e Terra, $1999,6^{\text {a }}$ ed

CITELLI, Adilson Odair. Comunicação e Educação. A linguagem em movimento. $3^{\text {a }}$ ed. SP: Senac. 2004

COSTA, A.A.A. Trajetória e Perspectivas do Feminismo para o Próximo Milênio. In: Metamorfoses - Gênero na perspectiva interdisciplinar. Salvador: UFBA, Núcleo de Estudos Interdisciplinares sobre a mulher. 1998.

COSTA, C. A imagem da mulher: um estudo de arte brasileira. RJ: Senac Rio. 2002.

Interatividade - entre graus de liberdade e intencionalidades narrativas. p.

3. Também disponível em: <www.intercom.org.br>. Acesso em: 23 abr. 2011

DELEUZE, G.; GUATTARI, F. Mil Platôs Capitalismo e Esquizofrenia. Volume 1. Tradução: Aurélio Guerra Neto e Célia Pinto Costa. Editora 34. SP: 2009 (6 $6^{\mathrm{a}}$ reimpressão)

DI FELICE. M. Das tecnologias da democracia para as tecnologias da colaboração. In: Do público para as redes - A comunicação digital e as novas formas de participação social. (org: o próprio). São Caetano do Sul/SP. Difusão Editora. 2008

DIZARD JR., W. A nova mídia - a comunicação de massa na era da informação. Tradução: Antonio Queiroga e Edmond Jorge. SP: Jorge Zahar Editor. 2000.

DORFMANN, P. F. Atributos favoráveis à motivação para visitação de um site: estudo de um portal educacional. 2003. 93p. Dissertação (Mestrado em Administração). Escola de Administração. PPGO, UFRGS. Porto Alegre. 2003

DOWNING, J. D. H. Revista Matrizes, volume 3, no.2, 2010. Também disponível em: <http://www.matrizes.usp.br>. Acesso em 30 set. 2011

DUBY, G. Idade Média, Idade dos Homens - do amor e outros ensaios. Tradução: Jônatas Batista Neto. São Paulo: Companhia das Letras, 1989.

Damas do Século XII - A Lembrança das Ancestrais. Tradução: Maria Lúcia Machado. São Paulo: Companhia das Letras, 1997,

DURAND, G. As estruturas antropológicas do imaginário. Tradução: Hélder Godinho. SP: Martins Fontes. $2^{\text {a }}$ ed. 2001.

O imaginário - ensaio acerca das ciências e da filosofia da imagem. Tradução: René Eve Levié. RJ: Difel. $2^{\mathrm{a}}$ ed. 2001

FAGUNDES, T.C.P.C. Educação e Construção da Identidade de Gênero. In: Ensaios sobre Gênero e Educação. (org. pela mesma). Salvador: UFBA, 2001.

FESTA, R. Notas para um novo milênio: questões de gênero e sistemas de comunicação e 
informação. In: Perspectivas de gênero - debates e questões para as Ongs. Recife. GT Gênero - Plataforma de contrapartes Novib / SOS Corpo. 2001

FREIRE, N. Onde tem violência, todo mundo perde. Folha de S. Paulo. SP. 06/08/2006

FREIRE, P. Extensão ou Comunicação? Tradução: Rosisca Darcy de Oliveira. SP. Paz e Terra. $2^{\mathrm{a}} \mathrm{Ed}$

Pedagogia da Autonomia - Saberes necessários à prática educativa. SP: Paz e Terra. $20^{a}$.edição. 1996

Pedagogia da Esperança - um reencontro com a Pedagogia do Oprimido. RJ: Paz e Terra. $7^{\text {a ed. }} 2000$

Pedagogia do Oprimido. SP: Paz e Terra. $15^{\mathrm{a}}$ ed. 1983

FREIRE, P.; GUIMARÃES, S. Aprendendo com a própria história II. São Paulo: Paz e Terra, 2000,

GIDDENS, A. A transformação da intimidade. Tradução: Magda Lopes. São Paulo: Ed. UNESP, 1993

HABERMAS, J. Consciência moral e agir comunicativo. Tradução: Guido Antônio de Almeida. RJ: Ed. Tempo Brasileiro. 1989.

Edições Tempo Brasileiro. 1984.

Mudança estrutural da esfera pública. Tradução: Flávio R.Kothe. RJ:

HARAWAY, D. Manifesto ciborgue- Ciência, tecnologia e femiismo-socialista no final do século XX. In: Antropologia do ciborgue - As vertigens do pós-humano (Donna Haraway, Hari Kunzru e Tomaz Tadeu - org). Autêntica Editora Ltda. Belo Horizonte/MG. $2^{\text {a }}$.ed. 2009.

HOBSBAWM, E. Era dos extremos - o breve século XX - 1914-1991. Tradução: Marcos Santarrita. $2^{\text {a }}$ Ed., SP: Cia. das Letras, 1995

JAGGAR, A.M.; BORDO, S.R. Gênero, Corpo, Conhecimento. Tradução: Britta Lemos de Freitas. Rio de Janeiro: Ed. Rosa dos Tempos, 1997

KUNZRU, H. "Você é um ciborgue" - Um encontro com Donna Haraway. In: Antropologia do ciborgue - As vertigens do pós-humano (Donna Haraway, Hari Kunzru e Tomaz Tadeu org). Autêntica Editora Ltda. Belo Horizonte/MG. 2a .ed. 2009

KURTZMAN, L. O desafio da ética na Pesquisa-ação feminista: uma experiência no Québec. Tradução: Tânia Navarro Swain. Montreal: Labrys, estudos feministas, número 3, janeiro/julho 2003. Também disponível em:

<http://www.tanianavarroswain.com.br/labrys/labrys3/web/bras/kurtzman1.htm>. Acesso: 10 Jan 2012.

LAQUEUR, T. Inventando o Sexo - Corpo e gênero dos gregos a Freud. RJ: Ed. Relume Dumará, 2001 
LEVY, C. Influência e contribuição: a igreja católica progressista brasileira e o fórum social mundial. RJ: Relig. soc. Volume 29. $\mathrm{n}^{\circ}$. 2. Também disponível em <http://www.scielo.br/scielo.php?script=sci_arttext\&pid=S010085872009000200009\&lng=pt\&nrm=iso>. Acesso: 10 Out 2011.

LÉVY, P. O que é o virtual? Tradução de Paulo Neves. $7^{\text {a }}$ ed., SP: Editora 34. 1996

LINS, J. W. Resenha de "A imagem da mulher: um estudo de arte brasileira" de Cristina Costa. Revista Estudos Feministas, RJ. UFRJ. Jan-Abr., ano/vol.12, número 001. 2004. Disponível também em: <http://redalyc.uaemex.mx/pdf/381/38112121.pdf>. Acesso em: 14 abr. 2011.

LOPES, M. I. V. Pesquisa em Comunicação. SP: Loyola. $3^{\text {aed. } 1997}$

MAFFESOLI, M. O imaginário é uma realidade. Entrevista à Revista Famecos. Porto Alegre. no.15. agosto/2001

MARTIN-BARBERO, J. Heredando el futuro. Pensar la educacion desde la comunicacion. In Revista Nómadas. S/d

Ed. UFRJ. 1997

Dos meios as mediações - comunicação, cultura e hegemonia. RJ:

Entre urbanias e cidadanias. In. Cartografias Culturais da sensibilidade e da tecnicidade (apostila). Bogotá: Junho/2006.

Narrativas estalladas - entre oralidades recuperadas y visualidades hegemônicas. Palestra apresentada no Congresso Latinoamericano de Jalla, Bogotá, 2006, en prensa. (disponível na apostila Cartografias culturales de la sensibilidad y la tecnicidad, distribuída por ocasião das aulas ministradas na USP/ECA, no período de 15-19/9/2008.

MATTELART, Armand e Michèle. História das teorias da comunicação. Tradução: Luiz Paulo Rouanet. SP: Edições Loyola. $2^{\mathrm{a}}$ ed. 1999.

MATUTE, A. El metodo de acercamiento crítico. La calidad en el proceso educativo. In: Educacion para la comunicacion - manual latinoamericano de educación para los medios de comunicación. Chile. Ceneca, Unesco e Unicef. 1992

MELO, E.; FREITAS, J.M.; FERREIRA, V.M. Representações de Gênero - Abordagem Histórica. In: Ensaios sobre gênero e educação. FAGUNDES, T.C.P.C. Salvador: UFBA Pró-Reitoria de Extensão, 2001.

MELO, J. IRACI, N. VIEIRA, V. Fazendo Lobby - Guia para a participação de delegados/as no processo de negociação na $1^{a}$ Conferência Nacional de Comunicação (Confecom). SP. Rede Mulher. 2009

MOLYNEUX, M. Movimento de Mulheres. In. Dicionário do pensamento social do século XX. Edição de William Outhwaite \& Tom Bottomore. RJ. Jorge Zahar Editor. 1996 
MORAN, J. M. Como utilizar a internet na educação. Também disponível em: <www.scielo.br>. Acesso em: 30 set. 2011.

OROZCO, G. La investigación en comunicación desde la perspectiva cualitativa. Guadalajara/México. Facultad de Periodismo y Comunicación Social, Universidade de la Plata \& IMDEC (Instituto Mexicano para el Desarrollo Comunitario, A.C.). $2^{\text {a }}$ ed. 1997

PACHECO, E. D. LAPIC: espaço lúdico de conhecimento sobre TV/criança. In: Revista Comunicação e Educação. no.19. SP. ECA-USP/Editora Segmento. 2000

PIOVESAN, F.; PIMENTEL, S. Mulher, Democracia e Desenvolvimento. São Paulo: Folha de S.Paulo. Tendências. 9/1/2011.

PLOU, D.; VIEIRA, V. Mulher e Tecnologias: a virtualidade como espaço transformador das relações de gênero. São Paulo: Rede Mulher, 2007

REPEM. Educação popular e liderança das mulheres na construção da democracia latinoamericana. Quito/Equador. set/90

SAFFIOTI, H. O poder do macho. Editora Moderna. SP. 1987

2004

Gênero, Patriarcado, Violência. Editora Fundação Perseu Abramo. SP:

SANTAELLA, L. Linguagens líquidas na era da mobilidade. São Paulo: Paulus, 2007

SCHUMAHER, S.; BRAZIL, E. V. Dicionário Mulheres do Brasil - de 1500 até a atualidade. RJ: Jorge Zahar Editor. 2000.

SCOTT, J. W. "Gênero: uma categoria útil de análise histórica". Educação \& Realidade. Porto Alegre, vol. 20, n²,jul./dez. 1995,

SILVA, C. Histórias híbridas de uma senhora de respeito, SP: Editora Braziliense, 1984.

SILVERSTONE, R. Por que estudar a mídia? Tradução: Milton Camargo Mota. Edições Loyola. SP. 2a . ed. 2005.

SOARES, I. O. O campo da Comunicação/Educação, suas subáreas e a emergência de um novo espaço profissional. Pesquisa do Núcleo de Comunicação e Educação da Escola de Comunicações e Artes da Universidade de São Paulo (NCE/ECA/USP). 1998. SP.

TAVARES, R. R. Basta à violência contra as mulheres. Folha de S.Paulo. SP. 16/07/10

TELES, M.A.A.; MELO, M. O que é violência contra a mulher. São Paulo: Ed.Brasiliense, 2002.

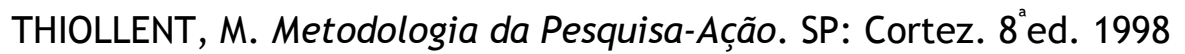

TORRES, J. C. Cyborgcracia: entre a gestão digital dos territórios e as redes sociais digitais. In: Do público para as redes - A comunicação digital e as novas formas de participação social (org: Massimo Di Felice). Difusão Editora. São Caetano do Sul/SP. 
2008.

VATTIMO, Gianni. A sociedade transparente. Relógio d’Água Editores Ltda. Lisboa: 1992

VIEZZER, M. Paulo Freire e as Relações Sociais de Gênero. Informativo Cunhary/Rede Mulher. SP. no.24. jul-ag/97.

WILLIAMS, R. Cultura. São Paulo: Paz e Terra. 1992.

\section{SITIOGRAFIA}

<www.invivo.fiocruz.br/cgi>. Acesso: 8 Dez 2011

<http://www.direitoshumanos.usp.br/index.php/Documentos-anteriores-\%C3\%A0cria\%C3\%A 7\%C3\%A3o-da-Sociedade-das-Na\%C3\%A7\%C3\%B5es-at\%C3\%A9-1919/declaracaodos-direitos-da-mulher-e-da-cidada-1791.html>. Acesso em: 10 out. 2011.

<pt.wikipedia.org/wiki/Pagu>. Acesso em: 14 abr 2011

<www.wikipedia.com> e <www.adorocinema.com/filmes>. Acesso em: 23 abr. 2011. <http://pt.wikipedia.org/wiki/Leila_Diniz>. Acesso em: 17 abr. 2011

<http//www.tudosobretv.com.br>. Acesso: 17 abr. 2011

<http://www.ibdfam.org.br/>. Acesso em: 23 abr. 2011

<http://pt.wikipedia.org/wiki/TV_Mulher >. Acesso em: 23 abr. 2011

<http://pt.wikipedia.org/wiki/Senhoras_de_Santana>. Acesso em: 23 abr. 2011

<www.redemulher.org.br>. Acesso em 23 abr. 2011

<http://www.ciberespaco.com.br/index.php?title=Das_cavernas_\%C3\%A0_aldeia_global> Acesso: 10 Abr 2011.

<http://pt.wikipedia.org/wiki/Guglielmo_Marconi>. Acesso em: 20 set. 2011.

<http://www.teleco.com.br/rtv.asp>. Acesso em: 14 out. 2011

<http://www1.folha.uol.com.br/folha/dinheiro/ult91u105765.shtml>. Acesso em 20 set. 2011

<www.bandalarga.org.br>. Acesso: 12 set. 2011.

<http: / /www.genderit.org/es/feminist-talk/estreita-vis-o-da-banda-larga-no-brasil>. Acesso em: 2 ago. 2011. 
<www.bandalarga.org.br>. Acesso: 12 set. 2011.

<pt.wikipedia.org>. Acesso em: 30 set. 2011.

<http://www.archive.org/details/scott_gender>. Acesso: 27 out. 2011

<http://www.archive.org/details/scott_gender>. Acesso: 27 out. 2011

<http://www.ibge.gov.br/paisesat/>. Acesso em 10 jul. 2011.

<http://www.sepm.gov.br/noticias/ultimas_noticias/2010/10/onu-divulga-relatoriosobre-a-situacao-das-mulheres-no-mundo>. Acesso: 20 out. 2011.

<http://cordelirando.blogspot.com/2010/07/o-caso-eliza-samudio-e-o-machismototal.html> Acesso em 10 Jul 2011.

<http://www.weforum.org/issues/global-gender-gap>. Acesso em: 10 nov. 2011.

<http://www.censo2010.ibge.gov.br/>. Acesso: 17 nov 2011

<http: / / www.mcphearsonreport.com/1999/12/breast-rugby-soccer-and-abortion-theoppressive-connection/>. Acesso: 17 nov 2011

<http://www.cfemea.org.br/publicacoes/artigos_detalhes.asp?IDArtigo=3>

<http://pt.wikipedia.org/wiki/Sufr\%C3\%A1gio_feminino>. Acesso: 10 Mar 2011.

<http://g1.globo.com/mundo/noticia/2011/08/washington-tem-marcha-das-vadiascontra-violencia-sexual.html> Acesso: 10 Out 2011.

<http://200.130.7.5/spmu/docs/pesq_Violencia\%20contra\%20a\%20mulher.pdf>. Acesso em 30 set. 2011

<www.soscorpo.org.br>. Acesso em: 30 set. 2011.

<http://www.institutosangari.org.br/mapadaviolencia/>. Acesso em: 30 set. 2011

<http://www.ciranda.net>. Acesso em: 30 set. 2011.

<www.globalvoices.org>. Acesso em: 30 set. 2011.

<www.unifem.org.br>. Acesso: 10 Nov 2011.

<http://www.unifem.org.br/ 005/00502001.asp?ttCD_CHAVE=8466>. Acesso: 20 nov 2011.

<http://pt.wikipedia.org/wiki/Cepal>. Acesso em: 30 set. 2011).

<www.cepal.org/mujer/conferencia/doc/ConsensoBrasilia>. Acesso em: 30 set. 2011.

<http://www.feminismo.org.br/livre/index.php?option=com_content\&view=article\&id=4 645: tipificacao-dofeminicidio\&tatid=58:violencia\&t|temid=386>. Acesso: 20 nov 2011. 
<http://www.tvmagazine.com.br/blogs/post.asp?ID=1874>. Acesso: 22 maio 2011.

Disponível em <http://www.planalto.gov.br/ccivil_03/_ato20042006/2006/lei/l11340.htm> Acesso: 5 Fev 2011.

<http://www.tvmagazine.com.br/blogs/post.asp?ID=1874>. Acesso: 20 nov. 2011

<http://especial. viveravida.globo.com/portal-da-superacao/>. Acesso: 20 set 2011.

<www.violenciamulher. org.br>. Acesso: 5 mar 2011.

<http://pt.wikipedia.org/wiki/Doca_Street>. Acesso: 22 mai 2011.

<http: / / www.iwhc.org/index.php?option=comcontent\&task=view\&id=2967\&ltemid=323>

. Acesso: 22 mai 2011

<www.agende.org.br>. Acesso: 10 mai 2011

<www.bbc.co.uk/tellinglives> Acesso: 5 jun 2010.

<http://digitalstorytelling.coe.uh.edu/>. Acesso: 25 abr 2010

$<$ www.microsoft.com/education/en-us/.../digital_storytelling.aspx>. Acesso: $25 \mathrm{abr}$ 2010.

<http://ogestor.wordpress.com/2009/08/03/tecnofobia-saiba-o-que-e/>. Acesso: 10 out 2010

<http://www.youtube.com/results?search_query=depoimento+de+vera+vieira>. Acesso: 10 out 2010.

<http://revistaepoca.globo.com/Revista/Epoca/0, EMI204306- 15227,00.html>. Acesso: 12 Dez 2011.

<http://ultimosegundo.ig.com.br/mundo/em+novo+dia+de+protestos+egito+estende+to que+de+recolher/n1237974293540.html> Acesso em: 10 nov 2011.

<http://pt.wikipedia.org/wiki/Axioma>. Acesso: 10 Fev 2011.

<http://www.youtube.com/user/ateliedemulheres\#p/u/41//mSial_DCgE>. Acesso: 10 Fev 2011. 
Anexos 


\section{ANEXO A - Usuários de internet no Brasil \\ (http://www.teleco.com.br/internet.asp)}

\section{Usuários de Internet no Brasil}

Apresenta-se a seguir a quantidade de usuários de Internet no Brasil de acordo com várias Fontes.

\begin{tabular}{|l|c|c|c|c|c|c|c|}
\hline \multicolumn{1}{|c|}{ Milhões } & $\mathbf{2 0 0 5}$ & $\mathbf{2 0 0 6}$ & $\mathbf{2 0 0 7}$ & $\mathbf{2 0 0 8}$ & $\mathbf{2 0 0 9}$ & $\mathbf{2 0 1 0}$ & $\mathbf{2 0 1 1}$ \\
\hline Fonte: PNAD & 32,0 & 35,3 & 44,9 & 55,9 & 67,9 & N.D. & N.D. \\
\hline Fonte: $\underline{\text { TIC Domicílios }}$ & - & 35,3 & 44,9 & 53,9 & 63 & N.D. & N.D. \\
\hline Fonte Ibope* & - & 32,5 & 39 & 62,3 & 67,5 & 73,9 & $78,5 * *$ \\
\hline
\end{tabular}

Dados do PNAD e TIC Domicílios, referentes a população de 10 anos ou mais de idade que acessou a Internet, pelo menos uma vez, nos 90 dias que antecederam à entrevista.

* Total de pessoas com com mais de 16 anos com acesso à internet em qualquer ambiente.

**Valor referente ao 3T11.

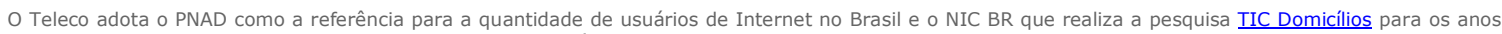
de 2006 e 2007, quando os dados do PNAD não estão disponíveis.

\section{3 milhões de usuários de Internet em Mai/10 (Comscore)}

Segundo dados da ComScore existiam 73 milhões de usuários de Internet no Brasil em Mai/10. A pesquisa abrange um universo maior que as demais incluindo pessoas a partir de 6 anos de idade. Destes, 40,7 estiveram ativos em maio de 2010, sendo 11,9\% com idade entre 6 e 14 anos e $56,1 \%$ com idade entre 15 e 34 anos. 


\begin{tabular}{|c|c|c|}
\hline Milhares & Usuários ativos & Pessoas com acesso \\
\hline Mar/09 & 25.457 & 38.231 \\
\hline Jun/09 & 33.166 & 44.452 \\
\hline Set/09 & 35.503 & 46.646 \\
\hline Dez/09 & 36.577 & 46.804 \\
\hline $\mathrm{Jan} / 10$ & 36.858 & 46.804 \\
\hline $\mathrm{Fev} / 10$ & 36.701 & 46.986 \\
\hline Mar/10 & 37.925 & 46.986 \\
\hline $\mathrm{Abr} / 10$ & 36.636 & 46.986 \\
\hline Mai/10 & 37.282 & 46.986 \\
\hline Jun/10 & 39.907 & 48.703 \\
\hline $\mathrm{Jul} / 10$ & 39.258 & 48.703 \\
\hline Ago/10 & 41.566 & 51.827 \\
\hline Set/10 & 40.564 & 51.827 \\
\hline Out/10 & 41.700 & 51.827 \\
\hline Nov/10 & 43.592 & 54.523 \\
\hline Dez/10 & 43.313 & 54.523 \\
\hline Jan/11 & 42.757 & 54.523 \\
\hline $\mathrm{Fev} / 11$ & 41.361 & 56.016 \\
\hline Mar/11 & 43.187 & 56.016 \\
\hline Abr/11 & 42.792 & 56.016 \\
\hline Mai/11 & 45.681 & 58.637 \\
\hline Jun/11 & 45.556 & 58.637 \\
\hline $\mathrm{Jul} / 11$ & 44.883 & 58.637 \\
\hline
\end{tabular}




\begin{tabular}{|c|c|c|}
\hline Ago/11 & 45.404 & 61.195 \\
\hline Set/11 & 46.307 & 61.195 \\
\hline Out $/ 11$ & 46.694 & 61.195 \\
\hline Nov/11 & 47.963 & 63.466 \\
\hline Dez/11 & 46.589 & 63.466 \\
\hline
\end{tabular}

\section{Usuários Domiciliares de Internet}

O IBOPE/Net ratings acompanha o número de usuários domiciliares de Internet no Brasil. A tabela a seguir apresenta o acompanhamento destes dados.

O número de usuários ativos em Mar/11 foi de 35,1 milhões (IBOPE Nilesen Online). A tabela a seguir apresenta a distribuição de usuários por velocidade.

\begin{tabular}{|l|c|c|}
\hline Velocidade de usuários ativos & Set/10 & Set/11 \\
\hline até 128 kbps & $11,3 \%$ & $4,2 \%$ \\
\hline \hline 128 a 512 kbps & $26,7 \%$ & $16,9 \%$ \\
\hline 512 kbps a 2 Mb & & \\
\hline & $44,7 \%$ & $47,8 \%$ \\
\hline Mb a 8 Mb & $12,1 \%$ & $21,3 \%$ \\
\hline acima de 8 Mb & & $8,7 \%$ \\
\hline Não identificado & $1,0 \%$ & $1,1 \%$ \\
\hline Total & 31.818 & 37.857 \\
\hline
\end{tabular}

Usuários ativos no mês

\begin{tabular}{|c|c|c|c|c|}
\hline Milhares & $\mathbf{2 0 0 6}$ & $\mathbf{2 0 0 7}$ & $\mathbf{2 0 0 8}$ & $\mathbf{2 0 0 9}$ \\
\hline Janeiro & 12.036 & 14.034 & 21.100 & 24.467 \\
\hline Fevereiro & 13.241 & 14.068 & 22.043 & 24.806 \\
\hline Março & 14.107 & 16.257 & 22.742 & 25.457 \\
\hline
\end{tabular}




\begin{tabular}{|c|c|c|c|c|}
\hline Abril & 13.431 & 15.867 & 22.419 & 25.460 \\
\hline Maio & 13.246 & 17.933 & 23.141 & 25.566 \\
\hline Junho & 13.397 & 18.047 & 22.910 & 25.600 \\
\hline Julho & 13.393 & 18.523 & 23.715 & 27.500 \\
\hline Agosto & 13.641 & 19.302 & 24.331 & 28.977 \\
\hline Setembro & 13.639 & 20.100 & 24.407 & - \\
\hline Outubro & 13.313 & 19.881 & 23.676 & - \\
\hline Novembro & 14.448 & 21.536 & 24.419 & - \\
\hline Dezembro & 14.419 & 21.393 & 24.545 & 28.500 \\
\hline
\end{tabular}

Fonte: IBOPE NetRatings

Nota: Em Jan/10 o IBOPE não divulgou o número de usuários domiciliares de Internet.

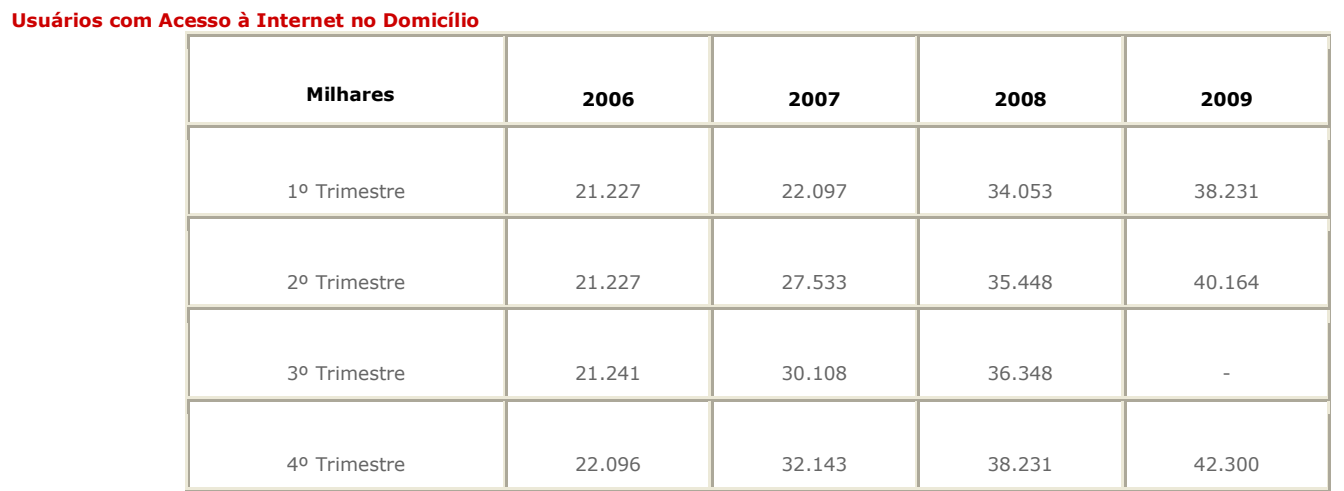

Fonte: IBOPE NetRatings

Segundo esta pesquisa em dezembro de 2005 existiam 18,9 milhões de usuários com acesso em suas residências, sendo que 12,2 milhões haviam efetivamente acessado a Internet em dezembro de 2005.

Usuários residenciais com Banda Larga (milhares)

\begin{tabular}{|c|c|c|}
\hline Milhares & Usuários ativos & Usuários com acesso \\
\hline Fev/09 & & 29.077 \\
\hline
\end{tabular}




\begin{tabular}{|c|c|c|}
\hline Jan/09 & 20.706 & 28.324 \\
\hline Abr/08 & 18.300 & ND \\
\hline Fev/08 & 17.414 & 23.623 \\
\hline Set/07 & 15.400 & ND \\
\hline Abr/07 & & ND \\
\hline Set/06 & 11.900 & ND \\
\hline
\end{tabular}

Fonte: IBOPE NetRatings

\section{Domínios}

\begin{tabular}{|c|c|c|c|c|c|c|}
\hline \multicolumn{7}{|c|}{ Quantidade de Domínios } \\
\hline Milhares & 2006 & 2007 & 2008 & 2009 & 2010 & 2011 \\
\hline Jan & 867 & 1.037 & 1.241 & 1.553 & 1.965 & 2.350 \\
\hline Fev & 881 & 1.053 & 1.251 & 1.572 & 1.986 & 2.368 \\
\hline Mar & 899 & 1.074 & 1.274 & 1.608 & 2.023 & 2.410 \\
\hline $\mathrm{Abr}$ & 912 & 1.090 & 1.298 & 1.653 & 2.065 & 2.462 \\
\hline Mai & 928 & 1.114 & 1.342 & 1.691 & 2.107 & 2.499 \\
\hline Jun & 944 & 1.135 & 1.375 & 1.725 & 2.135 & 2.545 \\
\hline Jul & 958 & 1.152 & 1.416 & 1.771 & 2.172 & 2.590 \\
\hline Ago & 978 & 1.174 & 1.449 & 1.808 & 2.204 & 2.625 \\
\hline Set & 991 & 1.193 & 1.473 & 1.844 & 2.236 & 2.655 \\
\hline Out & 1.006 & 1.212 & 1.498 & 1.904 & 2.275 & 2.698 \\
\hline Nov & 1.021 & 1.226 & 1.527 & 1.941 & 2.299 & 2.725 \\
\hline Dez & 1.025 & 1.231 & 1.534 & 1.953 & 2.318 & 2.740 \\
\hline
\end{tabular}


Hosts

\begin{tabular}{|l|c|c|c|c|c|c|c|c|c|c|}
\hline Milhares & $\mathbf{2 0 0 0}$ & $\mathbf{2 0 0 1}$ & $\mathbf{2 0 0 2}$ & $\mathbf{2 0 0 3}$ & $\mathbf{2 0 0 4}$ & $\mathbf{2 0 0 5}$ & $\mathbf{2 0 0 6}$ & $\mathbf{2 0 0 7}$ & $\mathbf{2 0 0 8}$ & $\mathbf{2 0 0 9}$ \\
\hline Domínios & 360 & 448 & 413 & 539 & 709 & 859 & 1.025 & 1.231 & 1.534 & 1.953 \\
\hline
\end{tabular}

\begin{tabular}{|l|c|c|c|c|c|c|c|c|c|c|c|c|}
\hline Milhares & $\mathbf{2 0 0 0}$ & $\mathbf{2 0 0 1}$ & $\mathbf{2 0 0 2}$ & $\mathbf{2 0 0 3}$ & $\mathbf{2 0 0 4}$ & $\mathbf{2 0 0 5}$ & $\mathbf{2 0 0 6}$ & $\mathbf{2 0 0 7}$ & $\mathbf{2 0 0 8}$ & $\mathbf{2 0 0 9}$ & $\mathbf{2 0 1 0}$ & $\mathbf{2 0 1 1 *}$ \\
\hline Hosts & 877 & 1.645 & 2.238 & 3.163 & 3.935 & 5.095 & 7.422 & 10.152 & 14.679 & 17.787 & 21.121 & 22.212 \\
\hline
\end{tabular}




\section{ANEXO B - Resumo da Confecom}

(www.apc.org)

Realizada em Brasília, no período de 14 a 17 de dezembro de 2009, a $1^{\text {a }}$ Conferência Nacional de Comunicação (Confecom) - Comunicação: meios para construção de direitos e de cidadania na era digital reuniu quase 2 mil pessoas (1684 delegados/as - sendo 40\% do empresariado, $40 \%$ da sociedade civil organizada e $20 \%$ do governo -, além de 300 observadores/as), dos 26 estados e distrito federal. Aprovou um total de 672 propostas, depois da análise em 15 grupos temáticos, sendo 601 aprovadas nos grupos com mais de $80 \%$ dos votos e 71 em plenária final. Antes de tudo, a $1^{\text {a }}$ Confecom deve ser celebrada por se tratar de um fato inédito em toda a história brasileira. Além disso, trata-se de um evento da maior importância para o avanço do processo democrático, que inclui o direito à comunicação, especialmente na era das novas tecnologias da informação e comunicação, considerando-se que a exclusão digital caminha paralelamente à exclusão social. A conferência teve três eixos temáticos: I- Produção de conteúdo, II- Meios de distribuição e III- Cidadania, direitos e deveres (ver detalhes no Box 1). As principais discussões estiveram focadas na regulamentação dos sistemas de comunicação, mecanismos efetivos e democráticos para o controle social da mídia e a participação da sociedade na construção de políticas públicas de comunicação.

\section{Os eixos temáticos}

I- Produção de Conteúdo: conteúdo nacional; produção independente; produção regional; garantia de distribuição; incentivos; tributação; financiamento; fiscalização; propriedade das entidades produtoras de conteúdo; propriedade intelectual; órgãos reguladores; competição; aspectos federativos; marco legal e regulatório.

II- Meios de Distribuição: televisão aberta; rádio; rádios e TVs comunitárias; internet; telecomunicações; bandalarga; TV por assinatura; cinema; mídia impressa; mercado editorial; sistemas público, privado e estatal; multiprogramação; tributação; financiamento; responsabilidade editorial; sistema de outorgas; fiscalização; propriedade das entidades distribuidoras de conteúdo; órgãos reguladores; aspectos federativos; infraestrutura; administração do espectro; publicidade; competição; normas e padrões; marco legal e regulatório.

III- Cidadania: Direitos e Deveres: democratização da comunicação; participação social na comunicação; liberdade de expressão; soberania nacional; inclusão social; desenvolvimento sustentável; classificação indicativa; fiscalização; órgãos reguladores; aspectos federativos; educação para a mídia; direito à comunicação; acesso à cultura e 
à educação; respeito e promoção da diversidade cultural, religiosa, étnico-racial, de gênero, orientação sexual; proteção a segmentos vulneráveis, como crianças e adolescentes; marco legal e regulatório.

\section{As propostas...}

Das 672 propostas aprovadas na Confecom, pode-se contabilizar que cerca de 144 delas abordam a questão das TIC; 84 citam a perspectiva de gênero e diversidade; 13 focam especificamente a questão da violência contra a mulher; 39 não deixam de ter relação com à violência contra a mulher; e 7 estão relacionadas à questão das TIC e da violência contra a mulher.

\section{As propostas relacionadas às TIC e Violência contra a Mulher:}

Proposta 435: Utilização dos canais de telefonia móvel para emissão de mensagens e campanhas de prevenção e promoção de saúde.

Proposta 502: Impedir a aprovação de qualquer projeto de Lei que trate a Internet e seus usuários sob o ponto de vista penal antes da discussão e aprovação de um código de direitos civis dos usuários de Internet.

Proposta 511: Aprovação de lei que defina os direitos civis nas redes digitais que inclua, mas não se limite, a garantir a todos os cidadãos: 1) o direito ao acesso à Internet sem distinção de renda, classe, credo, raça, cor, orientação sexual, sem discriminação física ou cultural; 2) o direito à acessibilidade plena, independente das dificuldades físicas ou cognitivas que possam ter; 3 ) direito de abrir suas redes e compartilhar o sinal de internet, com ou sem fio; 4) direito à comunicação não vigiada.

Proposta 523: Direito à privacidade na Internet, com regulação eficaz do hábeas data.

Proposta 568: Contra o Al-5 digital do senador Eduardo Azeredo (PSDB/MG) e por direitos civis na Internet, garantindo um ambiente legal e regulatório que respeite o caráter aberto da rede, $\mathrm{o}$ direito à privacidade e às liberdades.

Proposta 572: Garantir a Internet de forma que o uso seja livre na rede com direito à partilha de conhecimento, bens culturais e garantia da liberdade de expressão.

Proposta 650: Categorizar cada site por conteúdo, ou seja, extensões no endereço dos sítios eletrônicos tais como: xxx. para sítios pornográficos ou .inf para infantis. Além disso, cada sítio deve fornecer ao usuário a classificação etária referente ao conteúdo existente no site. De modo que os pais possam controlar de maneira mais eficaz o tipo de conteúdo acessado por seus filhos. No caso de blogs, deve constar no termo de adesão ou uso do serviço a classificação etária a 
partir da descrição do conteúdo do blog feito pelo usuário.

Leia a íntegra das propostas: www.blog.planalto.gov.br 


\section{ANEXO C - Lista de Participantes e Programa das Oficinas de Capacitação}

$1^{\text {a }}$ Oficina de capacitação - Intercâmbio Tecnológico Feminista Internet e Violência Doméstica: fazendo e intervindo - 19 e 20 de maio de 2010 - São Paulo/SP

PARTICIPANTES

\begin{tabular}{|c|c|c|c|}
\hline$N O M E$ & ENTIDADE OU GRUPO / LOCALIDADE & CONTATO/FONE & EMAIL \\
\hline Karla Maria Galdino da Silva & Cidadania Feminina - Recife/PE & (81) 3268-9582 & contato@cidadaniafeminina.org.br \\
\hline Cirlene Bezerra de Menezes & Centro das Mulheres do Cabo - Recife/PE & (81) $9988-3128$ & cirlene.menezes@gmail.com \\
\hline Joelma Cezário dos Santos & $\begin{array}{l}\text { Coturno de Vênus Associação Lésbica Feminista } \\
\text { Brasília/DF }\end{array}$ & $\begin{array}{l}\text { (61) } 8111-4250 \\
\text { (61) } 3302-4877 \\
\end{array}$ & joelma@coturnodevenus.org.br \\
\hline Panmela Castro & Anarkia Graffiteiras - Rede Nami - Rio & (21) 9784-6660 & graffiti@panmelacastro.com \\
\hline Silvia Rodrigues de Oliveira & União de Mulheres de S.Paulo - São Paulo/SP & (11) $3726-5007$ & amelinhateles@globo.com \\
\hline Sandra Regina Alves & Idem & (11) $3283-4040$ & amelinhateles@globo.com \\
\hline Maria Auxiliadora Galhano Silva & Idem & (11) 5583-1301 & galhano@uol.com.br \\
\hline Soraia Machado de Souza & Idem & $\begin{array}{l}\text { (11) } 9372-4270 \\
\text { (11) } 2991-2728 \\
\end{array}$ & soraiamsouza@hotmail.com \\
\hline Rute Cabral Barbosa & Idem & (11) $9732-4648$ & amelinhateles@globo.com \\
\hline Deise Ribeiro dos Santos & $\begin{array}{l}\text { PLPs (movimento de mulheres negras) } \\
\text { São Paulo/SP }\end{array}$ & $\begin{array}{l}\text { (11) } 2721-4587 \\
\text { (11) } 8655-9128\end{array}$ & degape@ig.com.br \\
\hline Juciara de Almeida & Idem & $\begin{array}{l}\text { (11) } 2014-5150 \\
\text { (11) } 6119-8133\end{array}$ & plpg_graca@yahoo.com \\
\hline Maria do Carmo Souza e Silva & Idem & (11) 7613-6506 & plpg_graca@yahoo.com \\
\hline Sônia Maria Pereira Nascimento & Idem & $\begin{array}{l}\text { (11) } 3333-3444 \\
\text { (11) } 9155-4244\end{array}$ & soniamp@uol.com.br \\
\hline Fortunata André Machado & Idem & (11) 8336-0569 & fortunataflor@hotmail.com \\
\hline Maria Aparecida de Lima & $\begin{array}{l}\text { Amzol (Associação de Mulheres da Zona Leste) } \\
\text { São Paulo/SP }\end{array}$ & $\begin{array}{l}\text { (11) } 2512-6398 \\
\text { (11) } 9683-1755 \\
\end{array}$ & $\begin{array}{l}\text { cidalima13@hotmail.com } \\
\text { amzol@gmail.com }\end{array}$ \\
\hline Maria José de Lima & Idem & $\begin{array}{l}\text { (11) } 2512-6398 \\
\text { (11) } 9683-1755 \\
\end{array}$ & majo1511@hotmail.com \\
\hline Adelina Maria Martins & Idem & (11) 2512-6398 & majo1511@hotmail.com \\
\hline
\end{tabular}




\begin{tabular}{|c|c|c|c|}
\hline & & (11) 9683-1755 & \\
\hline Danizi Dagmar & Idem & (11) 7297-7822 & danidagui@yahoo.com.br \\
\hline Ana Célia Minuto de Campos & $\begin{array}{l}\text { Sociedade Comunitária Fala Negão / Fala Mulher - } \\
\text { São Paulo/SP }\end{array}$ & (11) 6254-3589 & anaceliam@gmail.com \\
\hline Lucinete Minuto de Campos & Idem & (11) 7599-2908 & lucinetediferente@ig.com.br \\
\hline Lidia Grecu & Idem & (11) $2254-8200$ & centroculturaldoisoso@ig.com.br \\
\hline Lurdes Moura & Idem & (11) 7512-0358 & centroculturaldoisoso@ig.com.br \\
\hline Noemi Mota & Idem & (11) 9891-8700 & centroculturaldoisoso@ig.com.br \\
\hline Vera Vieira & Coordenadora Brasileira - OGM3 - São Paulo/SP & $\begin{array}{l}\text { (11) } 3224-9454 \\
\text { (11) } 9647-9497\end{array}$ & $\frac{\text { vera@redemulher.org.br }}{\text { vera7vieira@globo.com }}$ \\
\hline Walkíria Ferraz & Rede Mulher - Secretária OGM3 - São Paulo/SP & $\begin{array}{l}\text { (11) } 3224-9454 \\
\text { (11) } 6932-7310\end{array}$ & rdmulher@redemulher.org.br \\
\hline Nilza Iraci & Geledés - parceira OGM3 - São Paulo/SP & (11) 9584-0367 & nilraci@uol.com.br \\
\hline Jacira Vieira de Melo & Instituto Patrícia Galvão - parceira OGM3 - SP & (11) $9212-3691$ & jaciramelo@uol.com.br \\
\hline Ana Rosa Carrara & Idem - monitora & (11) 8360-4765 & anarosacarrara@gmail.com \\
\hline Cacau Freire & USP/ECA - monitora & (11) 7641-8182 & Freire.cacau@gmail.com \\
\hline
\end{tabular}




\section{PROGRAMA}

\begin{tabular}{|c|c|}
\hline $19 / 05 / 2010$ & A T I VIDA D E \\
\hline $9 h-9 h 30$ & Boas vindas; apresentação da agenda e das participantes (por Vera Vieira) \\
\hline $9 h 30-10 h 30$ & A interconexão entre gênero e TIC + exercício (por Vera Vieira) \\
\hline $10 \mathrm{~h} 30-11 \mathrm{~h} 30$ & $\begin{array}{l}\text { Mosaico (ferramentas existentes na internet e seus usos estratégicos: Blog, Twitter, Facebook, Orkut, MySpace, YouTube) + Explicações } \\
\text { sobre a utilização de ferramentas tecnológicas elementares + Exercício prático + três comentários } \\
\text { (por Cacau Freire e Ana Rosa Carrara) }\end{array}$ \\
\hline $11 \mathrm{~h} 30-11 \mathrm{~h} 45$ & Café \\
\hline $11 \mathrm{~h} 45-12 \mathrm{~h} 45$ & $\begin{array}{l}\text { Sistematização dos projetos locais (Fundo de Pequenas Iniciativas) + Discussões } \\
\text { (por Nilza Iraci) }\end{array}$ \\
\hline $12 \mathrm{~h} 45-14 \mathrm{~h} 15$ & Almoço \\
\hline $14 \mathrm{~h} 15-14 \mathrm{~h} 45$ & $\begin{array}{l}\text { Tipos de violência contra a mulher, com ênfase em violência doméstica. } \\
\text { (por Jacira Melo) }\end{array}$ \\
\hline $14 \mathrm{~h} 45-15 \mathrm{~h} 15$ & $\begin{array}{l}\text { Trabalho em cinco grupos, para criação de conteúdo e roteiro para: } \\
\text { Grupo 1: três spots } \\
\text { Grupo 2: três posters digitais } \\
\text { Grupo 3: um vídeo digital } \\
\text { Grupo 4: duas redes sociais (Blog e Orkut) } \\
\text { Grupo 5: duas redes sociais (Blog e Facebook) }\end{array}$ \\
\hline 15h15-16h15 & Apresentação dos trabalhos criados + comentários \\
\hline $16 \mathrm{~h} 15-16 \mathrm{~h} 30$ & Café \\
\hline $16 \mathrm{~h} 30-16 \mathrm{~h} 45$ & Avaliação do dia \\
\hline $20 / 05 / 2010$ & $\begin{array}{l}\text { Trabalho em cinco grupos, para viabilização digital da criação do dia anterior: } \\
\text { Grupo 1: três spots } \\
\text { Grupo 2: três posters digitais } \\
\text { Grupo 3: um vídeo digital } \\
\text { Grupo 4: duas redes sociais } \\
\text { Grupo 5: duas redes sociais }\end{array}$ \\
\hline $11 \mathrm{~h} 15-11 \mathrm{~h} 30$ & Café \\
\hline $11 \mathrm{~h} 30-12 \mathrm{~h} 45$ & Apresentação dos trabalhos em plenária \\
\hline $12 \mathrm{~h} 45-14 \mathrm{~h} 15$ & Almoço \\
\hline $14 \mathrm{~h} 15-15 \mathrm{~h} 45$ & Impressões sobre o processo de criação \\
\hline $15 \mathrm{~h} 45-16 \mathrm{~h}$ & Café \\
\hline $16 \mathrm{~h}-16 \mathrm{~h} 45$ & Plenária: resposta à pergunta $O$ que você vai levar desta oficina para potencializar o projeto local? \\
\hline
\end{tabular}


$2^{\text {a }}$ Oficina de capacitação - Intercâmbio Tecnológico Feminista

Relatos Digitais sobre Violência Doméstica - 4 e 5 de novembro de 2010 - São Paulo/SP

\section{PARTICIPANTES}

\begin{tabular}{|c|c|c|c|}
\hline NOME & ENTIDADE OU GRUPO/LOCALIDADE & CONTATO/FONE & E.Mail \\
\hline Maria Amélia Teles & União de Mulheres de São Paulo/SP. & $\begin{array}{l}\text { (11) } 3726-5007 / 3283-4040 \\
\text { (11) } 9601-4800\end{array}$ & amelinhateles@globo.com \\
\hline Anna Frank & Idem & (11) 8527-0702/8727-0702 & annafrank@uol.com.br \\
\hline Millie Thayler & Idem & (11) 6490-9557 & mthyer@igc.org \\
\hline Silvia Rodrigues de Oliveira & Idem & (11) $3726-5007$ & amelinhateles@globo.com \\
\hline Helena Alves Pinto & Idem & (11) 4555-1999 (11) 7118-1723 & plantaosocial@maua.sp.gov.br \\
\hline Ana Célia Minuto de Campos & Sociedade Fala Negão-Fala Mulher -SP. & (11) 6254-3589/6840-1223 & anaceliam@gmail.com \\
\hline Lucinete Minuto de Campos & Idem & (11) 7599-2908 & lucinetdiferent@ig.com.br \\
\hline Noeme Motta & Idem & (11) $9891-8700$ & noeme_mota@hotmail.com \\
\hline Sonia Maria do Nascimento & Promotoras Legais Populares de São Paulo & (11) 3721-4339/9155-4244 & soniamp@uol.com.br \\
\hline Juciara Almeida Souza & Idem & (11) $2014-5150 / 6119-8133$ & projulegal@gmail.com \\
\hline Mirian de Oliveira R. de Menezes & Idem & $(11) 2014-5150$ & plpgmirian@yahoo.com \\
\hline Deise Ribeiro dos Santos & Idem & (11) $2721-4587 / 8655-9128$ & degape@ig.com.br \\
\hline Maria Amélia Meireles Quadro & Idem & (11) 8797-1883/3808-6801 & mariameire58@hotmail.com \\
\hline Rita de Cássia Leite do Prado & Idem & $(11) 9555-8264$ & rita_calhambeque@hotmail.com \\
\hline Maria Aparecida dos Santos Silva & Idem & (11) 2748-8675/8176-6604 & plpgcadi@yahoo.com.br \\
\hline Rosa da Penha Silva & Idem & (11) 2156-6655/9994-5084 & plpg.rosinha@yahoo.com.br \\
\hline
\end{tabular}




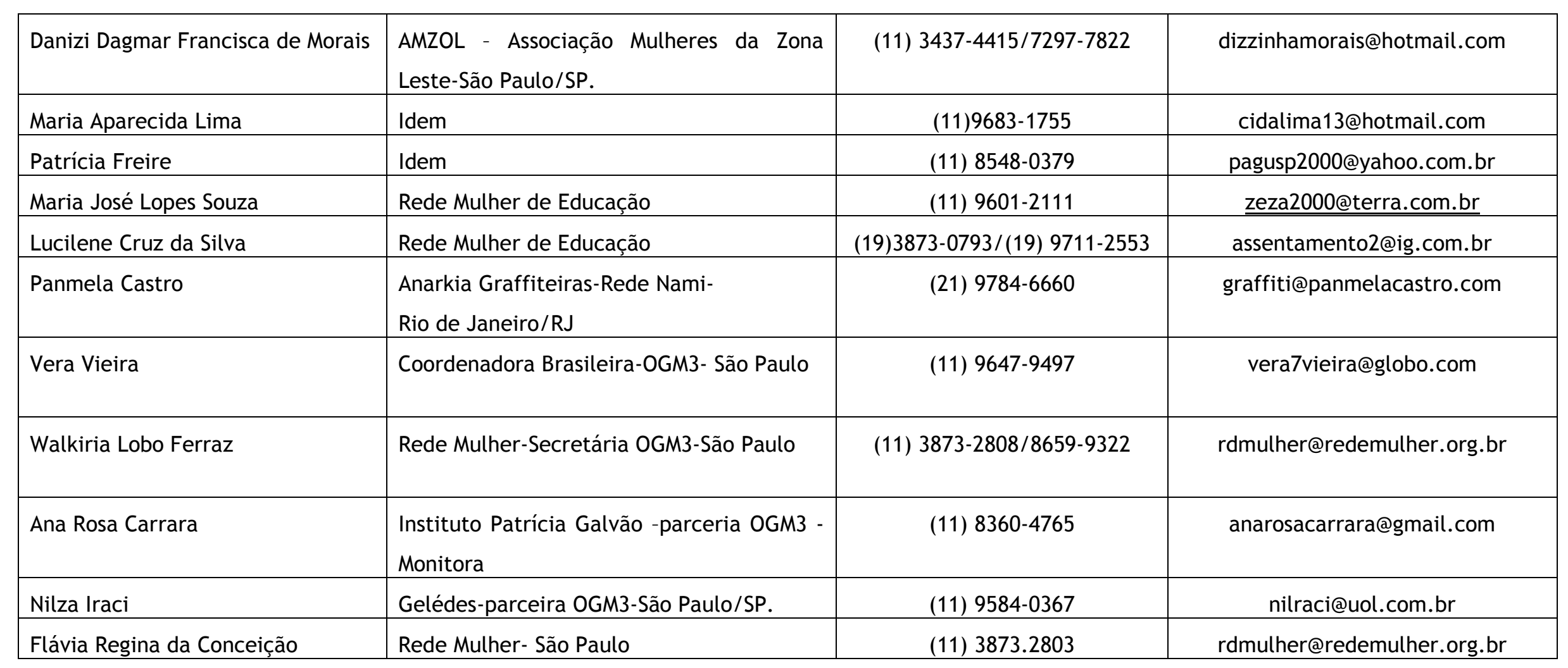




\section{PROGRAMA}

\begin{tabular}{|c|l|}
\hline $\mathbf{0 4 / 1 1 / 2 0 1 0}$ & \multicolumn{1}{c|}{ A T I V I D A D E } \\
\hline $9 \mathrm{~h}-9 \mathrm{~h} 30$ & Boas vindas; apresentação da agenda e das participantes (Vera Vieira) \\
\hline $9 \mathrm{~h} 30-10 \mathrm{~h}$ & $\begin{array}{l}\text { A inserção das redes sociais digitais nas redes de apoio à mulher em situação de violência } \\
\text { (Nilza Iraci) }\end{array}$ \\
\hline $10 \mathrm{~h}-10 \mathrm{~h} 30$ & Roteiro para relatos digitais + Tecnofobia (Vera Vieira) \\
\hline $10 \mathrm{~h} 30-10 \mathrm{~h} 45$ & Café \\
\hline $10 \mathrm{~h} 45-11 \mathrm{~h} 15$ & Utilização da Câmera Fotográfica em Gravações (Ana Rosa Carrara) \\
\hline $11 \mathrm{~h} 15-13 \mathrm{~h}$ & $\begin{array}{l}\text { Com a mão na massa: exercício prático envolvendo todas as participantes } \\
\text { (gravação de 1 minuto, edição e YouTube) - (Ana Rosa, Ana Célia e Anna Frank) }\end{array}$ \\
\hline $13 \mathrm{~h}-14 \mathrm{~h} 15$ & Almoço \\
\hline & $\begin{array}{l}\text { Trabalho em cinco grupos (roteiro, gravação, edição e YouTube) } \\
\text { Grupo 1: com depoimento de delegada da mulher } \\
\text { Grupo 2: com depoimento de profissional do CRM } \\
\text { Grupo 3: com depoimento de dupla: vítima de violência e profissional } \\
\text { Grupo 4: com depoimento de vítima de violência doméstica }\end{array}$ \\
\hline $14 \mathrm{~h} 15-17 \mathrm{~h} 30$ & \\
\hline $05 / 11 / 2010$ & Finalização dos trabalhos \\
\hline 9h $-10 \mathrm{~h}$ & Apresentação dos trabalhos em plenária + Debate \\
\hline $10 \mathrm{~h}-12 \mathrm{~h} 30$ & Compromissos com a Campanha Dominemos a Tecnologia! \\
\hline $12 \mathrm{~h} 30-13 \mathrm{~h}$ & Almoço de encerramento \\
\hline $13 \mathrm{~h}-14 \mathrm{~h}$ & \\
\hline &
\end{tabular}


ANEXO D - Atividades realizadas pelos grupos de base, no processo de multiplicação.

\begin{tabular}{|c|c|c|c|c|c|c|}
\hline $\begin{array}{c}\text { ORGANIZAÇÃO } \\
\text { E CIDADE }\end{array}$ & $\begin{array}{c}\text { MULHERES } \\
\text { BENEFICIADAS } \\
\text { DIRETAMENTE }\end{array}$ & $\begin{array}{c}\text { IDADE / } \\
\text { GRUPOS } \\
\text { ESPECÍFICOS }\end{array}$ & $\begin{array}{c}\text { MULHERES } \\
\text { BENEFICIADAS } \\
\text { INDIRETAMENTE }\end{array}$ & $\begin{array}{l}\text { TECNOLOGIA } \\
\text { UTILIZADA }\end{array}$ & $\begin{array}{c}\text { ATIVIDADES } \\
\text { E } \\
\text { PRODUTOS }\end{array}$ & $\begin{array}{l}\text { OBJETIVOS } \\
\text { E/OU } \\
\text { IMPACTOS }\end{array}$ \\
\hline $\begin{array}{c}\text { Grupo de Mulheres } \\
\text { Cidadania Feminina } \\
\text { Recife/Pernambuco } \\
\text { www.cidadaniafeminina.org.br }\end{array}$ & 20 & $\begin{array}{l}\text { - Grupo de } \\
\text { jovens, a } \\
\text { partir de } 16 \\
\text { anos. } \\
\text { - Grupo de } \\
\text { maiores de } \\
35 \text { anos. }\end{array}$ & $\begin{array}{l}\text { Projeção: } \\
5.000 \\
\text { (pela emissora } \\
\text { de rádio e } \\
\text { página web) }\end{array}$ & $\begin{array}{l}\text { - Web } 2.0 \\
\text { - Produção } \\
\text { multimídia: } \\
\text { texto, áudio } \\
\text { e vídeo. }\end{array}$ & $\begin{array}{l}\text { - } 6 \text { oficinas de } \\
\text { capacitação com } \\
\text { as jovens da rádio } \\
\text { Fala Mulher e as } \\
\text { mulheres do } \\
\text { Apitaço221. } \\
\text { - Criação e } \\
\text { divulgação de uma } \\
\text { rede virtual de } \\
\text { enfrentamento da } \\
\text { violência contra a } \\
\text { mulher. }\end{array}$ & $\begin{array}{c}\text { - Ampliação do raio de } \\
\text { alcance da rádio comunitária } \\
\text { Fala Mulher na comunidade } \\
\text { do Córrego do Euclides e } \\
\text { adjacências. } \\
\text { - Criação de um programa } \\
\text { específico sobre o } \\
\text { enfrentamento da violência } \\
\text { contra a mulher, divulgando } \\
\text { e levando informações sobre } \\
\text { os serviços de apoio à } \\
\text { mulher em situação de } \\
\text { violência, contribuindo com } \\
\text { o fortalecimento da rede de } \\
\text { enfrentamento. } \\
\text { - Troca de experiências e } \\
\text { informações entre } \\
\text { organizações que trabalham } \\
\text { o tema e/ou pessoas que } \\
\text { queiram participar da rede, } \\
\text { na perspectiva de ampliar a } \\
\text { ação do Apitaço e de ser um } \\
\text { espaço de ampliação do } \\
\text { conhecimento sobre o } \\
\text { enfrentamento da violência } \\
\text { contra a mulher. } \\
\text { - Diminuição dos índices de } \\
\text { tecnofobia feminina. }\end{array}$ \\
\hline
\end{tabular}

\footnotetext{
${ }^{221}$ O movimento Apitaço é nacionalmente conhecido = quando uma mulher está em situação de violência, o apito é utilizado por outras mulheres como instrumento de alerta e incentivo à denúncia formal e informal.
} 


\begin{tabular}{|c|c|c|c|c|c|c|}
\hline $\begin{array}{l}\text { ORGANIZAÇÃO } \\
\text { E CIDADE }\end{array}$ & $\begin{array}{l}\text { MULHERES } \\
\text { BENEFICIA } \\
\text { DAS } \\
\text { DIRETAME } \\
\text { NTE } \\
\end{array}$ & $\begin{array}{c}\text { IDADE / } \\
\text { GRUPOS } \\
\text { ESPECÍFICO } \\
\mathrm{S}\end{array}$ & $\begin{array}{c}\text { MULHERES } \\
\text { BENEFICIADAS } \\
\text { INDIRETAMENT } \\
\text { E }\end{array}$ & $\begin{array}{l}\text { TECNOLOGI } \\
\text { A UTILIZADA }\end{array}$ & $\begin{array}{l}\text { ATIVIDADES } \\
\text { E } \\
\text { PRODUTOS }\end{array}$ & $\begin{array}{l}\text { OBJETIVOS } \\
\text { E/OU } \\
\text { IMPACTOS }\end{array}$ \\
\hline $\begin{array}{c}\text { Centro das Mulheres do Cabo } \\
\text { Recife/Pernambuco } \\
\text { www.mulheresdocabo.org.br }\end{array}$ & 60 & $\begin{array}{c}\text { - Grupo de } \\
\text { jovens, a } \\
\text { partir de } 17 \\
\text { anos. } \\
\text { - Grupo de } \\
\text { maiores de } \\
30 \text { anos. }\end{array}$ & $\begin{array}{l}\text { Projeção: } \\
1 \text { milhão, } \\
\text { incluindo } \\
\text { leitoras dos } \\
\text { jornais } \\
\text { impressos, } \\
\text { ouvintes das } \\
\text { rádios e } \\
\text { mulheres que } \\
\text { acessam ao } \\
\text { site. }\end{array}$ & $\begin{array}{l}\text { - Computador } \\
\text { - Internet } \\
\text { banda-larga } \\
\text { - Web 2.0 } \\
\text { - Produçãao } \\
\text { multimídia: } \\
\text { texto, foto, } \\
\text { áudio e } \\
\text { vídeo. } \\
\text { - Telefonia } \\
\text { celular. }\end{array}$ & $\begin{array}{l}\text { - Realização de uma roda de } \\
\text { diálogo com jornalistas, } \\
\text { blogueiros/as, produtores } \\
\text { independentes e } \\
\text { comunicadores em geral do } \\
\text { Cabo de Santo Agostinho, } \\
\text { sobre a importância da } \\
\text { utilização das TIC para o } \\
\text { enfrentamento da violência } \\
\text { contras as mulheres, crianças } \\
\text { e adolescentes. } \\
\text { - Realização de um seminário } \\
\text { com a Rede de Mulheres em } \\
\text { Comunicação/PE, sobre o } \\
\text { mesmo tópico acima. } \\
\text { - Realização de um encontro } \\
\text { de sensibilização sobre a } \\
\text { violência doméstica e sexual } \\
\text { como violação dos direitos } \\
\text { humanos, com blogueiros, } \\
\text { jornalistas, radialistas e } \\
\text { comunicadores que atuam na } \\
\text { Região Metropolitana de } \\
\text { Recife. } \\
\text { - Produção de pautas sobre o } \\
\text { contexto da violência } \\
\text { doméstica e sexual praticada } \\
\text { contra mulheres, crianças e } \\
\text { adolescentes por ocasião do } 25 \\
\text { de Novembro - Dia de Luta } \\
\text { Contra a Violência Doméstica e } \\
\text { Sexista e encaminhar para a }\end{array}$ & $\begin{array}{l}\text { - Promover a inclusão } \\
\text { de temas relacionados } \\
\text { à violência doméstica } \\
\text { e sexual em sites, } \\
\text { blogs e veículos de } \\
\text { comunicação do Cabo } \\
\text { de Santo Agostinho, } \\
\text { redes de comunicação } \\
\text { feminista e redes } \\
\text { sociais independentes } \\
\text { que têm como } \\
\text { princípio a defesa dos } \\
\text { direitos humanos. } \\
\text { - Ampliar o debate } \\
\text { sobre a importância } \\
\text { da prevenção e do } \\
\text { enfrentamento à } \\
\text { violência doméstica e } \\
\text { sexual praticada } \\
\text { contra mulheres, } \\
\text { crianças e } \\
\text { adolescentes, entre } \\
\text { produtores de mídia } \\
\text { independentes que } \\
\text { utilizam as TIC como } \\
\text { ferramentas de } \\
\text { trabalho, no Cabo de } \\
\text { Santo Agostinho e } \\
\text { Região Metropolitana } \\
\text { do Recife. } \\
\text { - Pautar o tema da } \\
\text { violência doméstica e }\end{array}$ \\
\hline
\end{tabular}




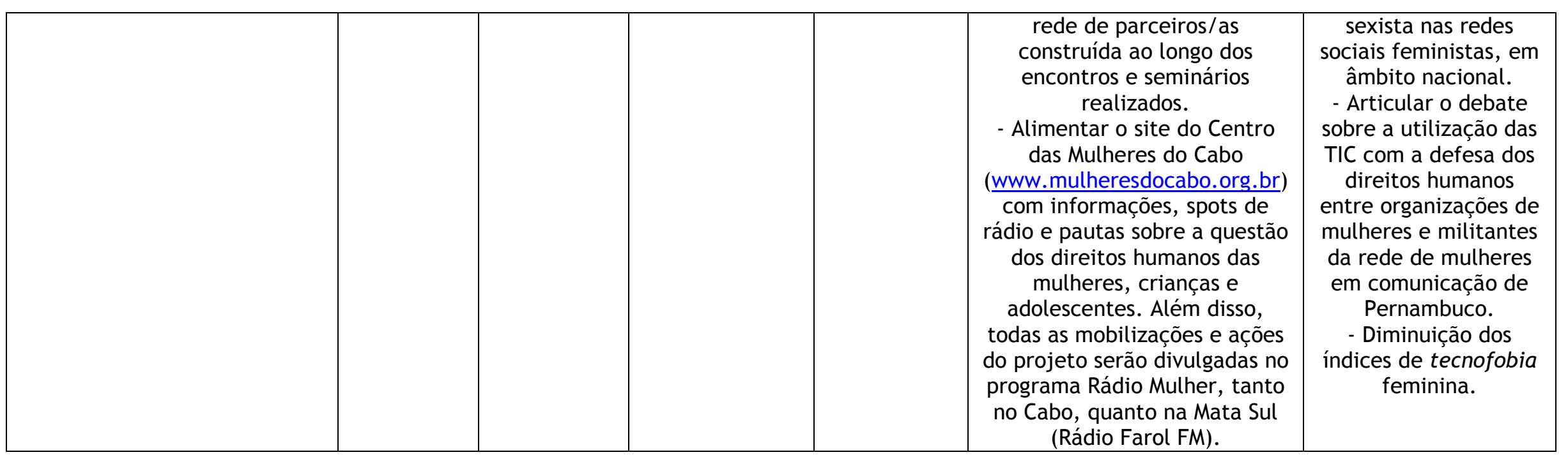




\begin{tabular}{|c|c|c|c|c|c|c|}
\hline $\begin{array}{c}\text { ORGANIZAÇÃO } \\
\text { E CIDADE }\end{array}$ & $\begin{array}{c}\text { MULHERES } \\
\text { BENEFICIADAS } \\
\text { DIRETAMENTE }\end{array}$ & $\begin{array}{c}\text { IDADE / } \\
\text { GRUPOS } \\
\text { ESPECÍFICOS }\end{array}$ & $\begin{array}{c}\text { MULHERES } \\
\text { BENEFICIADAS } \\
\text { INDIRETAMENTE }\end{array}$ & $\begin{array}{l}\text { TECNOLOGIA } \\
\text { UTILIZADA }\end{array}$ & $\begin{array}{l}\text { ATIVIDADES } \\
\text { E } \\
\text { PRODUTOS }\end{array}$ & $\begin{array}{l}\text { OBJETIVOS } \\
\text { E/OU } \\
\text { IMPACTOS }\end{array}$ \\
\hline $\begin{array}{c}\text { Associação Lésbica } \\
\text { Feminista de Brasília - } \\
\text { Coturno de Vênus } \\
\text { Brasília/DF } \\
\text { www.coturnodevenus.org.br }\end{array}$ & 30 & $\begin{array}{l}\text { Jovens entre } \\
18 \text { e } 30 \text { anos }\end{array}$ & $\begin{array}{c}\text { Projeção: } \\
5.000\end{array}$ & $\begin{array}{l}\text { - Computador } \\
\text { - Internet } \\
\text { banda-larga } \\
\text { - Web 2.0 } \\
\text { - Produção } \\
\text { multimídia: } \\
\text { texto, foto, } \\
\text { áudio e } \\
\text { vídeo. }\end{array}$ & $\begin{array}{l}\text { - Construção de } \\
\text { página web } \\
\text { - Encontro "Diálogos } \\
\text { sobre a violência" } \\
\text { - Encontro "Diálogos } \\
\text { sobre violência - } \\
\text { lesbofobia" } \\
\text { - Fórum virtual - } \\
\text { Diálogos sobre a } \\
\text { violência }\end{array}$ & $\begin{array}{l}\text { - Construir e compartilhar } \\
\text { diagnósticos sobre a } \\
\text { violência contra as } \\
\text { mulheres, lésbicas e } \\
\text { bissexuais. } \\
\text { - Trocar informações úteis } \\
\text { ao maior número de } \\
\text { mulheres que acessem a } \\
\text { página web. } \\
\text { - Auxiliar, de forma } \\
\text { propositiva, a } \\
\text { transformação social } \\
\text { proposta pelas mulheres e } \\
\text { seus movimentos. } \\
\text { - Diminuição dos índices de } \\
\text { tecnofobia feminina. }\end{array}$ \\
\hline
\end{tabular}




\begin{tabular}{|c|c|c|c|c|c|c|}
\hline $\begin{array}{c}\text { ORGANIZAÇÃO } \\
\text { E CIDADE }\end{array}$ & $\begin{array}{c}\text { MULHERES } \\
\text { BENEFICIADAS } \\
\text { DIRETAMENTE }\end{array}$ & $\begin{array}{c}\text { IDADE / } \\
\text { GRUPOS } \\
\text { ESPECÍFICOS }\end{array}$ & $\begin{array}{c}\text { MULHERES } \\
\text { BENEFICIADAS } \\
\text { INDIRETAMENTE }\end{array}$ & $\begin{array}{c}\text { TECNOLOGIA } \\
\text { UTILIZADA }\end{array}$ & $\begin{array}{c}\text { ATIVIDADES } \\
\text { E } \\
\text { PRODUTOS }\end{array}$ & $\begin{array}{l}\text { OBJETIVOS } \\
\text { E/OU } \\
\text { IMPACTOS }\end{array}$ \\
\hline $\begin{array}{c}\text { Nami - Rede } \\
\text { Feminista de Arte } \\
\text { Urbana } \\
\text { Rio de Janeiro/RJ } \\
\text { www.redenami.com }\end{array}$ & 100 & $\begin{array}{l}\text { Jovens entre } \\
20 \text { e } 30 \text { anos }\end{array}$ & $\begin{array}{c}\text { Projeção: } \\
5.000\end{array}$ & $\begin{array}{c}\text { - Computador } \\
\text { - Internet } \\
\text { banda-larga } \\
\text { - Web 2.0 } \\
\text { - Produçãao } \\
\text { multimídia: } \\
\text { texto, foto, } \\
\text { áudio, e } \\
\text { vídeo. } \\
\text { - Telefonia } \\
\text { celular }\end{array}$ & $\begin{array}{c}\text { - Curso sobre "A violência } \\
\text { contra as mulheres e a Lei } \\
\text { Maria da Penha". } \\
\text { - Debate sobre novas } \\
\text { tecnologias da informação } \\
\text { e comunicação na arte. } \\
\text { - Palestra sobre a história } \\
\text { do movimento de } \\
\text { mulheres no grafite } \\
\text { brasileiro. } \\
\text { - Duas sessões de pintura } \\
\text { coletiva, mutirão de } \\
\text { grafite na Comunidade do } \\
\text { Sapo e seminário. }\end{array}$ & $\begin{array}{l}\text { - Fortalecimento da Rede Nami } \\
\text { com capacitação profunda em } \\
\text { violência de gênero, } \\
\text { principalmente no que } \\
\text { concerne à Lei Maria da Penha. } \\
\text { - Criação de uma biblioteca } \\
\text { virtual com conteúdo } \\
\text { informativo sobre violência de } \\
\text { gênero, direitos da mulher, } \\
\text { arte e tecnologia. } \\
\text { - Conscientização sobre a Lei } \\
\text { Maria da Penha, por parte da } \\
\text { população em geral, em função } \\
\text { do Mural Público temático. } \\
\text { - Diminuição dos índices de } \\
\text { tecnofobia feminina. }\end{array}$ \\
\hline
\end{tabular}




\begin{tabular}{|c|c|c|c|c|c|c|}
\hline $\begin{array}{c}\text { ORGANIZAÇÃO } \\
\text { E CIDADE }\end{array}$ & $\begin{array}{c}\text { MULHERES } \\
\text { BENEFICIADAS } \\
\text { DIRETAMENTE }\end{array}$ & $\begin{array}{c}\text { IDADE / } \\
\text { GRUPOS } \\
\text { ESPECÍFICOS }\end{array}$ & $\begin{array}{c}\text { MULHERES } \\
\text { BENEFICIADAS } \\
\text { INDIRETAMENTE }\end{array}$ & $\begin{array}{l}\text { TECNOLOGIA } \\
\text { UTILIZADA }\end{array}$ & $\begin{array}{l}\text { ATIVIDADES } \\
\text { E } \\
\text { PRODUTOS }\end{array}$ & $\begin{array}{l}\text { OBJETIVOS } \\
\text { E/OU } \\
\text { IMPACTOS }\end{array}$ \\
\hline $\begin{array}{l}\text { Promotoras Legais } \\
\text { Populares (PLPs) - } \\
\text { mulheres negras - } \\
\text { Zona Leste } \\
\text { São Paulo/SP } \\
\\
\text { www.geledes.org.br }\end{array}$ & 37 & $\begin{array}{l}\text { Jovens entre } \\
20 \text { e } 30 \text { anos } \\
\text { Mulheres de } \\
31 \text { a } 70 \text { anos }\end{array}$ & $\begin{array}{l}\text { Projeção: } \\
5.000\end{array}$ & $\begin{array}{l}\text { - Computador } \\
\text { - Internet } \\
\text { Banda-larga } \\
\text { - Web 2.0 } \\
\text { - Produção } \\
\text { multimídia: } \\
\text { texto, foto, } \\
\text { áudio, e } \\
\text { vídeo. } \\
\text { - Data-show }\end{array}$ & $\begin{array}{c}\text { - Reuniões de criação e } \\
\text { estudo da temática da } \\
\text { violência contra a mulher } \\
\text { e as TIC. } \\
\text { - Produção de um vídeo } \\
\text { sobre a atuação das } \\
\text { Promotoras Legais } \\
\text { Populares (PLPs) junto ao } \\
\text { Hospital Geral de São } \\
\text { Mateus, retratando o } \\
\text { cotidiano de atendimento } \\
\text { às mulheres vítimas da } \\
\text { violência e sua } \\
\text { contribuição no } \\
\text { enfrentamento à violência } \\
\text { doméstica. Contará com a } \\
\text { participação das usuárias e } \\
\text { funcionárias da Casa de } \\
\text { Referência no } \\
\text { Atendimento às Mulheres } \\
\text { em Situação de Violência e } \\
\text { das PLPs. } \\
\text { - Produção de } 20 \\
\text { exemplares de CD com o } \\
\text { vídeo, para disseminação } \\
\text { de seu conteúdo. } \\
\text { - Apresentação do vídeo e } \\
\text { discussão, no Núcleo das } \\
\text { PLPs do Hospital de São } \\
\text { Mateus, nas reuniões da } \\
\text { Coordenadoria de Saúde } \\
\text { onde atual duas PLPs no }\end{array}$ & $\begin{array}{c}\text { - Reflexão e conscientização sobre } \\
\text { a violência contra a mulher e os } \\
\text { danos psicossociais para a pessoa } \\
\text { e a comunidade, na perspectiva } \\
\text { de gênero. } \\
\text { - Divulgação do trabalho das } \\
\text { Promotoras Legais Populares no } \\
\text { atendimento às mulheres vítimas } \\
\text { de violência, visando o } \\
\text { enfrentamento da questão. } \\
\text { - Conscientização e capacitação } \\
\text { de mulheres e adolescentes em } \\
\text { geral, por meio da } \\
\text { disponibilização do vídeo na } \\
\text { internet. } \\
\text { - Conscientização e } \\
\text { implementação de políticas } \\
\text { públicas voltadas para a violência } \\
\text { doméstica cometida por filhos } \\
\text { dependentes químicos, } \\
\text { principalmente às mulheres mais } \\
\text { idosas. } \\
\text { - Diminuição dos índices de } \\
\text { tecnofobia feminina. }\end{array}$ \\
\hline
\end{tabular}




\begin{tabular}{|l|l|l|l|l|}
\hline & & & & $\begin{array}{c}\text { Serviço de Saúde da } \\
\text { Família da Cidade de } \\
\text { Tiradentes, nas Casas de } \\
\text { Referência de atendimento } \\
\text { às Mulheres dos bairros de } \\
\text { São Mateus, Cidade } \\
\text { Tiradentes e Guaianazes. }\end{array}$ \\
\hline
\end{tabular}

Links

http://www.youtube.com/watch?v=bIfu1vr_RC4

http://www.youtube.com/watch?v=aw_RBV7KRJc

http://www.youtube.com/watch?v=nDfu_kxnZFc 


\begin{tabular}{|c|c|c|c|c|c|c|}
\hline $\begin{array}{c}\text { ORGANIZAÇÃO } \\
\text { E CIDADE }\end{array}$ & $\begin{array}{c}\text { MULHERES } \\
\text { BENEFICIADAS } \\
\text { DIRETAMENTE }\end{array}$ & $\begin{array}{c}\text { IDADE / } \\
\text { GRUPOS } \\
\text { ESPECÍFICOS }\end{array}$ & $\begin{array}{c}\text { MULHERES } \\
\text { BENEFICIADAS } \\
\text { INDIRETAMENTE }\end{array}$ & $\begin{array}{c}\text { TECNOLOGIA } \\
\text { UTILIZADA }\end{array}$ & $\begin{array}{c}\text { ATIVIDADES } \\
\text { E } \\
\text { PRODUTOS }\end{array}$ & $\begin{array}{l}\text { OBJETIVOS } \\
\text { E/OU } \\
\text { IMPACTOS }\end{array}$ \\
\hline 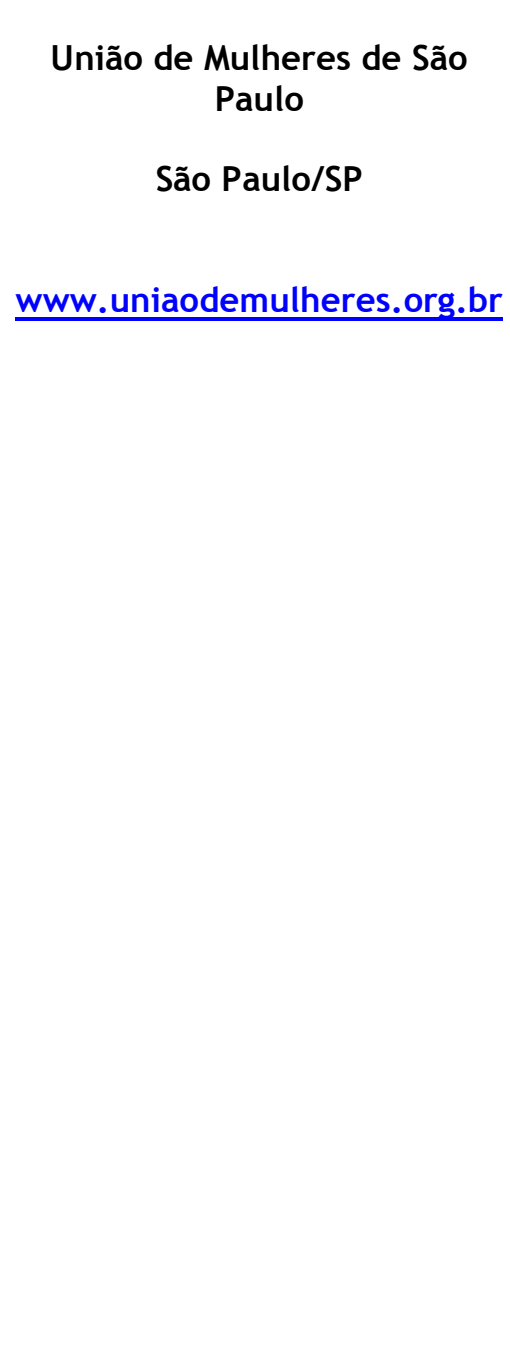 & 40 & $\begin{array}{l}\text { Mulheres } \\
\text { adultas } \\
\text { entre } 32 \text { e } \\
60 \text { anos. }\end{array}$ & $\begin{array}{c}\text { Projeção: } \\
5.000\end{array}$ & $\begin{array}{l}\text { - Computador } \\
\text { - Internet } \\
\text { banda-larga } \\
\text { - Web 2.0 } \\
\text { - Produção } \\
\text { multimídia: } \\
\text { texto, foto, } \\
\text { áudio, e } \\
\text { vídeo. } \\
\text { - Telefonia } \\
\text { celular }\end{array}$ & $\begin{array}{l}\text { - Oficina } \\
\text { “Aprendendo a usar } \\
\text { a internet” (abrir } \\
\text { conta, enviar e } \\
\text { receber emails, } \\
\text { encaminhar com } \\
\text { cópia oculta, etc). } \\
\text { - Oficina "Usar a } \\
\text { internet para } \\
\text { prevenir a violência } \\
\text { contra a mulehr” } \\
\text { (revisão e como usar } \\
\text { a internet, criar } \\
\text { grupos de emails } \\
\text { colocando } \\
\text { organizações e } \\
\text { pessoas } \\
\text { individualmente para } \\
\text { atuar na prevenção } \\
\text { da violência). } \\
\text { - Oficina "Explorando } \\
\text { o espaço virtual” } \\
\text { (buscar e selecionar } \\
\text { informações, } \\
\text { imagens, músicas e } \\
\text { pequenos filmes para } \\
\text { encaminhar aos } \\
\text { grupos de emails). } \\
\text { Oficina “Utilizando o } \\
\text { celular” (para fazer } \\
\text { fotos, gravar vídeos } \\
\text { e comunicar/ } \\
\text { denunciar aos } \\
\text { serviços públicos/ }\end{array}$ & $\begin{array}{c}\text { - Reforço de conhecimentos } \\
\text { sobre relações de } \\
\text { desigualdades de gênero e as } \\
\text { formas de uso das TIC para o } \\
\text { enfrentamento e a } \\
\text { erradicação da violência } \\
\text { contra a mulher. } \\
\text { - Aprendizado básico para } \\
\text { identificar situaç̃̃es de } \\
\text { assédio sexual, assédio moral, } \\
\text { violência sexual, estupro, } \\
\text { legislaçãa sobre violência } \\
\text { doméstica e familiar. } \\
\text { - Realização de plantões com } \\
\text { o uso da internet em } \\
\text { organizaçõos, para } \\
\text { informações e } \\
\text { encaminhamentos de casos. } \\
\text { - Realização de contatos e } \\
\text { encaminhamentos de casos } \\
\text { utilizado-se lan-houses ou } \\
\text { outro local com acesso a } \\
\text { computador e internet. } \\
\text { - Encaminhamento de abaixo- } \\
\text { assinados contra a violência à } \\
\text { mulher. } \\
\text { - Realização da campanha em } \\
\text { prol da abertura durante } 24 h \\
\text { das delegacias da mulher. } \\
\text { - Diminuição dos índices de } \\
\text { tecnofobia feminina. }\end{array}$ \\
\hline
\end{tabular}




\begin{tabular}{|l|l|l|l|}
\hline & & & \\
& & & $\begin{array}{c}\text { polícia, sobre } \\
\text { situações de } \\
\text { violência contra a } \\
\text { mulher. } \\
\text { - Realização de } \\
\text { pequenos encontros } \\
\text { bimensais para } \\
\text { trocar experiências } \\
\text { sobre o uso das TIC } \\
\text { no trabalho de } \\
\text { prevenção da } \\
\text { violência contra a } \\
\text { mulher. }\end{array}$ \\
\hline
\end{tabular}




\begin{tabular}{|c|c|c|c|c|c|c|}
\hline $\begin{array}{c}\text { ORGANIZAÇÃO } \\
\text { E CIDADE }\end{array}$ & $\begin{array}{c}\text { MULHERES } \\
\text { BENEFICIADAS } \\
\text { DIRETAMENTE }\end{array}$ & $\begin{array}{c}\text { IDADE / } \\
\text { GRUPOS } \\
\text { ESPECÍFICOS }\end{array}$ & $\begin{array}{c}\text { MULHERES } \\
\text { BENEFICIADAS } \\
\text { INDIRETAMENTE }\end{array}$ & $\begin{array}{c}\text { TECNOLOGIA } \\
\text { UTILIZADA }\end{array}$ & $\begin{array}{c}\text { ATIVIDADES } \\
\text { E } \\
\text { PRODUTOS } \\
\end{array}$ & $\begin{array}{l}\text { OBJETIVOS } \\
\text { E/OU } \\
\text { IMPACTOS }\end{array}$ \\
\hline $\begin{array}{l}\text { Sociedade Comunitária Ecológica Cultural } \\
\text { e Escola de Samba "Fala Negão / } \\
\text { Fala Mulher" } \\
\text { São Paulo/SP } \\
\text { http://falanegaofalamulher.blogspot.com/ }\end{array}$ & 47 & $\begin{array}{l}\text { Jovens entre } \\
18 \text { e } 30 \text { anos } \\
\text { Mulheres de } \\
31 \text { a } 60 \text { anos } \\
2 \text { homens }\end{array}$ & $\begin{array}{c}\text { Projeção: } \\
5.000\end{array}$ & $\begin{array}{c}\text { - Computador } \\
\text { - Internet } \\
\text { banda-larga } \\
\text { - Web 2.0 } \\
\text { - Produção } \\
\text { multimídia: } \\
\text { texto, foto, } \\
\text { áudio e } \\
\text { vídeo. } \\
\text { - Telefonia } \\
\text { celular }\end{array}$ & $\begin{array}{c}\text { - Realização } \\
\text { de três } \\
\text { oficinas sobre } \\
\text { "A } \\
\text { importância } \\
\text { da tecnologia } \\
\text { no combate à } \\
\text { violência } \\
\text { doméstica", } \\
\text { como foco } \\
\text { em “Cuidar } \\
\text { de si e viver } \\
\text { bem”. } \\
\text { - Produção de } \\
500 \text { fotos. } \\
\text { - Produção de } \\
3 \text { vídeos } \\
\text { - Distribuição } \\
\text { das } \\
\text { informações } \\
\text { em redes } \\
\text { sociais e } \\
\text { blogs. }\end{array}$ & $\begin{array}{l}\text { - Disseminação da } \\
\text { cultura de paz e } \\
\text { aumento da } \\
\text { autoestima. } \\
\text { - Aprendizagem de } \\
\text { métodos de } \\
\text { comunicação e de } \\
\text { liderança, com } \\
\text { enfoque nos conflitos } \\
\text { cotidianos. } \\
\text { - Multiplicação das } \\
\text { técnicas através das } \\
\text { redes sociais. } \\
\text { - Diminuição dos } \\
\text { índices de tecnofobia } \\
\text { feminina. }\end{array}$ \\
\hline
\end{tabular}

Links extras:

Canal do Fala Negão/Fala Mulher no Youtube : falanegaofalamulher

http://www.youtube.com/watch?v=lavC5cSDxi8

http://www.youtube.com/watch?v=-77BbplEH Q\&feature=related

Fotos : https://picasaweb.google.com/111517491867177396500/FotosCasaViviane\# 
https://picasaweb.google.com/111517491867177396500/CapacitarEMostrarNoFalaNegaoFalaMulher\#

https://picasaweb.google.com/111517491867177396500/CursoMidiasDigitais\#

https://picasaweb.google.com/111517491867177396500/CasaCidinhaKopcap\# 


\begin{tabular}{|c|c|c|c|c|c|c|}
\hline $\begin{array}{c}\text { ORGANIZAÇÃO } \\
\text { E CIDADE }\end{array}$ & $\begin{array}{c}\text { MULHERES } \\
\text { BENEFICIADAS } \\
\text { DIRETAMENTE }\end{array}$ & $\begin{array}{c}\text { IDADE / } \\
\text { GRUPOS } \\
\text { ESPECÍFICOS }\end{array}$ & $\begin{array}{c}\text { MULHERES } \\
\text { BENEFICIADAS } \\
\text { INDIRETAMENTE }\end{array}$ & $\begin{array}{c}\text { TECNOLOGIA } \\
\text { UTILIZADA }\end{array}$ & $\begin{array}{c}\text { ATIVIDADES } \\
\text { E } \\
\text { PRODUTOS }\end{array}$ & $\begin{array}{l}\text { OBJETIVOS } \\
\text { E/OU } \\
\text { IMPACTOS }\end{array}$ \\
\hline $\begin{array}{c}\text { AMZOL - } \\
\text { Associação de } \\
\text { Mulheres da Zona } \\
\text { Leste } \\
\text { São Paulo/SP } \\
\text { http://mulheres- } \\
\text { tics.blogspot.com }\end{array}$ & 20 & $\begin{array}{l}\text { Jovens entre } \\
18 \text { e } 30 \text { anos } \\
\text { Mulheres de } \\
31 \text { a } 60 \text { anos }\end{array}$ & $\begin{array}{c}\text { Projeção: } \\
5.000\end{array}$ & $\begin{array}{c}\text { - Computador } \\
\text { - Internet } \\
\text { banda-larga } \\
\text { - Web 2.0 } \\
\text { - Produçãoo } \\
\text { multimídia: } \\
\text { texto, foto, } \\
\text { áudio e } \\
\text { vídeo. } \\
\text { - Telefonia } \\
\text { celular }\end{array}$ & $\begin{array}{l}\text { - Seleção e organização de } \\
\text { materiais do acervo, } \\
\text { pesquisa e preparação do } \\
\text { projeto de blog. } \\
\text { - Digitalização de materiais } \\
\text { e pesquisa de materiais via } \\
\text { internet. } \\
\text { - Sessões de trabalho online } \\
\text { (troca de informações e } \\
\text { documentos para } \\
\text { composição do blog) } \\
\text { - Realização de oficina } \\
\text { intitulada "Mulheres na } \\
\text { Rede Social Virtual contra a } \\
\text { Violência". }\end{array}$ & $\begin{array}{c}\text { - Aumento da participação das } \\
\text { mulheres no intercâmbio de } \\
\text { informações sobre violência } \\
\text { doméstica. } \\
\text { - Alcance de um número maior } \\
\text { de mulheres através do blog, } \\
\text { visando ampliar a rede para } \\
\text { erradicar a violência contra a } \\
\text { mulher. } \\
\text { - Diminuição dos índices de } \\
\text { tecnofobia feminina. }\end{array}$ \\
\hline
\end{tabular}


ANEXO E - Cartaz e folder do projeto Mulheres e Homens pela Paz e contra a Violência Doméstica

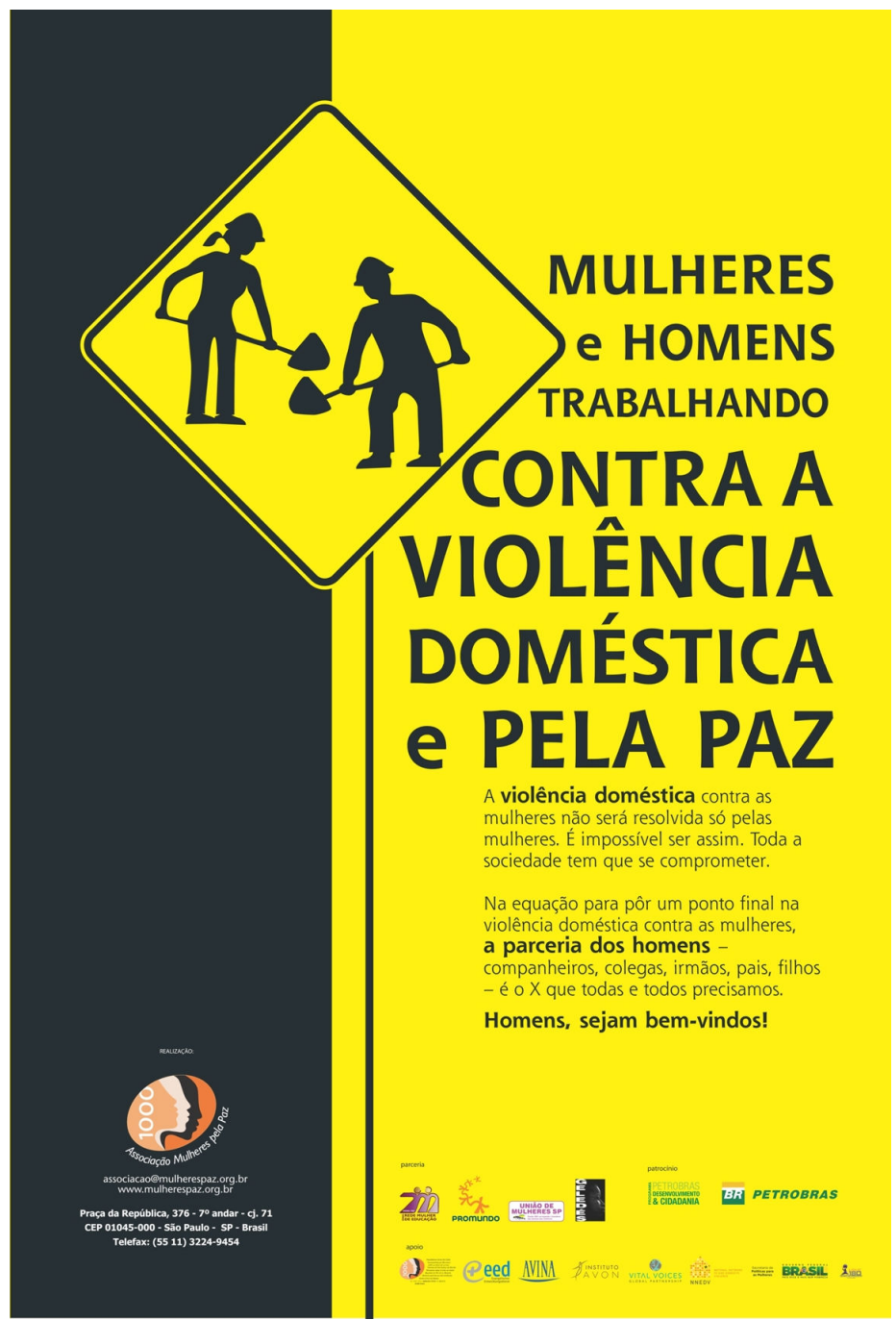




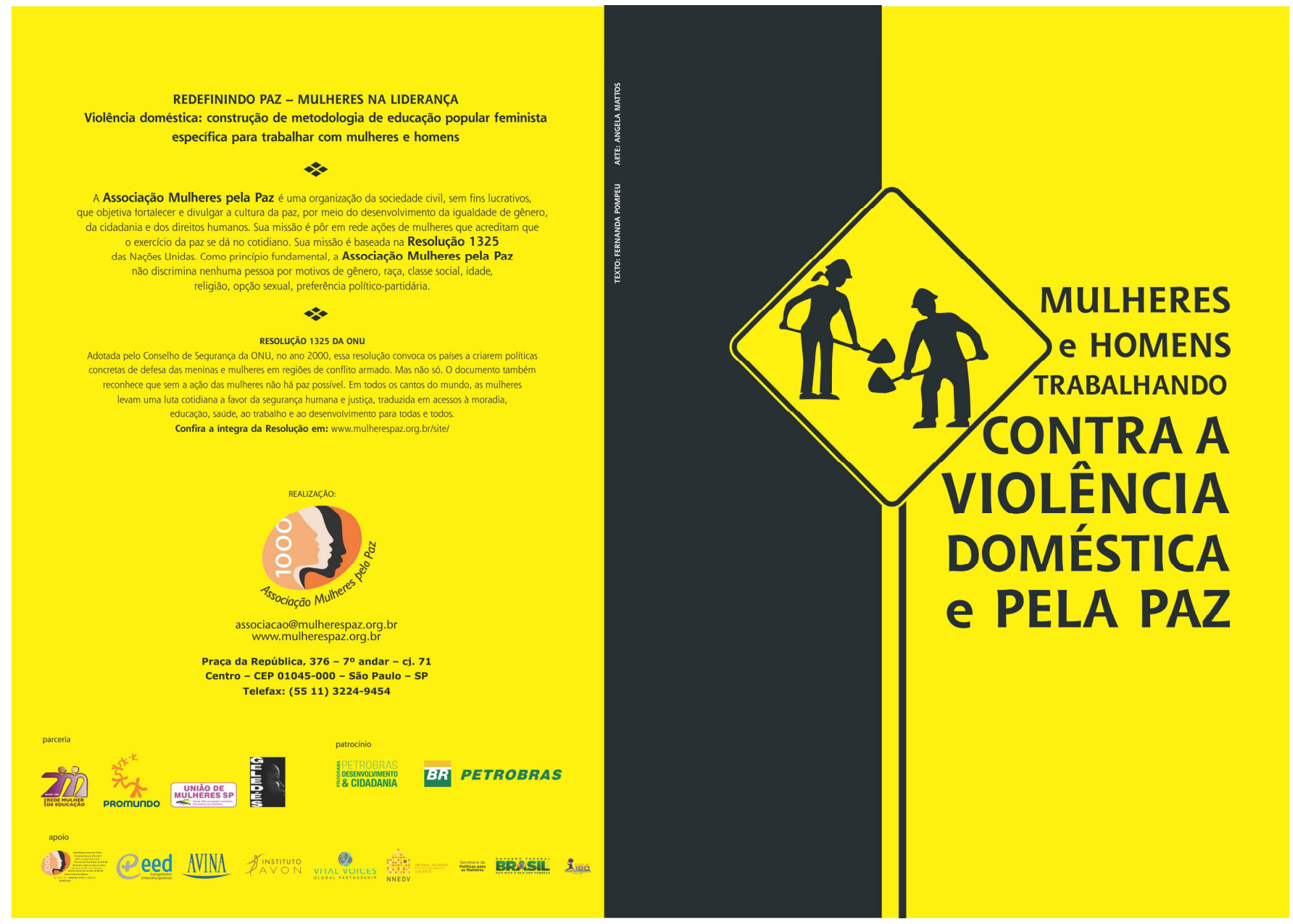




\section{O PROBLEMA}

0 planeta gira cada vez mais rápido com as infor- impunes. Na maioria das vezes, o comportamento mord

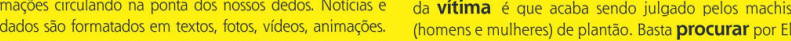
Notebooks, celulares, tablets se massificam. Tenolog

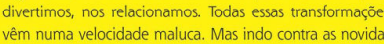
des tem um problema que permancece constan

o que acontecec com essa sociedade que, na segunda década
do século XXI, tolera a violência doméstica contra as mulheres? Pois, se a violência contra cirinças, de grande parte da sociedade, o mesmo năo ocorre Mulheres sofrem violência - fisica e moral - por parte de ainda tem vida o o ditado popularr: "em briga de marido namorados, noivos, maridos. Mesmo depois da seps de violência estão em párse dus wolvinento e pobres. Elas podem ser negras ou branc. boa renda ou renda minima. Podem ser evangétites católicas, espíitiss, candomblezerias etc. Ou não
crença nenhuma. Em média, una em cada trés mulhers

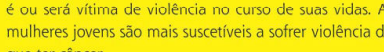

\section{A ORIGEM}

No mundo interio, com variacóes de intensidade, as mu-
Iheres estão em desvantagem com relacăo e empresarial. Da Suécia a Bangladest, elas ganham Segundo horas por semana com trabalhos domésticos, enquanto aqueles que simplesmente gastam hora nenhuma, deixando o rojầo doméstico queimar nas mãos da patrimonial, da destruiçăo de documentos à perda No Brasil, o quadro é grave e os números são de A A imensa maioria das mulheres agredidas tem como algozes homens com quem elas mantềm ou mantinha
relaçós de intimidade. Só em Pernambuco, Sendo que todos os outros
indices altos de femicidio. Há também os casos que chegam na grande midia. Recese temente, vimos, com riqueza de detalhes, as histór
trágicas de Eloá Cristina Pimentel, 15 anos.

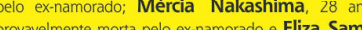
dio, 25 anos, cujo Bruno, famoso goleiro do lamengo. Aol ado dessas vitimas, há milhares de o vulheres, no pals e no mundo, sorennd não se tornam manchetes. Na miso ria das vezes, seus agressores seguem liveres
Sáo também as mulheres que carregam a banderia da paz.
Năo de forma simbolica. Mas no dia a dia. Elas sáo a maioria nos movimentios por saude, moradia, educcaçăo. A mu como justiça
humana. Fazem is
que seria
de lazer

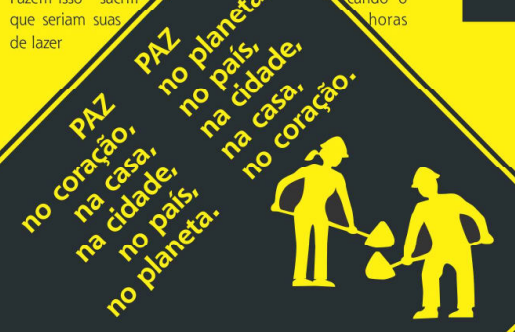

A tradiçăo cultural não é muito amiga das mulheres. cuidar, perdoar e servir ao companheiro ainda

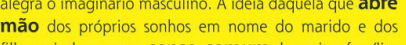
Na ponta complementar, há a ideia do homem coman. dante, diretor, chefe, mandatário. Ele, senhor do mundo. Ela, senhora da casa. Ele na vanguarda das decisöes. Ela na retaguarda, indo a rebo
das necessidades e desejos dele.

Essas expressöes dos papéis feminino e masculino săo chamadas de relaçoes de gènero. Săb constru-
cōes sociais alimentadas pela cultura, que permeiam geraçoes e geraçoes. Mas nao se trata apenas de papeís sociais diferentes. Se trata de uma robusta desi-
gualdade, na qual eles exercem uma relaçăo de dominação sobre elas. Também é un una relaçăa injusta, na medida que $\mathrm{O}$ contrato social sempre deu aos homens muito mais oportunidades. Basta lembrar que o Banco do Brasil, tundado em 1808 , so
abriu concurso para as mulheres 101 anos depois, em 1969!

É claro que não estamos afirmando que TODOS os homens sao dominadores e violentos. Estamos
alando de um significativo número de homens que jáa uararam algum tipo de violência contra suas parcei-
ras. Nấo estamos afirmando que TODAS as mulheres são dominadas e submetidas à violência. Estamos falando de um significativo numero de

\section{O DESAFIO}

erradicar a violencia doméstica conta

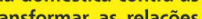
de gênero teimosamente establecidas. É preciso trazer não basta respeitar a sua mulher. É neces. sário, também, que eles tentem convencer os outros
homens a fazer a mesmo. É O que chamamos de influência cultural um homem conversa
com outro, que conversa com outro, que conversa com outro.
Transformando o ditado popular: em briga de marido e mulher se mete a colher.
Ther

duçção popular feminista, baseada em dologias para engajar os homens, jovens e adultos, na superaçao

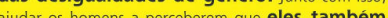
saem perdendo com a imposição social de is de genero.

saem percendo quando são educados para a

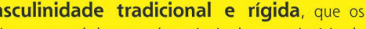
Wher e dos filhos. Tal obrigação, cada vez mais imposter de curninit, embrutece sua sensibilidade tolhe sua liberdade de ser como quiser ser, fora homens devem e podem ser vistos como parDe these familiores. Tarceiros em uma relaçăo sem vendores nem perdedores. Há exemplos de açoes mens se posicionam contra a violência

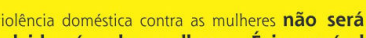
ser assim. Toda a socidade tem aye se compromel ter. O Estado tem que agir, como age quando faz valer Lei Maria da Penha - que responsabiliza e pune agressores domésticos. Tambem tem que criar politi-
cas públicas que favorecam uma melhor interação entre mulheres e homens.

mesquecer que as mídias - tradicionais e digitais

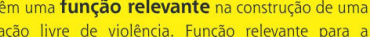
formaçăo de uma massa crítica dentro da sociedade. ponténdos contribuem para legis informais. Seus Na equaçāo para pôr um ponto final na violéncia omens, sejam bem-vindos! Homens, sejam bem-vindos 